UNIVERSIDADE DE SÃO PAULO

FACULDADE DE FILOSOFIA, CIÊNCIAS E LETRAS DE RIBEIRÃO PRETO PROGRAMA DE PÓS-GRADUAÇÃO EM EDUCAÇÃO

\title{
ENSINO FUNDAMENTAL DE NOVE ANOS: UMA AMPLIAÇÃ̃O DE DIREITOS?
}

PAULA DANIELE FERRARESI

Ribeirão Preto - SP

2015 
UNIVERSIDADE DE SÃO PAULO

FACULDADE DE FILOSOFIA, CIÊNCIAS E LETRAS DE RIBEIRÃO PRETO PROGRAMA DE PÓS-GRADUAÇÃO EM EDUCAÇÃO

PAULA DANIELE FERRARESI

\title{
ENSINO FUNDAMENTAL DE NOVE ANOS: UMA AMPLIAÇÃO DE DIREITOS?
}

\author{
Versão corrigida
}

Dissertação apresentada à Faculdade de Filosofia, Ciências e Letras de Ribeirão Preto, Universidade de São Paulo - USP, como requisito para a obtenção do título de Mestre em Educação, Área: Políticas Públicas e Organização do Trabalho Educacional.

Orientador: José Marcelino de Rezende Pinto

Ribeirão Preto - SP 
FERRARESI, P. D. Ensino fundamental de nove anos: uma ampliação de direitos? Dissertação apresentada à Faculdade de Filosofia, Ciências e Letras de Ribeirão Preto, Universidade de São Paulo - USP, para a obtenção do título de Mestre em Educação.

Aprovado em: 12 de dezembro de 2014

Banca Examinadora:

Prof $^{a}$ Dr $^{a}$ Lisete Regina Gomes Arelaro

Faculdade de Educação da Universidade de São Paulo

Prof $^{a}$ Dr $^{\mathrm{a}}$ Bianca Cristina Correa

Faculdade de Filosofia, Ciências e Letras de Ribeirão Preto

Prof $^{\circ}$ Dr $^{\circ}$ José Marcelino de Rezende Pinto

Faculdade de Filosofia, Ciências e Letras de Ribeirão Preto 
Dedico este trabalho a todos os autores das pesquisas que compuseram esta revisão de literatura, cujo esforço e dedicação à pesquisa em Educação possibilitaram esta iniciativa e tanto contribuíram para o debate sobre o ensino fundamental de nove anos. 


\section{Agradecimentos}

Ao Professor José Marcelino, pessoa admirável, sou muito grata por, em primeiro lugar, me aceitar como orientanda e topar se aventurar comigo no debate do ensino fundamental de nove anos. Sou grata em especial pelos ensinamentos, pela gentileza de sempre, pela abertura e acolhimento nas conversas, pela simplicidade que me serve de exemplo. Obrigada pela orientação neste trabalho e pelos caminhos trilhados juntos nestes dois anos.

À Professora Bianca, pela importante participação em minha formação, pelas conversas e debates sobre ensino fundamental de nove anos, pela leitura e contribuições dadas a este trabalho. Pelos ensinamentos nas disciplinas, e pelo exemplo de docente que conquistou minha admiração, sempre com uma postura de troca, ouvindo os alunos, e rindo com eles.

Às professoras Lisete Arelaro e Kátia Amorim, pela atenciosa e criteriosa leitura, pelas indagações e valiosas contribuições no exame de qualificação desta pesquisa. Para além da escrita, seus apontamentos indicaram caminhos e me ajudaram a crescer enquanto pesquisadora, com um amadurecimento do olhar e do fazer pesquisa em Educação.

Aos amigos da pós-graduação: Aline, Natália, Rafael e Neto, pelas manhãs e tardes de estudos na USP, pelos cafés, conversas, alegrias e frustrações partilhados nestes dois anos de minha vivência na USP. Em especial a Aline e Natália, pelas participações em congressos, viagens, risadas e companheirismo.

Aos demais integrantes do GEG - Grupo de Estudos em Gestão, pelas discussões e debates sempre interessantes e que contribuíram para minha formação ao me adentrar na área da Educação. Em especial à Aninha, cujas conversas me tranquilizaram frente a algumas angústias da vida acadêmica.

Aos amigos da Ong Cãopaixão, pela compreensão de minha ausência e apoio em meus estudos, e pela amizade duradoura, ainda que minha presença na ong tenha sido mais curta que minha posterior ausência. Finalizada esta conquista do mestrado, voltaremos a nos encontrar, com certeza.

À minha querida família, pelo incentivo e apoio de sempre, por junto comigo vivenciar os prazeres e desprazeres da pós-graduação, estando muito próximos ao mesmo tempo que a quilômetros de distância. Pelas boas palavras, pela confiança, pela 
disponibilidade em ajudar, e pelos bons momentos de distração tão revigorantes que me proporcionaram ao estarmos juntos. Aos meus pais, pelos ensinamentos e pelos exemplos de amor e dedicação. Às minhas irmãs, pelas travessuras, brincadeiras, descobertas, cuidados, sonhos, longas conversas, enfim, por todo companheirismo que me permitiram boas lembranças e muitos aprendizados. Em especial à minha querida mãe, que além de dar forças nas dificuldades, tornou cada momento mais agradável e feliz. E também em especial à Leila, que com todos os seus afazeres, prontamente me ajudou compartilhando comigo seus saberes e sanando minhas dúvidas.

Aos eternos amigos Alfredo e Sabrina, sou muito grata pelas palavras, pelo apoio, pelos ouvidos sempre dispostos a me ouvir. Pela compreensão, pela confiança, pelas risadas, e por não me deixarem esquecer do que é mais importante. Por me alegrarem apenas por estar presente, pelas boas lembranças, e pelas fantásticas e incríveis histórias que vivemos juntos. Por me entenderem melhor do que eu mesma, e por me mostrarem o valor da simplicidade da vida.

Aos "Bros", bons amigos, pela presença insubstituível e por todos os bons momentos de lazer e comilança que me renovavam a alma e a mente, apesar dos quilinhos a mais.

À Nina e à Maia, por todo carinho, divertimento e fidelidade. Por me alegrarem com sua simples presença, e por perdoarem minhas ausências com todo amor e nada de ressentimentos que só os cachorros podem ter. Que bom que nossos caminhos um dia se cruzaram!

Ao querido Lucas, amigo, companheiro e parceiro pra todas as horas, primeiramente pelo incentivo ao ingresso no mestrado, pelos debates do projeto, pelo apoio e expectativa, pela sincera alegria ao comemorar comigo minhas vitórias. Pelo apoio e incentivo às minhas descobertas, pelas palavras de incentivo e de acalento, pelos afagos nos momentos de frustração. Pelo chá e pelo olhar carinhoso num momento de desânimo. Por todo amor cotidiano que tornou o meu processo de mudança pessoal nesta jornada do mestrado mais gostoso, mais suave, e mais bem vindo.

Por fim, à Fundação do Amparo à Pesquisa do Estado de São Paulo - FAPESP, pelo apoio financeiro e oportunidade de dedicação exclusiva à pesquisa, e pelo auxílio na participação em congressos, possibilitando experiências de crescimento profissional e acadêmico, que não teriam sido possíveis sem este apoio. 
"Não há maior demonstração de insanidade do que fazer a mesma coisa, da mesma forma, dia após dia, e esperar resultados diferentes." 
FERRARESI, P. D. Ensino fundamental de nove anos: uma ampliação de direitos? 2015. Dissertação (Mestrado em Educação). Faculdade de Filosofia, Ciências e Letras de Ribeirão Preto, Universidade de São Paulo, Ribeirão Preto, 2015.

\section{RESUMO}

Após a promulgação da Lei $n^{\circ} 11.274 / 06$, que ampliou a duração do ensino fundamental para nove anos, diversos estudiosos voltaram seus olhares para esta temática, buscando investigar como se deu o processo de implantação dessa política. Com o grande número de produções sobre esse tema, cada qual com diferentes graus de abrangência, tornou-se possível e necessário analisar, de forma integrada, os resultados desses estudos para traçar um panorama geral de como se deu a implantação do ensino fundamental de nove anos em âmbito nacional. Assim, a presente pesquisa tem por objetivo analisar o que pesquisas empíricas indicam sobre a implantação do ensino fundamental de nove anos no país, e analisar as possíveis contribuições e os problemas gerados por essa política. A busca foi realizada nas bases de dados CAPES, SCIElo, Edubase, PePSIC, Anped e Biblioteca Digital Brasileira de Teses e Dissertações (BDTD), resultando em um total de 84 pesquisas. As pesquisas apontam para alguns problemas na implantação do ensino fundamental de nove anos, como a falta de participação dos professores nos processos de decisão, a ausência ou insuficiência dos cursos de formação continuada, a falta de adequação do espaço escolar para receber as crianças de seis anos, as alterações pouco significativas no currículo, as cobranças para a alfabetização das crianças de seis anos e a pouca valorização do brincar, que aparece restrito às sobras de tempo ou às aulas de Educação Física. Ainda, algumas pesquisas apontam para experiências positivas, em especial na construção de um novo currículo que contemple as necessidades das crianças de seis anos. O presente estudo permitiu observar que a maior parte das pesquisas concentrou seu foco de análise no primeiro ano do ensino fundamental, evidenciando a necessidade de investigações nos demais anos do ensino fundamental. Observou-se também a carência de pesquisas que busquem ouvir as crianças e suas contribuições sobre a implantação do ensino fundamental de nove anos. Por fim, acredita-se que o presente trabalho pode contribuir para o avanço das discussões sobre o ensino fundamental de nove anos.

Palavras-chave: ensino fundamental de nove anos; políticas públicas educacionais, ampliação do ensino fundamental. 


\begin{abstract}
After the promulgation of the Law $\mathrm{n}^{\circ} 11.274 / 06$, that expanded the Brazilian fundamental education to nine years, several researchers begin to study it, seeking to investigate how was the implementation process of this policy. With a large amount of productions about this topic, each with different degrees of coverage, it became possible and needed to analyze seamlessly these studies to draw a general outlook of how was the implementation of the nine-year fundamental education nationwide. This research aim to analyze what empirical researches indicates about the implementation of nine-year fundamental education in Brazil. The search for these researches was performed on CAPES, SCIElo, Edubase, PePSIC, Anped and Biblioteca Digital Brasileira de Teses (BDTD), resulting in a total of 84 studies. The researches pointed out to some problems in implementation of nine-year fundamental education, such as lack on the teacher's participation on the decision process, lack or insufficiency of the continuous formation course, lack of an adequate lieu on school to receive six years old children, low efficient alterations on curriculum, imposition to alphabetize six years old children and disregarding of the playfulness, that seems restrict to physical education classes or leftover time. Yet, several researches pointed out to some positives experiences, regarding the construction of a new curriculum, which covers the six years old children needs. This research pointed out that most of the studies focused the first year of the nine-year fundamental education, showing the need of investigations about the others years of the nine-year fundamental education. It also has been seen the lack of researches which aims to listen the children and they contribution on the implementation of the nine-year fundamental education. At last, we suggest that this research can contribute to the improvement of the discussions about the nine-year fundamental education.
\end{abstract}

Key-words: nine-year fundamental education; educational public politics, expansion of fundamental education. 


\section{LISTA DE SIGLAS}

ANPED - Associação Nacional de Pós-Graduação e Pesquisa em Educação

CEB - Câmara de Educação Básica

CEE - Conselho Estadual de Educação

CER - Centro de Educação e Recreação

CNE - Conselho Nacional de Educação

CEMEPE - Centro Municipal de Estudos e Projetos Educacionais de Uberlândia - Julieta Diniz

EAD - Educação à distância

EC - Emenda Constitucional

EF - Ensino Fundamental

EI - Educação Infantil

EMEF - Escola Municipal de Ensino Fundamental

LDB - Lei de Diretrizes e Bases da Educação Nacional

MEC - Ministério da Educação

NRE - Núcleo Regional de Educação

PNE - Plano Nacional da Educação

SAEB - Sistema Nacional de Avaliação da Educação Básica

SINEPE - Sindicato dos Estabelecimentos Particulares de Ensino do Estado do Paraná

SME - Secretaria Municipal de Educação

UNDIME - União Nacional dos Dirigentes Municipais de Educação

UNESCO - Organização das Nações Unidas para a Educação, a Ciência e a Cultura 


\section{LISTA DE QUADROS, TABELAS E FIGURAS}

Quadro 1: Roteiro para levantamento de dados das pesquisas analisadas

Quadro 2. Evolução normativa da obrigatoriedade escolar no Brasil republicano 24

Quadro 3: Matrícula das crianças de seis anos de idade em 1996 e 1998 41

Quadro 4: Organização do ensino fundamental e da educação infantil 52

Quadro 5. Texto original da LDB e as novas redações dadas pelas Leis 11.114/2005 e $11.274 / 2006$

Quadro 6: Conteúdo temático do curso de formação oferecido para professores de $1^{\circ}$ pela rede municipal de São Paulo (SP)

Quadro 7: Conteúdo temático do curso de formação oferecido para professores de $1^{\circ}$ ano pela rede municipal de Uberlândia (MG) 100

Quadro 8: Estrutura Curricular da $1^{\mathrm{a}}$ série do ensino fundamental de oito anos e do $1^{\mathrm{o}}$ ano do ensino fundamental de nove anos 120

Quadro 9: Rotina semanal do primeiro ano da Escola de Aplicação da Universidade de São Paulo

Tabela 1. Seleção dos estudos da revisão bibliográfica 20

Tabela 2. Acesso à escola por faixa etária para diferentes segmentos de renda no Brasil em 2008

Tabela 3. Número de matrículas no ensino fundamental de oito e nove anos

Tabela 4. Distribuição quantitativa dos estudos segundo a Unidade Federativa em que foi realizada a coleta de dados 79

Tabela 5. Caracterização das pesquisas quanto aos instrumentos de coleta de dados 81

Tabela 6. Caracterização das pesquisas quanto aos participantes 83

Tabela 7. Matriz curricular do $1^{\circ}$ ao $5^{\circ}$ ano do ensino fundamental 
Figura 1. Anos de estudo obrigatório em alguns países e nas regiões do mundo

Figura 2. Evolução do número de trabalhos publicados de 2006 a 2012 77

Figura 3. Distribuição dos estudos quanto à região de realização da coleta de dados 78

Figura 4. Inadequação do mobiliário para criança de seis anos: pés suspensos 103

Figura 5. Inadequação do mobiliário para crianças de seis anos: crianças não alcançam o pé no chão e buscam apoio no ferro lateral da cadeira 104

Figura 6. Professora levanta aluno para que ele alcance a lousa . 105

Figura 7. Ambiente lúdico em sala de aula confeccionado pela professora de $1^{\circ}$ ano 106

Figura 8. Outros brinquedos confeccionados pela professora de $1^{\circ}$ ano 107

Figura 9: Parque infantil de escola privada que atende Educação Infantil e $1^{\circ}$ ciclo do Fundamental. 112

Figura 10. Parque infantil de escola municipal que atende Educação Infantil e $1^{\circ}$ ciclo do Fundamental. 113

Figura 11. Pátio interno de escola municipal que atende a Educação Infantil e $1^{\circ}$ ciclo do Fundamental.

Figura 12. Organização em grupos em uma sala de aula de $1^{\circ}$ ano de escola municipal que atendia Educação Infantil e $1^{\circ}$ ciclo do Fundamental. 114

Figura 13. Sala de aula de primeiro ano. 115

Figura 14. Desenho de criança de seis anos sobre sua experiência escolar. 115

Figura 15. Atividade de caligrafia para crianças do $1^{\circ}$ ano do ensino fundamental. 125

Figura 16. Atividade de ditado realizada por crianças de primeiro ano. 128

Figura 17: Organização da lousa para atividade de cópia do cabeçalho. 129

Figura 18. Organização da lousa para atividade de cópia de texto. 130

Figura 19. Atividade de associação desenho-sílaba proposta para alunos de $1^{\circ}$ ano. 131

Figura 20: Crianças de seis anos indo para casa em fila. 133

Figura 21. Metas do ensino da escrita no $1^{\circ}, 2^{\circ}$ e $3^{\circ}$ anos do ensino fundamental. 136

Figura 22. Exemplos de avaliação mensal realizada pelas professoras com as crianças de primeiro ano. 
Figura 23. Crianças realizando avaliação externa.

Figura 24. Mural de resultados das avaliações externas com as crianças de seis anos.

Figura 25. Turma de primeiro ano em diferentes atividades desenvolvidas por meio de projetos, descritos por Silva (2011).

Figura 26. Brincadeiras dirigidas com as crianças de primeiro ano realizadas em aulas de Educação Física. 165

Figura 27. O que as crianças mais gostam de fazer na escola. 176

Figura 28. Desenho produzido por criança de seis anos em que ela se representa na sala de aula pensando no parque. 177

Figura 29. Desenho da escola produzido por criança de seis anos em que estão representados espaços como a quadra e o parque infantil. 178

Figura 30. Criança brincando durante a aula. 180

Figura 31. Criança brincando escondido embaixo da carteira. 181

Figura 32. Crianças, em sala de aula, brincam escondido embaixo da carteira. 181 


\section{SUMÁRIO}

APRESENTAÇÃO 14

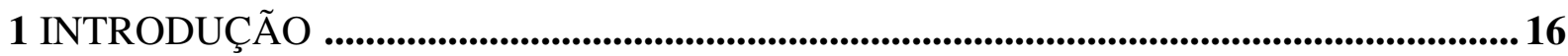

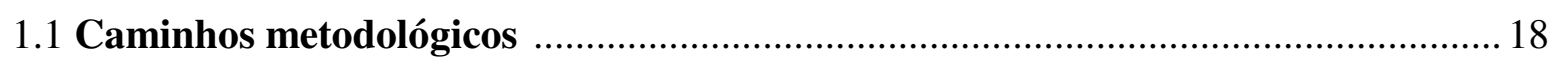

2 O ENSINO FUNDAMENTAL DE NOVE ANOS: MARCOS POLÍTICOS E LEGAIS.... 23

2.1 Considerações sobre a obrigatoriedade escolar: breve histórico normativo e cenário mundial

2.2 O Fundef e a matrícula de crianças de seis anos no ensino fundamental:

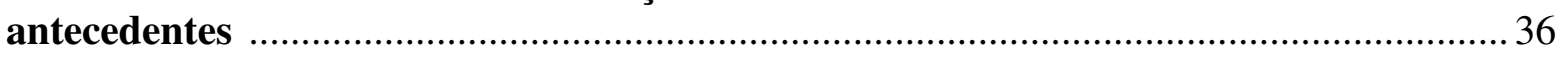

2.3 Legislação e documentos normativos do ensino fundamental de nove anos 46

2.4 Orientações do Ministério da Educação para a política do ensino fundamental de nove anos

2.4.1 Sobre os documentos publicados pelo Ministério da Educação 58

2.4.2 Sobre os objetivos da política do ensino fundamental de nove anos expressos nos documentos

2.4.3 Sobre as orientações do Ministério da Educação para implementação do ensino fundamental de nove anos

3 O QUE MOSTRAM AS PESQUISAS EMPÍRICAS SOBRE O ENSINO

FUNDAMENTAL DE NOVE ANOS

3.1 Perfil das pesquisas

3.2 Processo de implantação do ensino fundamental de nove anos

3.2.1 Participação dos professores no processo de implantação do ensino fundamental de nove anos 
3.2.2 Formação e preparação para os docentes do primeiro ano do ensino fundamental ..

3.2.3 Mudanças e readequações da escola para receber as crianças de seis anos 101

3.3 O referencial curricular do primeiro ano: conteúdos e práticas desenvolvidas com as crianças de seis anos

3.3.1 Estrutura curricular do primeiro ano do fundamental de nove anos: uma questão de novas nomenclaturas 118

3.3.2 Trabalho docente com as crianças de seis anos: falta de orientações e manutenção de práticas pedagógicas da antiga $1^{a}$ série

3.3.3 Contradições: orientações X cobranças

3.3.4 Breves considerações sobre a questão da avaliação no ensino fundamental de nove anos.

3.3.5 Breves considerações sobre os efeitos da ampliação do ensino fundamental sobre o currículo e práticas pedagógicas da Educação Infantil

3.3.6 Novo currículo, novas concepções e novas práticas: construções possíveis

3.4 O brincar no primeiro ano do ensino fundamental de nove anos: "brincar, só depois de estudar e para quem se comportar"

ANEXOS

ANEXO 1

ANEXo 2

Anexo 3

ANEXo 4

ANEXo 5 


\section{APRESENTAÇÃ̃o}

Compreendendo que o fazer pesquisa se relaciona com o olhar do pesquisador e sua trajetória acadêmica, esta apresentação visa situar-me enquanto pesquisadora e autora desta dissertação.

Com minhas lembranças e vivências de anos e anos na escola, passei a me interessar pelo debate da educação. Quando adolescente, eu dizia que um dia iria abrir minha própria escola, que fugisse dos moldes tradicionais de ensino. Questionava as idas e vindas dos professores, as rápidas trocas de aula, o conteúdo sem sentido, a repressão da criatividade, os horários rígidos, assim como muitas outras normas. Sem nenhuma instrução a respeito da educação, comecei a me interessar por seu debate a partir de minhas próprias vivências.

Durante minha formação de psicologia, as vivências eram diferentes e requisitavam postura crítica, até então reprimida na escola fundamental e ensino médio. A partir de então um novo mundo se abriu, e a passei a trilhar por diferentes áreas da psicologia. Foi por meio de experimentos em laboratório e análises estatísticas que aprendi muito sobre o fazer pesquisa, através de minha iniciação científica em Psicobiologia. Aprendi sobre os cuidados éticos, sobre a responsabilidade do pesquisador, sobre a escrita acadêmica, sobre as diferentes possibilidades de análise, enfim, sobre o fazer ciência.

Nos últimos dois anos de graduação, foi por meio das disciplinas de licenciatura que, pela primeira vez, estudei sobre a educação, sobre a relação professor-aluno, sobre a docência, sobre teorias e pensadores dessa área. A partir dessas experiências, encantei-me pela área, e aquela vontade de adolescente de contribuir para a superação dos problemas na educação havia sido resgatada.

Após a formação universitária, ingressei na pós-graduação buscando me aprofundar na intersecção entre as áreas da Psicologia e da Educação, cursando especialização em Psicologia Aplicada à Educação. Foi neste contexto que tomei conhecimento da proposta do ensino fundamental de nove anos, que, em 2010, já fazia parte das escolas. Porém, poucos dos profissionais da educação sabiam me informar sobre os objetivos da política e sua origem. Com o intuito de compreender mais a fundo esta política e contribuir para seu debate, decidir fazer o trabalho de conclusão do curso sobre este tema. Assim, nasceu a primeira pesquisa que realizei sobre o ensino fundamental de nove anos, cujo objetivo era analisar sua implantação no município de Londrina, Paraná, por meio de entrevistas com professores de primeiro ano. 
Este trabalho me possibilitou compreender os objetivos da proposta e algumas dificuldades vivenciadas pelas escolas e pelos professores em sua implantação. No entanto, concluído o trabalho, surgiu-me a inquietação sobre o quanto os resultados obtidos refletiam a realidade vivenciada por outras escolas em outros municípios.

Com isso, observando a carência de produções sobre a temática que traçassem um panorama mais geral sobre a implantação do ensino fundamental de nove anos, surgiu-me a ideia da revisão de literatura sobre o tema. Assim, busquei pela pós-graduação stricto sensu e ingressei, em 2012, no mestrado em Educação, agora na área de políticas públicas. Sem muita bagagem nesta área, a experiência do mestrado representou para mim um desafio, com intenso e constante aprendizado sobre educação. Após os aprendizados e experiências vivenciados no mestrado, o meu olhar e entendimento sobre o ensino fundamental de nove anos mudaram e aprofundaram-se, conseguindo compreender esta medida como parte de todo um contexto e história vividos no Brasil e no mundo. Nesse trajeto, a ideia inicial da revisão de literatura foi se aperfeiçoando, até tomar as formas descritas na presente pesquisa. 


\section{INTRODUÇÃO}

O ano de 2006 representa importante marco na educação brasileira ao ampliar a duração do ensino fundamental para nove anos, com ingresso aos seis anos de idade, por meio da Lei Federal $n^{\circ}$ 11.274, aprovada em fevereiro daquele ano. Apesar da ampliação desta etapa de ensino já estar prevista desde 2001, como meta apresentada no Plano Nacional de Educação, sua implantação surpreendeu a comunidade educacional e acadêmica. Tendo como prazo para implantação o ano de 2010, os sistemas de ensino e as escolas tiveram que se reorganizar e se adaptar para a inclusão das crianças de seis anos no ensino fundamental.

Visando nortear os sistemas de ensino e escolas neste processo de implantação do ensino fundamental de nove anos, o Ministério da Educação produziu documentos com informações sobre a política e orientações para o processo de implantação. Dentre as orientações, o Ministério da Educação ressaltava a necessidade de adequar o espaço escolar para as crianças de seis anos, de ofertar formação continuada para os docentes, de reorganizar o currículo do ensino fundamental, bem como de atender as necessidades das crianças de seis anos, em especial quanto à brincadeira e ludicidade.

Em face desse cenário, a pesquisa sobre o ensino fundamental de nove anos ganhou relevância para o debate desta política e de sua implantação nos estados e municípios. Foram impulsionados diversos estudos sobre a temática, que se utilizavam de variados olhares e focos de estudo: os documentos do Ministério da Educação, o processo de implantação nos municípios, a visão dos professores, de gestores, de pais e de alunos, entre outros. Porém, como não poderia ser diferente, grande parte dessas pesquisas esteve restrita aos limites do contexto educacional estudado. Já agora, com o volume considerável de pesquisas sobre o ensino fundamental de nove anos, torna-se possível e necessário traçar um panorama mais abrangente sobre a implantação desta política, considerando esse universo de estudos já realizados.

Portanto, o presente trabalho teve como objetivo analisar os resultados encontrados pelas diferentes pesquisas sobre a implantação do ensino fundamental de nove anos, bem como discutir as possíveis contribuições e problemas gerados com esta política a partir dos resultados dessas pesquisas.

A partir da leitura prévia dos estudos sobre o ensino fundamental de nove anos, definiu-se como objetivos específicos: 
- Analisar os dados das pesquisas sobre as mudanças e readequações da escola necessárias previstas nos documentos elaborados pelo Ministério da Educação sobre o ensino fundamental de nove anos.

- Avaliar o que os estudos mostram sobre a participação de professores nos processos de decisão, aprovação e implantação da política do ensino fundamental de nove anos.

- Avaliar o que as pesquisas mostram sobre a oferta de formação docente para a nova organização do ensino fundamental e o que dizem os professores e outros profissionais da educação a respeito dos cursos.

- Verificar e analisar os dados das pesquisas sobre os conteúdos e diretrizes que estão sendo adotados e praticados no $1^{\circ}$ ano do ensino fundamental e se estes atendem as orientações do Ministério da Educação.

- Investigar, no rol dos estudos selecionados, quais as formas avaliativas empregadas no $1^{\mathrm{o}}$ ano do ensino fundamental e discutir suas implicações.

- Analisar o que mostram as pesquisas sobre a presença do lúdico no contexto do ensino fundamental de nove anos e seu uso no cotidiano escolar, e verificar se atendem às orientações do Ministério da Educação.

- Investigar o que relatam as pesquisas sobre o processo de transição da Educação Infantil para Ensino Fundamental com a nova organização da educação básica.

- Verificar quais as dificuldades mais relatadas pelas pesquisas e quais os avanços e melhoras conquistados com o ensino fundamental de nove anos apontados pelas pesquisas empíricas.

Diante da necessidade de traçar um panorama mais abrangente sobre o ensino fundamental de nove anos, alguns pesquisadores também tiveram a iniciativa de analisar as pesquisas sobre o ensino fundamental de nove anos. Durante a realização da pesquisa, foi possível identificar cinco estudos que tiveram esta iniciativa: Colombi e Carvalho (2012), Nogueira e Peres (2011), Sarmento, Silva e Pauly (2011), Souza e Scaff (2011) e Rocha, Martinati e Santos (2011). Dentre eles, quatro são artigos publicados em periódicos e um se trata de um trabalho apresentado na Anped.

A presente pesquisa se insere neste movimento, mas diferencia-se das demais revisões de literatura sobre o ensino fundamental de nove anos quanto à abrangência dos estudos analisados, quanto à natureza sistemática da análise e quanto à preocupação em contextualizar os resultados encontrados por esses estudos. Com isso, acredita-se que a presente pesquisa poderá contribuir para o debate sobre a política do ensino fundamental de nove anos e, quiçá, 
na proposição de novas medidas referentes à sua implantação e na elaboração futura de novas propostas para a educação brasileira. A seguir, serão tratados mais detalhadamente os caminhos e procedimentos metodológicos adotados nesta revisão.

\subsection{Caminhos metodológicos}

Para alcançar os objetivos da pesquisa, adotou-se como metodologia a revisão sistemática, que, assim como outros tipos de estudo de revisão, é uma forma de pesquisa que utiliza como fonte de dados a literatura sobre determinado tema. A revisão sistemática, no entanto, difere da revisão tradicional por buscar superar possíveis vieses, seguindo um método rigoroso de busca e seleção de pesquisas, avaliação da relevância e validade das pesquisas encontradas, bem como da coleta, síntese e interpretação dos dados oriundos das pesquisas (GALVÃO, SAWADA e TREVIZAN, 2004).

Segundo Sampaio e Mancini (2006), esta metodologia é útil para integrar as informações de um conjunto de estudos realizados separadamente sobre uma mesma intervenção, que podem apresentar resultados conflitantes e/ou coincidentes. A revisão sistemática também é útil para identificar temas que necessitam de evidência, auxiliando na orientação para investigações futuras, e possibilitando a generalização dos resultados entre populações (SAMPAIO e MANCINI, 2006). Assim, a revisão sistemática foi a metodologia de pesquisa entendida com a mais adequada para alcançar o objetivo a que se propôs esta pesquisa, por possibilitar a integração dos estudos sobre o ensino fundamental de nove anos e a análise de seus resultados, considerando que já há um número significativo de estudos sobre o tema.

Desta forma, a presente pesquisa configura-se como uma revisão sistemática do tema "ensino fundamental de nove anos", tendo como questão norteadora: "o que mostram as pesquisas sobre a implementação da política do ensino fundamental de nove anos?". Neste sentido, estabeleceu-se como critério de seleção aqueles estudos que relatassem pesquisas empíricas. Vale ressaltar que os estudos que ofereciam importantes dados para a pesquisa e que não se tratavam de uma pesquisa empírica não foram selecionados como resultados da busca, mas foram utilizados na discussão e fundamentação teórica para que os conhecimentos, avanços e discussões importantes presentes nesses trabalhos fossem também aproveitados. 
A estratégia de busca consistiu na pesquisa em bancos de dados eletrônicos, por ser esta uma forma mais viável de acesso a estudos realizados em todo o território nacional. $\mathrm{O}$ tipo de fonte consultada consistiu de trabalhos em congresso (especificamente, as reuniões anuais da Associação Nacional de Pós-graduação e Pesquisa em Educação - Anped), artigos, dissertações e teses.

Os bancos de dados eletrônicos selecionados para a pesquisa foram: CAPES (periódicos e teses e dissertações), SCIElo, Edubase, PePSIC, Anped, e Biblioteca Digital Brasileira de Teses e Dissertações (BDTD), escolhidos em virtude de sua universalidade e variedade de periódicos indexados, possibilitando o acesso a um maior número de estudos provenientes de diversas regiões do Brasil.

Para a busca na CAPES, SCIElo, Edubase, PePSIC e BDTD foi utilizado o descritor "ensino fundamental de nove anos", assim como suas variações: "ensino fundamental de 9 anos" e "ensino fundamental ampliado", definidos tomando-se por base as palavras-chave utilizadas nos artigos encontrados em uma prévia análise do campo de pesquisa. Já a busca na Anped envolveu uma análise dos trabalhos apresentados nas reuniões anuais de 2006 a 2012, nos seguintes GTs: GT05 - Estado e Política educacional; GT07 - Educação de crianças e 0 a 6 anos; GT08 - Formação de professores; GT10 - Alfabetização, leitura e escrita; e GT13 Educação fundamental. Foram selecionados aqueles trabalhos que abordavam o tema do ensino fundamental de nove anos e que atendiam aos critérios de seleção.

Foram resgatados na busca um total de 290 trabalhos, entre artigos, teses, dissertações e trabalhos apresentados na Anped. No processo de seleção dos estudos, em um primeiro momento foram excluídos os trabalhos que se repetiram numa mesma base de dados e/ou entre as bases de dados (apareceram mais de uma vez no levantamento). Em um segundo momento, a partir da leitura do título e resumo dos trabalhos, foram excluídos aqueles que se distanciavam do tema desta pesquisa. Posteriormente, durante a leitura na íntegra dos trabalhos, foram excluídos outros trabalhos que também se distanciavam do tema da pesquisa.

Vale notar que tanto os artigos como os trabalhos apresentados na Anped muitas vezes resultam de pesquisas desenvolvidas na pós-graduação, resumindo seus principais dados ou apresentando um recorte da pesquisa. Em alguns casos, uma mesma dissertação ou tese pode fundamentar mais de um artigo. Dessa maneira, a partir de uma leitura na íntegra dos trabalhos, foram excluídos os artigos e trabalhos da Anped que se tratavam de uma mesma pesquisa encontrada na forma de tese ou dissertação, para evitar a repetição de dados e 
contribuições das pesquisas, e por se entender que a tese/dissertação é mais completa e detalhada na descrição e discussão dos resultados encontrados nas pesquisas.

Ainda na fase de leitura e seleção dos estudos, houve quatro dissertações que surgiram na busca realizada no Banco de Teses da Capes, mas que não foram encontradas na íntegra, constando apenas os resumos destes trabalhos. São elas os trabalhos de Márcia Patrícia Barbosa de Souza (2009) ${ }^{1}$, Milena Monteiro da Silva (2012) ${ }^{2}$, Regina Celia dos Santos Camara $(2012)^{3}$, e Sueli Machado Pereira de Oliveira (2011) ${ }^{4}$. Para melhor atender aos objetivos desta pesquisa, optou-se pela exclusão de tais estudos e seleção apenas de estudos na íntegra.

Assim, ao final deste processo de seleção dos estudos, contamos com um total de 84 estudos analisados. A Tabela 1 mostra quantitativamente o processo de seleção dos estudos segundo cada critério de exclusão.

Tabela 1. Seleção dos estudos da revisão bibliográfica.

\begin{tabular}{|c|c|c|c|c|c|c|c|}
\hline \multirow[t]{2}{*}{ Bases de dados } & \multirow{2}{*}{$\begin{array}{c}\text { Estudos } \\
\text { encontrados } \\
\text { na busca }\end{array}$} & \multicolumn{5}{|c|}{ Critérios de exclusão } & \multirow{2}{*}{$\begin{array}{c}\text { Artigos } \\
\text { selecionados }\end{array}$} \\
\hline & & $\begin{array}{c}\text { Estudos } \\
\text { repetidos } \\
\text { na busca } \\
\end{array}$ & $\begin{array}{c}\text { Estudos } \\
\text { repetidos } \\
\text { entre bases } \\
\end{array}$ & $\begin{array}{c}\text { Estudos que } \\
\text { fogem ao tema } \\
\text { de pesquisa }\end{array}$ & $\begin{array}{l}\text { Estudos não } \\
\text { empíricos }\end{array}$ & $\begin{array}{c}\text { Estudos não } \\
\text { encontrados } \\
\text { na íntegra } \\
\end{array}$ & \\
\hline BDTD & 54 & 2 & 0 & 14 & 5 & 0 & 33 \\
\hline $\begin{array}{l}\text { Banco de Teses } \\
\text { da Capes }\end{array}$ & 96 & 0 & 45 & 14 & 4 & 4 & 29 \\
\hline $\begin{array}{l}\text { Periódicos } \\
\text { Capes }\end{array}$ & 29 & 4 & 2 & 4 & 8 & 0 & 11 \\
\hline Scielo & 19 & 2 & 15 & 0 & 2 & 0 & 0 \\
\hline Edubase & 59 & 6 & 17 & 27 & 5 & 0 & 4 \\
\hline Pepsic & 20 & 0 & 1 & 16 & 1 & 0 & 2 \\
\hline Anped & 13 & - & 4 & - & 4 & 0 & 5 \\
\hline TOTAL & 290 & 14 & 84 & 75 & 29 & 4 & 84 \\
\hline
\end{tabular}

Fonte: A autora.

\footnotetext{
${ }^{1}$ Dissertação intitulada "Formação continuada de professoras dos anos iniciais do Ensino Fundamental de 9 anos: estudo da política de formação implementada pela secretaria da Educação de Juiz de Fora (2006-2008)".

${ }^{2}$ Dissertação intitulada "Ensino fundamental de nove anos: discurso sobre o ciclo da infância".

${ }^{3}$ Dissertação intitulada "A alfabetização e o ensino fundamental de nove anos: os desafios do $1^{\circ}$ ano".

${ }^{4}$ Dissertação intitulada "A implantação do ensino fundamental de nove anos em minas gerais: a visão da criança".
} 
Nota-se que a busca por artigos no SCIElo acabou por resultar em nenhum trabalho selecionado. Como se pode observar na Tabela 1, grande parte dos trabalhos encontrados nesse portal já haviam sido incorporados na revisão ao se fazer a busca na Capes $(n=15)$. Restavam ainda dois trabalhos que, no entanto, não descreviam pesquisa empírica e, portanto, não foram selecionados para análise. Ainda assim, optamos por manter na Tabela 1 os resultados da seleção na Scielo visando divulgar os números de trabalhos encontrados neste nosso esforço de abarcar todas essas bases de dados. Os títulos dos trabalhos, nomes dos autores e ano de publicação de cada trabalho analisado podem ser visualizados no Anexo 4.

Durante a leitura e análise dos trabalhos selecionados, foram realizados levantamentos de cada estudo quanto aos objetivos da pesquisa, sua abrangência, procedimentos adotados e os resultados encontrados, incluindo dados específicos como a cidade de realização da pesquisa empírica, técnica de coleta de dados empregada e número de participantes. Para padronizar este levantamento, foi elaborado um roteiro com estas informações, preenchido durante a leitura dos trabalhos (Quadro 1).

Quadro 1: Roteiro para levantamento de dados das pesquisas analisadas.

\begin{tabular}{|l|c|c|c|c|}
\hline Autor; ano & $\begin{array}{c}\text { Local da coleta de } \\
\text { dados }\end{array}$ & $\begin{array}{c}\text { Instrumentos de } \\
\text { coleta de dados }\end{array}$ & $\begin{array}{c}\text { Participantes das } \\
\text { entrevistas e/ou } \\
\text { questionários }\end{array}$ & $\begin{array}{c}\text { Abrangência do } \\
\text { estudo }\end{array}$ \\
\hline & & & & \\
\hline
\end{tabular}

Fonte: A autora.

A partir deste roteiro tornou-se mais fácil a visualização das informações de cada estudo, auxiliando na análise. Além disso, o levantamento desses dados permitiu compreender o perfil das pesquisas e da produção sobre o ensino fundamental de nove anos. Os roteiros preenchidos com as informações dos 84 estudos analisados podem ser vistos no Anexo 5.

Através da leitura exaustiva dos artigos, teses e dissertações, buscou-se compreender quais foram os tópicos mais frequentemente investigados e discutidos pelas pesquisas. A partir disso, foram definidos os seguintes temas, considerando os objetivos da pesquisa: (a) participação docente no processo de implantação do ensino fundamental de nove anos; (b) formação docente para o trabalho com as crianças de seis anos; (c) readequação da escola para receber as crianças de seis anos; (d) referencial curricular do primeiro ano; (e) alguns efeitos 
da ampliação do ensino fundamental sobre o currículo e práticas pedagógicas da Educação Infantil; (f) formas avaliativas no primeiro ano; e (g) o brincar no cotidiano escolar do primeiro ano do ensino fundamental.

Vale ressaltar que o foco no primeiro ano foi assim definido seguindo a predominância observada nos trabalhos analisados, sendo poucos os trabalhos que abordaram os demais anos do Ensino Fundamental e a Educação Infantil. Cabe comentar, ainda, que também foi realizada pesquisa documental tendo como foco os documentos, leis e pareceres emitidos pelo Ministério da Educação referentes ao ensino fundamental de nove anos, buscando com isso aprofundar a discussão dessa política.

Conforme afirma Santos (2010), ao se discutir uma política, é preciso, em primeiro lugar, considerar os contextos em que ela foi produzida: o local e o internacional. Assim, o presente trabalho encontra-se estruturado da seguinte forma: no primeiro capítulo, são abordados os marcos políticos e legais que influenciaram a política do ensino fundamental de nove anos, buscando apresentar o contexto nacional e também internacional que produziram essa política. Além disso, discute-se algumas considerações acerca dessa política e as orientações do Ministério da Educação sobre medidas necessárias na implementação do ensino fundamental de nove anos.

No segundo capítulo, serão apresentados e discutidos os resultados encontrados na análise das pesquisas sobre o ensino fundamental de nove anos. Em um primeiro momento, apresenta-se o perfil das pesquisas analisadas, traçado por meio de levantamento de informações como local, instrumentos de coleta de dados, participantes da pesquisa, e abrangência do estudo. Em um segundo momento, são articulados os principais resultados das pesquisas sobre o ensino fundamental de nove anos. Neste esforço, foram trazidos à discussão alguns dos dados coletados pelas pesquisas, como a fala de participantes, fotos de observações nas escolas, desenhos produzidos pelos alunos, quadros, tabelas e esquemas.

Por fim, nas Considerações Finais são apresentadas algumas reflexões diante da análise do que mostram as pesquisas sobre a implantação do ensino fundamental de nove anos. 


\section{O ENSINo Fundamental de Nove AnOS:}

\section{Marcos Políticos e Legais}

Para se discutir a política do ensino fundamental de nove anos, é necessário levar em consideração o contexto em que foi proposta esta medida, assim como suas intenções e as ações dos órgãos públicos para sua implementação. Assim, no presente capítulo serão tratados de temas como obrigatoriedade escolar e o financiamento da educação, bem como da legislação, normas, e orientações do Ministério da Educação sobre o ensino fundamental de nove anos.

\subsection{Considerações sobre a obrigatoriedade escolar: breve histórico normativo e cenário mundial.}

A política do ensino fundamental de nove anos, ao ampliar esta etapa de ensino, ampliou a duração do ensino obrigatório para nove anos, determinando a faixa etária dos 6 aos 14 anos para a obrigatoriedade escolar. Essas mudanças nos remetem às transformações históricas acerca da educação obrigatória, ocorridas tanto no Brasil quanto em outros países. Com o intuito de contextualizar a política do ensino fundamental de nove anos no movimento de ampliação do ensino obrigatório, serão apontados no presente tópico os principais marcos normativos quanto à expansão do ensino obrigatório no Brasil, situando-o com relação a outros países. Vale ressaltar a importância das lutas e dos movimentos sociais pelo direito à educação e sua influência nas determinações legais que dispõem sobre a obrigatoriedade do ensino, sendo relevantes as discussões que os analisem em sua complexidade, tais como aquelas realizadas por Gohn (2009) e Rosar (2011). Esta discussão, porém, não será abordada neste tópico, que busca se ater ao foco descrito acima.

O ensino obrigatório, previsto por lei para um período determinado da infância e juventude, tem sido uma das estratégias adotadas por diversos países para viabilizar o exercício do direito à educação a todos os segmentos da sociedade (PINTO e ALVES, 2010). O Brasil tem se utilizado da definição da obrigatoriedade para uma etapa de ensino ou faixa etária desde 1934. O Quadro 2 apresenta os instrumentos normativos que trataram da 
obrigatoriedade escolar na história do Brasil até o momento atual, que serão discutidos neste tópico.

Quadro 2. Evolução normativa da obrigatoriedade escolar no Brasil republicano.

\begin{tabular}{|c|c|}
\hline $\begin{array}{l}\text { Instrumento } \\
\text { normativo }\end{array}$ & Natureza e abrangência da obrigatoriedade \\
\hline CF de 1891 & Inexiste a obrigatoriedade ou o direito. \\
\hline CF de 1934 & $\begin{array}{l}\text { Ensino primário integral gratuito e de frequência obrigatória, } \\
\text { extensivo aos adultos. }\end{array}$ \\
\hline CF de 1937 & $\begin{array}{l}\text { Ensino primário obrigatório e gratuito (cabendo, porém, "para os } \\
\text { que não alegarem ou notoriamente não puderem alegar escassez de } \\
\text { recursos, uma contribuição módica e mensal para a caixa escolar."). }\end{array}$ \\
\hline CF de 1946 & Ensino primário obrigatório. \\
\hline CF de 1967 & Ensino obrigatório dos 7 aos 14 anos (não define etapa). \\
\hline Lei $\mathrm{n}^{0} 5.692 / 1971$ & Ensino de $1^{\circ}$ grau obrigatório de oito anos de duração. \\
\hline CF de 1988 & $\begin{array}{l}\text { Ensino fundamental obrigatório ( } 8 \text { anos de duração) } \\
\text { independentemente da idade. }\end{array}$ \\
\hline $\mathrm{EC} \mathrm{n}^{\circ} 14 / 96$ & $\begin{array}{l}\text { Ensino fundamental obrigatório ( } 8 \text { anos de duração) apenas para a } \\
\text { faixa etária ideal ( } 7 \text { a } 14 \text { anos). }\end{array}$ \\
\hline Lei $\mathrm{n}^{\circ} 11.274 / 2006$ & $\begin{array}{l}\text { Ensino fundamental com } 9 \text { anos de duração (a obrigatoriedade } \\
\text { amplia-se para a faixa de } 6 \text { a } 14 \text { anos). }\end{array}$ \\
\hline EC n 59/ 2009 & Ensino obrigatório de 4 a 17 anos (não estabelece a etapa obrigatória). \\
\hline
\end{tabular}

Fonte: Pinto e Alves (2010), p. 214.

É na Constituição Federal de 1934 que se viu pela primeira vez, na letra da lei, a educação como direito de todos: "a educação é direito de todos e deve ser ministrada pela família e pelos Poderes Públicos” (Art. 149). Esta mesma Constituição instituiu, também pela primeira vez, o ensino primário gratuito e de frequência obrigatória, com duração de quatro anos (PINTO e ALVES, 2010), conforme afirmado em seu Art. 150:

a) ensino primário integral gratuito e de frequência obrigatória extensivo aos adultos;

b) tendência à gratuidade do ensino educativo ulterior ao primário, a fim de o tornar mais acessível (BRASIL, 1934).

O ensino primário obrigatório foi mantido pela Constituição seguinte, datada de 1937. No entanto, esta Constituição estabelecia a gratuidade do ensino somente para aqueles que comprovassem a insuficiência de recursos: “por ocasião da matrícula, será exigida aos que 
não alegarem, ou notoriamente não puderem alegar escassez de recursos, uma contribuição módica e mensal para a caixa escolar" (BRASIL, 1937, Art. 130).

A gratuidade do ensino primário e a educação como direito de todos os cidadãos foram reafirmadas na Constituição Federal de 1946, como se observa em seus Art. 166, 167 e 168:

Art 166 - A educação é direito de todos e será dada no lar e na escola. Deve inspirar-se nos princípios de liberdade e nos ideais de solidariedade humana.

Art 167 - O ensino dos diferentes ramos será ministrado pelos Poderes Públicos e é livre à iniciativa particular, respeitadas as leis que o regulem.

Art 168 - A legislação do ensino adotará os seguintes princípios:

I - o ensino primário é obrigatório e só será dado na língua nacional;

II - o ensino primário oficial é gratuito para todos; o ensino oficial ulterior ao primário sê-lo-á para quantos provarem falta ou insuficiência de recursos; [...] (BRASIL, 1946).

A Constituição de 1946 afirmava, ainda, que a etapa seguinte ao ensino primário seria ofertada de forma gratuita para aqueles que provassem falta ou insuficiência de recursos, como se observa no Art. 168 citado acima.

A Lei n $n^{\circ} 4024$ de 20 de dezembro de 1961 estabelecia quatro anos de ensino primário (BRASIL, 2004a). Foi com a Constituição Federal de 1967 que o ensino obrigatório e gratuito foi ampliado, determinando duração de oito anos. Se até o momento a obrigatoriedade do ensino era definida pela etapa de ensino, a Constituição de 67 mudou esta lógica, determinando o ensino gratuito e obrigatório para a faixa etária de 7 a 14 anos (PINTO e ALVES, 2010; PINTO e ALVES, 2011). Ainda, a Constituição de 67, em seu Art. 176, reconheceu pela primeira vez no texto de uma Constituição brasileira a educação como "direito de todos e dever do Estado" (BRASIL, 1967). Cabe comentar que a mesma Constituição, em plena ditadura militar, ao retirar a vinculação de impostos para o ensino, inviabilizou qualquer forma efetiva do Estado garantir este direito.

Em 1962, com o Acordo de Punta Del Este e Santiago, o governo brasileiro assumiu a obrigação de estabelecer a duração de seis anos de ensino primário, prevendo cumpri-la até 1970 (BRASIL, 2004a). Em 1971, a lei no 5.692 (Lei de Diretrizes e Bases da Educação Nacional de 1971) fundiu os antigos Ensino Primário e Ginasial, formando o ensino de primeiro grau com duração de oito anos (JACOMINI, ROSA e ALENCAR, 2012). A idade estabelecida para ingresso nesse nível de ensino manteve-se a estabelecida pela Constituição de 67: 7 anos (MORO, 2009). Entretanto, o Art. 19, que dispunha sobre a idade de ingresso, já abria a possibilidade para a matrícula de crianças com menos de 7 anos no primeiro grau 
(MORO, 2009), ao afirmar em seu inciso $1^{\circ}$ : “As normas de cada sistema disporão sobre a possibilidade de ingresso no ensino de $1^{\circ}$ grau de alunos com menos de 7 (sete) anos de idade" (BRASIL, 1971).

A Constituição Federal de 1988, vigente até o momento atual, mudou a denominação de ensino de primeiro grau para Ensino Fundamental, não havendo alterações quanto à sua duração, obrigatoriedade e gratuidade (JACOMINI, ROSA e ALENCAR, 2012). Em seu texto original, não havia menção à faixa etária como na Constituição de 67. O Art. 205 do capítulo da Educação reafirma a educação como direito de todos e dever do Estado, definindo como metas para a educação o "pleno desenvolvimento da pessoa, seu preparo para o exercício da cidadania e sua qualificação para o trabalho" (BRASIL, 1988). O Art. 208, em sua versão original de 1988, definia que:

Art. 208. O dever do Estado com a educação será efetivado mediante a garantia de:

I - ensino fundamental, obrigatório e gratuito, inclusive para os que a ele não tiveram acesso na idade própria;

II - progressiva extensão da obrigatoriedade e gratuidade ao ensino médio;

III - atendimento educacional especializado aos portadores de deficiência, preferencialmente na rede regular de ensino;

IV - atendimento em creche e pré-escola às crianças de zero a seis anos de idade;

V - acesso aos níveis mais elevados do ensino, da pesquisa e da criação artística, segundo a capacidade de cada um;

VI - oferta de ensino noturno regular, adequado às condições do educando;

VII - atendimento ao educando, no ensino fundamental, através de programas suplementares de material didático-escolar, transporte, alimentação e assistência à saúde.

$\S 1^{\circ}$ - O acesso ao ensino obrigatório e gratuito é direito público subjetivo.

$\S 2^{\circ}$ - O não-oferecimento do ensino obrigatório pelo Poder Público, ou sua oferta irregular, importa responsabilidade da autoridade competente.

$\S 3^{\circ}$ - Compete ao Poder Público recensear os educandos no ensino fundamental, fazer-lhes a chamada e zelar, junto aos pais ou responsáveis, pela frequência à escola (BRASIL, 1988).

Dessa forma, a Constituição Federal de 88 declarou como princípios do ensino a igualdade de condições de acesso e permanência à escola, colocando como dever do Estado a garantia do ensino obrigatório e gratuito a todos os cidadãos. Como afirma Rosemberg (2009), ao adotar esta concepção nos $\S 1^{\circ}$ e $\S 3^{\circ}$ do Art. 208, a Constituição de 1988 criou instrumentos para forçar o Estado a cumprir com a prescrição de sua parte na obrigatoriedade escolar. O Art. 208 mostra, ainda, que pela primeira vez em lei, a etapa da Educação Infantil é 
afirmada como um direito (CORREA, 2007; CORREA, 2011b; GUIMARÃES e PINTO, 2001), sendo dever do Estado garantir o atendimento às crianças em creches e pré-escolas.

O Estatuto da Criança e do Adolescente, Lei no 8069, aprovado em 1990, contribuiu para a consolidação normativa das conquistas quanto ao direito à educação alcançadas com a Constituição de 88 (CORREA, 2007; CORREA, 2011b; GUIMARÃES e PINTO, 2001). Entre outras disposições que afirmam este direito, a Lei no 8069/90 afirma:

A criança e o adolescente têm direito à educação, visando ao pleno desenvolvimento de sua pessoa, preparo para o exercício da cidadania e qualificação para o trabalho, assegurando-se-lhes:

I - igualdade de condições para o acesso e permanência na escola;

II - direito de ser respeitado por seus educadores;

III - direito de contestar critérios avaliativos, podendo recorrer às instâncias escolares superiores;

IV - direito de organização e participação em entidades estudantis;

$\mathrm{V}$ - acesso à escola pública e gratuita próxima de sua residência.

Parágrafo único. É direito dos pais ou responsáveis ter ciência do processo pedagógico, bem como participar da definição das propostas educacionais (BRASIL, 1990).

Também em seu Art. 54 a Lei no $8069 / 90$ reafirma o posto pela Constituição de 88 quanto ao dever do Estado em assegurar o acesso ao ensino gratuito e obrigatório (BRASIL, 1990).

Em setembro de 1996 é aprovada a Emenda Constitucional nº 14, que além de outras disposições, altera o inciso I do Art. 208 da Constituição de 1988, que passa a vigorar com o seguinte texto: "ensino fundamental, obrigatório e gratuito, assegurada, inclusive, sua oferta gratuita para todos os que a ele não tiveram acesso na idade própria" (BRASIL, 1996a). Esta alteração do texto menciona apenas a gratuidade da educação para aqueles que não tiveram acesso na idade própria (7 a 14 anos), sem mencionar sua obrigatoriedade (PINTO e ALVES, 2010; 2011). Assim, apesar de não fazer menção direta à idade de 7 a 14 anos, a Emenda $n^{\circ}$ 14/96 retomava a obrigatoriedade do ensino para uma determinada faixa etária, mencionada como a “idade própria” (PINTO e ALVES, 2010; 2011).

Apesar de não dispor sobre a obrigatoriedade escolar, vale ressaltar aqui a Lei $\mathrm{n}^{\circ}$ 9.394, de 20 de dezembro de 1996 (Lei de Diretrizes e Bases da Educação Nacional de 1996, vigente no momento atual). Esta lei também representou um marco na legislação brasileira no que se refere ao direito à educação (CORREA, 2007; CORREA, 2011b; GUIMARÃES e 
PINTO, 2001), ao definir a educação infantil como primeira etapa de ensino na educação básica (Art. 21 e Art. 29), em sua versão original:

Art. 21. A educação escolar compõe-se de:

I - educação básica, formada pela educação infantil, ensino fundamental e ensino médio;

II - educação superior (BRASIL, 1996).

Art. 29. A educação infantil, primeira etapa da educação básica, tem como finalidade o desenvolvimento integral da criança até seis anos de idade, em seus aspectos físico, psicológico, intelectual e social, complementando a ação da família e da comunidade (BRASIL, 1996).

Com isso, a educação infantil passa a fazer parte das estruturas regulares de ensino, gerando consequências não apenas quanto ao seu oferecimento, mas também sua normatização e a sua fiscalização (CORREA, 2007). Assim, os princípios para o ensino enumerados na Constituição de 88 - "igualdade de condições para o acesso e permanência na escola" (BRASIL, 1988, Art. 206, inciso I) e "garantia de padrão de qualidade" (BRASIL, 1988, Art. 206, inciso VII) -, passam a se estender também à educação infantil. É também com a lei n ${ }^{\circ}$ 9.394/96 que a educação infantil fica subdividida em duas etapas, sendo a creche ofertada para crianças de 0 a 3 anos, e a pré-escola para crianças de 4 a 6 anos, conforme a redação de 1996, que depois foi alterada.

O direito à educação, conforme afirma Arelaro (2005), não deve ser compreendido apenas como a garantia de uma vaga na escola, e sim em seu aspecto mais amplo de garantia de oferecimento das condições para que todos possam frequentar a escola. $\mathrm{O}$ direito de todos e dever do Estado implica que todos os cidadãos brasileiros - independentemente de gênero, etnia, ou condição financeira - devem ter a possibilidade de "cursar uma escola com boas condições de funcionamento e de competência educacional, em termos de pessoal, material, recursos financeiros e projeto pedagógico" (ARELARO, 2005, p. 1040).

A obrigatoriedade do ensino, por sua vez, não apenas impõe que os pais ou responsáveis matriculem seus filhos nas escolas, mas também implica na responsabilização do Poder Público pela garantia de oferta, sendo responsabilizado inclusive pela sua oferta irregular (ARELARO, 2005). Conforme afirma Rosemberg (2009),

a obrigatoriedade escolar é de responsabilidade do poder público (autoridade competente) e dos pais. Caso seja comprovada sua negligência na oferta regular do ensino fundamental, a autoridade competente poderá ser imputada por crime de responsabilidade (p. 10). 
Tratar o direito à educação como tão somente uma opção da família, na prática, permite que o Estado se omita em assegurar o direito a todos os cidadãos (PINTO e ALVES, 2010). Para Pinto e Alves (2010), “a obrigatoriedade parece ser o único meio de fazer o Estado assegurar, efetivamente, este direito” (p. 221). Nesse sentido, a ampliação do ensino obrigatório assume papel de estratégia para assegurar o direito à educação.

O Plano Nacional de Educação (PNE), aprovado em 2001 pela Lei no 10.172 (BRASIL, 2001), reafirmou a responsabilidade do Poder Público em assegurar o direito à educação, ao estabelecer as metas e diretrizes para a Educação no decênio de 2001 a 2011. Ao dispor sobre o ensino fundamental, afirmava ainda que "o direito ao ensino fundamental não se refere apenas à matrícula, mas ao ensino de qualidade, até a conclusão" (BRASIL, 2001, p. 22-23). Neste sentido, observa-se neste Plano Nacional de Educação a compreensão de que o direito à educação não implica somente na garantia de vaga na escola, mas na oferta de ensino de qualidade e com condições ao acesso, de responsabilidade do Poder Público.

O Plano Nacional de Educação 2001-2011 colocou como prioridade a garantia do ensino fundamental obrigatório de oito anos a todas as crianças de 7 a 14 anos e a ampliação do atendimento nos demais níveis de ensino, prevendo a extensão da escolaridade obrigatória para crianças de seis anos (SANTOS e VIEIRA, 2006). Ao dispor sobre as metas para o ensino fundamental obrigatório, estabelecia como meta "ampliar para nove anos a duração do ensino fundamental obrigatório com início aos seis anos de idade, à medida que for sendo universalizado o atendimento na faixa de 7 a 14 anos" (BRASIL, 2001, p.24).

Posteriormente, em fevereiro de 2006, foi aprovada a Lei 11.274 (BRASIL, 2006a), que altera a obrigatoriedade do ensino ao ampliar a duração do ensino fundamental para nove anos, com matrícula aos seis anos de idade. Com isso, o Brasil passa a ter nove anos de estudo obrigatório. A Lei 11.274/06 e demais legislação sobre o ensino fundamental de nove anos serão discutidos com maior profundidade mais adiante no presente trabalho, no tópico "Legislação e documentos normativos relativos ao ensino fundamental de nove anos".

Neste contexto, se observava uma tendência mundial de aumento do tempo mínimo de escolaridade da população, em função dos movimentos e conquistas por mais direitos sociais aos cidadãos (MORO, 2009). Segundo Craidy e Barbosa (2012),

a ampliação da obrigatoriedade da educação pública e gratuita é uma exigência política de cidadania dos tempos atuais e tem sido objeto de vigorosa pressão dos organismos multilaterais que possibilitam o financiamento da educação nos países periféricos (p. 20-21). 
Conforme afirmam as autoras, o Brasil vinha sendo pressionado no início do século XXI para a ampliação da obrigatoriedade escolar, pois era um dos países da América Latina com menor tempo de estudo obrigatório (CRAIDY e BARBOSA, 2012).

Maria Malta Campos (2007), a partir de análise comparada dos dados da UNESCO publicados em 2007 sobre a duração do ensino obrigatório, verificou que a maioria dos países da América Latina e Caribe definia 10 anos ou mais de duração do ensino obrigatório. Conforme informa a autora, dentre os 41 países da América Latina e Caribe listados no documento da OREALC/UNESCO de 2007, encontravam-se:

- 15 países que definiam 11 anos ou mais de ensino obrigatório;

- 11 países que definiam 10 anos de duração;

- 5 países que definiam 9 anos;

- 3 países que definiam 8 anos de duração para o ensino obrigatório: Honduras, Bolívia, e Brasil (no momento da coleta dos dados);

- 1 país que definia 7 anos de ensino obrigatório (Trinidad e Tobago); e

- 6 países que definiam 6 anos: Haiti, Honduras, Jamaica, Nicarágua, Panamá e Suriname (CAMPOS, 2007).

A partir destes dados, pode-se visualizar que o Brasil encontrava-se abaixo da média quanto à duração do ensino obrigatório em relação aos vizinhos da América Latina e Caribe, antes da lei 11.274/2006. Para Campos (2007),

do ponto de vista de uma política educacional inclusiva, a decisão de estender para nove anos a duração do ensino fundamental e, portanto, também ampliar para nove anos o ensino definido legalmente como obrigatório, deve ser considerada como um avanço, no contexto da realidade latino-americana (p. 3).

Assim, a ampliação do ensino fundamental obrigatório para nove anos de duração contribuiu para que o Brasil melhorasse sua posição em relação aos países latino-americanos quanto aos anos de estudo obrigatório.

No entanto, mesmo com esta ampliação da obrigatoriedade, o país ainda se encontrava muito aquém da maioria dos países vizinhos, que definiam mais de 10 anos de obrigatoriedade escolar (representados por 26 dos 41 países da América Latina e Caribe, segundo dados da UNESCO do ano de 2007). 
Pinto e Alves (2011) analisaram dados mais recentes da UNESCO publicados em 2010, e observaram que mesmo após a ampliação do ensino obrigatório para nove anos de duração, o Brasil estava abaixo da média de todas as regiões do mundo, exceto o Sul e o Oeste Asiático (Afeganistão, Bangladesh, Irã etc.). Além disso, em 2010 o Brasil ainda era um dos últimos em relação aos vizinhos da América Latina, ao lado de Cuba e à frente apenas de Honduras e Bolívia (com oito anos), Jamaica, Trinidad e Tobago (ambos com sete anos), e Haiti, Nicarágua e Suriname (com seis anos de ensino obrigatório) (PINTO e ALVES, 2011).

Neste contexto, foi aprovada em novembro de 2009 a Emenda Constitucional $n^{\circ}$ 59, que alterou a Constituição Federal de modo a tornar obrigatório o ensino para a população de 4 a 17 anos, ampliando a duração da obrigatoriedade escolar para 14 anos de estudo. Ainda em fase de implementação, a EC 59/2009 estipula o ano de 2016 como prazo final para a adaptação dos sistemas de ensino a estas alterações. A Figura 1 mostra a posição do Brasil quanto aos anos de estudo obrigatório em relação às regiões do mundo e alguns países (segundo dados da UNESCO de 2010), apontando sua posição antes da EC 59/2009, com 9 anos de estudo obrigatório, e como ficará sua posição após 2016, com 14 anos de estudo obrigatório.

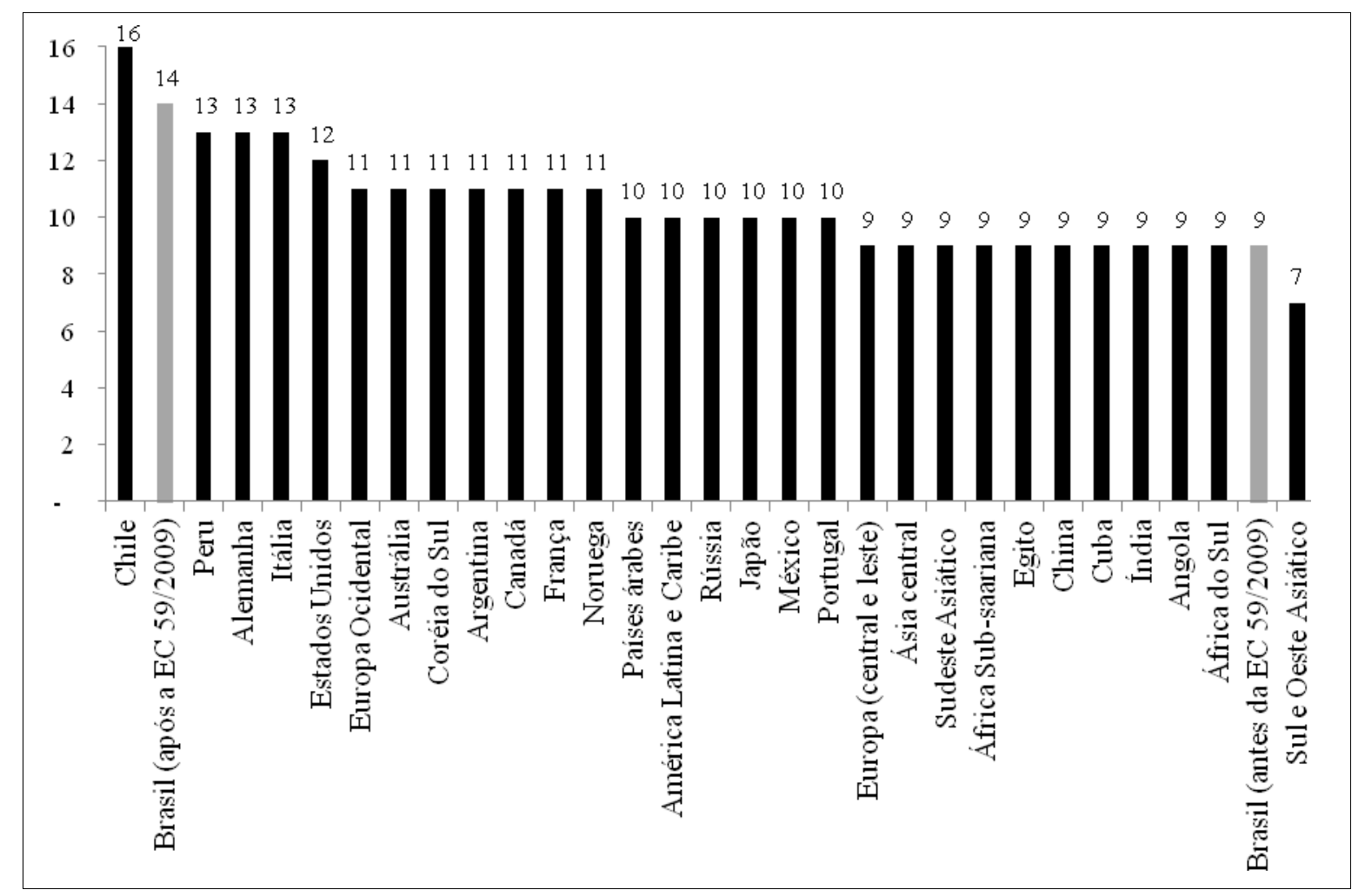

Figura 1. Anos de estudo obrigatório em alguns países e nas regiões do mundo. Fonte: Pinto e Alves (2010), p. 611. 
Os dados apresentados na Figura 1 mostram que o Brasil ficará mais bem posicionado após a EC 59/2009, pois ao estabelecer 14 anos de estudo obrigatório passou a ser o segundo país do mundo neste quesito, ficando atrás somente do Chile, cujo ensino obrigatório abrange a faixa etária dos 5 a 21 anos, somando 16 anos de estudo (PINTO e ALVES, 2011). Como se observa na Figura 1, nenhum país desenvolvido cujo sistema educacional seja considerado de qualidade estabeleceu menos de dez anos de estudo obrigatório (PINTO e ALVES, 2011).

A EC 59/2009 é a mais recente legislação acerca do ensino obrigatório. Ao tornar obrigatório o ensino para a população de 4 a 17 anos, esta Emenda "recupera a lógica instituída pela Constituição Federal de 1967, segundo a qual a obrigatoriedade era definida pela faixa etária das crianças e jovens, e não pela etapa de ensino a ser frequentada" (PINTO e ALVES, 2010; 2011). Conforme visto anteriormente neste tópico, esta lógica havia sido alterada pela Constituição Federal de 1988, em sua versão original, sendo recuperada, de certa forma, pela Emenda Constitucional no 14/ 96.

Nesta lógica da obrigatoriedade por faixa etária, tanto o ensino fundamental como o ensino médio só serão obrigatórios para aquelas crianças e jovens de 6 a 17 anos (PINTO e ALVES, 2010; 2011). Isso implica dizer que, para as crianças e jovens que frequentarem estas etapas da educação básica, mas com idade acima deste limite constitucional, é assegurado o direito ao acesso gratuito à educação e o dever do Estado em fornecer as condições de oferta, mas não se trata de uma obrigação do jovem concluir essas etapas (PINTO e ALVES, 2010; 2011). Portanto, conforme afirmam Pinto e Alves (2010), a EC 59/2009 não assegura que os jovens brasileiros terão acesso e concluirão o ensino médio: Ora, considerando que $34 \%$ dos jovens de 15 a 17 anos que frequentam a
escola o fazem no ensino fundamental, principalmente em virtude da
reprovação, é possível antever que o novo dispositivo constitucional não
assegura, necessariamente, que boa parte dos jovens brasileiros, em
princípio, terá acesso e concluirá o ensino médio, como se poderia pensar (p.
213).

Assim, a existência de uma norma constitucional que disponha sobre o número de anos obrigatórios de estudos não significa, por si só, a garantia de acesso a um ensino de qualidade (PINTO e ALVES, 2010; 2011).

Não obstante, a EC 59/2009 pode se tratar de um avanço no que se refere ao direito à educação, ao implicar na garantia da oferta e de condições de acesso à educação para crianças e jovens que se encontram fora da escola. Conforme afirmam Pinto e Alves (2011), em 2008 
apenas $73 \%$ das crianças de 4 a 5 anos e $84 \%$ dos jovens de 15 a 17 anos tinham acesso à educação, sendo que a taxa de atendimento era ainda menor entre a população mais pobre do país. A Tabela 2, abaixo, elaborada por Pinto e Alves (2010) a partir de microdados da PNAD (Pesquisa Nacional por Amostra de Domicílios) realizada em 2008, mostra a taxa de atendimento escolar por faixa etária para diferentes segmentos de renda:

Tabela 2. Acesso à escola por faixa etária para diferentes segmentos de renda no Brasil em 2008.

\begin{tabular}{l|ccc}
\hline \multirow{2}{*}{ Faixa etária } & \multicolumn{3}{c}{ Taxa de atendimento } \\
\cline { 2 - 4 } & $\begin{array}{c}\text { População na faixa } \\
\text { etária }\end{array}$ & 20\% mais ricos & 20\% mais pobres \\
\hline 4 a 5 anos & $73 \%$ & $89 \%$ & $64 \%$ \\
6 anos & $94 \%$ & $98 \%$ & $90 \%$ \\
7 a 14 anos & $98 \%$ & $99 \%$ & $97 \%$ \\
15 a 17 anos & $84 \%$ & $93 \%$ & $79 \%$ \\
Total & $91 \%$ & $96 \%$ & $89 \%$ \\
\hline
\end{tabular}

Fonte: Pinto e Alves (2010), p. 216.

Quando analisados os números nos segmentos formados pelo nível de renda per capita domiciliar, observa-se na tabela acima que há diferenças expressivas entre a taxa de atendimento dos segmentos da população de $20 \%$ mais ricos e de $20 \%$ mais pobres, exceto para a faixa etária cuja frequência à escola é obrigatória há mais de 40 anos, desde a Constituição de 1967. Mesmo entre as crianças e jovens desta faixa etária (de 7 a 14 anos), é possível verificar na Tabela 2 que a universalização do ensino ainda não havia sido alcançada em 2008.

A Tabela 2 mostra que as taxas de atendimento entre as crianças de 4 a 5 anos e jovens de 15 a 17 anos do segmento de $20 \%$ mais ricos eram maiores que as médias estabelecidas para a população geral nestas faixas etárias, indicando que é no segmento dos $20 \%$ mais pobres que se encontram o maior número de crianças e jovens fora da escola. Para Pinto e Alves (2010), estes dados evidenciam "o quanto a ampliação da obrigatoriedade pode ser útil para amenizar a diferença do acesso entre pobres e ricos" (p. 216), uma vez que "enquanto estamos apenas no campo do direito à educação, esse direito acaba negado aos mais pobres" (PINTO e ALVES, 2011, p. 618). Para os autores, "não há dúvida que somente a rede pública 
poderá garantir o acesso à educação a esta parcela da população que está fora do sistema de ensino" (2011, p. 617).

Assim, como defendem Pinto e Alves (2010; 2011), somente a obrigatoriedade da frequência à escola por parte do aluno pode obrigar, de fato, o Estado a garantir a oferta, em especial aos mais pobres. Portanto, "a ampliação da obrigatoriedade, como estratégia para assegurar o direito à educação, beneficia diretamente às camadas mais pobres da população" (PINTO e ALVES, 2010, p. 215).

Apesar de se constituir uma estratégia para assegurar o direito à educação, a obrigatoriedade do ensino não implica, necessariamente, na expansão de sua oferta. Para Rosemberg (2009), a universalização do acesso à educação escolar se constitui "como uma das metas de implementação do direito à educação escolar - juntamente com a qualidade e a equidade da oferta - e a obrigatoriedade de matrícula/frequência como uma das estratégias para alcançar essa meta” (p. 4).

Segundo a autora, estudos mostram uma pequena associação entre a obrigatoriedade do ensino e a expansão da oferta, como é o caso de alguns países como a Prússia, Dinamarca, Suécia e Japão, em que as leis de obrigatoriedade impulsionaram a expansão da cobertura (ROSEMBERG, 2009). A autora analisa, no entanto, que não há relação direta entre obrigatoriedade e expansão da oferta, e argumenta que estudos em países da América Latina que ampliaram a obrigatoriedade do ensino mostram que não houve a expansão da oferta em grande parte dos casos (ROSEMBERG, 2009).

Com base na análise de dados referentes a 2004 divulgados pela UNESCO em 2006, Rosemberg (2009) verificou que dentre 17 países que atingiram a mais alta taxa de cobertura na educação pré-primária, 16 atingiram tal índice de cobertura sem o apoio de uma legislação que estabelecesse a obrigatoriedade de matrícula/frequência na educação pré-primária. Portanto, para Rosemberg (2009), também na educação pré-escolar não se nota associação linear entre obrigatoriedade de matrícula/frequência e extensão da cobertura (ROSEMBERG, 2009).

Assim, a autora critica que o termo "obrigatoriedade" foi empregado na EC 59/2009 como sinônimo de universalização da oferta. Também analisa que a ampliação da obrigatoriedade para crianças de 4 a 5 anos transmite "a mensagem de que o dever do Estado, presente na Constituição desde 1988, em garantir educação infantil de 0 a 6 anos em creches e 
pré-escolas não tem força para que o Estado garanta a educação infantil" (ROSEMBERG, 2009, p. 53).

A autora afirma ainda que, no contexto da EC 59/2009, “a expansão da obrigatoriedade de matrícula/frequência é, então, usada como estratégia para [...] legitimar a posição do país no continente, conforme pressão de organismos internacionais" (ROSEMBERG, 2009, p. 48). Em análise dos textos oficiais que tratam da ampliação da obrigatoriedade do ensino para a faixa etária de 4 a 17 anos, Rosemberg (2009) afirma que não foi encontrada "qualquer menção a estratégias, mesmo as mais gerais, que previssem como implementar a obrigatoriedade nos 5.651 municípios no país” (p. 54).

Para que haja a expansão da oferta e universalização do ensino, não basta tornar a frequência/matrícula obrigatória, sendo necessário que sejam tomadas medidas que contribuam para aumento da taxa de cobertura na educação. Conforme afirmam Pinto e Alves (2010), ao incluirmos mais alunos no ensino obrigatório, quase a totalidade deles no sistema público, "é evidente que haverá uma demanda adicional de recursos financeiros" (221). Portanto, "a sanção da obrigatoriedade não produz o milagre da ampliação democrática e com qualidade da oferta. Especialmente quando não se dispõe de planos que operacionalizem como e para quem serão alocados os recursos" (ROSEMBERG, 2009, p. 54).

Buscou-se no presente tópico debater as principais considerações acerca da obrigatoriedade do ensino, a partir de uma breve retrospectiva normativa acerca do tema no Brasil e sua contextualização no cenário mundial. Com base no exposto até o momento, conclui-se pela importância da ampliação da obrigatoriedade escolar como forma de obrigar o Estado na garantia de oferta, mas tendo consciência de que esta medida não deve vir desacompanhada de planejamento e criação de condições para a expansão da oferta. Nesse sentido, faz-se relevante a criação de condições de financiamento das novas matrículas sem comprometer a qualidade do ensino. O tópico a seguir trata dos principais mecanismos de financiamento na educação criados nos últimos 20 anos, e sua influência no contexto da ampliação do ensino fundamental obrigatório para nove anos e do ingresso da criança de seis anos nesta etapa de ensino. 


\subsection{O Fundef e a matrícula de crianças de seis anos no ensino fundamental: antecedentes}

Como visto no tópico anterior, ao longo da história da educação brasileira encontramse algumas medidas que visavam a universalização do ensino por meio da ampliação da obrigatoriedade escolar. Para abarcar um maior número de alunos matriculados nas escolas era necessário, portanto, maiores recursos financeiros. É neste contexto de financiamento do ensino obrigatório que foi criado em 1996 o Fundo de Manutenção e Desenvolvimento do Ensino Fundamental e Valorização do Magistério (FUNDEF), a partir da Emenda Constitucional $\mathrm{n}^{\circ} 14$ de setembro de 1996, que subvinculou para o ensino fundamental parte dos recursos constitucionais destinados à manutenção e desenvolvimento do ensino. Esta Emenda foi regulamentada pela Lei ${ }^{\circ} 9.424$ de dezembro de 1996. O Fundef foi implantado de forma compulsória, a partir de $1^{\circ}$ de janeiro de 1998, quando passou a vigorar em todo o país a nova sistemática de redistribuição dos recursos destinados ao ensino fundamental.

Com vigência definida para o período de 1997 até o final de 2006, o objetivo deste fundo era garantir o financiamento do ensino obrigatório no país naquele momento (ensino fundamental). Este fundo representava uma focalização dos gastos educacionais no ensino fundamental obrigatório. Ele era composto com parte dos recursos vinculados à educação dos Estados e Municípios, com pequeno complemento da União para os entes federados cujo valor por aluno não atingisse um patamar mínimo, estabelecendo assim um mecanismo de “redistribuição financeira” (KLEIN, 2011). Esses recursos eram distribuídos entre as redes estaduais e municipais de acordo com o número de matrículas de alunos atendidos no ensino fundamental regular, de forma que, quanto maior o número dessas matrículas, maior seriam os recursos financeiros recebidos pelos entes federados (PINTO, 2000).

Conforme afirma Pinto (2000), apesar de dispor sobre o financiamento da educação, o Fundef não trouxe novos recursos para a educação: "é preciso ficar claro que o Fundef não traz recursos novos para a educação; o que ele faz é criar uma subvinculação para o ensino fundamental dos recursos já existentes" (p. 110). Assim, na prática o Fundef significou um remanejamento de valores que já seriam gastos com educação, não aumentando os investimentos com a área, e mantidas as diferenças regionais (KLEIN, 2011).

A Constituição Federal de 1988 afirmava que a União, os Estados, o Distrito Federal e os Municípios deveriam organizar seus sistemas em regime de colaboração. No entanto, a Constituição determinava, em seu Art. 211 - com alterações dadas pela Emenda 14/96 -, que os municípios deveriam se responsabilizar prioritariamente pela educação infantil e pelo 
ensino fundamental, e que o Distrito Federal e os estados deveriam se responsabilizar prioritariamente pelo ensino fundamental e médio (BRASIL, 1988). Assim, a responsabilidade pela oferta do ensino fundamental ficou dividida entre as entidades municipais e estaduais.

Neste contexto, a partir da criação do Fundef se observa uma intensificação de um movimento de municipalização do ensino fundamental, em que as matrículas no ensino fundamental na rede municipal cresceram muito mais, se comparadas às das redes estaduais (GUIMARÃES e PINTO, 2001). Assim, o Fundef produziu efeito indutor do processo de municipalização das redes de ensino, gerando grande impacto sobre as administrações municipais, sobretudo as mais pobres (ARELARO, JACOMINI e KLEIN, 2011).

Para Pinto (1999; 2000), este processo de municipalização se deu como consequência do repasse de recursos ocorrer de acordo com o número de matrículas no ensino fundamental regular. Sendo os municípios a entidade federada com menos recursos, os governos municipais acreditavam que a melhor forma de receber de volta os recursos retidos pelo Fundo seria transferir para sua rede os alunos da rede estadual:

O motivo desta indução à municipalização feita pelo Fundef é claro: premidos por falta de recursos, os prefeitos ficam altamente sugestionáveis aos argumentos utilizados pelos governos estaduais e defendidos pelo governo federal de que a melhor forma de receber de volta os recursos retidos pelo Fundo é aceitar os alunos da rede estadual, podendo até obter 'lucro' neste processo, recebendo do Fundef mais recursos do que nele depositaram (PINTO, 2000, p. 112).

Dessa forma, se a cada aluno matriculado a rede de ensino correspondia uma determinada quantia de dinheiro, o interesse de matricular mais alunos foi imediato, o que acelerou o processo de municipalização do ensino. No entanto, é evidente que, com maior número de matrículas, maiores eram as despesas, sendo inviável a obtenção de "lucros" por meio desta manobra, até porque os valores repassados por aluno eram muito inferiores ao necessário para se garantir um ensino de qualidade. Além disso, o total de alunos matriculados no município como um todo não se modificava, o que implicava que os valores recebidos pelo fundo, como um todo, não se alterariam (PINTO, 1999; 2000).

A aprovação do Fundef também teve grandes repercussões sobre a matrícula na educação infantil. Segundo Guimarães e Pinto (2001), ao priorizar o financiamento do ensino fundamental, o Fundef desestimulou o financiamento da educação infantil, já que os municípios eram obrigados a investir $60 \%$ dos recursos da educação no ensino fundamental 
(GUIMARÃES e PINTO, 2001). Com isso, houve uma estagnação da oferta da educação infantil, e em alguns casos, até mesmo uma retração desta oferta (ARELARO, 2005; ARELARO, JACOMINI e KLEIN, 2011; CORREA, 2007; CORREA, 2011; GUIMARÃES e PINTO, 2001; PINTO, 1999).

Pode-se dizer, portanto, que o Fundef era uma política de incentivo que visava aumentar as matrículas no ensino fundamental em detrimento das matrículas na educação infantil e outras modalidades de ensino (ARELARO, JACOMINI e KLEIN, 2011). Como afirmam Pansini e Marin (2011), essa valorização de uma etapa específica da escolarização das crianças em detrimento de outra acentuou ainda mais a cisão entre o ensino fundamental e a educação infantil, e fortaleceu a crença de que, quanto mais cedo as crianças ingressarem no ensino fundamental, maiores as chances de que sejam bem-sucedidas na continuidade da escolarização (PANSINI e MARIN, 2011). A esta crença somava-se o fato da destinação de recursos do Fundef considerar o número de matrículas, o que desencadeou um movimento de antecipação da idade de entrada das crianças no ensino fundamental, com vistas a usufruir dos recursos desse fundo (PANSINI e MARIN, 2011).

O ingresso no ensino fundamental aos seis anos de idade encontrava o amparo legal na Lei de Diretrizes e Bases da Educação Nacional (1996), que possibilitava o ingresso aos seis anos, desde que houvesse vagas, ficando a decisão a cargo dos municípios e estados. $\mathrm{O}$ parágrafo $3^{\circ}$ do artigo 87 afirmava:

$\S 3^{\circ}$ Cada Município e, supletivamente, o Estado e a União, deverá:

I - matricular todos os educandos a partir dos sete anos de idade e, facultativamente, a partir dos seis anos, no ensino fundamental (BRASIL, 1996).

Assim, pode-se dizer que a partir do Fundef surge um maior interesse por parte dos municípios em cumprir o disposto no Artigo 87 da LDB, acima citado, levando muitas secretarias de educação a inserirem nas turmas de primeiro ano crianças que ainda não haviam completado sete anos com o intuito de ampliar o volume de recursos a serem recebidos (KLEIN, 2011; PANSINI e MARIN, 2011). Portanto, a antecipação da matrícula das crianças de seis anos no ensino fundamental "representava uma dupla vantagem para as redes municipais, pois, além de aumentar o número de matrículas para recebimento dos recursos oriundos do Fundef, eximiam-se da responsabilidade de ampliar a oferta de EI para essa clientela" (PANSINI e MARIN, 2011, p. 89). 
Com isso, pode-se afirmar que é após a criação do Fundef que a matrícula de crianças com seis anos começa a ser prática generalizada adotada pelos municípios. Guimarães e Pinto (2001) apontam para o salto nas matrículas da rede municipal para o nível do ensino fundamental, com a incorporação das crianças de seis anos:

De 1967 para 1998, enquanto a rede estadual apresentou uma queda de 4,4\% nas matrículas nesse nível de ensino, os municípios tiveram um crescimento de $21,8 \%$, resultando num crescimento médio de 6,2\% nas matrículas da rede pública, índice bem acima da média anual da década anterior. Esse salto pode ser explicado pela incorporação das antigas classes de alfabetização, com forte presença no Nordeste e Rio de Janeiro, no ensino fundamental, assim como das crianças de 6 anos, incentivando-se o seu ingresso precoce neste nível de ensino (GUIMARÃES e PINTO, 2001, p. 99).

Neste movimento de municipalização do ensino acelerado pelo Fundef, encontravamse, em 2006, 60\% dos atendimentos públicos no ensino fundamental que já estavam municipalizados, e do total das matrículas públicas de $1^{\text {a a }} 4^{\text {a }}$ série, $75 \%$ delas já estavam sob responsabilidade municipal, e somente $25 \%$ sob a estadual (ARELARO, JACOMINI e KLEIN, 2011)

Portanto, pode-se dizer que a proposta da redução da idade de matrícula no ensino fundamental para seis anos passou a ser gestada a partir da consolidação do processo de municipalização, intensificado com o Fundef (ARELARO, JACOMINI e KLEIN, 2011). Para Klein (2011), "pode-se afirmar que a matrícula das crianças de seis anos no EF e o ensino fundamental de nove anos foram gestados nos marcos do FUNDEF, onde os interesses econômicos sobrepunham-se aos pedagógicos" (p. 69). Dessa forma, a política do ensino fundamental de nove anos pode ser compreendida como integrando este movimento de antecipação da idade da matrícula no ensino fundamental, que passou a ser praticada com maior frequência a partir do Fundef e do processo de municipalização do ensino.

Esta influência do Fundef na antecipação da matrícula no ensino fundamental para crianças de seis anos de idade é reconhecida e citada no Parecer no 24 de 2004 (BRASIL, 2004c) e seu reexame dado pelo Parecer $n^{\circ} 6$ de 2005 (BRASIL, 2005b):

A antecipação da matrícula no Ensino Fundamental de crianças de seis anos, com reconhecidas exceções, em muitos sistemas municipais, não visou necessariamente à melhoria da qualidade, mas, de fato, aos recursos do FUNDEF, uma vez que o aluno passou a ser considerado como "unidade monetária" (haja vista as situações em que o Ensino Fundamental foi mantido com oito anos de duração). (PARECER CNE/CEB N. 06/2005, p. 7). 
Em verdade, já em 1998 o Conselho Nacional de Educação/Câmara de Educação Básica (CNE/CEB) emitiu Parecer que tratava da ampliação do ensino fundamental para nove anos em vistas a incluir nesta modalidade de ensino as crianças de seis anos. O Parecer CNE/CEB no 20/98 (BRASIL, 1998) tratava de uma consulta, feita pelo Presidente do Instituto Nacional de Estudos e Pesquisas Educacionais Anísio Teixeira (INEP) sobre a possibilidade do município de Porto Velho (RO) ampliar a duração do ensino fundamental para nove anos (KLEIN, 2011). Inicialmente, tratando dos contornos legais, o Parecer admitia que a LDB era flexível em relação à duração do ensino fundamental, assim como em relação a idade de ingresso nesta etapa de ensino, afirmando que "a lei não desce ao detalhe do que se deva entender por seis ou sete anos, completos ou a completar na data da matrícula ou no ano letivo" (BRASIL, 1998a). Na sequência, abordava a questão da matrícula das crianças de seis anos no ensino fundamental, demonstrando conhecimento dos interesses econômicos nesta manobra, e posicionando-se criticamente:

Cabe à Câmara de Educação Básica esclarecer as autoridades educacionais, tanto normativas como executivas, sobre matéria tão relevante que não pode tornar-se objeto de políticas dúbias, ou mesmo oportunistas, que em nome do legalmente possível ou do financeiramente rentável possam resultar em constrangimentos administrativos e pedagógicos que redundem em menor qualidade de aprendizagem para as crianças de seis anos, exatamente numa idade em que o processo de alfabetização precisa estar resguardado pela competência gerencial e pedagógica. O Conselho Nacional de Educação é guardião, inclusive, de valores historicamente construídos na oferta da educação infantil por Estados e Municípios, assim como de conquistas e avanços pedagógicos na organização do Ensino Fundamental que não podem ser destruídos pela tentação de disputa ou competição de redes estaduais ou municipais por matrículas que neste momento se transformam em verbas do FUNDEF para este ou aquele ente federativo (BRASIL, 1998, grifo nosso).

Dessa forma, é possível observar que já em 1998 eram conhecidos os efeitos do Fundef sobre a antecipação da matrícula das crianças de seis anos no ensino fundamental e ampliação desse nível de ensino para nove anos, com vistas a usufruir dos recursos do Fundef.

Apesar de apresentar crítica à intenção da ampliação do ensino fundamental com base em interesses econômicos, o Parecer citado afirmava que grande parte das crianças de seis anos já se encontravam no ensino fundamental, mesmo antes da aprovação do Fundef. O Quadro 3, abaixo, é apresentado no referido documento para mostrar onde estavam matriculadas as crianças de seis anos, comparando-se os anos de 1996 e 1998 : 
Quadro 3: Matrícula das crianças de seis anos de idade em 1996 e 1998

\begin{tabular}{|l|r|r|r|}
\hline & 1996 & 1998 & \multicolumn{1}{|l|}{ Diferença } \\
\hline Educação Infantil & 1.500 .033 & 1.484 .904 & -15.129 \\
\hline Classes de Alfabetização & 481.179 & 389.940 & -91.239 \\
\hline Ensino Fundamental & 342.376 & 451.825 & +109.449 \\
\hline
\end{tabular}

Fonte: Parecer nº 20/98 (BRASIL, 1998a).

É possível observar no Quadro 3 que com o Fundef houve um aumento significativo das matrículas das crianças de seis anos no ensino fundamental, em comparação com as classes de alfabetização e a educação infantil. O documento pontua que "com a implantação do FUNDEF a tendência é a de muitos municípios assumirem o ensino fundamental e neste caso, com a conveniência imediata de antecipá-lo para os seis anos, o que socializa com mais equidade os recursos financeiros do FUNDEF" (BRASIL, 1998).

No entanto, a partir dos dados do Quadro 3, o Parecer afirmou que “independentemente da implantação do FUNDEF, que em 1998 pode ter acelerado as mudanças, milhares de famílias já matriculavam seus filhos de seis anos no ensino fundamental" (BRASIL, 1998). O documento afirmava, ainda, que isso refletia uma tendência natural de maior porcentagem de matrículas de crianças de seis anos na escola, e que era "quase unânime a percepção dos pedagogos, confirmada pela experiência internacional, que a "idade própria" do início da alfabetização é a de seis e não de sete anos” (BRASIL, 1998).

Assim, apesar da crítica à intenção de alguns municípios de matricular as crianças de seis anos e ampliar o ensino fundamental com vistas a usufruir dos recursos do Fundef, "em nome do legalmente possível e do financeiramente rentável" (BRASIL, 1998a), o Parecer $n^{\circ}$ 20/98 parece legitimar a matrícula das crianças de seis anos no ensino fundamental, definindo como possíveis tanto a matrícula das crianças de seis anos no ensino fundamental, quanto a ampliação desta etapa para nove anos.

A "tendência natural" e a "experiência internacional" a que se remete o Parecer $\mathrm{n}^{\circ}$ 20/98 parecem fazer referência a um contexto internacional de antecipação da matrícula de crianças de seis anos no ensino obrigatório. Maria Malta Campos (2007), a partir de análise comparada dos dados da UNESCO sobre a idade de ingresso no ensino obrigatório, afirma que na maioria dos países o início da escola primária ocorre aos seis anos de idade, e que isso ocorre já há muito tempo. Mesmo considerando apenas a América Latina e o Caribe, eram poucos os países que ainda mantinham o ingresso aos sete anos no início dos anos 2000 
(CAMPOS, 2007). Conforme informa a autora, dentre 41 países da América Latina e Caribe listados em documento da OREALC/UNESCO de 2007, encontravam-se:

- 22 países em que o início da educação obrigatória era aos 6 anos;

- 15 países em que o início da educação obrigatória era aos 5 anos;

- e apenas 4 países em que o início da educação obrigatória era aos 7 anos, incluindo o Brasil $^{5}$ (CAMPOS, 2007).

Assim, o Brasil, juntamente com El Salvador, Guatemala e Nicarágua eram os únicos país da América Latina e Caribe em que a idade inicial para escolaridade obrigatória era de 7 anos (CAMPOS, 2007).

Para Santos e Vieira (2006) e Gorni (2007), estes dados são indícios de que o ingresso de crianças mais novas no ensino obrigatório faz parte de uma tendência mundial de aceleração e segmentação da infância (SANTOS e VIEIRA, 2006; GORNI, 2007). Segundo Bertini et al. (2008), o Banco Mundial determinava aos países a ampliação do ensino, iniciando esta tendência internacional: "as políticas desenvolvimentistas do Banco Mundial determinam e orientam para uma educação que inclua a todos e que o tempo de permanência na escola seja ampliado de alguma forma" (p. 66).

O Plano Nacional de Educação de 2001-2011 (BRASIL, 2001), ao estabelecer como meta "ampliar para nove anos a duração do ensino fundamental obrigatório com início aos seis anos de idade" (BRASIL, 2001), apontou como justificativa a possibilidade de correção de uma distorção idade-série e de equiparar o Brasil em relação aos demais países quanto à idade de ingresso no ensino fundamental. Conforme afirma o texto da lei,

A correção dessa distorção abre a perspectiva de, mantendo-se o atual número de vagas, ampliar o ensino obrigatório para nove séries, com início aos seis anos de idade. Esta medida é importante porque, em comparação com os demais países, o ingresso no ensino fundamental é relativamente tardio no Brasil, sendo de seis anos a idade padrão na grande maioria dos sistemas, inclusive nos demais países da América Latina. Corrigir essa situação constitui prioridade da política educacional (BRASIL, 2001, p. 22, grifo nosso).

Esta justificativa induz à compreensão de que a política de ampliação do ensino fundamental para nove anos teve, em sua origem, o objetivo de inserir o Brasil em um movimento de âmbito internacional relacionado à educação. Assim, acreditava-se que a

\footnotetext{
${ }^{5}$ Dados referentes ao momento da coleta dos dados pela UNESCO, publicados em 2007.
} 
política do ensino fundamental de nove anos melhoraria a posição do Brasil em relação à idade de ingresso no ensino obrigatório quando comparado aos países vizinhos (CAMPOS, 2007).

Para Arelaro (2005), a existência de uma tendência internacional em antecipar o ingresso no ensino obrigatório não justifica que tal medida seja adotada no Brasil:

É verdade que um número significativo dos países europeus, especialmente os mais avançados do ponto de vista socioeconômico, adota, de forma razoavelmente generalizada, o ingresso das crianças, na escola formal, entre 5 e 6 anos de idade. É verdade também que a maioria desses países não defende uma Lei Nacional de Diretrizes e Bases em que esteja proposto, como primeira etapa educacional, educação infantil de 0 a 6 anos de idade (ARELARO, 2005, p. 1046).

Assim, esta tendência pode ser contestada se pensarmos que nossas conquistas históricas da educação infantil enquanto direito e enquanto etapa da educação básica se mostram mais avançadas do que em outros países, mesmo que estes possuam índices de matrícula superiores aos nossos (KLEIN, 2011). Abramowicz (2006) complementa que "as lutas históricas dos movimentos sociais em favor da criança pequena sempre estiveram vinculadas à luta pela ampliação da Educação Infantil como direito da criança, dever do Estado e escolha da família" (p. 318). Dessa forma, levando-se em conta a realidade brasileira de lutas e reivindicações pela educação infantil, a matrícula de crianças de seis anos no ensino fundamental para acompanhar uma tendência internacional significa um desrespeito às conquistas alcançadas.

A inclusão da educação infantil no sistema de financiamento da educação foi uma destas conquistas, que culminou com a criação do Fundo de Manutenção e Desenvolvimento da Educação Básica e de Valorização dos Profissionais da Educação - Fundeb, pela Emenda Constitucional n ${ }^{\circ} 53$ de 2006 (BRASIL, 2006c), e regulamentado pela Lei no 11.494 de 2007 (BRASIL, 2007d), em substituição ao Fundef. Com vigência estabelecida para o período 2007-2020, o Fundeb incluiu todas as etapas e modalidades da educação básica: educação infantil, ensino fundamental e ensino médio.

Segundo Pinto (2007), a maior importância do Fundeb é ter resgatado o conceito de educação básica como um direito. Representa também um avanço por definir um prazo para aprovação do Piso Salarial do professor, e inova por prever a criação de uma porcentagem de recursos da União a ser destinada a criação de programas de melhoria da educação (PINTO, 2007). Porém, um retrocesso do Fundeb em relação ao Fundef é que este não estabelece de 
forma mais precisa o custo-aluno qualidade, que vise garantir um padrão básico de qualidade do ensino (PINTO, 2007). No Fundeb, o valor mínimo por aluno é referenciado na complementação da União e não em qualquer critério de equidade ou de qualidade.

Além disso, o Fundeb manteve a mesma lógica do Fundef quanto à distribuição de recursos de acordo com o número de matrículas. Segundo Arelaro, Jacomini e Klein (2011), o problema desta lógica é que o cálculo é feito considerando exclusivamente o número de alunos matriculados no ano anterior. Assim, se os estados e municípios matricularem um número significativamente maior de aluno que no anterior, o valor aluno/ano poderá ser menor.

Ainda comparando-se o Fundeb com o Fundef, mesmo contando com maior recurso financeiro, o Fundeb não representou um avanço quanto ao valor médio gasto por aluno, como bem explica Pinto (2007):

\begin{abstract}
Quando se considera, inclusive, o valor médio por aluno, a tendência com o FUNDEB é haver uma diminuição perante o valor propiciado pelo FUNDEF, mesmo levando em conta um aumento superior a 10 vezes (de R\$ 314 milhões, em 2006, para R \$ 4,5 bilhões, em 2009) o da complementação da União [...]. Isso se explica porque, mesmo considerando que o FUNDEB envolverá recursos totais $43 \%$ superiores àqueles abrangidos pelo FUNDEF, tomando por base o ano de 2006, o número de alunos atingidos pelo novo fundo será $61 \%$ superior (p. 886).
\end{abstract}

Dessa forma, apesar do Fundeb resgatar o conceito de direito à educação básica ao incluir diferentes etapas e modalidades da educação básica, pode-se afirmar que este fundo não representou um avanço quanto ao valor médio por aluno.

Para Arelaro, Jacomini e Klein (2011), esta nova extensão do financiamento para a educação infantil não parece ter sido considerada ao ser proposta a política do ensino fundamental de nove anos, com a Lei 11.274 de 2006. Para Saviani (2011), os interesses econômicos que influenciaram esta política perderam-se com o fim do Fundef: a "motivação perdeu razão de ser com a substituição do Fundef pelo FUNDEB, já que este passou a abranger toda a Educação Básica, incluindo, portanto, também a Educação Infantil na sua integralidade" (p.84).

Como mostram Oliveira e Teixeira (2009), a Proposta de Emenda Constitucional que posteriormente deu origem a Emenda 53/2006 é datada de $2005\left(\mathrm{PEC} \mathrm{n}^{\circ}\right.$ 415/2005), anterior à Lei 11.274/2006. Assim, ainda que a proposição do ensino fundamental de nove anos tenha se iniciado anteriormente, com o Fundef ainda em vigor, esta política deveria ter sido alvo de 
debates de forma mais intensa antes de sua aprovação por lei, visto que já existia como Proposta de Emenda Constitucional um Fundo que incluísse a educação infantil.

No entanto, conforme esclarecem Arelaro, Jacomini e Klein (2011), o fator de ponderação do Fundeb para a distribuição dos recursos de acordo com o número de matrículas era menor em $10 \%$ para a pré-escola. Dessa forma, "o sistema de ensino recebia, para a mesma criança de 6 anos matriculada na pré-escola, 10\% a menos do que_receberia de ela estivesse matriculada no ensino fundamental" (ARELARO, JACOMINI e KLEIN, 2011, p. 41).

Ainda, na versão final do novo fundo foram incluídas as matrículas da educação infantil da rede conveniada sem fins lucrativos. Segundo Pinto (2007),

essa inclusão, que representa um duro golpe no princípio de que recursos públicos devem se destinar às instituições públicas, decorreu da constatação de que um número significativo de prefeituras mantém convênios com aquelas instituições e sua exclusão significaria deixar milhares de crianças sem atendimento (p. 888).

No entanto, os valores de ponderação estabelecidos pelo Fundeb para rede conveniada eram ainda menores do que os valores definidos para a rede pública (PINTO, 2007; CORREA, 2011b). O grande risco, em especial no que se referia às creches, era que o crescimento das matrículas se desse pela via das instituições conveniadas, já que o repasse que do poder público a essas instituições é muito inferior aos custos do atendimento direto (PINTO, 2007).

Portanto, ainda que o Fundeb tenha incluído a educação infantil, manteve o financiamento para esta modalidade de ensino inferior ao ensino fundamental, privilegiando seu crescimento por meio das redes conveniadas, com baixo custo. Assim, em vez de aumentar os recursos destinados à educação infantil e melhorar as condições de oferta desta modalidade de ensino, optou-se por inserir as crianças de seis anos no ensino fundamental, que já contava com maiores recursos. Além disso, acrescentavam-se as especificidades da educação infantil, que recomendam que as classes/turmas sejam constituídas, no caso das crianças de seis anos, com 20 alunos (ARELARO, JACOMINI e KLEIN, 2011). Nesse sentido, a educação infantil permanecia, como um todo, prejudicada. Com isso, pode-se afirmar que "a distribuição de recursos para os diferentes níveis educacionais, historicamente, tem discriminado a EI [educação infantil], a criança pequena” (ROSEMBERG, 2010, p. 5). 
Portanto, observa-se que a política do ensino fundamental de nove anos teve motivações econômicas incentivadas pelo Fundef, que não se alteraram com o Fundeb, além de se inserir num movimento mundial de antecipação da idade de ingresso no ensino obrigatório. Viu-se no presente tópico os principais antecedentes da política do ensino fundamental de nove anos, contextualizando o momento histórico em que esta política passou a ser gestada. Compreendida a influência destes antecedentes na política do ensino fundamental de nove anos, será discutida a seguir a legislação que fundamenta esta política.

\subsection{Legislação e documentos normativos relativos ao ensino fundamental de nove anos}

Até o momento, foram apresentados os marcos políticos e legais que contextualizam a política do ensino fundamental de nove anos, em que foram discutidos os movimentos de ampliação da duração da obrigatoriedade escolar e a antecipação da matrícula no ensino obrigatório para crianças de seis anos no Brasil, situando-o no quadro mundial. Compreendidos estes marcos que influenciaram a política do ensino fundamental de nove anos, passa-se agora a discutir de forma mais focada esta política, apresentando os principais instrumentos legais que a fundamentam.

Como afirmado anteriormente, com a centralização do financiamento para o ensino fundamental e com a flexibilidade dada pela LDB, muitos sistemas de ensino passaram a matricular as crianças de seis anos no ensino fundamental e, em menor escala, a ampliar esta etapa de ensino para nove anos de duração. Tendo sido estabelecida como meta no PNE de 2001, a ampliação do ensino fundamental para nove anos passou a ser estudada pela Secretaria de Educação Básica/Ministério da Educação, mediante a criação do Programa Ampliação do Ensino Fundamental para Nove Anos. O Ministério da Educação iniciou as ações do programa com a realização de encontros regionais com os sistemas interessados na ampliação. Assim, no início de 2004 foram realizados sete encontros regionais com diversos sistemas de ensino, em que várias questões relativas à ampliação desta etapa de ensino foram levantadas e discutidas pelos gestores.

A partir das contribuições dos participantes destes encontros regionais, foi elaborado pela Secretaria de Educação Básica (SEB)/Departamento de Políticas de Educação Infantil e Ensino fundamental (DPE)/Coordenação Geral do Ensino Fundamental (COEF) o documento Ensino fundamental de Nove Anos: orientações gerais (BRASIL, 2004a), publicado ainda no 
ano de 2004. Segundo o próprio Ministério da Educação, este documento "é referência nacional para questões pedagógicas, administrativas e de avaliação no que se refere à inclusão das crianças de seis anos no ensino fundamental” (BRASIL, 2004b).

Este documento apresentava um breve histórico dos estudos e encontros realizados para a discussão do tema, e apresentava orientações direcionadas no sentido de uma construção de uma política pública com qualidade:

O MEC/SEB/DPE/COEF pretende, com estas orientações, construir políticas indutoras de transformações significativas na estrutura da escola, na reorganização dos tempos e dos espaços escolares, nas formas de ensinar, de aprender, de avaliar, implicando a disseminação das novas concepções de currículo, conhecimento, desenvolvimento humano e aprendizado. (BRASIL, 2004a, p. 11).

As orientações e reflexões contidas neste documento apontam para a necessidade de construção de uma escola comprometida com a cidadania que caminhe para uma real inclusão do aluno. Conforme afirmado no documento, "a construção dessa escola demanda, certamente, mais do que políticas promotoras do acesso à escola" (BRASIL, 2004a, p. 11). Assim, o documento aponta para a necessidade de debate e reorganização do currículo tradicional da escola, dentro de um movimento de renovação pedagógica.

De acordo com o documento do Ministério da Educação, aquele era um momento em que vários sistemas de ensino estaduais e municipais já organizavam o ensino fundamental com nove anos de duração, uma vez que a legislação 'abria brechas' para tal (BRASIL, 2004a). Conforme é afirmado no documento, a Secretaria de Educação Básica realizou estudos e pesquisas nos estados e municípios brasileiros que já adotavam o ensino fundamental com duração de nove anos por iniciativa própria. Segundo o Ministério da Educação, apenas seis das 27 unidades federativas do Brasil não apresentavam nenhuma forma de ampliação do ensino fundamental até 2003:

O Censo Escolar de 2003 (INEP/MEC) aponta que o Ensino Fundamental de oito anos vigorava em 159.861 escolas públicas brasileiras, mas 11.510 escolas já haviam ampliado o Ensino Fundamental para nove anos. Apenas seis unidades da Federação - Acre, Mato Grosso do Sul, Rio Grande do Norte, Rondônia, Roraima, Sergipe - não apresentavam nenhum tipo de ampliação do Ensino Fundamental até 2003. Segundo levantamento feito pela SEB/MEC, os sistemas estaduais de Minas Gerais, Goiás, Amazonas, Sergipe e Rio Grande do Norte iniciaram a ampliação do Ensino 
Fundamental em 2004. O Maranhão deverá ampliar em 2005. (BRASIL, 2004b, p. 1).

Os estudos realizados pela SEB/MEC nos sistemas que já haviam ampliado o ensino fundamental faziam parte das ações desenvolvidas pelo Programa Ampliação do Ensino Fundamental para Nove Anos, e contribuíram para subsidiar a elaboração dos documentos orientadores dessa política pública. As ações realizadas pelo Programa até julho de 2004 são apresentadas no primeiro relatório do programa, intitulado Ampliação do ensino fundamental para nove anos: relatório do Programa (BRASIL, 2004b). O relatório resume e sistematiza os temas discutidos nos encontros regionais de 2004, apontando também os questionamentos e sugestões colocadas pelos participantes em tais encontros sobre aspectos que deveriam ser abordados no documento de orientações gerais (BRASIL, 2004b).

O primeiro relatório reafirma a necessidade de renovação pedagógica para implantação do ensino fundamental de nove anos apontada pelo documento Ensino fundamental de Nove Anos: orientações gerais (BRASIL, 2004a), e acrescenta que este movimento devia incluir também a Educação Infantil, reconhecendo que o ingresso das crianças de seis anos no ensino fundamental resultaria em implicações também para esta etapa de ensino:

Os processos educativos precisam ser adequados à faixa etária das crianças ingressantes para que a transição da Educação Infantil para o Ensino Fundamental aconteça sem rupturas traumáticas para elas.

A ampliação tem implicações, que não podem ser subestimadas, em vários aspectos: proposta pedagógica, currículo, organização dos espaços físicos, materiais didáticos e aspectos financeiros. Também repercute sobre a Educação Infantil, pois as diretrizes em vigor para esta etapa precisarão ser reelaboradas (BRASIL, 2004b, p. 1).

Mediante esta necessidade de se atentar para as implicações da ampliação do ensino fundamental com ingresso aos seis anos é que foram realizados os encontros regionais, com o intuito de "discutir com estados e municípios como implementar esta ampliação" (BRASIL, 2004b, p. 1, grifo nosso). De acordo com o documento, "uma consulta feita pela SEB/MEC, em 2003, mostrou que, apesar do interesse de muitas secretarias em ampliar o Ensino Fundamental para nove anos, elas aguardavam definições sobre recursos financeiros e outros aspectos para tomar esta decisão" (Brasil, 2004b, p. 3). Conforme o relatório, os encontros regionais realizados em 2004 tiveram como objetivos: 
a) Trazer para estudo conjunto dos dirigentes e técnicos do Ministério da Educação, dos estados e dos municípios, as questões centrais que envolvem a ampliação do Ensino Fundamental, considerando as crianças de seis anos de idade como novos sujeitos da escolaridade formal obrigatória.

b) Promover o conhecimento e o intercâmbio de experiências bem-sucedidas durante o processo de ampliação do Ensino Fundamental para nove anos.

c) Apresentar e aperfeiçoar a proposta de acompanhamento e avaliação dessa iniciativa (Brasil, 2004b, p. 3).

Portanto, é possível afirmar que os encontros regionais tiveram como objetivo discutir como implementar a política do ensino fundamental de nove anos, e não discutir a política em si. Naquele momento, a discussão sobre a ampliação da obrigatoriedade do ensino já estava definida em torno do ensino fundamental de nove anos, com a matrícula obrigatória aos seis anos de idade. Nas discussões, não há menção sobre tornar obrigatório o último ano da educação infantil, onde a maior parte das crianças de seis anos já estava matriculada, conforme vimos no tópico anterior (ARELARO, JACOMINI e KLEIN, 2011).

No ano seguinte, em 9 de maio de 2005, foi aprovada a Lei $\mathrm{n}^{\circ} 11.114$ (BRASIL, $2005^{\mathrm{a}}$ ), que alterou os artigos $6^{\circ}, 30,32$ e 87 da LDB, com o objetivo de tornar obrigatório o início do ensino fundamental aos 6 anos de idade. Esse ato legal estabeleceu que a lei entraria em vigor já no início do ano letivo seguinte, ou seja, em 2006. Apesar das discussões até o momento envolverem a ampliação do ensino obrigatório, esta lei, no entanto, não estabelecia a ampliação da duração do ensino fundamental de oito para nove anos (BRASIL, 2005a). Assim, com a Lei ${ }^{\circ}$ 11.114/2005 ficava estabelecido o ingresso no ensino obrigatório aos seis anos, sem ampliar sua duração ou prever quaisquer modificações nesta etapa de ensino.

Conforme afirma Arelaro (2005), esta lei "não foi discutida sequer pelo Conselho Nacional de Educação (CNE)" (p. 1047), e acabou por representar sérios problemas para a educação. Segundo a autora, ao vetar o Art. 30, que estabelece que "a educação infantil será oferecida em: I - creches, ou entidades equivalentes, para crianças de até três anos de idade; II - pré-escolas, para as crianças de quatro a seis anos de idade" (BRASIL, 1996, Art.30), a Lei $\mathrm{n}^{\mathrm{o}} 11.114 / 05$ deixa sem especificação quais seriam as instituições educacionais responsáveis pelo atendimento na educação infantil. Assim, a lei prevê que as mudanças deveriam entrar em vigor já em 2006, sem definir, no entanto, se a educação infantil seria destinada às crianças de 0 a 5 anos.

Para Arelaro (2005), ao redigir a Lei $\mathrm{n}^{\circ} 11.114$, "o autor parece ter pretendido transferir, simplesmente, o último ano da educação infantil, incorporando-o ao ensino fundamental, como se isso fosse uma passagem tranquila e as duas instâncias educacionais 
fossem semelhantes" (p. 1047). A autora alerta que ainda era, no ano de 2005, significativo o número de escolas de $1^{\mathrm{a}}$ a $4^{\mathrm{a}}$ série que se mantinham sob responsabilidade estadual e que precisariam incorporar as crianças de seis anos da rede municipal que frequentavam a educação infantil, sem necessariamente haver vagas disponíveis, equipamento ou material pedagógico indicado para as crianças de seis anos. Para Craidy e Barbosa (2012), esta lei

foi aprovada sem que houvesse uma adequação do sistema de ensino, e todos (secretarias estaduais e municipais assim como escolas públicas e privadas) foram induzidos a receber as crianças que estavam fora da escola sem ter conseguido preparar seus professores, os pais, e as próprias crianças (p. 25).

Não obstante, a lei foi aprovada sem que houvesse discussão sobre a proposta, e sem se atentar às implicações e necessidades advindas com o ingresso da criança de seis anos no ensino fundamental, citadas pelo próprio Ministério da Educação nos documentos de orientações gerais e no primeiro relatório. Assim,

um representante do Congresso Nacional teve o poder de modificar uma situação que afeta milhões de pessoas: crianças, pais, educadores e gestores. Uma reforma dessa natureza deveria ser precedida não apenas por debates e estudos que pudessem justificá-la, mas também por uma cuidadosa preparação (CRAIDY e BARBOSA, 2012, p. 19).

Como nenhuma outra providência complementar foi proposta, infere-se que a lei só tenha pretendido ampliar a possibilidade de uso dos recursos do Fundef com crianças menores (ARELARO, 2005), e com isso regulamentar uma situação que já vinha sendo bastante praticada após o Fundef: a matrícula de crianças de seis anos no ensino fundamental, como se discutiu no tópico anterior. Como afirma Arelaro (2005), "portanto, o atendimento às crianças matriculadas na educação infantil passaria a ser realizado "disfarçado" de ensino fundamental" (p. 1047).

Assim, dado o contexto pode-se afirmar que essa lei não pretendia a instalação de um ensino fundamental de nove anos, conforme era proposto no Plano Nacional de Educação, mas, simplesmente, o início desse ensino aos seis anos de idade (ARELARO, 2005). Correa (2007) aponta que, na prática, esta medida "significava não um ganho, mas um prejuízo à boa parte das crianças brasileiras, já que cerca de $75 \%$ delas já estariam sendo atendidas em préescolas”. (p. 5). Desta forma, segundo a autora, as crianças estariam perdendo um ano de escolaridade, uma vez que sairiam mais cedo da educação infantil para ingressarem aos seis anos no ensino fundamental (CORREA, 2007). 
No mês seguinte, em 8 de junho de 2005, o Conselho Nacional da Educação/Câmara de Educação Básica emitiu o Parecer n ${ }^{\circ} 6$ de 2005 (BRASIL, 2005b), que se trata de reexame do Parecer $n^{\circ}$ 24/2004. Em seu texto, era afirmado que "todas as situações em que foi admitida a antecipação da matrícula no Ensino Fundamental para crianças de 6 (seis) anos de idade, esta medida esteve associada à ampliação da duração desta etapa de ensino para 9 (nove) anos" (BRASIL, 2005b). Interessante notar que esta informação não constava em nenhum outro documento emitido até o momento, surgindo, portanto, apenas após a Lei 11.114/2005, aparentemente como uma forma de justificar a aprovação da matrícula de crianças de seis anos no ensino fundamental sem ampliar para nove anos. Em relação ao ingresso da criança no Ensino Fundamental aos seis anos de idade, o Parecer CNE/CEB no 6/2005 esclarece que o objetivo dessa medida é "oferecer maiores oportunidades de aprendizagem no período da escolarização obrigatória e assegurar que, ingressando mais cedo no sistema de ensino, as crianças prossigam nos estudos alcançando maior nível de escolaridade" (BRASIL, 2005b, p. 22).

Para tentar resolver as questões que ficaram pendentes com a Lei 11.114, o CNE/CEB editou a Resolução $n^{\circ} .3$ de 3 de agosto de 2005 (BRASIL, 2005c), que definia normas nacionais para a ampliação do ensino fundamental para nove anos de duração, com início aos seis anos de idade (BRASIL, 2005c). Esta resolução determinava que a matrícula de crianças de seis anos no ensino fundamental implicava na ampliação desta etapa de ensino para nove anos de duração. Assim, como afirmam Pansini e Marin (2011), esta Resolução visava minimizar os efeitos da Lei 11.114 .

O documento definiu a nomenclatura a ser adotada em âmbito nacional, estabelecendo como "anos iniciais" o período compreendido entre $1^{\circ}$ e $5^{\circ}$ ano do ensino fundamental, e “anos finais" o período entre $6^{\circ}$ e $9^{\circ}$ ano (BRASIL, 2005c). A Resolução definiu também o atendimento da pré-escola para crianças de 4 e 5 anos (BRASIL, 2005c). Esta nova organização e a faixa etária atendida pode ser vista no Quadro 4, contido na Resolução $n^{\circ} 3$ de 2005: 
Quadro 4: Organização do ensino fundamental e da educação infantil.

\begin{tabular}{|c|c|c|}
\hline Etapa de ensino & Faixa etária prevista & Duração \\
\hline Educação Infantil & até 5 anos de idade & \\
Creche & até 3 anos de idade & \\
Pré-escola & 4 e 5 anos de idade & $\mathbf{9}$ anos \\
\hline Ensino Fundamental & até $\mathbf{1 4}$ anos de idade & 5 anos \\
Anos iniciais & de 6 a 10 anos de idade & 4 anos \\
Anos finais & de 11 a 14 anos de idade & \\
\hline
\end{tabular}

Fonte: Resolução n 3 de 2005 (BRASIL, 2005c).

Esta organização do ensino fundamental é reafirmada no documento seguinte emitido pelo CNE/CEB: o Parecer no 18/2005 (BRASIL, 2005d), aprovado em 15 de setembro de 2005. Este Parecer trazia orientações para a matrícula de crianças de seis anos, mantendo a orientação dada na Resolução $n^{\circ}$ 3/2005 de que esta medida devia vir acompanhada da ampliação do ensino fundamental para nove anos. O Parecer afirmava que a antecipação da obrigatoriedade de matrícula e a ampliação da duração do ensino obrigatório eram "antigas e importantes reivindicações no campo das políticas públicas de educação, no sentido da democratização do direito à educação" (BRASIL, 2005d, p. 1). Assim, este parecer apresentava críticas à Lei 11.114/2005 por prever apenas uma destas medidas: "no entanto, o processo político-legislativo precipitou uma destas medidas - apenas a da obrigatoriedade de matrícula no Ensino Fundamental aos seis anos -, de forma incompleta, intempestiva e com redação precária" (BRASIL, 2005d, p. 1).

É interessante notar que, enquanto o Parecer 06/2005, aprovado em junho, parecia argumentar a favor da Lei 11.114 justificando a medida ao afirmar que todas as situações em que a matrícula de crianças de seis anos foi admitida no ensino fundamental houve a ampliação desta etapa de ensino para nove anos, o Parecer 18/2005, aprovado dois meses depois, apresentava clara crítica à esta lei, demonstrando contradições nas posições da Câmara de Educação Básica (CEB) no que se refere a Lei 11.114/2005.

Finalmente, em 6 de fevereiro de 2006, a medida de ampliação do ensino fundamental para nove anos, com matrícula aos seis anos de idade, ganha respaldo legal pela Lei $\mathrm{n}^{\circ} 11.274$ (BRASIL, 2006a). Esta Lei alterava a redação dos Art. 29, 30, 32 e 87 da LDB, e previa que a implementação do ensino fundamental de nove anos nos municípios, estados e o Distrito Federal deveria ocorrer até 2010. Com o veto dos Art. $1^{\circ}$ e Art. $2^{\circ}$ (ANEXO 3) da referida lei, 
foram alterados apenas aos Art. 32 e 87 da LDB. O Quadro 5 apresenta os artigos da LDB em sua redação original e as novas redações dadas pela Lei 11.114/2005 e pela Lei 11.274/2006.

Quadro 5. Texto original da LDB e as novas redações dadas pelas Leis 11.114/2005 e $11.274 / 2006$

\begin{tabular}{|c|c|c|}
\hline LDBEN. 9.394/96 & LEI 11.114/05 & LEI 11.274/06 \\
\hline $\begin{array}{l}\text { Art. } 6^{\circ} \text { - É dever dos pais ou responsáveis } \\
\text { efetuar a matrícula dos menores, a partir } \\
\text { dos sete anos de idade, no ensino } \\
\text { fundamental. }\end{array}$ & $\begin{array}{l}\text { Art. } 6^{\circ} \text { - É dever dos pais ou responsáveis } \\
\text { efetuar a matrícula dos menores, a partir } \\
\text { dos seis anos de idade, no ensino } \\
\text { fundamental. (NR) }\end{array}$ & Art. $6^{\circ}-\ldots \ldots \ldots \ldots \ldots \ldots \ldots \ldots \ldots \ldots . . .($ mantido) \\
\hline $\begin{array}{l}\text { Art. } 30-A \text { educação infantil será } \\
\text { oferecida em: } \\
\text { I - creches ou entidades equivalentes, } \\
\text { para crianças de até três anos de idade. }\end{array}$ & $\mid \begin{array}{l}\text { Art. } 30 \\
\text { I }-\ldots \ldots \ldots \ldots \ldots \ldots \ldots \ldots \ldots \ldots \ldots \ldots \ldots \ldots \ldots . . . . .(m a n t i d o)\end{array}$ & 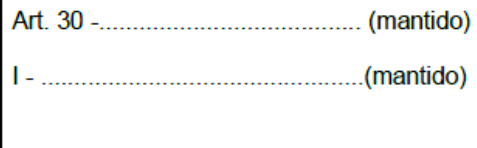 \\
\hline $\begin{array}{l}\text { II - pré-escolas, para crianças de quatro a } \\
\text { seis anos de idade. * }\end{array}$ & $\begin{array}{l}\text { Vetado o inciso II por } \\
\text { inconstitucionalidade. }\end{array}$ & Vetado o inciso II \\
\hline $\begin{array}{l}\text { Art. } 32 \text { - O ensino fundamental, com } \\
\text { duração mínima de oito anos, obrigatório } \\
\text { e gratuito na escola pública, terá por } \\
\text { objetivo a formação básica do cidadão } \\
\text { mediante: }\end{array}$ & $\begin{array}{l}\text { Art. } 32 \text { - O ensino fundamental, com } \\
\text { duração mínima de oito anos, obrigatório } \\
\text { e gratuito na escola pública, a partir dos } \\
\text { seis anos, terá por objetivo a formação } \\
\text { básica do cidadão mediante: }\end{array}$ & $\begin{array}{l}\text { Art. } 32-\text { O ensino fundamental } \\
\text { obrigatório, com duração de } 9 \text { (nove) } \\
\text { anos, gratuito na escola pública, } \\
\text { iniciando-se aos } 6 \text { (seis) anos de idade, } \\
\text { terá por objetivo a formação básica do } \\
\text { cidadão, mediante: }\end{array}$ \\
\hline $\begin{array}{l}\text { Art. } 87 \text { - } \\
\S 2^{\circ} \text { - O Poder Público deverá recensear } \\
\text { os educandos no ensino fundamental, } \\
\text { com especial atenção para os grupos de } \\
\text { sete a quatorze e de quinze a dezesseis } \\
\text { anos de idade. }\end{array}$ & Art. 87 - & $\begin{array}{l}\text { Art. } 87 \text { - } \\
\S 2^{\circ} \text { - O Poder Público deverá recensear } \\
\text { os educandos no ensino fundamental, com } \\
\text { especial atenção para os grupos de seis a } \\
\text { quatorze e de quinze a dezesseis anos de } \\
\text { idade. }\end{array}$ \\
\hline \multirow[t]{2}{*}{$\begin{array}{l}\text { } 3^{\circ}-\text { matricular todos os educandos a partir } \\
\text { de sete anos de idade e, facultativamente, } \\
\text { a partir dos seis anos, no ensino } \\
\text { fundamental. }\end{array}$} & $\begin{array}{l}\S 3^{\circ} \text { - .... } \\
\text { I - matricular todos os educandos a partir } \\
\text { dos } 6 \text { (seis) anos de idade no ensino } \\
\text { fundamental, atendidas as seguintes } \\
\text { condições no âmbito de cada sistema de } \\
\text { ensino: } \\
\text { a) plena observância das condições de } \\
\text { oferta fixadas por esta Lei, no caso de } \\
\text { todas as redes escolares; } \\
\text { b) atingimento de taxa liquida de } \\
\text { escolarização de pelo menos } 95 \% \\
\text { (noventa e cinco por cento) da faixa etária } \\
\text { de } 07 \text { (sete) a } 14 \text { (quatorze) anos, no caso } \\
\text { das redes escolares públicas; e } \\
\text { c) não redução média de recursos por } \\
\text { aluno do ensino fundamental na } \\
\text { respectiva rede pública, resultante da } \\
\text { incorporação dos alunos de } 06 \text { (seis) anos } \\
\text { de idade; }\end{array}$ & $\begin{array}{l}\$ 3^{\circ} \\
\text { de matricular todos os educandos a partir } \\
\text { fundamental. } \\
\text { a) (REVOGADO) } \\
\text { b) (REVOGADO) } \\
\text { c) (REVOGADO) }\end{array}$ \\
\hline & & $\begin{array}{l}\text { Art. } 5^{\circ} \text { - Os Municípios, os Estados e o } \\
\text { Distrito Federal terão prazo até } 2010 \text { para } \\
\text { implementar a obrigatoriedade para o } \\
\text { ensino fundamental disposto no art. } 3^{\circ} \\
\text { desta lei e a abrangência da pré-escola de } \\
\text { que trata o art. } 2^{\circ} \text { desta Lei. }\end{array}$ \\
\hline
\end{tabular}

Fonte: Ministério da Educação/Secretaria de Educação Básica (BRASIL, 2009c), p. 6-7.

Observa-se no Quadro 5 que a principal alteração da Lei 11.274/2006 encontra-se no Art. 32, que determina a ampliação do ensino fundamental para nove anos. Verifica-se, também, que tanto na Lei 11.114/2005 quanto na Lei 11.274/2006 houve o veto da correção 
do texto da LDB sobre a faixa etária atendida pela pré-escola, permanecendo o seu atendimento para a faixa etária de 4 a 6 anos. Analisando-se as mensagens de veto das Leis 11.114 e 11.274, verifica-se que a alterações previstas pelas leis para o Art. 30 da LDB foram vetadas por não estar de acordo com o Art. 208 da Constituição e por não prever a alteração do Art. $4^{\circ}$ da LDB, como se observa na citação abaixo da Mensagem de Veto da Lei 11.274:

De acordo com o art. 208, incisos I e IV, da Constituição, o dever do Estado
com a educação será efetivado mediante a garantia de ensino fundamental
obrigatório e gratuito, assegurada, inclusive, sua oferta gratuita para todos os
que a ele não tiverem acesso na idade própria e atendimento em creche e
pré-escola às crianças de zero a seis anos de idade. A previsão constitucional
de atendimento em creches e pré-escolas está reproduzida no art. $4^{\circ}$ inciso
IV, da Lei no 9.394 , de 1996 , que não foi alterado no presente projeto de lei.
Em assim sendo, e tendo em vista que a educação infantil abrange as creches
e pré-escolas, não há como aceitar as alteraçães sugeridas aos arts. 29 e 30
da Lei $\mathrm{n}^{\mathrm{o}}$ 9.394, de 1996 , constantes do art. $1^{\circ}$ e $2^{-}$do projeto de lei, que
destoam do dispositivo constitucional acima mencionado. Não há que se
falar sequer em adequação à lei em vigor, porque o art. $4^{\circ}$ desta, acima
referido, continuará com redação idêntica à constitucional (BRASIL, 2006a).

Assim, criou-se uma contradição na legislação, que determinava nove anos de duração do ensino fundamental com ingresso aos seis anos, mas definia o atendimento da educação infantil para crianças de zero a seis anos de idade. Em dezembro de 2006 foi aprovada a Emenda Constitucional n $\mathrm{n}^{\mathrm{o}} 53$ (BRASIL, 2006c), que alterou o Art. 208 de forma a prever o atendimento da educação infantil às crianças até cinco anos. No entanto, o Art. $4^{\circ}$ e Art. 30 da LDB permaneciam inalterados. Esta contradição foi corrigida apenas recentemente, com a Lei $\mathrm{n}^{\mathrm{o}} 12.796$ de 4 de abril de 2013 (BRASIL, 2013), que entre outras disposições, altera o Art. $4^{\circ}$ e Art. 30 da LDB determinando o atendimento da educação infantil às crianças até cinco anos de idade, e da pré-escola às crianças de 4 a 5 anos.

O Projeto de Lei no 3.675 (BRASIL, 2004d), de 2004, de autoria da Deputada Professora Raquel Teixeira, foi o projeto que deu origem à Lei 11.274/2006. É interessante notar que o projeto original incluía a alteração do Art $2^{\circ}$ da $\operatorname{LDB}$, que dispõe sobre atendimento da educação infantil, alterando a faixa etária para crianças de zero a cinco anos de idade. Incluía também alteração do Art. 29, de forma a também corrigir o atendimento da educação infantil para crianças de até cinco anos. Fazia também a alteração do Art. 30 que fora vetado na aprovação da Lei 11.274. As alterações no Art. 32 e 87 da LDB também constavam no projeto e foram as únicas alterações determinadas pela Lei 11.274. Assim, observa-se que a lei aprovada não previa as alterações dos Art. $2^{\circ}$ e Art. 29, que constavam no projeto original, e que foram corrigidas apenas em 2013 com a aprovação da Lei $\mathrm{n}^{\circ} 12.796$. 
A Lei 11.274 teve aparentemente maior repercussão entre os estados, municípios e sistemas de ensino, pois após sua promulgação o Conselho Nacional de Educação (CNE) recebeu inúmeros questionamentos advindos de diversas regiões do País, que resultaram na emissão de um número considerável de pareceres desses órgãos (GORNI, MAIESKI e MACHADO, 2012).

Em 2006 foram emitidos três pareceres pelo CNE/CEB - Parecer n 39/2006, Parecer $n^{\circ} 41 / 2006$ e Parecer no 45/2006 - que tratavam de dúvidas sobre a matrícula de crianças de seis anos no Ensino Fundamental, sobre a interpretação da Lei Federal no 11.274, e sobre a forma de trabalhar nas séries iniciais do Ensino Fundamental (GORNI, MAIESKI e MACHADO, 2012; ABBIATI e OLIVEIRA, 2013). No ano seguinte, mais quatro pareceres referiram-se à Lei 11.274/2006 - Parecer no 5/2007 e seu reexame pelo Parecer 7/2007, Parecer $n^{\circ}$ 21/2007 e Parecer no 22/2007 (ABBIATI e OLIVEIRA, 2013).

Abbiati e Oliveira (2013) analisaram todos os pareceres e resoluções emitidos pelo CNE/CEB sobre o ensino fundamental de nove anos, e afirmam que o estabelecimento de normas nacionais para a ampliação, o currículo e a idade de matrícula no ensino fundamental foram alguns dos assuntos mais abordados nestes documentos. A questão da idade de matrícula será discutida a seguir, enquanto as orientações do CNE/CEB contidas nos pareceres sobre a ampliação do ensino fundamental de nove anos e o currículo serão abordadas no tópico seguinte, juntamente com os documentos publicados pelo MEC.

A questão da idade de matrícula foi alvo de muitos questionamentos enviados ao CNE/CEB. No Parecer 7/2007, o relator Murílio de Avellar Hingel afirma:

Com efeito, têm chegado à Câmara de Educação Básica muitas questões sobre o corte de idade, matéria já superada e esclarecida em outros Pareceres e Resolução da Câmara de Educação Básica. De fato não deve restar dúvida sobre a idade cronológica para o ingresso no Ensino Fundamental com a duração de nove anos: a criança necessita ter seis anos completos ou a completar até o início do ano letivo. Pode-se admitir outra interpretação diante de um texto tão claro? Será que alguém pode alimentar alguma dúvida sobre o que significam seis anos completos ou a completar até o início do ano letivo? Será que a tolerância até o início do ano letivo pode ter dupla interpretação? (BRASIL, 2007b, p. 5).

Para Oliveira (s/d), apesar de diversos pareceres do CNE/CEB estabelecerem que a criança deveria ter seis anos completos no início do ano letivo para o ingresso no $1^{\circ}$ ano, "o fator "no início do ano letivo" não foi claro o suficiente para regular a questão e esta acabou tendo interpretação polissêmica nos diversos sistemas educacionais brasileiros” (p. 2). Assim, 
cada estado/município estabeleceu regras diferentes para a questão do corte etário, ficando a criança sujeita a estas alterações (OLIVEIRA, s/d). Segundo a autora, em alguns casos, uma mesma cidade tinha datas-limite diferenciadas para matrícula, como, por exemplo, a cidade de Belo Horizonte, que, na rede estadual, era 30 de junho e, na rede municipal, 30 de abril.

O Parecer n 22 de 2009 (BRASIL, 2009e) e a Resolução n ${ }^{\circ} 1$ de 2010 (BRASIL, 2010a) fixavam as Diretrizes Operacionais para implantação do ensino fundamental de nove anos, estabelecendo as normas que deveriam ser seguidas pelos sistemas de ensino no processo de implantação. O Parecer n ${ }^{\circ}$ 22/2009 buscou esclarecer sobre a questão do corte etário, explicitando a interpretação dada pelo CNE/CEB ao se referir ao "início do ano letivo":

\begin{abstract}
A data de ingresso das crianças no Ensino Fundamental é a partir dos 6 (seis) anos de idade, completos ou a completar até o início do ano letivo, conforme as orientações legais e normas estabelecidas pelo CNE na Resolução CNE/CEB no 3/2005 e nos seguintes Pareceres: CNE/CEB n's 6/2005; 18/2005; 7/2007; e 4/2008. Compreenda-se "início do ano letivo" como o primeiro dia de aula do ano, previsto no calendário escolar do respectivo sistema de ensino (BRASIL, 2009e, p. 4, grifo nosso).
\end{abstract}

Para resolver a questão do desalinhamento entre os entes federados, em janeiro de 2010 foi aprovada a Resolução CNE/CEB n 1, que definiu a data de 31 de março como a data-limite para a criança completar seis anos e ser matriculada no $1^{\circ}$ ano. Segundo Oliveira (s/d), apesar de ter sido definida a data de corte, "foram inúmeras as demandas jurídicas para matrícula de crianças que completam 6 anos após o dia 31 de março" (p. 1). Conforme afirma a autora, algumas unidades federativas como Distrito Federal e Minas Gerais suspenderam a resolução até que o mérito da ação fosse julgado (OLIVEIRA, s/d).

Por fim, em julho de 2010 foi homologado o Parecer CNE/CEB nº 11/2010 (BRASIL, 2010b), que apresentava as Diretrizes Curriculares Nacionais para o Ensino Fundamental de Nove Anos. Este parecer fundamentou a Resolução $n^{\circ}$ 7, de 14 de dezembro de 2010 (BRASIL, 2010c), que fixou as diretrizes curriculares como norma para implementação desta política. Este documento reúne princípios, fundamentos e procedimentos definidos pelo Conselho Nacional de Educação, para orientar a elaboração, implementação e avaliação das propostas curriculares dos Estados, do Distrito Federal, dos Municípios, e dos projetos político-pedagógicos das escolas. Para Abbiati e Oliveira (2013), estas orientações foram publicadas tardiamente, considerando a época em que foram expedidas. Segundo os autores, “a não manifestação do CNE, em tempo oportuno, parece representar que a preocupação maior se 
deu com o aspecto quantitativo, ou seja, mais com o aumento do número de matrículas no Ensino Fundamental, do que com a qualidade do ensino ofertado" (p. 104).

Assim, nesta jornada pela legislação e normatização da política do ensino fundamental de nove anos tecida no presente tópico, observa-se que apenas ao final da jornada foram estabelecidas as normas para sua implantação e publicadas as Diretrizes Curriculares para o ensino fundamental de nove anos. Nesse sentido, fica o questionamento: porque primeiro aprovar a lei para depois publicar os princípios que a fundamentam? Não teria sido mais fácil primeiramente preparar-se adequadamente para depois colocar a medida em prática? De fato, em concordância com a afirmação de Abbiati e Oliveira (2013), parece que a prioridade tratava-se de inserir as crianças de seis anos no ensino obrigatório, a fim de aumentar as matrículas e, com isso, os índices de crianças na escola. Apenas após os muitos questionamentos, advindos de diversas áreas do país é que se observaram medidas que visavam estabelecer normas e diretrizes para o ensino fundamental de nove anos.

As orientações contidas na Resolução n ${ }^{0}$ 7/2010 que fixou as Diretrizes Curriculares do ensino fundamental de nove anos serão abordadas no tópico a seguir, de forma a contextualizá-las junto a outras publicações do Ministério da Educação que apresentam orientações acerca da política do ensino fundamental de nove anos.

\subsection{Orientações do Ministério da Educação para a política do ensino fundamental de nove anos}

Discutidos os acontecimentos históricos e as legislações e normas que estão relacionados à política do ensino fundamental de nove anos, será realizada, neste tópico, uma discussão mais aprofundada sobre a política, apresentando os objetivos do Ministério da Educação com a medida e as orientações para sua implantação, assim como os posicionamentos de estudiosos e pesquisadores da área. Para melhor organizar a discussão, em um primeiro momento serão apresentados os documentos publicados pelo Ministério da Educação para orientar na implementação do ensino fundamental de nove anos. Em um segundo momento, serão apresentados e discutidos com a literatura da área os objetivos da medida expressos nos documentos. Por fim, serão debatidas as orientações do Ministério da Educação acerca das medidas necessárias na implementação do ensino fundamental de nove anos. 


\subsubsection{Sobre os documentos publicados pelo Ministério da Educação}

Entre os principais documentos emitidos pela Secretaria de Educação Básica/Ministério da Educação que contemplam orientações para a implantação do ensino fundamental de nove anos, citam-se as seguintes publicações:

- "Ensino Fundamental de Nove Anos: orientações gerais" (BRASIL, 2004a);

- "Ensino Fundamental de Nove Anos: orientações para a inclusão da criança de seis anos de idade" (BRASIL, 2007c);

- "Ensino Fundamental de Nove Anos: passo a passo do processo de implantação" (BRASIL, 2009c);

- "Ensino Fundamental de Nove Anos: perguntas mais frequentes e respostas da Secretaria de Educação Básica” (BRASIL, 2007d);

- “Acervos complementares: as áreas do conhecimento nos dois primeiros anos do Ensino Fundamental" (BRASIL, 2009a);

- "A criança de 6 anos, a linguagem escrita e o ensino fundamental de nove anos: orientações para o trabalho com a linguagem escrita em turmas de crianças de seis anos de idade" (BRASIL, 2009b).

No presente trabalho, serão apresentadas e discutidas as principais questões abordadas por estes documentos, dando-se uma maior atenção aos três primeiros documentos listados acima, por tratarem mais especificamente de orientações para implementação da proposta do ensino fundamental de nove anos. A seguir serão apresentados estes três documentos, buscando contextualizar o leitor quanto às suas principais características e conteúdos abordados.

Como afirmado no tópico anterior, o documento "Ensino Fundamental de Nove Anos: orientações gerais" (BRASIL, 2004a) foi a primeira publicação elaborada pelo Ministério da Educação com o intuito de prover orientações sobre a política do ensino fundamental de nove anos, baseando-se nas experiências de sistemas que já adotavam o ensino fundamental ampliado. O documento apresentava a fundamentação legal pertinente e discutia temas como organização do tempo e do espaço escolar, trabalho coletivo, formação do professor para atuar com criança de seis anos, tornando-se um referencial para as questões pedagógicas e administrativas para a ampliação do ensino fundamental. 
Após a aprovação da Lei 11.274, ainda em 2006, foi publicado o documento "Ensino Fundamental de Nove Anos: orientações para a inclusão da criança de seis anos de idade" (BRASIL, 2007c), com uma segunda edição no ano seguinte. Este documento, distribuído para as escolas, foi de grande importância por objetivar fornecer subsídios para os professores que atuavam com a criança de seis anos no ensino fundamental. Para Furtado (2009) e Lima (2011), este documento não tem a intenção de definir os conteúdos e diretrizes para o primeiro ano do ensino fundamental, mas incitar a reflexão e orientar as ações das escolas.

Composto de vários artigos de autoria de diferentes estudiosos da área, como Sônia Kramer, Ângela Meyer Borba, Cecília Goulart, Patrícia Corsino, entre outros, este documento tem como foco o desenvolvimento e a aprendizagem das crianças de seis anos, discutindo questões como a alfabetização no $1^{\circ}$ ano, os conteúdos a serem ministrados, a importância do lúdico no cotidiano escolar, entre outros.

Visando orientar o professor no trabalho destes conteúdos em sala de aula, consta de uma série de artigos que trazem orientações pedagógicas e apontam possibilidades de trabalho para essa nova etapa e a reestruturação do ensino fundamental. Nestes artigos são apresentadas também sugestões de projetos a serem desenvolvidos para trabalhar conteúdos, e sugeridas diversas atividades que podem ser desenvolvidas junto aos alunos do $1^{\mathrm{o}}$ ano do ensino fundamental de nove anos, como canto, leitura de fábulas, pesquisas na internet, brincadeiras, entre muitas outras (BRASIL, 2007c). Neste mesmo documento é apresentado um modelo de estrutura curricular para os anos iniciais do ensino fundamental e de organização do trabalho pedagógico, que visa orientar as escolas no processo de implantação da política de ampliação do ensino fundamental.

O próximo documento do Ministério da Educação elaborado para subsidiar a implantação do ensino fundamental de nove anos foi publicado em 2009, denominado "Ensino Fundamental de nove anos: Passo a Passo do Processo de Implantação" (BRASIL, 2009c). Este documento tinha por objetivo "subsidiar gestores municipais e estaduais, conselhos de educação, comunidade escolar e demais órgãos e instituições" (BRASIL, 2009c, p. 5). Além de apresentar orientações para a ampliação do ensino fundamental e todo o seu amparo legal, tratava, pela primeira vez, da reorganização do currículo, da organização pedagógica, e especialmente, da avaliação. Ao final, o documento apresentava as perguntas mais frequentes sobre a ampliação do ensino fundamental seguidas pelas respostas dadas pela SEB/MEC. 
Esta publicação apresentava, também, a sistematização de um Plano de Implementação do novo ensino fundamental a ser desenvolvido por cada sistema de ensino e regulamentado pelas Secretarias e Conselhos de Educação. O documento apontava que, neste Plano, seria imprescindível conter, entre outros:

- redimensionamento do espaço físico;

- reorganização do quadro de professores, quando necessário;

- formação inicial e continuada de professores e demais profissionais da educação;

- adequação e aquisição de mobiliário e equipamentos;

- adequação e aquisição de material didático-pedagógico (BRASIL, 2009c, p. 11).

Assim, é possível observar neste documento a menção a algumas mudanças como imprescindíveis, passando a se referir a elas como condicionantes para a implementação da política do ensino fundamental de nove anos, e não mais como medidas a serem repensadas pelas escolas e sistemas de ensino. Essa alteração ao se referir às mudanças parece indicar uma preocupação do Ministério da Educação em incitar as escolas e sistemas de ensino a realizarem as mudanças listadas no Plano de Implementação.

Paulo Alves da Silva (2012), que de 2005 a 2010 trabalhou no Ministério da Educação compondo a equipe de concepção e implementação da política do ensino fundamental de nove anos, afirma em sua dissertação de mestrado que este documento foi elaborado com vistas a "racionalizar um pouco mais o processo" de implementação desta política (p. 41). As perguntas e respostas ao final do documento de caráter orientador foram baseadas nas correspondências eletrônicas recebidas por profissionais do Ministério da Educação (SILVA, 2012). Para Silva (2012), este documento, de caráter orientador, foi uma ferramenta importante para sanar algumas dúvidas básicas, mas "ainda assim não foi suficiente para que os sistemas de ensino e as escolas discutissem mais amiúde os elementos organizadores do novo ensino fundamental, considerados importantes pela instância responsável pela concepção do projeto" (SILVA, 2012, p. 41).

2.4.2 Sobre os objetivos da política do ensino fundamental de nove anos expressos nos documentos

Analisando-se estes e os demais documentos publicados pelo Ministério da Educação, juntamente com as leis e normas que dissertam sobre esta política, é possível identificar os 
objetivos e intenções declarados pelo MEC com a ampliação do ensino fundamental com ingresso aos seis anos. Conforme pode ser visto no documento "Ensino Fundamental de nove anos: Passo a Passo do Processo de Implantação" (BRASIL, 2009c), constavam como objetivos dessa política:

a) Melhorar as condições de equidade e de qualidade da Educação Básica;

b) Estruturar um novo ensino fundamental para que as crianças prossigam nos estudos, alcançando maior nível de escolaridade;

c) Assegurar que, ingressando mais cedo no sistema de ensino, as crianças tenham um tempo mais longo para as aprendizagens da alfabetização e do letramento (BRASIL, 2009b, p. 5).

O Ministério da Educação afirma nos documentos que, com a implementação desta política, previa-se a inclusão de um número maior de crianças no sistema educacional brasileiro, o que contribuiria para equiparar as oportunidades educacionais entre as camadas mais populares da sociedade brasileira e as mais favorecidas (BRASIL, 2004a). Segundo o órgão público, "os setores populares deverão ser os mais beneficiados, uma vez que as crianças de seis anos da classe média e alta já se encontram majoritariamente incorporadas ao sistema de ensino - na pré-escola ou na primeira série do ensino fundamental" (BRASIL, 2004a, p. 17).

A partir disso, acreditava-se que a política do ensino fundamental de nove anos asseguraria o direito às crianças de seis anos à educação. Na legislação e nos documentos orientadores, é possível encontrar diversos textos que reforçam esta argumentação. No documento "Ensino Fundamental de Nove Anos: orientações para a inclusão da criança de seis anos de idade" (BRASIL, 2007c), Anelise Monteiro do Nascimento afirma:

[...] podemos ver o ensino fundamental de nove anos como mais uma estratégia de democratização e acesso à escola. A Lei $\mathrm{n}^{\circ}$. 11.274, de 6 de fevereiro de 2006, assegura o direito das crianças de seis anos à educação formal, obrigando as famílias a matriculá-las e o Estado a oferecer o atendimento. (Brasil, 2007, p. 27)

Em outro capítulo do mesmo documento, Patricia Corsino corrobora essa ideia ao apresentar o ensino fundamental de nove anos como uma oportunidade histórica para as crianças de seis anos de classes populares frequentarem a escola:

[...] a ampliação do ensino fundamental para nove anos, que significa bem mais que a garantia de mais um ano de escolaridade obrigatória, é uma oportunidade histórica de a criança de seis anos pertencente às classes 
populares ser introduzida a conhecimentos que foram fruto de um processo sócio-histórico de construção coletiva. (Brasil, 2007, p. 61-62)

$\mathrm{Na}$ discussão sobre o ensino fundamental de nove anos, é possível observar entre os estudiosos da área argumentos que defendem, bem como outros que questionam a medida. Entre os argumentos favoráveis à medida, a universalização do ensino para as crianças de seis anos é o mais defendido pelos estudiosos. Para Flach (2009), esta política representa um "grande avanço na realidade educacional brasileira", por garantir o direito à educação às crianças de seis anos (FLACH, 2009, p. 515). Para Saveli (2008), “o acesso à educação obrigatória mais cedo se constitui em um instrumento de luta política, para que todas as crianças, inclusive as das classes populares, possam usufruir da igualdade de oportunidades" (SAVELI, 2008, p. 68). Neste sentido, Kramer (2006) também defende que incluir as crianças de seis anos no ensino fundamental representa uma oportunidade de superar as desigualdades de acesso à educação.

Já para Craidy e Barbosa (2012), o fato das crianças mais favorecidas já se encontrarem na escola traz a "ilusão de que obrigar todas as crianças a ingressarem aos 6 anos na $1^{\text {a }}$ série seria uma forma de construir uma situação igualitária e democratizar o ensino” (p. 24). As autoras criticam a entrada compulsória de crianças de maior vulnerabilidade pessoal e social em uma escola que lhes é estranha, por viverem em ambiente pouco letrado e desconhecerem a cultura escolar, uma vez que não frequentaram a educação infantil (CRAIDY e BARBOSA, 2012). Nesse sentido, afirmam que "democratizam-se oportunidades tratando os desiguais como iguais. [...] Democratizar o acesso sem garantir a aprendizagem escolar é uma forma de tratar igualmente sujeitos com histórias desiguais" (CRAIDY e BARBOSA, 2012, p. 25; 26).

Para Arelaro, Jacomini e Klein (2011), o argumento de que a política do ensino fundamental de nove anos garantiria um maior número de crianças matriculadas nas escolas e, portanto, asseguraria a elas o direito à educação, parte de pressupostos que não condizem com a legislação brasileira. As autoras argumentam que o direito das crianças à educação já era assegurado pelo Art. 208 da Constituição Federal, e portanto, "nos termos da lei, o direito das crianças à educação formal, desde seu nascimento, está garantido" (ARELARO, JACOMINI e KLEIN, 2011, p. 39). As autoras pontuam, ainda, que muitas das crianças de seis anos estavam fora da escola por não existir oferta de vagas suficientes na educação infantil. Nesse sentido, afirmam que 
Se o governo reconhece que as instituições de educação infantil não ofertam vagas suficientes para atender a estas crianças, a consequência lógica seria o estímulo técnico-financeiro para que os municípios assumissem sua responsabilidade constitucional. No entanto, a opção foi por uma política nacional de novo lócus de estudo dessa criança, uma transferência de etapa de ensino que significou uma mudança radical de diversos aspectos no atendimento (ARELARO, JACOMINI e KLEIN, 2011, p. 39).

As autoras apontam, ainda, que a política do ensino fundamental de nove anos não garantiu um maior número de alunos matriculados na escola. Por meio de análise das taxas de matrículas no ensino fundamental no período de 2004 a 2009, as autoras observaram uma redução no número total de atendimento de alunos no ensino fundamental. A Tabela 3 mostra as taxas de matrículas no ensino fundamental de oito e de nove anos no período analisado pelas autoras:

Tabela 3: Número de matrículas no ensino fundamental de oito e nove anos

\begin{tabular}{c|c|c|c|c|c}
\hline \multicolumn{2}{c}{} & \multicolumn{3}{c}{ Matrículas no Ensino Fundamental } \\
\hline Brasil & Total & Rede pública & Rede privada & Rede pública & Rede privada \\
\hline 2004 & 34.012 .434 & 23.384 .918 & 3.229 .388 & 7.296 .036 & 102.092 \\
\hline 2005 & 33.534 .561 & 22.854 .792 & 3.245 .270 & 7.982 .320 & 131.499 \\
\hline 2006 & 33.282 .663 & 19.763 .812 & 2.853 .236 & 10.050 .874 & 614.741 \\
\hline 2007 & 32.122 .273 & 16.367 .891 & 1.534 .138 & 12.560 .714 & 1.659 .530 \\
\hline 2008 & 32.086 .700 & 14.208 .026 & 1.246 .645 & 14.260 .670 & 2.371 .359 \\
\hline 2009 & 31.705 .528 & 12.008 .613 & 986.359 & 15.918 .526 & 2.792 .030 \\
\hline
\end{tabular}

Fonte: Arelaro, Jacomini e Klein (2011), p. 41.

Como se pode observar na Tabela 3, a redução no número de matrículas no ensino fundamental foi de mais de dois milhões, quando se observa o número total de matrículas de 2004 a 2009 . Este dado permite afirmar que, apesar de incorporar um ano de pré-escola, o número de alunos matriculados não aumentou com o ensino fundamental de nove anos (ARELARO, JACOMINI e KLEIN, 2011).

Esta queda no número de matrículas no ensino fundamental também é relatada por Correa (2010), após analisar dados do Censo Escolar de 2009. Além disso, a autora verificou nos dados do Censo uma redução também nas matrículas na pré-escola: em 2008, foram registradas 4.967.525 matrículas nesta modalidade de ensino, já em 2009, houveram 4.866.268 matrículas, havendo, portanto, queda de $2 \%$ de um ano para outro. Este dado 
permite afirmar que as vagas que antes eram ocupadas pelas crianças de seis anos na educação infantil não foram preenchidas pelas crianças de cinco anos que se encontravam fora da escola. Ademais, as matrículas no ensino fundamental também apresentaram queda, mesmo com a inclusão das crianças de seis anos. Nesse contexto, fica a dúvida: para onde foram as crianças de seis anos?

Apesar dos dados referentes as matrículas por si só não permitirem conclusões, é interessante notar essas alterações, especialmente para evidenciar que a expectativa de aumento das matrículas com a ampliação do ensino obrigatório e garantia do direito à educação às crianças não se alcançam sem medidas mais direcionadas para este fim. Para se ter uma visão clara do cenário seria necessária uma análise demográfica, o que os dados do censo escolar não permitem fazer. No entanto, levando-se em conta as considerações feitas até o momento, pode-se afirmar que ainda é controverso se a política do ensino fundamental de nove anos poderia cumprir com seu objetivo de melhorar as condições de equidade ao acesso à educação.

Outro objetivo da proposta tratava-se de assegurar à criança um tempo mais longo para as aprendizagens da alfabetização e do letramento, ao ingressar aos seis anos no ensino fundamental. Conforme pode ser observado nos documentos, segundo o Ministério da Educação, acreditava-se que o ingresso da criança aos seis anos na escola poderia oportunizar um salto na qualidade da educação ao aumentar o tempo de permanência na escola e o sucesso no aprendizado. Segundo o órgão público, estudos realizados pelo Sistema Nacional de Avaliação da Educação Básica (Saeb) mostraram que crianças com histórico de experiência na pré-escola obtiveram melhores médias de proficiência em leitura (BRASIL, 2007c). Para o MEC, este dado indicava que "quando as crianças ingressam na instituição escolar antes dos sete anos de idade, apresentam, em sua maioria, resultados superiores em relação àquelas que ingressam somente aos sete anos” (BRASIL, 2007c, p. 5).

Neste quesito também é possível observar entre os estudiosos argumentos que defendem e que questionam esta argumentação do MEC. Santos e Vieira (2006) apresentam argumentos favoráveis, afirmando que, com um ano de acréscimo, as escolas conseguiriam uma melhor socialização e inserção da criança em um universo cultural novo, criando mais oportunidades de aprendizado. Desse modo, segundo as autoras, haveria melhores condições para a alfabetização das crianças, sendo este considerado um dos problemas históricos da educação brasileira. No entanto, a nosso ver, esta argumentação não justifica a inclusão das crianças de seis anos no ensino fundamental. Pelo contrário, seguindo este argumento, a 
melhor estratégia para promover uma melhor socialização e inserção da criança na cultura escolar parece ser tornar obrigatório o último ano da educação infantil.

Conforme afirma Abramowicz (2006), tanto as estatísticas nacionais como as internacionais demonstram que a criança que frequenta a pré-escola tem um desempenho escolar superior àquelas que não frequentam. No entanto, compreender este dado como decorrendo do ingresso antecipado na cultura escolar, sem considerar a estrutura da educação infantil, seus princípios, e as características do ensino oferecido nesta modalidade, é um entendimento simplista que não leva em consideração todos os fatores envolvidos (ABRAMOWICZ, 2006). Assim, como afirma Abramowicz (2006), “é um pouco do entendimento simplista deste fato que agrega razões à escola de 9 anos” (p. 323).

Portanto, estas estatísticas parecem se referir mais às vivências de educação infantil do que à idade de início dos estudos por si só. Segundo Bertini et al. (2008), “o Ensino Fundamental mais longo já é realidade em alguns países europeus e americanos, mas não há na literatura estudos sobre a relação entre a idade com que se começa e o sucesso das crianças no processo de alfabetização e a qualidade do ensino (p. 66). Assim, não há na literatura dados que relacionem diretamente a idade de ingresso no ensino fundamental com o sucesso na aprendizagem.

Neste debate, é de grande relevância o questionamento de Correa (2010):

Considerando a extensão da escolaridade como algo que, em princípio, poderia representar maiores possibilidades de aprendizagem a um contingente significativo de crianças brasileiras, faz-se necessário questionar em que medida esse acréscimo pode, de fato, lograr tal objetivo. Assim, perguntamos: aumentar em um ano a experiência escolar sem alterar as condições objetivas da escola não pode significar apenas acrescentar mais do mesmo? (p. 314).

Portanto, na busca pelo objetivo de assegurar o direito das crianças de seis anos à educação e viabilizar seu acesso à escola, e de assegurar seu sucesso no aprendizado e melhor qualidade de ensino, parece ser uma opção muito mais interessante tornar obrigatório o último ano da educação infantil, em vez de inserir as crianças de seis anos no ensino fundamental.

Como afirmam Abramowicz (2006) e Correa (2010), ao que tudo indicava, a opção por ampliar o ensino fundamental para nove anos e com ingresso aos seus anos de idade visava normatizar algo que já vinha ocorrendo em parte dos sistemas, ou seja, a incorporação das crianças de seis anos no ensino fundamental como meio de se conseguir mais recursos do 
Fundef, como já discutido no presente trabalho. Para Abramowicz (2006), esta intenção é bem clara, e está explicitada nos documentos do MEC. "Portanto, a ampliação de um ano da escolaridade é uma política educacional econômica, pois, por um lado, a ampliação da Educação Infantil oneraria o Estado e, por outro, o Estado já estava pagando, na prática, em alguns municípios, por esta ampliação" (ABRAMOWICZ, 2006, p. 319).

\subsubsection{Sobre as orientações do Ministério da Educação para implementação do ensino} fundamental de nove anos

Segundo o Ministério da Educação, com a política do ensino fundamental de nove anos buscava-se, ainda, contribuir para mudanças na estrutura e na cultura escolar, visando estruturar um novo ensino fundamental. Para se alcançar este objetivo, são mencionadas nos documentos uma série de medidas que deveriam ocorrer no âmbito escolar na implementação dessa política. Conforme é afirmado nos documentos, para o Ministério da Educação a implementação do ensino fundamental de nove anos deveria envolver uma reestruturação do currículo e uma readequação das escolas, para que fossem estruturalmente capazes de receber os novos alunos, e pedagogicamente capazes de educá-los de forma mais democrática, justa e igualitária (BRASIL, 2004a).

Para isso, segundo o Ministério da Educação seria necessário reorganizar toda a escola, as formas de gestão, os ambientes, os espaços, os tempos, os materiais, os conteúdos, as metodologias, os objetivos e o planejamento para que atendam às necessidades e direitos das crianças de seis anos (BRASIL, 2004a). Assim, de forma geral, eram apontadas como medidas imprescindíveis na implementação desta política: (a) readequação do espaço físico, (b) formação de professores; (c) elaboração de novo currículo e proposta pedagógica; e (d) maior inserção do lúdico no cotidiano escolar (BRASIL, 2009c). Estas medidas serão analisadas a seguir, apresentando-se as orientações do Ministério da Educação a respeito de cada uma e, num segundo momento, discutindo-as com a literatura pertinente.

A respeito das readequações no espaço físico escolar, o Ministério da Educação afirmava nos documentos que, para acolher a criança de seis anos no ambiente escolar deveriam ser providenciadas novas cadeiras e carteiras próprias ao seu tamanho, novas salas de aulas para as turmas ingressantes, espaços destinados a diferentes vivências (interno e externo), entre outros (BRASIL, 2004a; BRASIL, 2007c; BRASIL, 2009a; BRASIL, 2009b; 
BRASIL, 2009c). Assim, observa-se nos documentos que o redimensionamento do espaço físico e a adequação e aquisição de mobiliário e equipamentos são considerados pelo MEC como medidas indispensáveis a serem tomadas pelas escolas e sistemas de ensino, na implementação da política do ensino fundamental de nove anos.

Sobre a formação dos professores, o MEC afirmava nos documentos ser este um elemento fundamental para o sucesso da política de ampliação do ensino fundamental, sendo considerado essencial que o professor esteja sintonizado com os aspectos relativos aos cuidados e à educação das crianças de seis anos, e "esteja receptivo ao conhecimento das diversas dimensões que as constituem no seu aspecto físico, cognitivo-linguístico, emocional, social e afetivo" (BRASIL, 2004a, p. 25).

Afirmava, ainda, que a formação inicial e continuada de professores e demais profissionais da educação era de responsabilidade dos sistemas de ensino, citando o Art. 67 da LDB nesse quesito:

\footnotetext{
Em relação à formação de professores, lembramos o estabelecido no artigo 67 da LDB 9.394/96, os sistemas de ensino promoverão a valorização dos profissionais da educação, assegurando-lhes, inclusive nos termos dos estatutos e dos planos de carreira do magistério público:

I - ingresso exclusivamente por concurso público de provas e títulos;

II - aperfeiçoamento profissional continuado, inclusive com licenciamento periódico remunerado para esse fim;

III - piso salarial profissional;

IV - progressão funcional baseada na titulação ou habilitação, e na avaliação do desempenho;

$V$ - período reservado a estudos, planejamento e avaliação, incluído na carga de trabalho;

VI - condições adequadas de trabalho (BRASIL, 2009c, p. 17-18, grifo no original).
}

Ademais, o Ministério da Educação afirmava que os programas de formação continuada deveriam privilegiar "a especificidade do exercício docente em turmas que atendem a crianças de seis anos" (BRASIL, 2004a, p. 25).

A respeito da elaboração de um novo currículo e proposta pedagógica para as crianças de seis anos, o MEC afirmava que o ingresso destas crianças no ensino fundamental não se tratava de "transferir para as crianças de seis anos os conteúdos e atividades da tradicional primeira série, mas de conceber uma nova estrutura de organização dos conteúdos em um Ensino fundamental de nove anos, considerando o perfil de seus alunos" (BRASIL, 2004a, p. 17). Assim, o Ministério da Educação orientava para a elaboração de um novo currículo e 
proposta pedagógica centrados nas necessidades das crianças de seis anos, trabalhando diversas áreas do conhecimento e inserindo o lúdico no cotidiano escolar destas crianças.

Além disso, o MEC orientava nos documentos que os conteúdos de alfabetização e letramento fossem trabalhados ao longo dos três primeiros anos do ensino fundamental, para que houvesse maior tempo para o aprendizado destes conteúdos. Segundo o Ministério da Educação, no ensino fundamental de oito anos, os professores enfrentavam dificuldades quanto à grande quantidade de conteúdos a serem ministrados na $1^{\mathrm{a}}$ série (BRASIL, 2009b). Conforme afirma o órgão público, em decorrência disso muitos professores "esforçavam-se para alfabetizar o aluno no primeiro semestre da primeira série. A partir daí, procurava-se adentrar a programação "específica” desse nível de ensino" (BRASIL, 2009b, p. 7). O Ministério da Educação afirma, ainda, que esta situação implicava, muitas vezes, em complicações quanto ao ensino das demais áreas do conhecimento:

Como dificilmente o complexo processo de alfabetização cumpria-se em um único semestre, um dos resultados mais frequentes dessa situação era, de um lado, a extensão do trabalho com a apropriação do sistema alfabético de escrita para, ao menos, todo o primeiro ano; de outro lado, o adiamento para a segunda série da apresentação ao aluno dos primeiros conhecimentos disciplinares (BRASIL, 2009b, p. 7).

Para o MEC, com um ano a mais para serem trabalhados os conteúdos de alfabetização e letramento, assegurava-se maior chance de sucesso escolar. Conforme afirma o órgão público, "uma nova perspectiva se abre, portanto, para um tratamento didático mais consistente e sistemático tanto dos objetos de ensino-aprendizagem próprios desse ciclo, quanto daqueles que estão associados às diferentes disciplinas curriculares" (BRASIL, 2009a, p. 8).

Além disso, para o Ministério da Educação o ensino fundamental de nove anos contribuiria para a estruturação de um novo ensino fundamental, por meio da elaboração de uma nova proposta curricular para os demais anos desta modalidade de ensino. Conforme afirma o órgão público,

Faz-se necessário elaborar uma nova proposta curricular coerente com as especificidades não só da criança de seis anos de idade, como também das demais crianças de sete, oito, nove e dez anos de idade que constituem os cinco anos iniciais do Ensino fundamental, como os anos finais dessa etapa de ensino (BRASIL, 2007c, p. 11). 
É apenas neste quesito que as orientações do MEC abarcam também os demais anos do ensino fundamental, sem se observar, no entanto, medidas voltadas para os outros anos desta etapa de ensino. Observa-se, de forma geral, que as orientações do MEC se referem às crianças de seis anos e sua inclusão no ensino fundamental, podendo-se afirmar que esta política não contribuiu para a formação de uma nova estrutura do ensino fundamental, como se previa nos objetivos da proposta. Apenas ao tratar do currículo foram mencionados os demais anos do ensino fundamental, o que parece ser, no entanto, mais um resultado de um “efeito dominó” pelo acréscimo de um ano nesta etapa de ensino, do que uma intenção real de modificar a estrutura e a cultura do ensino fundamental, de forma a promover maior qualidade do ensino.

De acordo com o Ministério da Educação, "a definição de conteúdos é de competência dos sistemas de ensino" (BRASIL, 2007d, p. 8). Deste modo, o MEC afirmava nos documentos que "organizar o trabalho pedagógico da escola e da sala de aula é tarefa individual e coletiva de professores, coordenadores, orientadores, supervisores, equipes de apoio e diretores" (BRASIL, 2007c, p. 11). Outrossim, orientava que o trabalho pedagógico com as crianças de seis anos deveria assegurar "o estudo das diversas expressões e de todas as áreas do conhecimento" (BRASIL, 2009c, p. 24). Portanto, o Ministério da Educação orientava em seus documentos que os conteúdos a serem trabalhados junto ao $1^{\circ}$ ano do ensino fundamental de nove anos deveriam envolver não apenas alfabetização e letramento, mas também as diversas áreas de conhecimento, como ciências, matemática, história, geografia e artes (CORSINO, 2007; BRASIL, 2009c).

Neste contexto de reestruturação curricular, o Ministério da Educação fazia também algumas considerações acerca do processo de avaliação. Para o órgão público, a implementação do ensino fundamental de nove anos se constituía também "como uma oportunidade de rever concepções e práticas de avaliação do ensino-aprendizagem, partindo do princípio de que precisamos, na educação brasileira, de uma avaliação inclusiva" (BRASIL, 2007c, p. 11). Nesse sentido, nos documentos o MEC orientava para a realização de processos avaliativos que rompessem com o caráter classificatório e de verificação de saberes:

Ressaltamos a importância de uma escola que, para avaliar, lança mão da observação, do registro e da reflexão constantes do processo de ensinoaprendizagem porque não se limita a resultados finais traduzidos em notas ou conceitos. [...] É nessa perspectiva de avaliação que reafirmamos um movimento que procura romper com o caráter meramente classificatório e de 
verificação dos saberes, que busca constituir nos tempos e espaços da escola e da sala de aula uma prática de avaliação ética e democrática (BRASIL, 2007c, p. 11).

Assim, o MEC orientava as escolas e sistemas de ensino a repensarem "determinadas concepções de avaliação que se traduzem e se perpetuam em práticas discriminatórias e redutoras das possibilidades de aprender" (BRASIL, 2007c, p. 11), considerando estas medidas como urgentes neste processo de ampliação do ensino fundamental. Analisando-se os posicionamentos presentes nos documentos deste órgão público, é interessante notar como que, ao se referir a estas medidas, ora se fala em "oportunidade", o que sinaliza um caráter facultativo, ora se fala em "urgência" dando a entender um caráter imperativo.

Observa-se, com isso, uma contradição entre as orientações do MEC e suas ações quanto à avaliação. As avaliações nacionais como a Provinha Brasil e a ANA (Avaliação Nacional da Alfabetização), cujo objetivo é diagnosticar o nível de alfabetização em Língua Portuguesa e Matemática (apenas na ANA), são aplicadas a todas as crianças do $2^{\circ}$ ano (no caso da Provinha Brasil) e do $3^{\circ}$ ano (no caso da ANA) matriculadas nas escolas públicas brasileiras. Estas avaliações acontecem por meio de testes que avaliam o desempenho do aluno, com a aplicação de uma prova padronizada. Assim, o que são os testes nacionais se não um método classificatório e de verificação de saberes? Dessa forma, observa-se que o MEC orienta as escolas com propostas que o próprio órgão não cumpre, ao manter um sistema de avaliação baseado no ranqueamento a partir do desempenho dos alunos.

Por fim, é possível observar nos documentos do MEC uma preocupação quanto à presença do aspecto lúdico nesta nova estruturação do ensino fundamental. Para o Ministério da Educação, a principal atividade da criança até os seis anos é o brinquedo, e é por meio dele que ela vai se constituindo (BRASIL, 2004a; BRASIL, 2007c). As escolas eram orientadas a garantir o acesso das crianças de seis anos a diversos jogos e brinquedos, considerados como elementos importantes para esta faixa etária. Ainda nesse sentido, o Ministério da Educação orientava os professores, especialmente os que lecionavam para o $1^{\circ}$ ano do ensino fundamental de nove anos, a organizarem sua atuação pedagógica com jogos e brincadeiras, a fim de que resgatem a ludicidade em sala de aula (BRASIL, 2004a; BRASIL, 2007c; BRASIL, 2009a; BRASIL, 2009b; BRASIL, 2009c).

Como afirma Campos (2007), a partir da ampliação do ensino fundamental tornava-se mais urgente rever os referenciais pedagógicos, garantir a formação em serviço dos professores de forma a assegurar uma transição suave para as crianças, propiciar recursos 
materiais e pedagógicos adequados, implantar ciclos de aprendizagem e evitar a repetência precoce. Para a autora, "o desafio, portanto, é garantir que isso aconteça de forma a beneficiar as crianças, principalmente aquelas que não tinham acesso à pré-escola antes dessa mudança" (CAMPOS, 2007, p. 23). Para Costa (2009), o discurso apresentado nos documentos do MEC ameniza a urgência de medidas nas escolas que respeitem as necessidades das crianças de seis anos, ao colocar as adequações da escola para a inclusão da criança de seis anos como necessárias de serem repensadas, em vez de condicionantes para a inclusão das crianças de seis anos (COSTA, 2009).

Para Bertini et al. (2008), os documentos disponibilizados pelo MEC assumem a necessidade da elaboração de novo currículo, mas incumbem a cada sistema de ensino a definição dos conteúdos. Conforme afirmam as autoras, "Cabe a ele [o sistema de ensino], a partir dos textos para orientações oferecidos pelo MEC, estabelecer os conteúdos, fazendo a conexão entre a Educação Infantil e o Ensino Fundamental" (BERTINI ET AL., 2008, p. 72). Para isso, o professor precisa ter conhecimento pedagógico e curricular característicos dessas duas modalidades de ensino, evidenciando a relevância e necessidade da formação continuada dos docentes. Kramer (2006), em particular, ressalta essa necessidade:

Os processos de formação configuram-se como prática social de reflexão contínua e coerente com a prática que se pretende implementar. Cursos esporádicos e emergenciais não resultam em mudanças significativas, nem do ponto de vista pedagógico, nem do ponto de vista da carreira (p. 806).

Pereira e Bonfim (2009) também ressaltam a necessidade da formação continuada, apontando que é preciso que os educadores conheçam a criança de seis anos, para que saibam respeitar suas características psicológicas, motoras, cognitivas e sociais, necessitando, para isto, de uma boa formação voltada a estes propósitos (PEREIRA e BONFIM, 2009).

Para Flach (2009), se na prática escolar a ampliação do ensino fundamental representar apenas uma antecipação da alfabetização, esse fato pode implicar na supressão de um importante trabalho realizado na educação infantil, que focaliza o desenvolvimento da criança enquanto indivíduo e ser social. Nesse sentido, a autora afirma que a reestruturação do currículo é de grande importância, pois incluir as crianças de seis anos no ensino fundamental sem criar mecanismos que atendam às suas necessidades e que possibilitem a permanência e aprendizado destes alunos pode significar um desrespeito à infância (FLACH, 2009).

Segundo Campos (2007), não só é necessária uma revisão de diretrizes, parâmetros e referenciais adequando-os a nova organização do ensino fundamental, mas também 
torna-se urgente o compromisso dos sistemas e das unidades em traduzir essas orientações gerais em projetos pedagógicos ajustados à realidade local, de forma a dar segurança aos professores, aos pais e às próprias crianças, tornando claros, para todos, os objetivos de aprendizagem que estão sendo trabalhados e os critérios de avaliação adotados (CAMPOS, 2007, p. 25).

Nesse sentido, Bertini et al. (2008) e Arelaro, Jacomini e Klein (2011) ressaltam o caráter apenas orientador dos documentos do Ministério da Educação. Bertini et al. (2008) afirmam que,

Tendo em vista a atual realidade, não houve, em âmbito nacional, reflexões e nem ações voltadas para as necessidades da reorganização de estruturas físicas, metodológicas, curriculares e teóricas que a ampliação do Ensino Fundamental necessita. O que notamos nos documentos do Ministério da Educação são apenas orientações dirigidas para a viabilidade ou não da implantação do Ensino Fundamental de nove anos no território nacional (p. 66-67).

Assim, as autoras ressaltam a ausência de ações do Ministério da Educação voltadas para as necessidades apontadas nos documentos, que resumiu-se a orientações aos sistemas de ensino. Para Arelaro, Jacomini e Klein (2011),

Evidentemente que essa iniciativa é importante na preparação das redes de ensino para a realização do ensino fundamental de nove anos. No entanto, é preciso saber em que medida os sistemas de ensino se apropriaram das orientações do MEC, principalmente as apresentadas na publicação Ensino fundamental de nove anos: orientações para a inclusão da criança de seis anos de idade (Brasil, 2007), ou construíram suas próprias, baseadas nessas orientações (2011, p. 43).

Levando-se em conta estas considerações, Arelaro (2005) adverte que o grande número de publicações de documentos orientadores pode ser compreendido como uma estratégia política com vistas a "camuflar" a necessidade de maior discussão sobre as novas medidas necessárias com a implementação da política. Como afirma a autora, a publicação de documentos com orientações

[...] economiza "tempo", já que é mais rápido, pois não precisa discutir com muita gente; economiza recursos financeiros, porque se pode "imprimir" um número maior de manuais e orientações a serem adotados por um maior número de docentes (ainda que de estados com culturas, histórias e curiosidades diferentes) (Arelaro, 2005, p. 1056). 
Para Jacomini e Klein (2010), as preocupações do Ministério da Educação expressas nos documentos se configuram como um alerta, que, no entanto, não impediu a homologação desta política. Contudo, como ressaltam as autoras, são as crianças, os pais, os professores e os gestores escolares que acompanham as mudanças provocadas pela sua implementação e sofrem suas consequências. Nesse sentido, “a concretização dessa política deveria considerar suas opiniões, suas sugestões e angústias, perante as organizações das redes de ensino e possibilidades de mudanças do Ensino Fundamental" (JACOMINI e KLEIN, 2010, p. 85), afinal, são estes que tornarão possíveis as mudanças almejadas com a implementação do ensino fundamental de nove anos.

Bertini et al. (2008) fazem crítica à definição tardia das Diretrizes Curriculares Nacionais para o Ensino Fundamental de Nove Anos, e questionam:

Tais diretrizes não deveriam ter sido elaboradas e discutidas antes da implementação da política? Se assim não foi, não nos parece estranho que os professores e gestores apresentem dúvidas e ansiedades no que diz respeito ao currículo? Afinal, já estão trabalhando num novo sistema de ensino, que ainda não possui uma diretriz pedagógica e curricular. Será que, de alguma forma, isso não poderá influenciar de maneira negativa os resultados? (p. $71)$.

Segundo as autoras, uma discussão prévia dessa temática e elaboração das diretrizes antes da implementação da política poderiam ter diminuído os problemas, as angústias, e dúvidas. Com isso, as autoras defendem que a prévia elaboração das Diretrizes Curriculares tornaria o processo de implementação "um pouco menos complexo e conturbado e auxiliaria muito o trabalho de professores e gestores, assim como a aprendizagem/desenvolvimento dos alunos" (BERTINI ET AL., 2008, p. 71).

Antes de finalizar o capítulo, faz-se relevante, ainda, apresentar algumas considerações sobre a questão da avaliação. Também neste quesito, é possível questionar até que ponto os sistemas de ensino se apropriaram das orientações do Ministério da Educação, colocando-as em prática de acordo com a realidade local. Como afirmado anteriormente, os documentos do MEC afirmavam a necessidade de romper com processos avaliativos de caráter classificatório e de verificação de saberes. Nesse sentido, é defendido nos documentos como um princípio do ensino fundamental de nove anos a "não aplicação de qualquer medida que possa ser interpretada como retrocesso, o que poderia contribuir para o indesejável fracasso escolar" (BRASIL, 2009c, p. 11). 
Para Campos (2007), o trabalho de conteúdos de alfabetização realizado agora nos dois primeiros anos do ensino fundamental significava que "aqueles resultados de aprendizagem que tradicionalmente se esperavam ao final da primeira série, agora podem ser adiados e enriquecidos, aproveitando o período mais longo previsto para a finalização do primeiro segmento do ensino fundamental" (p. 25). Neste sentido, a autora aponta para a necessidade de que os dois primeiros anos ocorram como um ciclo, sem interrupção por meio da repetência do aluno: "a escola de nove anos deve representar para os alunos melhores oportunidades de acesso ao conhecimento e não a antecipação de experiências de fracasso. [...] Nunca é demais frisar que a repetência precoce não pode ser aceita” (p. 25).

Também se encontra referência a esta questão da repetência no Parecer CNE/CEB n ${ }^{\circ}$ 11/2010, que define as Diretrizes Curriculares Nacionais para o Ensino Fundamental de Nove Anos:

\begin{abstract}
Mesmo quando o sistema de ensino ou escolas no uso de sua autonomia fizerem opção pelo regime seriado, será necessário considerar os três anos iniciais do Ensino Fundamental como um bloco pedagógico ou um ciclo sequencial não passível de interrupção, voltado para ampliar a todos os alunos as oportunidades de sistematização e aprofundamento das aprendizagens básicas, imprescindíveis para o prosseguimento dos estudos (BRASIL, 2010b, grifo nosso).
\end{abstract}

No entanto, como mostram Arelaro, Jacomini e Klein (2011), à medida que o ensino fundamental de nove anos foi sendo implementado, em especial a partir do ano de 2006, o número de reprovações das crianças na série inicial aumentou de forma expressiva, chegando a 79300 crianças reprovadas no $1^{\circ}$ ano do ensino fundamental de nove anos em 2009, segundo dados da Folha de São Paulo (ARELARO, JACOMINI e KLEIN, 2011). Conforme afirmam as autoras, este aumento parece seguir uma tendência existente mesmo em anos anteriores.

Portanto, apesar das orientações do MEC para a não reprovação no primeiro ano do ensino fundamental, este índice tem aumentado a cada vez mais, sendo possível questionar se as orientações do MEC estão sendo levadas em consideração na implementação do ensino fundamental de nove anos.

Por fim, nesse contexto encontram-se também as avaliações externas, como a Provinha Brasil, que se constitui uma avaliação de incidência nacional, aplicada aos egressos do primeiro ano do ensino fundamental. Seu objetivo é avaliar o rendimento das escolas públicas do país, e apresenta uma visualização das necessidades dos alunos das séries iniciais em seu desenvolvimento quanto à leitura e escrita. Assim, observa-se uma contradição do 
Ministério da Educação, pois orientava em seus documentos sobre o ensino fundamental de nove anos para a realização de processos avaliativos que rompessem com o caráter classificatório, mas manteve o mecanismo das avaliações externas, que contribuem para a manutenção de processos avaliativos classificatórios e de verificação de saberes e, por serem provas padronizadas, não levam em consideração as particularidades das escolas e seus alunos.

Viu-se até o momento, no presente capítulo, o contexto brasileiro e mundial que influenciaram na proposta pela ampliação do ensino fundamental com ingresso aos seis anos, a legislação e normas que dispõem sobre esta política, e os objetivos e orientações do Ministério da Educação com a proposta, buscando sempre discutir esses documentos à luz da literatura pertinente. No capítulo a seguir serão apresentados e discutidos os resultados encontrados a partir da análise do material empírico, organizados nos principais temas abordados pelas pesquisas, conforme descrito no capítulo de Introdução deste trabalho. 


\section{O QUE MOSTRAM AS PESQUISAS EMPÍRICAS SOBRE O ENSINO FUNDAMENTAL DE NOVE ANOS}

Neste capítulo serão apresentados e discutidos os resultados encontrados a partir da revisão de literatura. Primeiramente, serão apresentados dados quantitativos relativos ao perfil das pesquisas que compõem esta revisão bibliográfica, organizados em quadros, tabelas, e gráficos para melhor visualização dos dados. Neste primeiro esforço de caracterizar os estudos, foram analisados dados como ano de publicação, local de realização da coleta de dados, técnica de coleta de dados utilizada, e participantes envolvidos. Assim, pretende-se mostrar o perfil das pesquisas empíricas na produção sobre o ensino fundamental de nove anos.

Posteriormente, serão apresentados e discutidos os principais resultados relatados pelos estudos analisados, dialogando com a literatura pertinente - leis, pareceres e documentos do Ministério da Educação, estudos teóricos sobre o ensino fundamental de nove anos, e bibliografia complementar pertinente ao tema. Com isso, neste segundo momento os principais tópicos a serem discutidos foram organizados em três grandes temas: (a) o processo de implantação do ensino fundamental de nove anos; (b) o referencial curricular do primeiro ano; e (c) o brincar no primeiro ano. Cada grande tema está subdividido em tópicos pertinentes à discussão do ensino fundamental de nove anos.

Para apresentar e ilustrar os resultados, buscou-se resgatar as pesquisas com maior abrangência (maior alcance dos resultados - envolvendo maior número de participantes), e pesquisas que apresentam dados (fotos, falas de profissionais da educação, depoimentos dos pais, desenhos das crianças, entre outros) relevantes e que esclareçam os resultados encontrados. Ademais, buscou-se apresentar todos os resultados encontrados, dando-se atenção tanto aos resultados mais relatados nas pesquisas, quanto àqueles que diferem da maioria. Esse esforço foi realizado na intenção de cumprir com o objetivo desta revisão de analisar o que as pesquisas relatam sobre a implantação do ensino fundamental de nove anos. 


\subsection{Perfil das pesquisas}

Conforme afirmamos ao expor os caminhos metodológicos realizados no desenvolver da pesquisa, foram selecionados para análise 84 trabalhos sobre o ensino fundamental de nove anos. Do total de 84 estudos, a maior parte é representada por dissertações de mestrado, compondo um grupo de 54 trabalhos. Os demais 30 trabalhos estão assim divididos: 17 artigos, oito teses, e cinco trabalhos apresentados na Anped. Cada trabalho que compõe esta revisão bibliográfica, seus respectivos autores, e o ano de publicação podem ser conhecidos nos quadros apresentados no Anexo 4, que estão organizados por ordem alfabética do sobrenome dos autores, para facilitar ao leitor a consulta durante a leitura do presente estudo.

Reunindo a informação sobre o ano de publicação dos trabalhos analisados, buscamos compreender como se distribuiriam as pesquisas encontradas no período de tempo de 2006 a 2012. A Figura 2 mostra o número de publicações ano a ano, de 2006 a 2012.

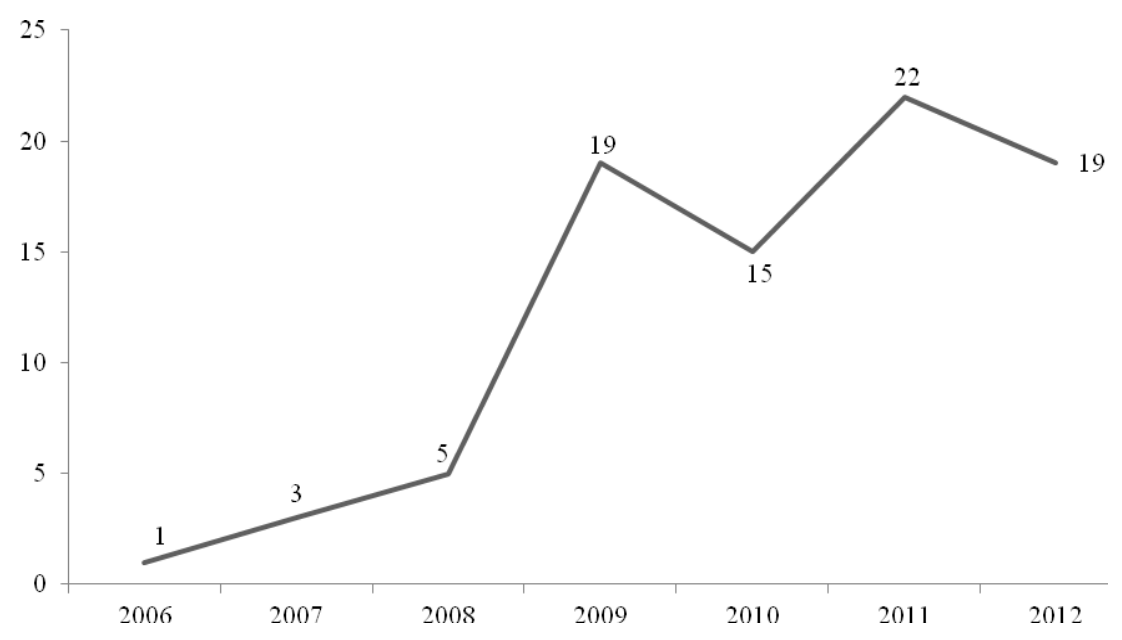

Figura 2. Evolução do número de trabalhos publicados de 2006 a 2012.

Fonte: A autora.

A Figura 2 mostra que os trabalhos constantes nessa revisão parecem refletir uma resposta à aprovação da Lei $n^{\circ} 11.274 / 06$ e sua consequente implementação, atingindo um maior volume de publicações em 2011. Estima-se que a concentração das publicações em 2011 deva-se ao fato de que a partir de 2010 era obrigatório que as escolas já estivessem adequadas à Lei $\mathrm{n}^{\mathrm{o}}$ 11.274/06, sendo maior alvo de discussão nesse período, o que pode ter impulsionado uma maior quantidade de trabalhos sobre o tema. Além disso, observa-se que nos três primeiros anos de vigência da Lei ${ }^{\circ}$ 11.274/06 (2006 a 2008), apenas 9 produções 
foram publicadas, enquanto nos anos seguintes o número de trabalhos publicados é oito vezes maior. Esse fato parece ser compreensível uma vez que a maior parte dos trabalhos que compõem esta revisão são dissertações e teses, trabalhos investigativos de longa duração que necessitam de um tempo considerável para que se tornem públicos.

Buscando compreender a abrangência dos estudos selecionados quanto a sua localização em território nacional, foi realizado o levantamento da região geopolítica em que foram coletados os dados de cada estudo. A Figura 3 mostra a distribuição dos artigos, teses e dissertações quanto à localização nas diferentes regiões do Brasil.

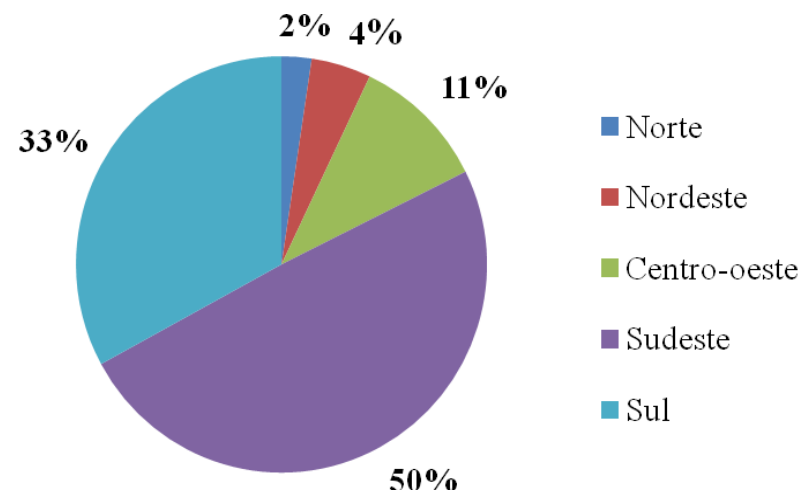

Figura 3. Distribuição dos estudos quanto à região de realização da coleta de dados. Fonte: A autora.

Observa-se pela Figura 3 que metade dos estudos da revisão teve como campo de pesquisa a região Sudeste, contabilizando 42 pesquisas. A região Sul foi a segunda de maior recorrência, com 28 estudos que realizaram a coleta nesta região. É importante ressaltar aqui que o trabalho de Silva e Scaff (2009), apresentado na 32 ${ }^{a}$ Reunião Anual da Anped, envolveu entrevistas com professores e familiares de alunos em duas regiões distintas: Nordeste e Centro-oeste. Assim, optamos por contabilizar essa mesma pesquisa duas vezes, e por consequência, as porcentagens apresentadas na Figura 3 contam com n=85.

Buscando conhecer de forma mais específica o local de coleta de dados e compreender como se dava a distribuição das pesquisas entre os estados de cada região, optou-se por realizar novo levantamento, agora considerando as unidades federativas do Brasil em que foram realizadas as coletas de dados das pesquisas (Tabela 4). 
Tabela 4. Distribuição quantitativa dos estudos segundo a Unidade Federativa em que foi realizada a coleta de dados.

\begin{tabular}{lc}
\hline \multicolumn{1}{c}{ Estado } & N \\
\hline São Paulo & 36 \\
Minas Gerais & 6 \\
Paraná & 11 \\
Santa Catarina & 8 \\
\hline Rio Grande do Sul & 8 \\
Goiás & 1 \\
\hline Distrito Federal & 3 \\
Mato Grosso & 2 \\
Mato Grosso do Sul & 4 \\
Bahia & 2 \\
\hline Alagoas & 1 \\
Pernambuco & 1 \\
Maranhão & 1 \\
Rondônia & 1 \\
\hline Total & $\mathbf{8 5}$ \\
\hline
\end{tabular}

Fonte: A autora.

Apesar das pesquisas, em sua maioria, serem realizadas em um único município, optou-se por agrupar quanto às unidades federativas porque em grande parte das pesquisas é omitido, por questões éticas, o nome do município estudado, sendo revelado o estado ou região do estado em que foi realizada a coleta de dados. Dos 84 trabalhos, apenas um não informou o estado em que os dados foram coletados, não sendo contabilizado no levantamento apresentado na tabela acima. Outros dois estudos realizaram a coleta de dados em dois estados diferentes: Silva (2012) realizou sua pesquisa no Distrito Federal e Mato Grosso, e Silva e Scaff (2009) realizaram a pesquisa na Bahia e Mato Grosso do Sul. Assim, esses dois estudos foram contabilizados duas vezes, o que explica o total igual a 85 apresentado na Tabela 4.

Este levantamento das pesquisas por unidade federativa de realização da coleta de dados permitiu observar um interessante dado: das 42 produções realizadas no Sudeste, 36 $(86 \%)$ foram realizada no estado de São Paulo. Apenas 6 estudos realizaram a coleta de dados no estado de Minas Gerais, e nenhum nos estados do Rio de Janeiro e Espírito Santo.

Já os estudos realizados no Sul e Centro-oeste encontram-se mais distribuídos pela região, havendo pesquisas feitas em todas as unidades federativas que compõem a região 
(respectivamente: Paraná, Santa Catarina, Rio Grande do Sul; e Goiás, Distrito Federal, Mato Grosso e Mato Grosso do Sul). A região Nordeste, que conta com 8 estados, foi campo de pesquisa de 5 estudos, realizados na Bahia, Alagoas, Pernambuco e Maranhão. Já na região Norte, encontramos apenas um estudo, realizado em Rondônia.

Esses dados obtidos no levantamento do local de realização das pesquisas corroboram os resultados de Rocha, Martinati e Santos (2012). Dos 25 trabalhos analisados pelas autoras, $48 \%$ foram produzidos na região Sudeste. Porém, as autoras não observaram tanta discrepância entre os estados dessa região, tendo encontrado 7 estudos realizados em São Paulo, e 5 em Minas Gerais. É importante ressaltar que as autoras fizeram a distribuição geográfica dos estudos que compunham a revisão a partir da instituição de pesquisa ao qual o trabalho estava vinculado. No entanto, Rocha, Martinati e Santos (2012) esclarecem que em apenas um dos estudos analisados o município de coleta de dados não correspondia com o local da instituição de ensino ao qual a pesquisa era vinculada, o que permite a comparação entre os dados desta pesquisa e os encontrados pelas autoras.

Para as autoras, essa maior concentração das produções na região Sudeste parece refletir a distribuição desigual de Programas de Pós-Graduação em Educação no Brasil, uma vez que $41 \%$ dos cursos estão localizados nessa região. Considerando-se que a maior parte dos trabalhos analisados na presente pesquisa constitui-se de dissertações de mestrado e teses de doutorado, esse fato parece explicar, ainda que parcialmente, a predominância dos estudos na região Sudeste.

É importante ressaltar que, com os dados revelados na Tabela 4, é possível constatar que os resultados e reflexões que serão apresentados na presente pesquisa refletem de forma mais intensa a realidade do estado de São Paulo, palco de quase metade das pesquisas analisadas (43\%). Além disso, com a Tabela 4 pode-se verificar a carência de pesquisas sobre o ensino fundamental de nove anos nas regiões Norte e Nordeste, assim como nas demais 13 unidades federativas que não constaram como campo de pesquisa dos estudos desta revisão. Assim, observa-se que apesar do considerável volume de publicações sobre o tema, elas ainda refletem a realidade vivenciada por uma pequena parcela do país.

Para compreender qual a forma de contato das pesquisas analisadas com relação ao contexto investigado, foi feito um levantamento dos instrumentos de coleta de dados utilizadas pelas pesquisas (Tabela 5). Para a realização deste levantamento, considerou-se apenas a pesquisa de campo, não sendo contabilizadas as pesquisas documentais e revisões de literatura que também foram realizadas em algumas teses, dissertações e artigos. Essa escolha 
deu-se por conta dos objetivos da presente pesquisa; considerando-se que a presente pesquisa trabalha com os resultados apontados pelas pesquisas que tratam do ensino fundamental de nove anos, torna-se relevante conhecer como as pesquisas empíricas tomaram contato com seus participantes ou local de observação.

Tabela 5. Caracterização das pesquisas quanto aos instrumentos de coleta de dados.

\begin{tabular}{lcc}
\hline \multicolumn{1}{c}{ Instrumentos de coleta de dados } & N & \% \\
\hline Observação & 8 & 9 \\
Questionário & 3 & 4 \\
Entrevista & 27 & 32 \\
Observação + questionário & 5 & 6 \\
Observação + entrevista & 28 & 33 \\
Questionário + entrevista & 6 & 7 \\
Observação + questionário + entrevista & 3 & 4 \\
Outros & 4 & 5 \\
\hline Total & $\mathbf{8 4}$ & $\mathbf{1 0 0}$ \\
\hline
\end{tabular}

Fonte: A autora.

Como se pode observar na Tabela 5, os instrumentos de coleta mais utilizados pelas pesquisas foram entrevistas (32\%) e a combinação de entrevistas com observações de campo (33\%). De forma geral, observa-se que a entrevista aparece em um total de 64 pesquisas $(76 \%)$.

Cabe comentar aqui que a técnica de entrevista apresenta algumas possibilidades e limitações na coleta dos dados. Ela possibilita ter acesso a mais informações, desde dados históricos que não poderiam ser observados no presente, até concepções e emoções vivenciadas no processo. Porém, vale ressaltar que a fala nem sempre reflete a prática. Como afirmam Rocha, Martinati e Santos (2012), exemplo disso são os casos em que se objetiva investigar o grau de importância atribuído pelos docentes às atividades lúdicas para as crianças de seis anos: nesses casos, a afirmação dessa importância nem sempre é acompanhada de uma prática docente que de fato valorize as brincadeiras. Nesse sentido, é importante ressaltar que os resultados que serão apresentados e discutidos neste trabalho refletem, em grande parte, as falas, discursos e concepções dos participantes. Mais adiante, serão apresentados os principais participantes das pesquisas que utilizaram a técnica da entrevista e/ou questionário para a coleta de dados, que, somadas, equivalem a 75 trabalhos. 
Analisando as pesquisas que envolveram observações no campo, podemos verificar que a maior parte delas focaram as observações nas turmas de primeiro ano, como é o caso das pesquisas de Aguiar (2012), Almeida (2012), Amaral (2008), Barbosa (2009), Brandão (2012), Carneiro (2006), Costa (2009), Delfin (2012), Dornelles (2011), Garcia (2012), Gil (2012), Kishimoto (2011), Klein (2011), Loureiro (2010), Raniro (2009), Rocha (2009), Scalzitti (2012), Silva (2010), Silva (2011), Souza (2012), e Zingarelli (2009).

A pesquisa de Abreu (2009) envolveu observações em sala de aula nas turmas de $1^{\circ}, 2^{\circ}$ e também $3^{\circ}$ anos do ensino fundamental, sendo a única a relatar observações nas demais turmas dos anos iniciais do ensino fundamental. Já as pesquisas de Purim (2010) e Tolentino (2007) também se distinguem das demais por envolveram observações do curso de formação oferecido aos professores de primeiro ano do ensino fundamental de nove anos.

Apenas seis pesquisas realizaram observações nas turmas de pré-escola e também nas turmas de primeiro ano: Nogueira (2011), Marcondes (2012), Mascioli (2012), Araujo (2008), Motta (2009), Schimitz (2008). Considera-se que este cuidado de observar ambas as turmas possibilita importantes contribuições para o debate da criança de seis anos no ensino fundamental. Assim, seria interessante, também, que houvessem mais pesquisas com este enfoque.

Na categoria "Outros" da Tabela 5 foram incluídos os trabalhos que se utilizaram como instrumentos de coleta de dados: a análise de registro de atividades da turma feita pela professora, como é o caso do estudo de Corrêa, R. C. P. (2011); encontros/conversas com grupo de crianças e produção de desenho, como se observa em Abreu (2010); história oral/depoimentos dos professores, utilizada por Tasca (2010); e narrativa dos professores, empregada na pesquisa de Bonamigo (2010).

Sabendo-se quais as formas de contato com a realidade das pesquisas empíricas, buscamos conhecer também quais teriam sido as vozes e fontes de informações que embasaram os seus resultados. Assim, fez-se um levantamento detalhado dos participantes ouvidos em entrevistas e questionários pelas 75 pesquisas que utilizaram estes instrumentos (Tabela 6). 
Tabela 6. Caracterização das pesquisas quanto aos participantes.

\begin{tabular}{lcc}
\hline \multicolumn{1}{c}{$\quad$ Participantes da pesquisa } & N & \% \\
\hline Professor & 22 & 29 \\
Aluno & 1 & 1 \\
Gestor da escola & 3 & 4 \\
Gestor de órgãos públicos & 3 & 4 \\
Pais/familiares dos alunos & 3 & 4 \\
Professor + gestor escolar & 11 & 15 \\
Professor + aluno & 1 & 1 \\
Professores + familiares & 3 & 4 \\
Professor + aluno + familiares & 2 & 3 \\
Professor + gestor de órgão público & 4 & 5 \\
Professor + gestor escolar + gestor de órgão público & 7 & 9 \\
Professor + gestor escolar + alunos & 2 & 3 \\
Professor + gestor escolar + familiares & 2 & 3 \\
Professor + gestor escolar + alunos + familiares & 2 & 3 \\
Professor + gestor escolar + gestor de órgão público + alunos & 2 & 3 \\
Gestor escolar + gestor de órgão público & 2 & 3 \\
Outros & 5 & 7 \\
\hline Total & $\mathbf{7 5}$ & $\mathbf{1 0 0}$ \\
\hline
\end{tabular}

Fonte: A autora.

A Tabela 6 permite constatar um interessante dado: o professor foi o grupo mais ouvido pelas pesquisas, aparecendo como participante em 58 das 84 pesquisas que compõem esta revisão, ou seja, 69\% das pesquisas. De forma contrastante, apenas 13 trabalhos envolveram as crianças como participantes da pesquisa, o que equivale a $15 \%$ do total (valor obtido ao somar todas as categorias que envolvem os alunos e mais três trabalhos da categoria "outros" em que as crianças foram participantes da pesquisa).

Esse dado parece refletir uma tendência em pesquisas empíricas de considerar apenas os adultos como informantes confiáveis, e, particularmente, os profissionais do ensino. É evidente a importância de ouvir a opinião daqueles que estão diretamente envolvidos com a atividade docente e com a escola. É evidente, contudo, que eles não são os únicos informantes chave do processo, em particular, os pais e as próprias crianças têm muito a dizer sobre o processo educacional. Esse dado mostra, assim, a importância de mais pesquisas que busquem ouvir esta população.

Ainda, constata-se com a Tabela 6 que os resultados das pesquisas desta revisão bibliográfica refletem em grande parte as concepções e discursos da equipe escolar, uma vez 
que as categorias de maior ocorrência de pesquisas são a de professores $(n=22)$, e professores+gestor escolar $(n=11)$, contabilizando, no total, $44 \%$ das pesquisas analisadas.

$\mathrm{Na}$ categoria "Outros" incluem-se as pesquisas que buscaram ouvir outros participantes que não constavam nas demais categorias. A pesquisa de Oliveira (2009) distingue-se das demais uma vez que, além de entrevistar técnicos da Secretaria Estadual de Educação, entrevistou dois conselheiros do Conselho Estadual de Educação (CEE), o presidente da UNDIME (União Nacional dos Dirigentes Municipais de Educação), o coordenador regional da SINEPE (Sindicato das Escolas Particulares) de Ponta Grossa, o presidente da Comissão de Educação da Assembleia Legislativa e um promotor da Justiça de proteção à infância.

O trabalho de Abreu (2009) também envolveu diferentes participantes, realizando entrevistas com os alunos, e aplicando questionários junto a três professores e um agente do CEMEPE (Centro Municipal de Estudos e Projetos Educacionais Julieta Diniz). Já a pesquisa de Mascioli (2012), além de entrevistar dois diretores (um de uma CER e outro de uma EMEF), cinco professores, e um coordenador pedagógico, entrevistou também duas merendeiras (uma da CER e outra da EMEF), que mantinham contato diário com as crianças de primeiro ano e puderam trazer colaborações para a pesquisa.

Gil (2012), em sua pesquisa em São Bernardo do Campo (SP), entrevistou a Secretária de Educação, a diretora de uma escola municipal, duas professoras de $1^{\circ}$ ano, 9 pais de alunos de $1^{\circ}$ ano, e 17 alunos de uma turma de $1^{\circ}$ ano. Além disso, entrevistou três membros do conselho da escola, buscando conhecer outras perspectivas acerca da implantação do ensino fundamental de nove anos nesta escola.

Jacomini, Rosa e Alencar (2012) também buscaram ouvir diferentes participantes de duas escolas, uma de Educação Infantil e outra de Ensino Fundamental. Os autores realizaram entrevistas com 43 alunos de $1^{\circ}$ ano, 14 pais, seis professores, quatro gestores escolares, dois membros do conselho de escola, dois representantes da SME e um representante do Sindicato de Funcionários da Prefeitura. Os trabalhos de Oliveira (2009) e Jacomini, Rosa e Alencar (2012) foram os únicos que buscaram ouvir representantes de sindicatos, sendo na primeira pesquisa estudado o Sindicato das Escolas Particulares do município estudado, e na segunda, o Sindicato de Funcionários da Prefeitura. 
Compreendidos os perfis dos trabalhos analisados quanto ao local, instrumentos e participantes da pesquisa, e as implicações disso para a presente pesquisa, inicia-se a seguir a discussão dos principais resultados relatados pelos estudos analisados.

\subsection{Processo de implantação do ensino fundamental de nove anos}

Pretende-se discutir neste tema aspectos referentes à implantação da política do ensino fundamental de nove anos, levando-se em conta as orientações do Ministério da Educação sobre a importância de readequar as escolas e formar os professores para o ensino fundamental de nove anos. Estas discussões estiveram presentes em quase todos os trabalhos analisados (à exceção de alguns que focaram sua análise no currículo e na discussão do que significa a criança de seis anos no ensino fundamental), aliadas à análise junto aos professores sobre sua participação no processo de implantação dessa política. Para discutir este tema, optamos por organizar o texto em três subtópicos: (a) participação dos professores no processo de implantação do ensino fundamental de nove anos; (b) formação docente para atuar no $1^{\circ}$ ano; e (c) mudanças e readequações da escola para receber as crianças de seis anos.

\subsubsection{Participação dos professores no processo de implantação do ensino fundamental de} nove anos.

No material analisado encontram-se relatos de professores, diretores, e supervisores escolares que trazem dados para compreender como se deu a participação destes no processo de implantação do ensino fundamental de nove anos.

Chaves (2012), em pesquisa realizada com professores e gestores escolares de uma escola municipal de Salvador (BA), reporta a ausência de discussão dessa política com os educadores, afirmando ser evidente, pelo discurso dos profissionais entrevistados, que as diretrizes e princípios do ensino fundamental de nove anos não foram devidamente debatidos com estes profissionais. O depoimento de uma coordenadora pedagógica participante da pesquisa ilustra esta realidade: 
Quando as decisões chegam para nós [é] de cima para baixo. Na verdade, houve uma má divulgação do Ensino Fundamental de nove anos. A rotina da escola é muito intensa e as orientações têm chegado muito tarde. Não conseguimos debater com os pais a tempo. Houve uma orientação subliminar e a escola faz aquilo que é possível. Os órgãos competentes não direcionam as discussões a quem mais interessa, que somos nós (CHAVES, 2012, p. 139).

Em pesquisa realizada por Antunes (2010) em Santa Maria em uma escola da rede municipal e uma escola particular, as professoras relatam que, em se tratando de políticas públicas, comumente os professores não são ouvidos ou consultados antes da aprovação da lei:

JOANA - Infelizmente as coisas sempre chegam de cima pra baixo. Deveriam nascer na base, ser pesquisado na realidade, e a partir da realidade surgir os questionamentos e a partir dos questionamentos buscarem soluções, mas não. Geralmente as coisas já vêm (p. 102).

JANA - Eu como professora, durante 34 anos eu nunca fui chamada para discutir uma política publica para as escolas estaduais de Santa Maria (p. 103).

Resultados semelhantes foram encontrados por Sant'anna e Guzzo (2009), em pesquisa realizada por meio de observações e entrevistas com quatro professores da rede municipal de uma cidade do interior paulista. As autoras também constataram a ausência de participação dos docentes no processo de implantação do ensino fundamental de nove anos, tendo sido esta a principal crítica das professoras entrevistadas a essa política. Segundo as pesquisadoras,

uma docente chamou a atenção para o fato de as reuniões realizadas com representantes da Secretaria Municipal de Educação apresentarem um caráter informativo, e não dialógico, com os professores da rede municipal de ensino (SANT'ANNA e GUZZO, 2009, p. 99).

O caráter apenas informativo dos cursos de formação, sem abertura para participação dos professores nas decisões, é também relatado por outras pesquisas da revisão. O trabalho feito por Jacomini, Rosa e Alencar (2012), cujo objetivo foi analisar a implementação do Ensino Fundamental de nove anos na rede municipal de Diadema, contou com dados de observações e entrevistas com 43 alunos de primeiro ano, 14 pais desses alunos, 6 professoras do primeiro ano, 4 gestores escolares, 2 membros do Conselho de Escola, 2 representantes da Secretaria Municipal de Educação e 1 representante do Sindicato dos Funcionários da Prefeitura de Diadema, totalizando 72 sujeitos. O estudo revela que tanto os profissionais da 
educação quanto a comunidade escolar afirmaram não ter participado de discussões sobre o ensino fundamental de nove anos, sendo apenas informados sobre as mudanças. Foram realizados pela Secretaria Municipal de Educação três seminários com os professores e gestores que, no entendimento destes, tiveram caráter apenas informativo e ainda foram insuficientes para o entendimento sobre como trabalhar com as crianças de seis anos.

Nas escolas investigadas pelos autores, coube à equipe gestora da escola informar aos pais sobre a ampliação do ensino fundamental. No entanto, em entrevista com os pais/responsáveis dos alunos de $1^{\circ}$ ano as autoras puderam observar que estes também se encontravam perdidos com relação a proposta do ensino fundamental de nove anos. Um dos pais/responsáveis afirmou: "foi o prézinho mesmo que avisou como ela tá bem evoluída, aí colocou ela com seis anos na primeira série, [...] que as crianças mais evoluídas iam para a primeira série" (JACOMINI, ROSA e ALENCAR, 2012, p. 237). Conforme afirmam as autoras, observa-se com este depoimento que a orientação passada aos pais foi insuficiente para que ficassem claros os motivos da antecipação do ingresso no fundamental aos seis anos de idade.

Almeida (2011), em pesquisa feita em três escolas municipais de São Paulo por meio de questionários enviados às equipes gestoras das três escolas e observações em campo, obteve o relato de uma das escolas que um dos desafios enfrentados foi o esclarecimento às famílias dos alunos sobre a alteração do ensino fundamental. Nesse sentido, segundo o autor, a equipe da escola faz o questionamento: "como aquele que não consegue compreender, poderia esclarecer os pais e sanar suas dúvidas"? (p. 173).

Nessa discussão, apresentamos as contribuições das pesquisas de Lima (2011) e Nogueira e Catanante (2011). Ambas mostram situações em que, apesar da aprovação das leis $\mathrm{n}^{\circ}$ 11.114/05 e 11.274/06 não terem envolvido a sua prévia discussão com professores, as decisões tomadas durante a implantação nas escolas pesquisadas envolveram ativamente todos os envolvidos: técnicos da Secretaria de Educação, gestores da escola, e professores.

O estudo de Lima (2011), buscando verificar as medidas e ações adotadas pela Rede Municipal de Ensino de Juiz de Fora (MG) para a construção da proposta curricular, envolveu observações em seis escolas da rede municipal e entrevistas com duas professoras, seis coordenadoras pedagógicas, uma diretora, e uma vice-diretora. A pesquisa mostra que no município mineiro houve espaço para participação dos professores nas decisões junto com a Secretaria Municipal de Educação, através da criação de grupos de discussão sobre a proposta. 
Os resultados das discussões e experiências foram posteriormente traduzidos em um relatório, publicado pela Secretaria de Educação para as escolas, com subsídios para implantação do ensino fundamental de nove anos, indicando experiências realizadas e soluções encontradas para algumas das dificuldades vivenciadas na implantação. Para Lima (2011), "com esse movimento que buscou o envolvimento de todos os professores interessados nos debates sobre o tema para a preparação do novo documento norteador, a SME-JF pretendeu estimular o debate e a construção coletiva da identidade institucional da escola” (p. 118).

A pesquisadora ressalta, ainda, que o documento orientador, contendo as propostas curriculares das diferentes disciplinas para a Rede Municipal, não visava "propor uma matriz curricular fechada, mas sim o resultado de uma reflexão teórico-prática, legitimada pelo envolvimento de todos os responsáveis pela educação no município” (p. 119).

No estudo de Nogueira e Catanante (2011), as autoras apresentam dados parciais de pesquisa realizada em quatro cidades do interior do estado de São Paulo. Por meio de entrevistas com seis professoras de $1^{\circ}$ ano, as autoras verificaram uma maior abertura para debate e participação dos educadores no processo de implantação do ensino fundamental de nove anos nas cidades investigadas. Nas entrevistas, as professoras enfatizam a preparação e a participação da equipe de profissionais da rede de ensino durante o processo de implantação da lei:

Foi, então, discutida a lei com a equipe gestora, a preparação das escolas para atender essa faixa etária (troca de mobiliário, colocação de parquinhos...) e, em relação aos professores, foram atribuídas essas salas com a obrigatoriedade de que dois HTPCs (hora de trabalho pedagógico coletivo) fossem na secretaria com o acompanhamento muito próximo dos coordenadores do centro de formação [da secretaria municipal de educação]. Nesses HTPCs era discutida a concepção de Educação, de criança, do desenvolvimento dessa faixa etária, e feito o planejamento de aulas com professores trocando experiências entre si, discutindo as dificuldades, avanços e atividades. ( $\mathrm{G}$ - Professora de EF e supervisora da rede de ensino - 12 anos de experiência) (p. 179).

Para as autoras, esta participação do professor é necessária para que ele ocupe o lugar de real ator do processo educacional. "Acreditamos que um dos maiores desafios do trabalho docente esteja justamente [...] na elaboração da profissionalidade docente diante das novas prescrições” (NOGUEIRA e CATANANTE, 2011, p. 188).

Portanto, as pesquisas de Lima (2011) e Nogueira e Catanante (2011) relatam realidades em que houve a preocupação em debater com os professores as decisões e 
caminhos possíveis na implantação do ensino fundamental de nove anos. Assim, a realização de grupos de discussão para a definição de diretrizes, abertos a todos os professores da rede (seja estadual, seja municipal), parece ser uma prática que traz importantes contribuições para que a implantação de políticas públicas seja adequada à realidade particular de cada município e de cada escola, abrindo espaço para que os professores tragam para discussão seus saberes e experiências, e também suas angústias e dúvidas.

Essa abertura para debate, porém, ainda é restrita, uma vez que ambas as pesquisas foram feitas em momentos de definição de medidas e ações a serem tomadas após decisão pela ampliação do ensino fundamental para nove anos, não se expandindo para o momento anterior à aprovação da Lei 11.274/06.

Segundo Jacomini e Klein (2010), pesquisas sobre a implantação e implementação de políticas educacionais têm demonstrado a necessidade das mesmas serem discutidas com os envolvidos no processo educativo, assim como a necessidade da participação da comunidade escolar para a efetivação da qualidade do ensino. Embora isso tenha sido disseminado por meio de variados estudos, de acordo com o estudo e análise do material publicado pelo Ministério da Educação e de acordo com estudos que analisam a implantação do ensino fundamental de nove anos, as leis n. ${ }^{\circ} 11.114 / 2005$ e n. ${ }^{\circ} 11.274 / 2006$ não foram devidamente debatidas com a comunidade escolar, como discutido no segundo capítulo desta dissertação.

Portanto, percebe-se que a falta de participação não resulta apenas uma suposta falta de gestão democrática interna à unidade escolar, mas também da forma hierárquica com que as políticas públicas são inseridas nas escolas. Com isso, é pertinente o questionamento de Maia e Camillo (2009), resultado de estudo sobre a percepção de diretores e vice-diretores sobre o ensino fundamental de nove anos:

Em que medida a participação é possível nas condições atuais que estruturam a sociedade e o sistema educacional - principalmente, quando pensamos que as próprias reformas e propostas não se originam da vontade e necessidade dos integrantes da comunidade educativa? (p. 156).

Para Almeida (2011), a forma como se deu a antecipação da idade e a ampliação do tempo do Ensino Fundamental e, sobretudo, a maneira como elas vêm sendo implantadas, “deixam a impressão de que o poder público deseja participação da comunidade nas questões que não interferem no sistema [...] Assim, torna-se duvidosa a existência de um sistema democrático porque as decisões importantes são tomadas sem ouvir as pessoas e sem uma instância onde as decisões possam ser questionadas" (p. 177-178). 
Ampliar a participação social nos conselhos e fóruns se configura em uma demanda fundamental para a efetivação do sistema nacional de educação, de forma a garantir o controle social sobre os investimentos públicos em educação e a participação da sociedade no planejamento e acompanhamento das políticas públicas (ALVES e ALVES, 2010). Para tanto, faz-se necessário uma concepção de gestão democrática que valorize a participação dos envolvidos no processo educativo, nas diferentes instâncias de elaboração, discussão e decisão das políticas educacionais (JACOMINI e KLEIN, 2010). Assim, é necessária uma efetiva participação dos interessados na tomada de decisões relativas às políticas públicas, bem como em sua implantação. Até porque, não é incomum que políticas educacionais bem fundamentadas e estruturadas não atinjam seus objetivos em função da não adesão por parte daqueles a quem cabe a sua implantação, em especial, a equipe escolar.

\subsubsection{Formação e preparação para os docentes do primeiro ano do ensino fundamental.}

Da mesma forma que a participação dos professores nos processos de decisão das medidas educacionais se faz relevante, a preparação e formação destes para atuar nesse processo de implantação de novas medidas é igualmente importante para que os objetivos sejam alcançados. Assim, buscou-se investigar o que as pesquisas mostram sobre a formação de professores no contexto de implantação do ensino fundamental de nove anos.

Nos documentos oficiais, o Ministério da Educação expressa preocupação com uma formação de professores que seja de qualidade e os prepare para a prática cotidiana de sala de aula. Além disso, reconhece que a mudança do ensino fundamental para nove anos demanda cursos de capacitação para os professores.

A ampliação do ensino fundamental demanda, ainda, providências para o atendimento das necessidades de recursos humanos - professores, gestores e demais profissionais de educação - para lhes assegurar, entre outras condições, uma política de formação continuada em serviço, o direito ao tempo para o planejamento da prática pedagógica, assim como melhorias em suas carreiras (BRASIL, 2007, p. 8).

Assegurar essa formação tem sido o desafio de todos os sistemas. Uma formação sensível aos aspectos da vida diária do profissional, especialmente no tocante às capacidades, atitudes, valores, princípios e concepções que norteiam a prática pedagógica. Promover a formação continuada e coletiva é uma atitude gerencial indispensável para o desenvolvimento de um trabalho 
pedagógico qualitativo que efetivamente promova a aprendizagem dos alunos (BRASIL, 2004, p. 26).

Portanto, no discurso do Ministério da Educação a formação de professores constituise a peça chave, indispensável, para promover melhoras na educação e a efetiva aprendizagem dos alunos. A proposta de um ensino fundamental com duração de nove anos visava justamente promover um desenvolvimento da educação brasileira, sendo, para isso, essencial investir na formação dos docentes.

Apesar das preocupações expressas nos documentos do Ministério da Educação em qualificar o professor para o trabalho com o primeiro ano do ensino fundamental de nove anos, a maior parte dos estudos evidencia a precária formação dos professores e a falta de planejamento (ABDIAN e CIARDELLA, 2011; AGUIAR, 2012; ALMEIDA, 2011; ANTUNES, 2010; ARAÚJO, 2008; ARELARO, JACOMINI e KLEIN, 2011; BARBOSA, 2009; CHAVES, 2012; CORREA, 2011; COSTA, 2009; DANTAS, 2009; FURTADO, 2009; GIL, 2012; HASHIMOTO, 2012; LEAL, 2011; LENCIONI, 2012; MASCIOLI, 2012; MOYA, 2009; PANSINI e MARIN, 2011; ROCHA, 2012; ROSA, 2011; SANT'ANNA e GUZZO, 2009; SILVA, 2009; SOUZA, 2012; TENREIRO, 2011; VARGAS, 2010; ZATTI, 2009). Para Moya (2009), esta ausência de uma preparação específica para o novo arranjo é preocupante, pois “a formação do professor tem implicação direta na prática pedagógica, e se ele não recebe estudo adequado [para assumir turmas de $1^{\circ}$ ano, com crianças de seis anos], não é capaz de assegurar o seu conhecimento, tampouco terá condições de realizar esse trabalho em sala de aula" (MOYA, 2009, p. 144).

Gorni (2007) realizou em sua pesquisa entrevistas junto a dois Núcleos Regionais de Ensino, oito Secretarias Municipais de Educação, e com diretores e professores de dez escolas municipais e duas escolas estaduais de diferentes cidades do interior do Paraná. A partir dos resultados encontrados com as entrevistas, a autora mostra que é grande a desinformação a respeito da proposta e a falta de preparo de escolas e professores para a sua implantação. Segundo a autora, "não se observa uma ação planejada, organizada e sistemática de assessoramento às escolas na implantação do EF ampliado, tanto no âmbito dos NREs quanto das SMEs" (GORNI, 2007, p. 74).

Abdian e Ciardella (2011), em pesquisa realizada no interior de São Paulo com entrevistas com o diretor e coordenador de uma escola municipal e com o diretor e coordenador de uma escola estadual, verificou o desconhecimento da proposta do Estado e 
falta de preparo dos diretores para implantação do ensino fundamental de nove anos. Segundo as autoras, a partir das falas dos profissionais entrevistados, observava-se uma antecipação para o primeiro ano das mesmas práticas utilizadas na antiga primeira série.

Em estudo realizado em uma rede municipal de educação do interior do estado de São Paulo, Correa (2011a) afirma que, no momento da implantação, os professores foram pegos de surpresa, sem consulta ou preparação prévia, e ainda, sem as condições adequadas para alcançar os objetivos propostos com a ampliação do ensino fundamental. Apenas após o início das aulas houve o oferecimento de formação aos professores por parte da Secretaria Municipal de Educação. Resultados semelhantes foram encontrados por Pansini e Marin (2011), em pesquisa realizada em Rolim de Moura, Rondônia. A exemplo do que ocorreu em algumas redes municipais e em outros estados do Brasil, na rede estadual de ensino de Rondônia o ensino fundamental de nove anos foi adotado imediatamente após a aprovação da Lei 11.274/2006, com início no ano letivo de 2007. As entrevistas com 44 professores do $1^{\circ}$ ao $3^{\circ}$ ano do ensino fundamental e com um gestor da Secretaria Estadual de Educação, realizadas de 2007 a 2009, mostram que nenhum tipo de formação docente foi oferecida nos três primeiros anos da implantação do ensino fundamental de nove anos. Em uma das entrevistas, uma professora afirmou:

"Professora 3: Não, já ouvi dizer que ia acontecer e, pronto! Começou este ano. A professora L., no ano passado, como era ela que estava com 6 anos, ela passou uma semana em um encontro sobre isso. Aí, já nós, que estamos com 6 anos este ano, não participamos de nenhuma discussão a respeito" (PANSINI e MARIN, 2011, p. 95).

O depoimento desta professora mostra outros problemas recorrentes: os cursos de formação muitas vezes são ofertados apenas uma vez, com duração demasiadamente curta (1 semana), e restrito aos professores que trabalham com o primeiro ano. Nesta situação, professores que assumem turmas de primeiro ano nos anos subsequentes ao curso acabam por não receber nenhuma formação para atuar no ensino fundamental de nove anos. Conforme afirma Zatti (2009),

[...] o aumento do número de matriculados dos anos iniciais a partir da introdução no primeiro ano do ensino fundamental acontecer aos seis anos de idade, requer não penas um número maior de professores atuando, mas, principalmente que tais professores sejam preparados e qualificados para tal (p. 73-74). 
Com tempo restrito, os cursos abordam especificamente a proposta do ensino fundamental de nove anos, sem oferecer subsídios teóricos para trabalhar novas concepções de criança, de infância, de alfabetização e letramento, de ludicidade, sem instrumentalizar o professor para novas práticas previstas na proposta do ensino fundamental de nove anos, e sem promover espaço para debater a política. Com isso, estes cursos pouco preparam o professor e assumem um caráter mais "informativo" do que "formador".

Em pesquisa realizada em Ponta Grossa (PR), Tenreiro (2011) constatou que no município uma das dificuldades relatadas na implantação do ensino fundamental de nove anos é a metodologia utilizada. Através de entrevistas com diretores, pedagogos e professores de oito escolas municipais (ao todo 32 participantes), a pesquisadora verificou que as diretoras e pedagogas apontam como dificuldade o fato de que o curso de formação não é oferecido diretamente ao professor, e sim aos diretores e pedagogos para repassarem para as escolas.

Nós quando voltamos para a escola, fazemos o repasse, mas não é a mesma coisa da própria pessoa que dá o curso. As professoras sempre são chamadas para um curso ou outro. Mas, normalmente somos nós que participamos (Pedagoga 3) (p. 196).

Isso é um desafio, eu enfrento muito isso aqui, nós enquanto escola percebemos que o professor pede. O município não tem oportunizado. Acontece assim, eles repassam para a gente, nós temos a formação de pedagogo e diretores e a gente é que repassa para os professores. Específico para os professores não tem. Às vezes um projeto ou outro, uma palestra (Pedagoga 1) (p. 197).

Segundo Tenreiro (2011), as professoras disseram considerar importante a formação, especialmente pela troca de ideias com outras professoras. A autora afirma, a partir das falas das professoras, que foram dadas poucas orientações pela Secretaria Municipal de Educação de Ponta Grossa (PR) sobre o ensino fundamental de nove anos, e as professoras relataram estarem perdidas quanto às mudanças. Uma das professoras participantes da pesquisa afirmou:

Eu não recebi nenhuma orientação de como deve ser o trabalho. A secretaria não fez nada. Foi mais pela experiência que eu já tinha na Educação Infantil.

[...]

A única coisa que ficou bem claro foi que deve ser trabalhado o lúdico, respeitar as necessidades deles, não chocar as crianças, como por exemplo: aqui você não pode chupeta! Aqui não tem mamadeira! Aqui não vai dormir! Foram orientações mais básicas (TENREIRO, 2011, p. 134). 
Com isso, observa-se que ainda é grande a desinformação sobre a proposta do ensino fundamental de nove anos e as mudanças nas práticas pedagógicas envolvidas. Além disso, é possível observar distorções na concepção de criança e suas necessidades, entendo por necessidades infantis o uso da chupeta e da mamadeira.

O estudo realizado por Lencioni (2012), cujo objetivo era discutir a formação docente no contexto do ensino fundamental de nove anos, mostra também a necessidade de maior investimento e planejamento na formação docente, atentando para a necessidade de maior espaço para diálogo nos momentos de formação. A pesquisa foi realizada em Limeira (SP), município que implantou a política em 2009, por meio de observação de momentos de formação (HTPC) e de entrevistas com professoras e com a coordenadora da escola municipal acompanhada. Segundo a coordenadora da escola, houve reuniões da SME com as coordenadoras da rede municipal por quatro dias para anunciar a mudança, mas que isso não foi suficiente para compreender o que deveria ser feito e ainda repassar para as professoras. A coordenadora afirma ainda que, em meio à desinformação, desorganização e despreparo para o trabalho com o $1^{\circ}$ ano, as professoras não queriam assumir as turmas de crianças de seis anos, "porque ninguém sabe o que é. Porque o novo assusta, né? O novo assusta, você [precisa] se desacomodar" (LENCIONI, 2012, p. 93).

Para Capunhinho (2007), o professor é elemento central para uma mudança efetiva. Em pesquisa realizada com questionários e entrevistas com nove professores da rede municipal de uma cidade da Grande São Paulo (nome não informado), a autora verificou que a formação oferecida pouco modificou as concepções e algumas práticas dos docentes. Uma professora entrevistada afirmou sobre o planejamento: "Eu não mudei. O mesmo planejamento que eu tinha eu usei, só que eu puxei mais para a brincadeira, para não deixar a criança no caderno o tempo todo, fazendo atividade na linha do caderno" (CAPUCHINHO, 2007, p. 100). A partir de seus resultados, a autora compreende que não apenas o curso de formação não mobilizou os docentes para as mudanças necessárias, mas que também estes se encontravam desmotivados e pouco se mobilizaram para "contribuir de maneira eficaz com as iniciativas que podem trazer benefícios reais à educação" (CAPUCHINHO, 2007, p. 118). Com isso, a autora conclui que para que mudanças efetivas ocorram na educação,

é imperativo que o professor deixe de lado conhecidos chavões, como por exemplo: "Não recebo formação suficiente" e adote uma postura mais investigativa acerca de todo o processo, que procure leituras e informação, além das já recebidas nas escolas, e, sobretudo, que busque nos saberes que 
já têm - teóricos e práticos - novas possibilidades de ação, o que trará, inclusive, novos saberes e novas práticas e assim por diante (p. 117).

Assim, a autora reconhece a necessidade de serem oferecidas condições para o trabalho docente, porém, ressalta que a formação é contínua, diária, e não se dá apenas em momentos específicos.

Frente à posição da autora, cabe comentar que o professor é, de fato, elemento central para que as mudanças idealizadas pelas políticas se concretizem, sendo necessário que sejam dadas as condições para seu trabalho e que estes, vendo-se como importantes atores na educação, se mobilizem para contribuir para que as melhorias idealizadas se concretizem. Porém, considera-se também que, dado todo o contexto de implantação das políticas educacionais, geralmente impostas sem participação dos docentes, é utópico imaginar que os docentes possam "abraçar uma causa" que pouco conhecem. Assim, entende-se que os cursos de formação assumem o papel de formar o educador e mobilizá-lo para as mudanças preconizadas pelas políticas que estão sendo implantadas.

Ainda nesta discussão, considera-se bastante interessante os resultados encontrados na pesquisa de Abreu (2009). Visando analisar a implantação do ensino fundamental de nove anos em Uberlândia (MG), a autora realizou observação participante e entrevistas com 3 professoras de uma escola da rede municipal (uma professora do $1^{\circ}$ ano, outra do $2^{\circ}$ ano, e outra do $3^{\circ}$ ), com alunos destas professoras, e com um agente do CEMEPE (Centro Municipal de Estudos e Projetos Educacionais Julieta Diniz) de Uberlândia, profissional responsável pelo curso de formação ofertado na rede. A pesquisa mostra que, no município estudado, adotou-se o ensino fundamental de nove anos a partir de 2007, e em novembro de 2006 foi ofertado curso de formação para os docentes que assumiriam as turmas de $1^{\mathrm{o}}$ e $2^{\mathrm{o}}$ anos, denominadas de "série introdutória" e "1a série". Com a mudança, a rede passou a adotar um material desenvolvido para orientar o trabalho pedagógico nos três primeiros anos do ensino fundamental. Assim, nota-se que apenas os professores de $1^{\circ}$ e $2^{\circ}$ ano receberam formação, no entanto, os docentes de $3^{\circ}$ ano também tiveram que modificar suas práticas (mobilizadas em virtude do novo material adotado).

A partir das entrevistas com as docentes realizadas em sua pesquisa, Abreu (2009) constata que o fato de não ter participado do curso de formação ofertado pela rede pode ter contribuído para que a professora do $3^{\circ}$ ano avaliasse a mudança como uma ação impositiva. Conforme posicionamento de professora do $3^{\circ}$ ano entrevistada na pesquisa, "a implantação 
pode favorecer, mas a prática pedagógica precisa ser repensada para não aumentar ainda mais o caos instalado na educação, por conta de tantas propostas impostas sem um estudo prévio" (ABREU, 2009, p. 101). Em contrapartida, uma professora do $2^{\circ}$ ano, que participou da formação ofertada pela rede, demonstrou entusiasmo e otimismo com a proposta: "Acredito na mudança da educação e também no crescimento dos educandos que terão no Ensino Fundamental um ano a mais, no ensino obrigatório" (ABREU, 2009, p. 101).

A pesquisa de Abreu (2009) revela a importância do curso de formação para orientar e também mobilizar os professores na busca pela concretização de melhorias idealizadas nas políticas. Por outro lado, alerta para a necessidade de envolver também os demais docentes alfabetizadores no curso de formação para um trabalho unificado, "rompendo assim com encaminhamentos contraditórios que quase sempre resultam em ações fragmentadas no interior da escola" (ABREU, 2009, p. 151).

As situações descritas nos trabalhos de Purim (2010) e Klein (2011) se configuram como experiências em que houve melhor planejamento na oferta da formação continuada. Em ambas as situações, o curso ofertado ocorreu ao longo de todo o ano letivo e envolveu "atividades práticas" para os professores, em que estes tinham a oportunidade de modificar suas práticas aplicando os novos saberes promovidos pelos cursos de formação, e posteriormente debater suas dúvidas e dificuldades com o profissional formador/tutor.

O estudo de Purim (2010) ocorreu no município de Timbó (SC), que implantou o ensino fundamental de nove anos no ano de 2007, e envolveu observação do curso de formação ofertado pela rede municipal neste mesmo ano e envio de questionário a 10 professores de primeiro ano e 5 coordenadores pedagógicos da rede municipal. Conforme afirma a autora, a rede municipal de Timbó desejava com o curso de formação construir com os profissionais diretamente envolvidos com as turmas de alfabetização um referencial curricular para o $1^{\circ}$ ano do ensino fundamental de nove anos. Para isso foi oportunizado espaço para as discussões e foi contratado um mediador, especialista em currículo e planejamento infantil e vinculado com a universidade. Assim, além do professor de primeiro ano, participaram das discussões também os demais professores alfabetizadores e coordenadores pedagógicos.

Segundo Purim (2010), os encontros realizados eram quinzenais, e já a partir do primeiro encontro os professores das turmas de alfabetização e os coordenadores pedagógicos assumiram o compromisso de organizar e registrar os planejamentos das turmas, apresentando-os nos encontros subsequentes para avaliação, discussão e reflexão do grupo: “o 
grupo avaliava as estratégias adotadas, as seleções de conteúdos e se durante aquela quinzena os objetivos propostos haviam sido alcançados" (PURIM, 2010, p. 49). Para a autora, "neste espaço de formação, os profissionais trouxeram à tona suas concepções e tiveram a oportunidade de redimensionar suas ações ancoradas nas representações do grupo" (PURIM, 2010, p. 27). A partir das discussões e práticas realizadas no curso de formação, foi elaborado, ao final do ano letivo, o Referencial Curricular para o $1^{\circ}$ ano do ensino fundamental de nove anos adotado pela rede municipal de Timbó (SC).

Ainda que o curso de formação continuada ofertado na rede municipal de Timbó (SC) tenha ocorrido no mesmo ano da implantação do ensino fundamental de nove anos, a forma como este foi estruturado oferece elementos para se pensar em uma experiência de formação continuada ideal na implantação de novas políticas públicas na educação. Além de ter sido ofertado subsídios teóricos para os profissionais, o curso abriu espaço para debates e a construção democrática de um novo referencial curricular. Não se restringindo aos professores do primeiro ano, possibilitou uma ação unificada entre os professores alfabetizadores. Por fim, ao envolver situações práticas de ensino - estruturando em conjunto os objetivos, conteúdos e estratégias - e a possibilidade de debatê-las, promove o “desacomodar" do professor e possibilita mudanças concretas em suas práticas escolares. Como afirma Purim (2010), "a consolidação dos saberes e da ação docente reside na própria familiarização por meio da experiência” (p. 78).

Já a experiência descrita por Klein (2011) foi vivenciada pela rede municipal da capital paulista. Apesar de não ter sido permitida a acompanhar o curso de formação ofertado por não ser professora de $1^{\circ}$ ano, a pesquisadora teve acesso a muitas informações sobre sua estrutura e conteúdo temático. Segundo ela, o curso ofertado - entitulado "A criança de seis anos no Ensino Fundamental" - foi desenvolvido pela Fundação Santilla ${ }^{6}$ e ocorreu no modelo EAD (ensino à distância), sendo acessado via internet por meio de senha pessoal. Segundo Klein (2011), o curso foi organizado em 20 módulos, sendo indicado dedicação de 4 horas para cada módulo, totalizando 80 horas ao longo do ano. Assim, observa-se que este foi um curso extenso, exigindo maior dedicação e envolvimento dos docentes em formação.

A autora detalha como estava organizado o curso:

\footnotetext{
${ }^{6}$ Segundo Klein (2011), a Fundação Santillana é uma fundação vinculada a editoras brasileiras (como a Objetiva) e possui parcerias com a UNESCO.
} 
Cada módulo seguia a mesma estrutura contendo uma videoaula, slides para download, leitura de textos obrigatórios. Os participantes do curso contavam com uma tutora, que via internet poderia auxiliar com eventuais dúvidas e um fórum de discussão online para que os participantes do curso trocassem experiências. Em seguida, cada módulo apresentava um item intitulado "construção da prática pedagógica" onde era solicitado o envio pelas professoras de alguma atividade (p. 154).

Segundo Klein (2011), a professora participante da pesquisa afirmou que o curso havia provocado mudanças em sua maneira de pensar as práticas escolares, em especial quanto ao brincar como forma de ensinar.

A pesquisa de Klein descreve uma situação bastante diferente das vivenciadas nos demais municípios. Apesar de se restringir aos professores de primeiro ano e ser oferecido na modalidade $\mathrm{EAD}$, que muitas vezes acaba por promover pouco espaço de reflexão e debate, o curso parece ter possibilitado mudanças nas práticas pedagógicas das docentes por solicitar a execução de atividades em sala de aula que envolvessem as orientações e conceitos trabalhados no curso.

Os trabalhos analisados para esta revisão, em geral, discutem o curso de formação a partir das falas dos profissionais entrevistados, trazendo poucas informações sobre os conteúdos abordados nos cursos. Mesmo os estudos que tiveram a oportunidade de acompanhar os cursos de formação (PURIM, 2010; LENCIONI, 2011; AGUIAR, 2012) não trazem informações precisas sobre os conteúdos abordados. Encontramos nesta revisão apenas dois estudos que fizeram esta investigação dos conteúdos abordados nos cursos de formação: Klein (2011) e Abreu (2009). Antes de finalizar este capítulo, será discutida essa questão dos conteúdos dos cursos de formação, apoiando-se nestes dois trabalhos.

Klein (2011) e Abreu (2009) tiveram acesso ao conteúdo temático desenvolvido nos cursos de formação de diferentes formas. Klein (2011) conseguiu as informações em entrevista com uma professora de primeiro ano que estava começando o curso e lhe passou o material de apresentação do curso. Abreu (2009) conseguiu informações em entrevista com o responsável pelo curso de formação das professoras.

Ao analisar os conteúdos do curso, ambas as pesquisadoras constataram uma ênfase nos temas sobre alfabetização no primeiro ano, dentre os demais temas trabalhados nos cursos. Os Quadros 6 e 7 mostram o conteúdo temático trabalhado em cada módulo dos cursos de formação ofertado para os professores de $1^{\circ}$ ano. 
Quadro 6: Conteúdo temático do curso de formação oferecido para professores de $1^{\circ}$ pela rede municipal de São Paulo (SP).

\begin{tabular}{|c|c|c|}
\hline Parte & Item & Módulo \\
\hline I & $\begin{array}{l}1 \text {-A criança de } 6 \text { anos no } \\
\text { Ensino Fundamental de } 9 \text { anos }\end{array}$ & $\begin{array}{l}1 \text { - Legislação e orientaçôes do MEC } \\
2 \text { - Teorias da aprendizagem; processos cognitivos e características } \\
\text { da criança de } 6 \text { anos. }\end{array}$ \\
\hline I & $\begin{array}{l}2 \text { - Organização de espaço e } \\
\text { tempo }\end{array}$ & $\begin{array}{l}\text { 3- Organização de "Cantos de Atividades Diversificadas" - como e } \\
\text { porque organizá-los } \\
\text { 4- Implantaçăo da atividade permanente "cantos de Atividades } \\
\text { Diversificadas"; Planejamento e encaminhamento; Organização de } \\
\text { espaço e materiais. } \\
5 \text { - Organização do cotidiano pedagógico; Planejamento; } \\
\text { Organizaçåo de rotina; Atividades permanentes. }\end{array}$ \\
\hline I & 3 -Brincar e brincadeiras & $\begin{array}{l}6 \text { - O jogo simbólico; jogo e cultura; criação de ambientes lúdicos } \\
7 \text { - As brincadeiras; jogos e brincadeiras tradicionais; Os jogos e o } \\
\text { movimento; Os jogos e a vida em grupo. }\end{array}$ \\
\hline II & 4 - Alfabetização Inicial & $\begin{array}{l}8 \text { - Alfabetização e Cidadania; Planejando uma rotina de trabalho; } \\
\text { Diagnóstico; o trabalho com nome próprio. } \\
9 \text { - Oralidade; Situaçóes de conversa no cotidiano; Situaçóes } \\
\text { formais de conversa; Práticas de comunicaçâo em sala de aula. } \\
10 \text { - Leitura; Leitura pe lo professor; Leitura pela criança; práticas } \\
\text { de leitura em sala de aula. } \\
11 \text { - Produção textual; Práticas de escrita em sala de aula. }\end{array}$ \\
\hline II & $\begin{array}{l}5 \text { - Jogos e resoluçắo de } \\
\text { problemas }\end{array}$ & $\begin{array}{l}12 \text { - O jogo como estratégia de ensino; Encaminhamentos e } \\
\text { intervençő́s do professor. } \\
\text { 13- Construção do número pela criança; Leituras e escritas } \\
\text { numéricas } \\
14 \text { - Resolução de problemas. }\end{array}$ \\
\hline II & 6 - Expressão Plástica & $\begin{array}{l}\text { 15- Linguagem Visual; Desenho; O desenho se planeja. } \\
\text { 16- Ver e fazer arte. }\end{array}$ \\
\hline II & 7 - Conhecimento de mundo & $\begin{array}{l}\text { 17- Ciências Naturais; Linguagem e Ciências Naturais; Planejare } \\
\text { desenvolver atividades na interface Ciências e Linguagem. } \\
18 \text { - Ciências Sociais; Linguagem e Ciências Sociais; Planejar e } \\
\text { desenvolver atividades na interface Ciências e Linguagem. }\end{array}$ \\
\hline III & & 19 - Registro e construçã̃o de portifólios. \\
\hline IV & & 20- Parceria ente escola, familia e sociedade \\
\hline
\end{tabular}

Fonte: Klein (2011), p. 155. 
Quadro 7: Conteúdo temático do curso de formação oferecido para professores de $1^{\circ}$ ano pela rede municipal de Uberlândia (MG).

\begin{tabular}{|l|l|}
\hline MÓDULO: & TEMA: \\
\hline $1^{\circ}$ Módulo & Organização espaço temporal e currículo. \\
\hline $2^{\circ}$ Módulo & $\begin{array}{l}\text { Leitura Teorias e práticas de leitura } \\
\text { observando as capacidades propostas pelo } \\
\text { CEALE. }\end{array}$ \\
\hline $3^{\circ}$ Módulo & $\begin{array}{l}\text { Práticas de leitura - Oficinas: Histórias } \\
\text { infantis e Trabalhando com o jornal. }\end{array}$ \\
\hline $4^{\circ}$ Módulo & $\begin{array}{l}\text { Práticas de leitura - Oficinas: Histórias } \\
\text { infantis e Trabalhando com o jornal. }\end{array}$ \\
\hline $5^{\circ}$ Módulo & $\begin{array}{l}\text { A Infância e a Importância do Brincar nas } \\
\text { Séries Iniciais (Palestra). }\end{array}$ \\
\hline $6^{\circ}$ Módulo & Escrita: teoria e prática. \\
\hline $7^{\circ}$ Módulo & $\begin{array}{l}\text { Produção de texto: oral e escrito - } \\
\text { Oficinas: Dobradura e recortes - Teatro e } \\
\text { Música. }\end{array}$ \\
\hline $9^{\circ}$ Módulo & $\begin{array}{l}\text { Produçåo de texto: oral e escrito - } \\
\text { Oficinas: Dobradura e recortes - Teatro e } \\
\text { Música. }\end{array}$ \\
\hline & Educação Matemática. \\
\hline & \\
\hline
\end{tabular}

Fonte: Abreu (2009), p. 54-55.

O Quadro 6, referente ao curso de formação da rede municipal da capital paulista, revela maior diversidade nos temas abordados no curso do que o Quadro 7, referente à formação ofertada pela rede municipal de Uberlândia (MG). Vale ressaltar que o curso ofertado pela rede municipal de Uberlândia contou com um total de 40 horas (ABREU, 2009), enquanto que o de São Paulo teve duração 80 horas (KLEIN, 2011). Em ambos os casos, foram abordados temas como organização de espaço e de tempo, leitura e escrita, o brincar, e educação matemática. O Quadro 6 se destaca por incluir o módulo Conhecimento de Mundo, em que foi ofertada formação para o ensino de conhecimentos de Ciências Naturais e Ciências Sociais no $1^{\circ}$ ano. 
Segundo Klein (2011), cada módulo envolvia 4 horas de dedicação. Assim, observa-se com o Quadro 6 que foram destinadas 28 horas para aspectos mais gerais (conhecimentos teóricos, organização do espaço e tempo, avaliação e relação com família) e 52 horas para os campos do conhecimento, incluindo aqui os jogos e as brincadeiras. Dessas 52 horas, 20 horas foram destinadas à alfabetização, 12 horas para matemática, 8 horas para o brincar, 8 horas para o conhecimento de mundo e 8 horas para expressão plástica ${ }^{7}$. Também no Quadro 7 observa-se que seis dos nove módulos abordaram o processo de alfabetização. Pode-se afirmar, com isso, que embora os cursos tenham inserido diversos aspectos do cotidiano escolar nas temáticas abordadas, houve uma maior valorização na formação destinada à alfabetização inicial das crianças de seis anos.

Buscou-se trazer para a discussão da formação docente no contexto do ensino fundamental de nove anos diversos estudos que mostram situações representativas de muitos municípios, assim como estudos que relatam situações que se diferenciam das demais. Assim, buscou-se discutir as dificuldades encontradas, e refletir sobre as experiências positivas, a fim de contribuir para propostas futuras de formação continuada na implantação de políticas públicas na educação. Discutiu-se a importância de um curso de formação de qualidade para formar e preparar o professor na busca pela concretização das melhorias idealizadas pelas leis. Finalizando este capítulo, apresenta-se a fala de André (2004), que exprime a importância da formação docente e da oferta de condições para essa formação:

[...] se queremos formar um professor que seja consciente, crítico atuante e tecnicamente competente é preciso dar condições, na sua formação, para que ele vivencie situações que o levem a incorporar essas habilidades e comportamentos... experiências e vivências que os levem a alterar suas práticas de ensino (apud Tenreiro, 2011, p. 17).

\subsubsection{Mudanças e readequações da escola para receber as crianças de seis anos}

Como já discutido, para a inclusão da criança de seis anos no ensino fundamental são necessárias adequações das escolas para atender as necessidades desta faixa etária. Segundo o Ministério da Educação, as mudanças estruturais do ambiente escolar são de extrema relevância para uma adequada implantação do ensino fundamental de nove anos. Para atender

\footnotetext{
${ }^{7}$ Cabe ressaltar, no entanto, que por ser ofertado na modalidade EAD, não há garantia de que estas horas de dedicação foram cumpridas.
} 
as necessidades da criança de seis anos e acolhê-las no espaço escolar, seriam necessárias novas salas de aulas, carteiras escolares, livros didáticos e diferentes recursos lúdicos, com variedades de jogos e brinquedos (BRASIL, 2004a; BRASIL, 2007c). Assim, para que sejam desenvolvidas de forma efetiva as diferentes áreas do conhecimento, "as condições do espaço, organização, recursos, diversidade de ambientes internos e ao ar livre, limpeza, segurança etc. são fundamentais" (BRASIL, 2007c, p. 67).

As pesquisas empíricas analisadas apontam para a necessidade de maiores investimentos e mobilização de recursos para realizar as modificações necessárias à implantação do ensino fundamental de nove anos. De uma forma geral, o estudos apontam que, embora algumas modificações tenham sido feitas, estas não foram significativas, e o ambiente escolar continua inadequado para as crianças de seis anos (ARAÚJO, 2008; ARELARO, JACOMINI e KLEIN, 2011; BEZERRA 2011; CORREA, 2010; CORREA, 2011; COSTA, 2009; GIL, 2012; GORNI, 2007; HASHIMOTO, 2012; JACOMINI, ROSA e ALENCAR, 2012; LEAL, 2011; LIMA, 2011; LOUREIRO, 2010; MASCIOLI, 2012; MIRANDA, 2012; MOYA, 2009; NOGUEIRA, 2011; NOGUEIRA e CATANANTE, 2011; PANSINI e MARIN, 2011; SANT'ANNA e GUZZO, 2009; SILVA, 2009; SILVA, 2011; SOUZA, 2012; TENREIRO, 2011).

Os estudos de Correa (2010) e Pansini e Marin (2011) evidenciam esta realidade, chamando atenção para o fato de que, nas escolas investigadas - escolas municipais do interior de São Paulo e escolas estaduais de Rondônia, respectivamente - começaram a chegar os mobiliários adaptados bem como jogos e brinquedos foram adquiridos somente dois anos após a matrícula das crianças de seis anos nas escolas (CORREA, 2010; PANSINI e MARIN, 2011).

Souza (2012), em pesquisa desenvolvida em Dourados (MS), realizou observações em duas escolas municipais, além de entrevistas com dois professores de $1^{\mathrm{o}}$ ano, dois coordenadores pedagógicos e dois técnicos da Secretaria Municipal de Educação. Os resultados encontrados evidenciam a falta de adequação do mobiliário para as crianças de seis anos, conforme mostra a Figura 4. 


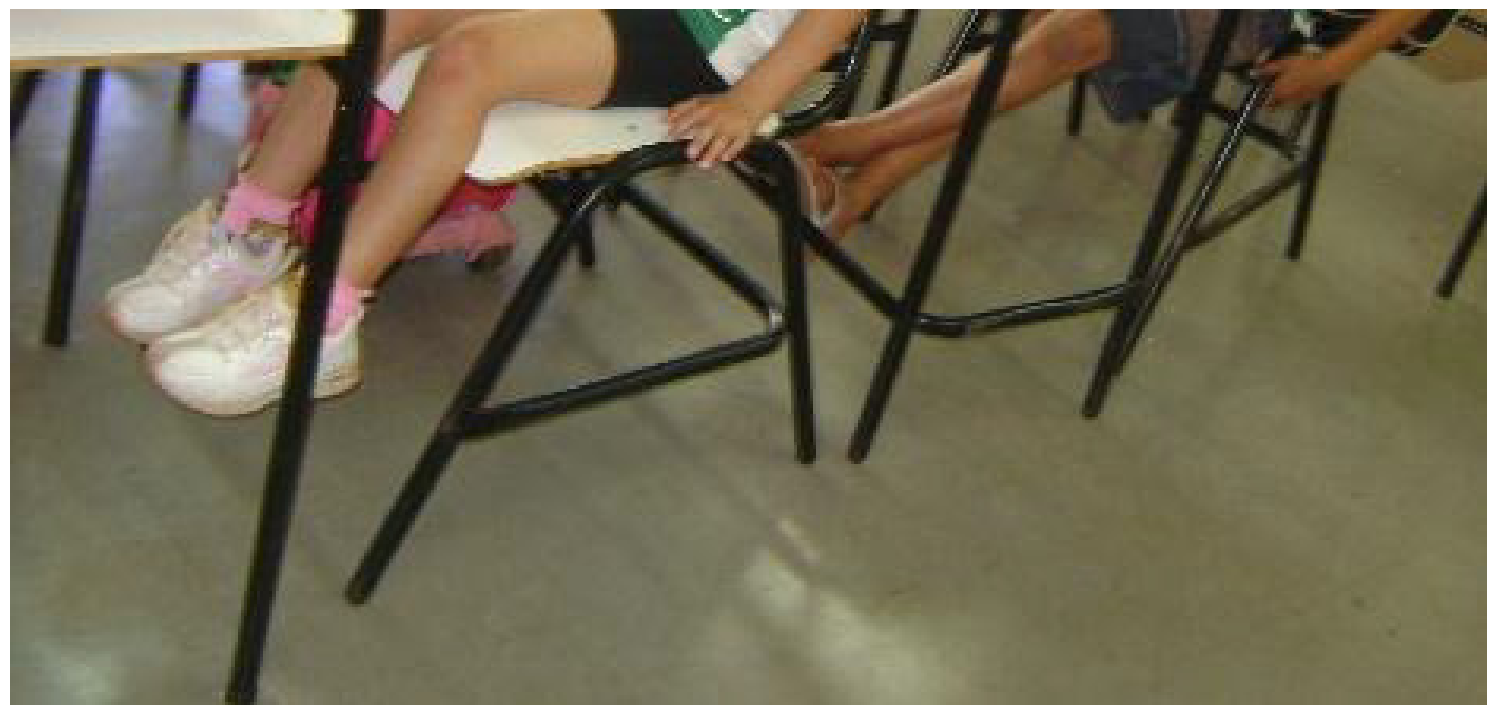

Figura 4. Inadequação do mobiliário para criança de seis anos: pés suspensos.

Fonte: Souza (2012), p. 89.

A foto registrada pela autora mostra a inadequação do mobiliário para o tamanho das crianças de seis anos, que não conseguem encostar os pés no chão enquanto estão sentadas nas carteiras, e assim permanecem por muito tempo (SOUZA, 2012). As professoras entrevistadas demonstraram preocupação com esta situação, como se observa no relato de uma delas:

Eu vejo que as salas de aula não são adequadas. As carteiras são inadequadas para a faixa etária, porque elas são para uma idade e as crianças muitas vezes ficam nas cadeiras com os pezinhos pendurados, isso é errado. Além disso, é cansativo para elas, pois ficam com os pés pendurados por aproximadamente quatro horas (PROFESSORA I). (SOUZA, 2012, pág 87).

Além da inadequação do mobiliário, Souza (2012) reporta também a inexistência de espaços lúdicos como parque e brinquedoteca. Outra professora entrevistada ressalta que, na escola em que trabalha, também não teve nenhuma mudança quanto à estrutura física:

Continuamos com o mesmo espaço físico que a gente estava recebendo essas crianças antes da ampliação do Ensino Fundamental. Já fizemos dois projetos que foram entregues para as autoridades locais reivindicando investimentos no espaço infantil, pedimos banheiros, salas adequadas e também um parque infantil, mas até agora nada (PROFESSORA II) (SOUZA, 2012, p. 90).

Costa (2009) objetivou em seu estudo investigar o lugar da criança de seis anos no Ensino Fundamental de nove anos, por meio de observação participante do cotidiano escolar 
em uma escola da rede municipal de Goiânia (GO). Ao observar o ambiente escolar, a pesquisadora também verificou inadequação do espaço físico para as crianças menores. Como Souza (2012), a autora também observou que as carteiras são grandes para as crianças de primeiro ano, e muitas acabam ficando com os pés no ar, como mostra a Figura 5.

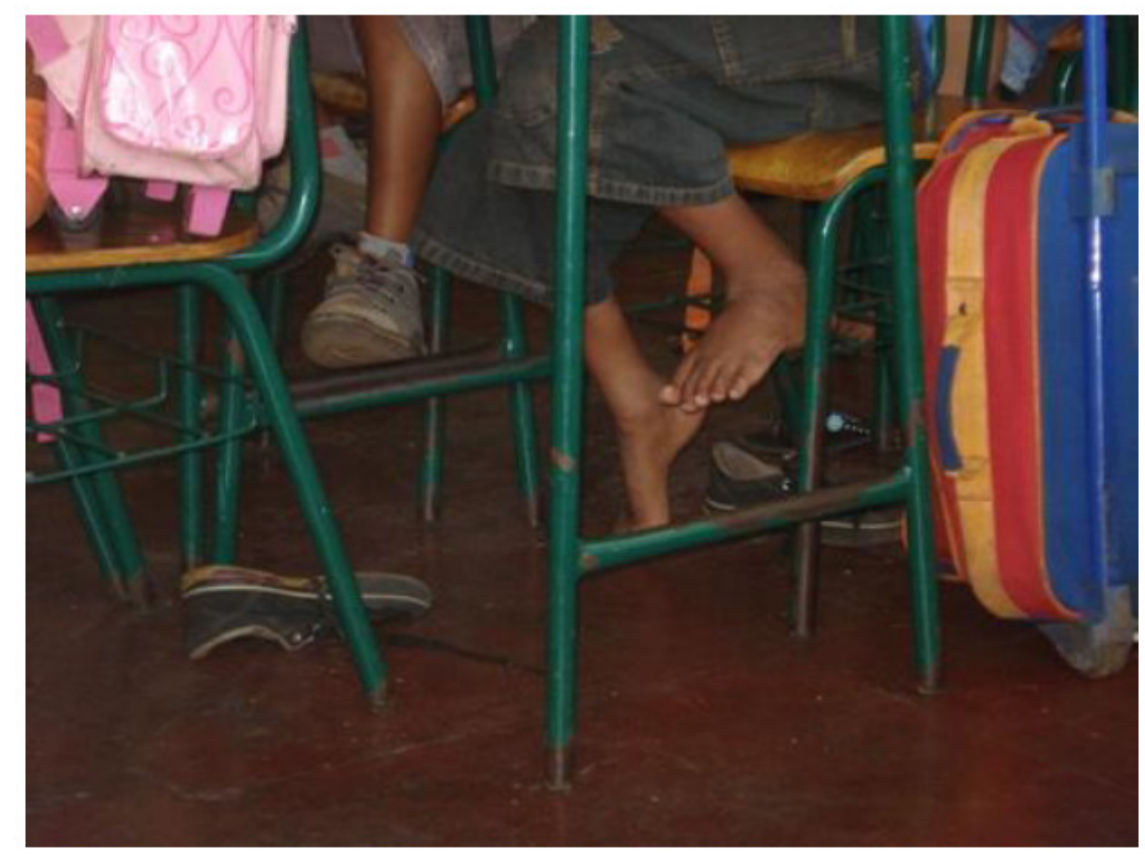

Figura 5. Inadequação do mobiliário para crianças de seis anos: crianças não alcançam o pé no chão e buscam apoio no ferro lateral da cadeira.

Fonte: Costa (2009), p. 107.

Além disso, a autora constatou a necessidade de adequar a altura da lousa nas salas de aula de primeiro ano. Para conseguir escrever na lousa, as crianças precisavam subir em uma cadeira, ou então era necessário que a professora levantasse a criança, como se pode perceber na Figura 6. 


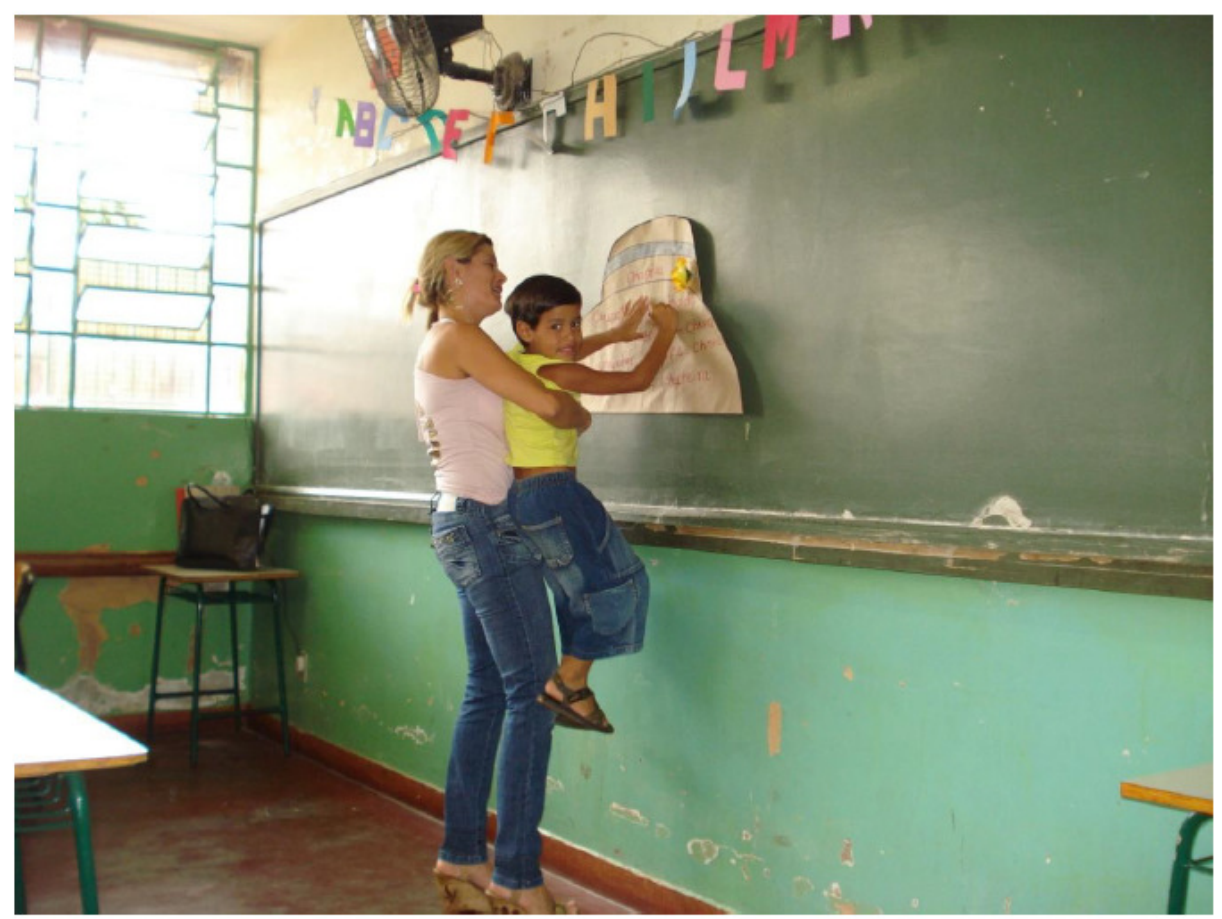

Figura 6. Professora levanta aluno para que ele alcance a lousa.

Fonte: Costa (2009), p. 108.

Ainda, a pesquisadora observou que também era necessária a adequação de sanitários e lavatórios ao tamanho das crianças do Ciclo I, que tinham entre 6 a 8 anos. O diretor da escola em questão reconhecia esta necessidade: "as carteiras são altas pra esses alunos, eu não tenho vaso sanitário para a altura deles, não é adequado ainda” (COSTA, 2009, p. 109).

Analisando o Projeto Político Pedagógico da escola (datado de 2007, mesmo ano de realização da pesquisa), Costa (2009) observou que algumas mudanças estavam previstas, como por exemplo: "aumento do muro, instalação de luminárias no estacionamento, a construção de um pátio interno central coberto, a construção da sala do grêmio estudantil, [...] a construção de 1 sala para guardar os documentos antigos dos alunos" (COSTA, 2009, p. 108), entre outras. No entanto, segundo a pesquisadora, o documento não apontava para a necessidade de mudanças no espaço físico quanto às inadequações apontadas acima, nem a curto ou médio prazo. Vale ressaltar que, conforme informa a autora, "formalmente, a Escola recebe crianças de seis anos desde a implantação do Bloco Único de Alfabetização que passou a vigorar em 1996" (COSTA, 2009, p. 109). Portanto, observa-se que apesar da necessidade de adequações do espaço físico para a inclusão das crianças de seis anos, grande parte dos investimentos seria encaminhada para reformas pouco relevantes para a garantia de qualidade da educação. 
Além disso, a partir da situação evidenciada na Figura 6, é possível problematizar: seria a lousa relevante para o processo ensino-aprendizagem? Mesmo a criança não alcançando a lousa, é feito todo um esforço para que isso ocorra. Observa-se, com isso, que a lousa ainda ocupa espaço de centralidade no ensino, com as carteiras organizadas de frente para ela, e de costas para os demais colegas de sala.

Alguns profissionais, mediante esforço próprio, tentaram realizar algumas mudanças. Este é o caso de uma das professoras entrevistadas por Souza (2012), que criou um ambiente lúdico em sala de aula, como pode ser visto nas imagens abaixo (Figura 7 e Figura 8).

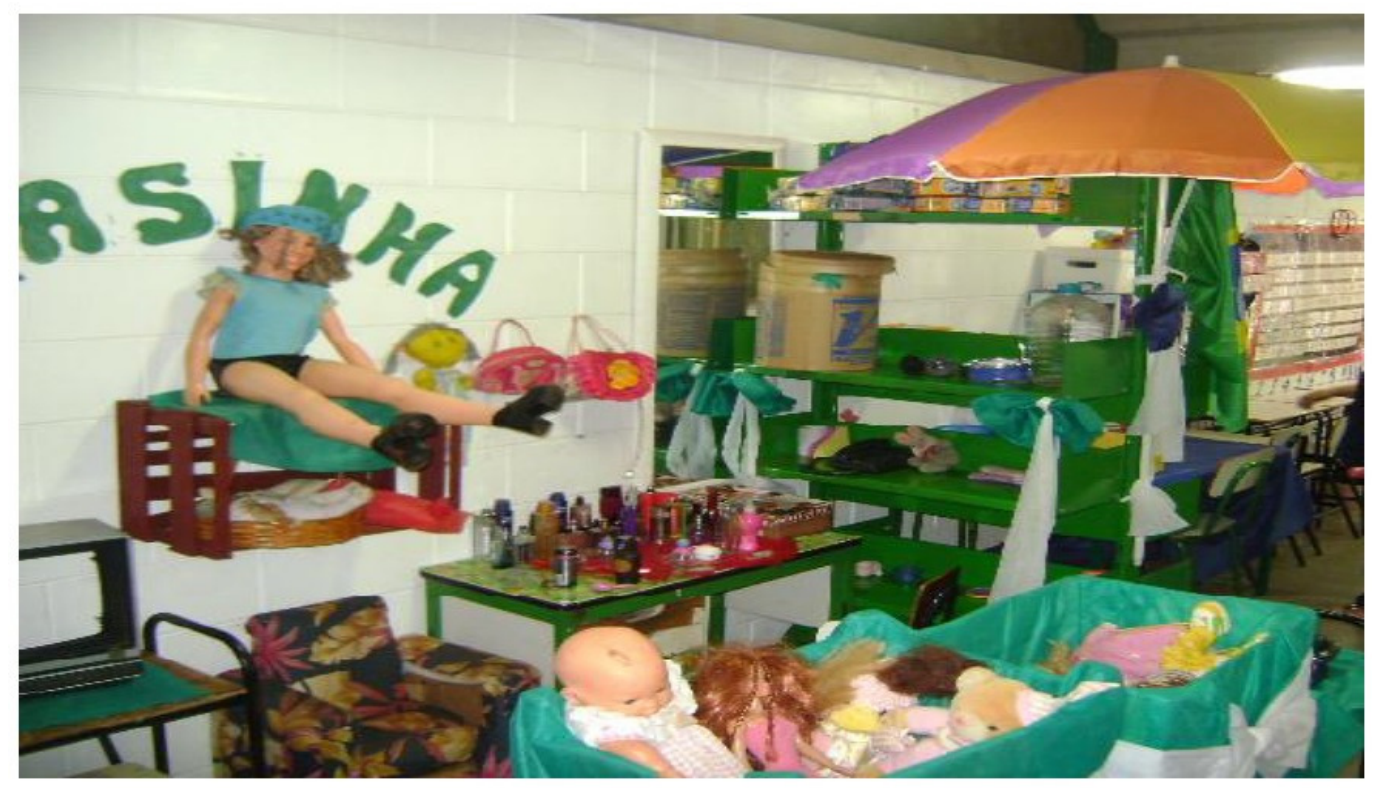

Figura 7. Ambiente lúdico em sala de aula confeccionado pela professora de $1^{\circ}$ ano. Fonte: Souza (2012), p. 91 


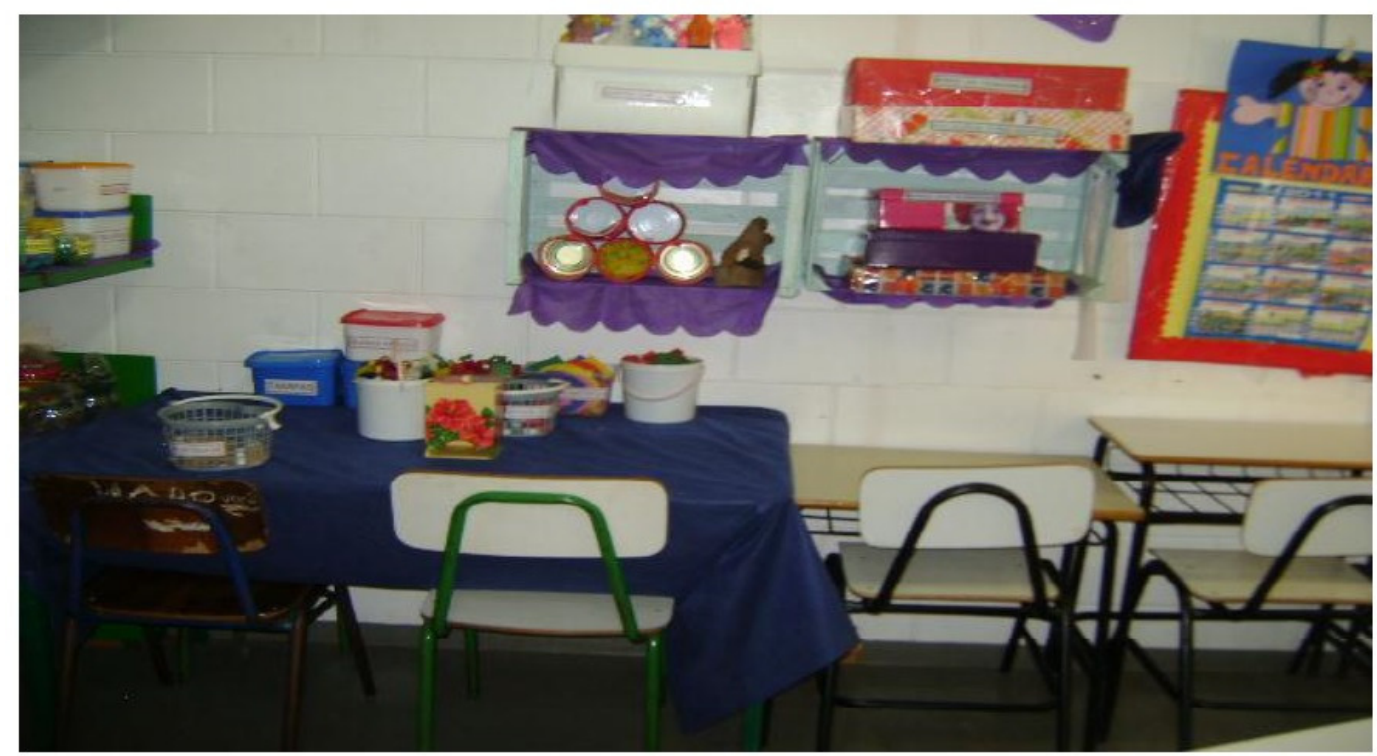

Figura 8. Outros brinquedos confeccionados pela professora de $1^{\circ}$ ano.

Fonte: Souza (2012), p. 92

Nas Figuras 7 e 8 podemos perceber o empenho da professora em propiciar uma sala de aula que se aproxime das necessidades pedagógicas das crianças de seis anos (SOUZA, 2012). Segundo Souza (2012), a professora relatou que todo o material lúdico existente nesse espaço é resultado de confecção própria, por meio de trabalhos com objetos recicláveis e donativos.

Porém, conforme ressalta Souza (2012), “as mudanças na sala de aula do primeiro ano do Ensino Fundamental não se estende para os outros espaços da Escola II, pois se trata de uma iniciativa própria da professora" (p. 90). Nesse sentido, vale ressaltar que as questões de infra-estrutura das escolas são de responsabilidade dos órgãos responsáveis pela gestão educacional, e não do professor. Assim, são necessários investimentos públicos para que sejam feitas todas as mudanças e alterações físicas nas escolas para atender as necessidades das crianças de seis anos.

Abreu (2009), Abreu (2010), Bezerra (2011) e Rocha (2012) observaram em suas pesquisas que nenhuma alteração foi feita quanto à estrutura física da escola. Rocha (2012) teve como objetivo de sua pesquisa de mestrado analisar como a política do ensino fundamental de nove anos vem se instituindo e quais mudanças provocou no cotidiano das escolas das redes municipal e estadual de ensino do Estado de Alagoas, a partir da experiência do município de Delmiro Gouveia. Para isso, a pesquisadora realizou entrevistas com pais e professores em três escolas: duas da rede municipal e uma estadual. Em seu estudo, Rocha 
(2012) observou que houve pouca assessoria dos órgãos públicos, não havendo a aquisição de brinquedos e jogos para emprego do lúdico nas escolas estudadas. A autora afirma que, além da inadequação dos espaços e da falta de material apropriado para o trabalho com as crianças pequenas, foi possível constatar pouco apoio por parte dos órgãos públicos aos docentes, e que este "se resume às orientações pedagógicas nos momentos de departamento (horasatividades), e quase sempre, diz respeito a cobranças por resultados" (ROCHA, 2012, p. 148).

Abreu (2010) buscou ouvir as crianças de $1^{\circ}$ ano de uma escola municipal do interior de Pernambuco, promovendo grupos de conversa com elas durante suas visitas à escola. Com o objetivo de discutir os sentimentos revelados pelas crianças ingressantes no $1^{\mathrm{o}}$ ano do ensino fundamental, a autora foca sua preocupação em analisar as concepções das crianças sobre o que é a escola, e seus sentimentos em relação aos espaços e às vivências na escola. A autora relata que na escola investigada, o espaço físico para brincar era bastante precário: os alunos brincavam num espaço pequeno, externo, sob supervisão de um agente de disciplina. Segundo ela, em dias de chuva, o único espaço possível para as crianças passarem o recreio era o refeitório, como contam as crianças participantes da pesquisa:

Pesquisadora: Quando está chovendo, como é que vocês fazem na hora do recreio?

Tarcísio: A gente só brinca dentro de onde a gente lancha.

Inês: Mas o homem lá não deixa [brincar], porque quebra as mesas, cai... (ABREU, 2010, p. 56).

Conforme afirma a pesquisadora, as crianças demonstraram frustração por não ter espaços para brincar. Apesar da escola investigada por Abreu (2010) contar com um parque infantil, a autora constatou que este não era utilizado pelas crianças porque havia ferrugem nos brinquedos. Além disso, a autora afirma que o espaço oferecia riscos, pois era pequeno e os brinquedos ficavam muito próximos uns dos outros, dificultando a movimentação das crianças e podendo causar acidentes. Por conta da deterioração do parque, as crianças não tinham acesso a ele. Segundo a autora, não foi constatada nenhuma medida para reverter essa situação (ABREU, 2010).

A construção de parques infantis foi a maior dificuldade enfrentada quanto às modificações para inclusão da criança de seis anos para algumas das realidades estudadas pelas pesquisas (COSTA, 2009; SILVA, 2009; ABREU, 2010; SOUZA, 2012;). Cabe comentar, que esses parques já deveriam existir nas escolas que atendem os anos iniciais do ensino fundamental, pois eles são importantes não apenas para as crianças de seis anos. 
Silva (2009), em estudo de grande abrangência, traz resultados interessantes nesse sentido. A pesquisa envolveu questionários enviados à secretarias de educação de nove municípios de Santa Catarina (Joinvile, Palhoça, Indaial, Bom Retiro, Rio fortuna, Santo Amaro da Imperatriz, Tubarão, Blumenau, Florianópolis). Segundo a pesquisadora, analisando as ações que os municípios adotaram para implementar e efetivar condições adequadas ao funcionamento do Ensino Fundamental de nove anos, foi possível perceber que as ações mais utilizadas se referem à adequação de mobiliário, compra de brinquedos e de outros objetos para as classes de seis anos, especificamente. Frente a essa constatação, Silva (2009) atenta para a importância de um olhar cuidadoso das redes municipais para infraestrutura, para que estas mudanças contemplem o lúdico e não se perca as importantes conquistas resultantes de movimentos sociais para melhorar as condições da educação no âmbito da Educação Infantil,

pois intensas foram as mobilizações para um atendimento que respeitasse aos direitos fundamentais das crianças no âmbito da Educação Infantil. Hoje tais direitos e desafios devem ser estendidos para as crianças do Ensino Fundamental, não apenas para aquelas das classes de seis anos (SILVA, 2009, p. 128).

Para a autora, a infraestrutura das escolas e a organização dos espaços e tempos escolares deveriam ter sido contempladas de forma mais intensa no momento da implantação, visto a necessidade das escolas se adequarem à nova proposta de ensino fundamental.

Nesta discussão, vale a pena retomar o estudo de Costa (2009). A pesquisadora afirma que, durante a realização de observações participantes, ouviu as crianças afirmaram por diversas vezes que faltava na escola um parquinho para brincarem, que tivesse balanço e escorregador. Para o diretor da escola, no entanto, colocar parquinho no recreio pode gerar mais problemas:

se eu colocar o brinquedo para eles, eles se machucam. Também, eu não consigo manter isso bem cuidado, principalmente nos finais de semana, onde eu não tenho segurança, então eu tenho problemas com vândalo que vem na escola, então ele destrói, eu conserto, não tem problema toda vez que ele destruir, toda vez eu conserto, mas o duro é que com criança não tem jeito (Entrevista em vídeo com o Diretor em 14-02-08).

Costa (2009) analisa que, pela fala do diretor, dois fatores parecem interferir para que as crianças não tenham o parquinho: (1) a possibilidade das crianças se machucarem e (2) a destruição provocada por "vândalos", denunciando também problemas com a segurança. Segundo a autora, essas são preocupações reais e que demandam um trabalho por parte da 
escola no sentido de orientar os alunos quanto ao uso adequado do parquinho para não se machucarem, ao mesmo tempo que o poder público deve oferecer condições para que a escola não restrinja o atendimento às necessidades das crianças.

A pesquisa de Costa (2009) mostra alguns empecilhos enfrentados pelas escolas na construção do parque infantil, e alerta para que a instalação de um parquinho na escola seja discutida pelo coletivo da escola, ouvindo, inclusive, as crianças.

Em contrapartida, o estudo de Almeida (2011) retrata uma realidade em que houveram iniciativas bem sucedidas em realizar adaptações na escola. Através de observações em três escolas municipais da cidade de São Paulo e questionários com três gestores escolares e três supervisores da Secretaria Municipal de Educação, o autor observou preocupação em realizar as mudanças necessárias. Almeida (2011) constatou a realização de mudanças físicas nas escolas estudadas, como a construção de parques infantis e adequação do mobiliário, com o recebimento de cadeiras e carteiras em tamanhos menores.

Segundo o autor, algumas das adaptações feitas nas escolas resultaram de discussões que envolveram diversos segmentos da escola e comunidade, como é o caso da construção dos parques infantis, enquanto outras foram realizadas de forma centralizada para toda rede, como foi o caso da aquisição de cadeiras e de carteiras em tamanho adequado para as crianças pequenas. A fala seguinte de um gestor escolar esclarece essa situação:

As adequações físicas realizadas foram a construção, por iniciativa da escola, do parque, onde é necessário ressaltar que o uso é para todas as crianças da escola, inclusive as do Ciclo II, e a troca de mesas e cadeiras, por parte de SME (ESCOLA 1).(ALMEIDA, 2011, p. 171).

Assim, este estudo mostra que a decisão de construção do parque foi tomada pelo coletivo de cada escola, recebendo apoio e condições para a construção pela SME. Nesse sentido, Almeida (2011) diz que o esforço para a construção do parque revela as concepções do brincar de cada escola e seu coletivo: "alguns preferiram a construção de um parque em local acessível a todos e com estrutura para suportar a utilização por qualquer aluno da escola; outros preferiram a construção de parque em locais restritos e para uso específicos das crianças pequenas" (p. 171).

Considera-se o estudo de Almeida (2011) bastante relevante para esta discussão, pois dá pistas de que a discussão com todo o coletivo escolar é essencial para que a escola una forças para se mobilizar e conquistar as mudanças necessárias em prol de melhorias na qualidade da educação. 
Moraes (2012) também mostra mobilização para adequação em pesquisa feita com professores e coordenadores de cinco diferentes escolas da rede municipal de São Carlos. Segundo a autora, nas escolas estudadas foram feitas modificações como a construção de parque, aquisição de jogos, aquisição de materiais pedagógicos e carteiras. Uma coordenadora pedagógica afirmou que a construção do parque ocorreu em todas as escolas municipais de educação básica, enquanto outra coordenadora afirmou que a escola já contava com espaço adequado, pois atendia Educação Infantil. Porém, as entrevistadas ofereceram poucas informações a respeito, não sendo possível conhecer quais medidas tomadas contribuíram para que as readequações das escolas fossem bem sucedidas.

Nogueira (2011) também relata mobilização para adequar o espaço físico das escolas. Sua pesquisa, em Pelotas (RS), foi realizada através de observações de uma turma de préescola e uma turma de $1^{\circ}$ ano do fundamental, além de entrevistas com um membro da SME, um coordenador pedagógico, cinco professores, e cinco crianças (em duas entrevistas coletivas) de uma escola da rede municipal. Conforme constatou Nogueira (2011), a escola recebeu da SME mobiliários novos, kits de literatura infantil, jogos pedagógicos, instrumentos musicais.

Entretanto, muitos materiais previstos não chegaram no ano da implantação - 2008 - e outros ainda estavam por chegar em 2010. Ainda em relação a esse aspecto, foi observado que alguns materiais recebidos para o $1^{\circ}$ ano não foram utilizados, como foi o caso dos instrumentos musicais que permaneceram guardados durante todo ano letivo no depósito da escola, e posteriormente acabaram sendo repassados para a turma de pré-escola. A autora ainda relata que a partir das observações no cotidiano das aulas da pré-escola em 2009 e do $1^{\circ}$ ano em 2010, foi possível identificar que, independentemente do mobiliário e dos materiais recebidos, foram as professoras que estabeleceram na prática diária os diferentes modos de utilização dos materiais, característicos de Educação Infantil ou de Ensino Fundamental. Segundo a pesquisadora, exemplo disso é a disposição das mesas na sala de aula do $1^{\circ}$ ano, na maioria das vezes organizadas em fileiras, acarretando poucos momentos em que as crianças trabalharam em grupos ou em duplas.

O estudo de Nogueira (2011) mostra como o incentivo dos órgãos públicos (instância macrossocial ou esfera dos sistemas de ensino) é importante para a mobilização e concretização de adequações do ambiente escolar para a idade de seis anos. Porém, da mesma maneira, mostra como é no âmbito escolar (instância microssocial) que a proposta do ensino fundamental de nove anos se concretiza ou não, ressaltando, novamente, a importância da 
participação ativa do coletivo escolar nas discussões e decisões políticas em educação, em especial os professores, que são os principais atores na implantação do ensino fundamental de nove anos.

Ainda sobre as mudanças na estrutura física da escola, é importante ressaltar que para que o espaço da sala de aula se constitua num espaço de brincar, não são necessários grandes recursos ou materiais, uma vez que, nesta fase, a principal brincadeira das crianças é o faz de conta. Assim, para que o brincar ocorra na escola e em sala de aula, é necessário apenas que sejam criadas oportunidades e momentos para que as crianças brinquem. Além disso, é importante ressaltar que apenas a existência de um parque infantil na escola não garante que este seja utilizado pelas crianças, tampouco garante que o brincar esteja presente na rotina escolar e seja valorizado como forma das crianças se expressarem e aprenderem. A organização do espaço escolar de forma a atender as necessidades da infância vai além da aquisição de novas carteiras ou brinquedos.

A pesquisa realizada por Samways (2012) envolveu observações e entrevistas em uma escola privada e duas escolas municipais de Ponta Grossa (RS), e apresenta fotos dos ambientes observados nestas escolas. O estudo revela que as escolas investigadas já contavam com espaços lúdicos adequados às necessidades das crianças de seis anos (uma vez que atendiam também a educação infantil) tendo necessitado de investimentos quanto ao aumento de salas de aula, professores e funcionários. As fotos a seguir mostram o parque e o pátio das escolas, que já faziam parte de sua estrutura física.

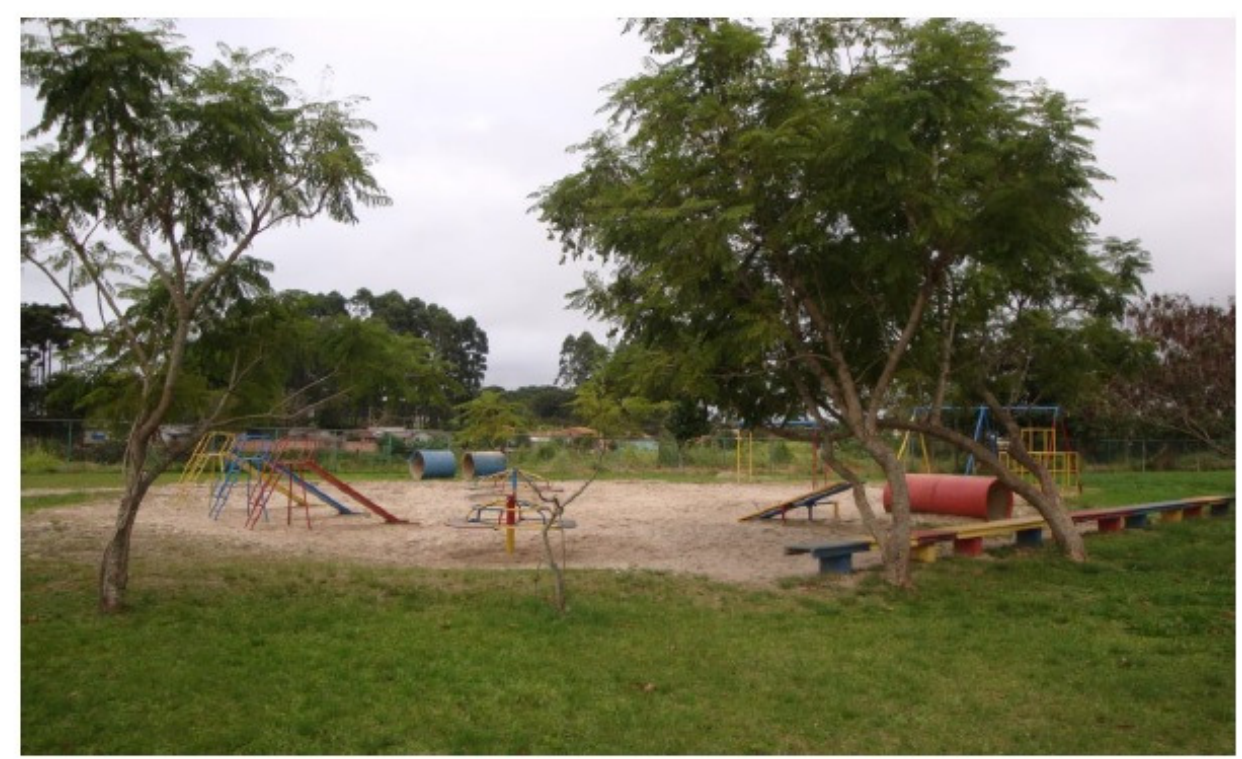

Figura 9. Parque infantil de escola privada que atende Educação Infantil e $1^{\circ}$ ciclo do Fundamental. 


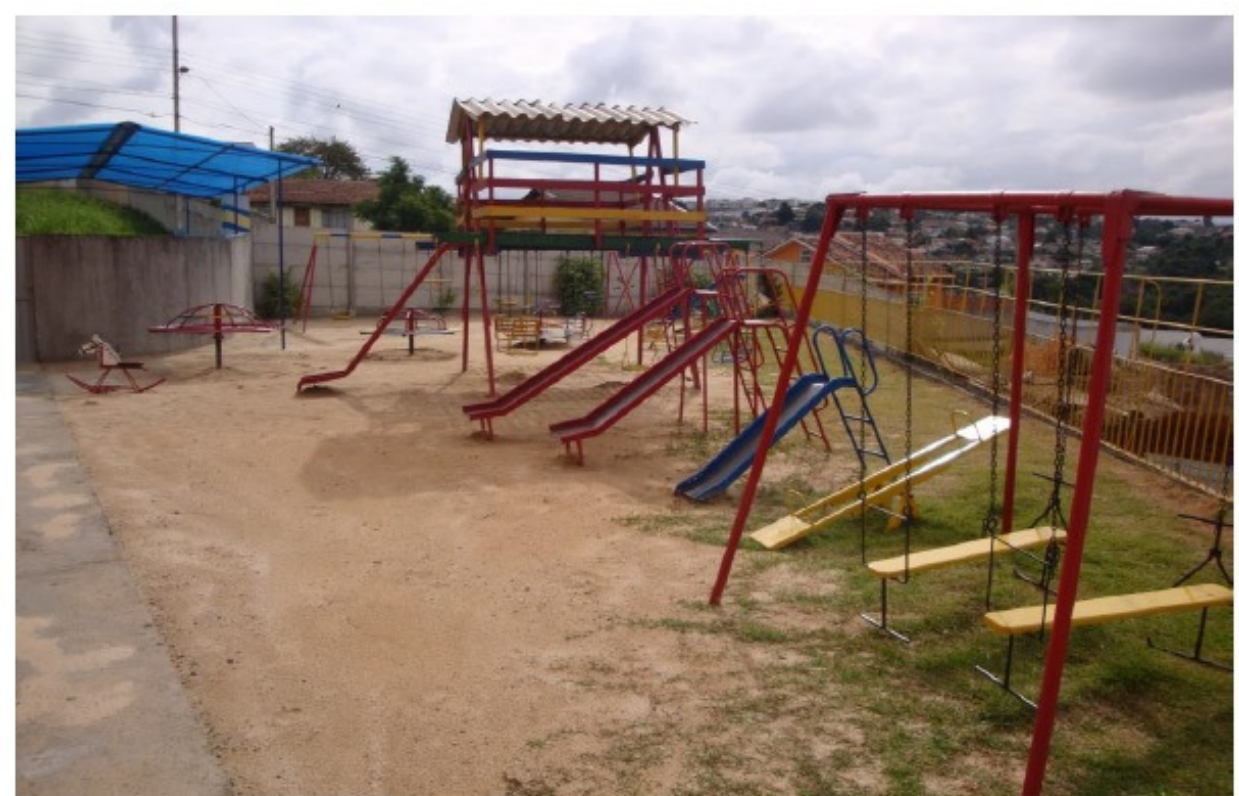

Figura 10. Parque infantil de escola municipal que atende Educação Infantil e $1^{\circ}$ ciclo do Fundamental.

Fonte: Samways (2012), p. 74.

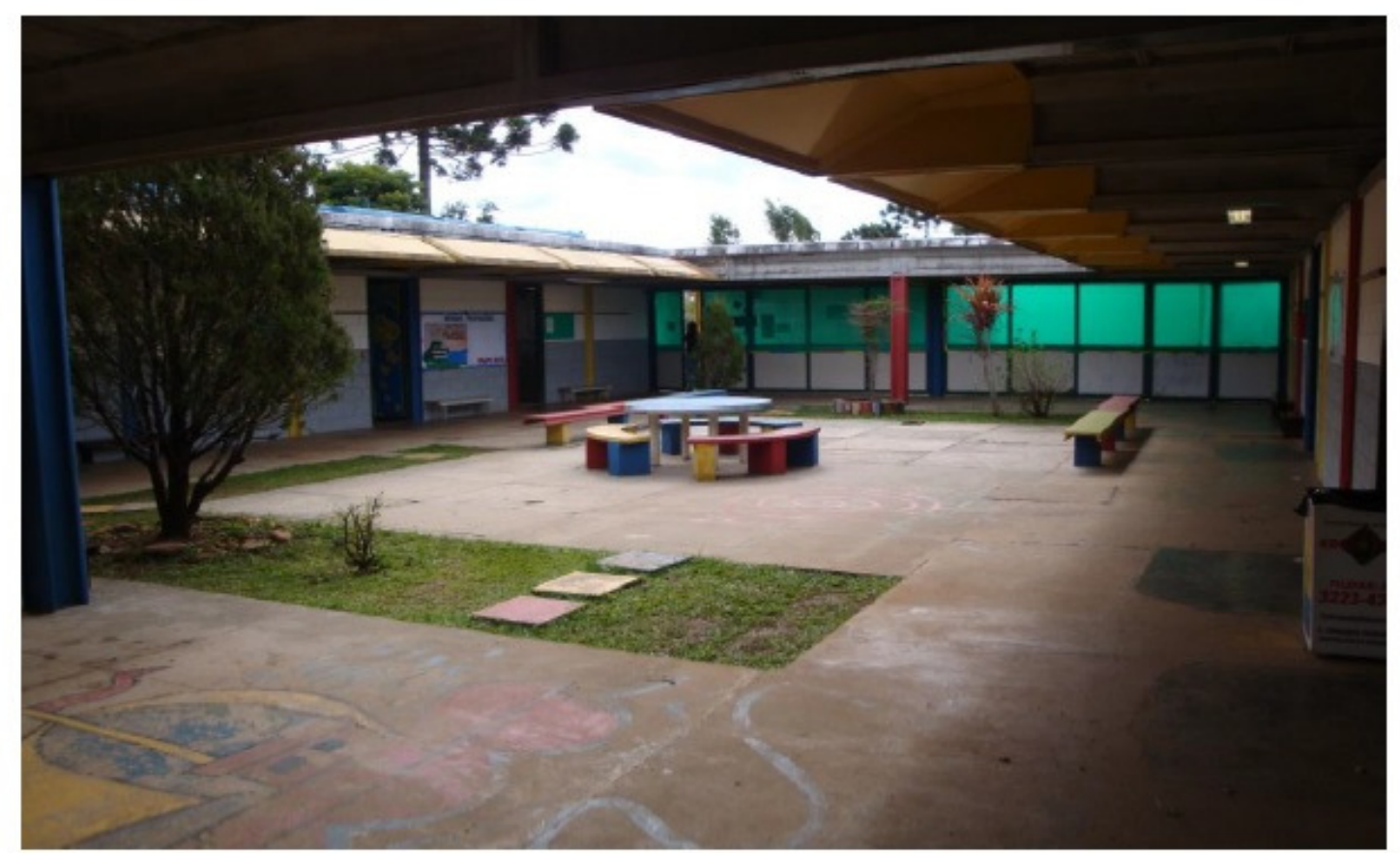

Figura 11. Pátio interno de escola municipal que atende a Educação Infantil e $1^{\circ}$ ciclo do Fundamental.

Fonte: Samways (2012), p. 79 
As Figuras 9, 10 e 11 mostram ambientes lúdicos de escolas que atendem a Educação Infantil, que contam infraestrutura lúdica adequada para atender as necessidades das crianças de seis anos. Estas fotos evidenciam uma realidade bastante diferente das escolas de Ensino Fundamental, que rapidamente tentaram se adequar às necessidades das crianças de seis anos e encontraram muitos empecilhos neste processo, incluindo a construção de parques, como discutimos anteriormente.

Além da estrutura física ser bastante diferente em escolas que já atendiam a Educação Infantil frente às escolas que atendiam apenas o Ensino Fundamental, é possível observar também que a organização da sala de aula também reflete esta diferença dos espaços nas duas etapas de ensino, como se observa nas Figuras 12 e 13:

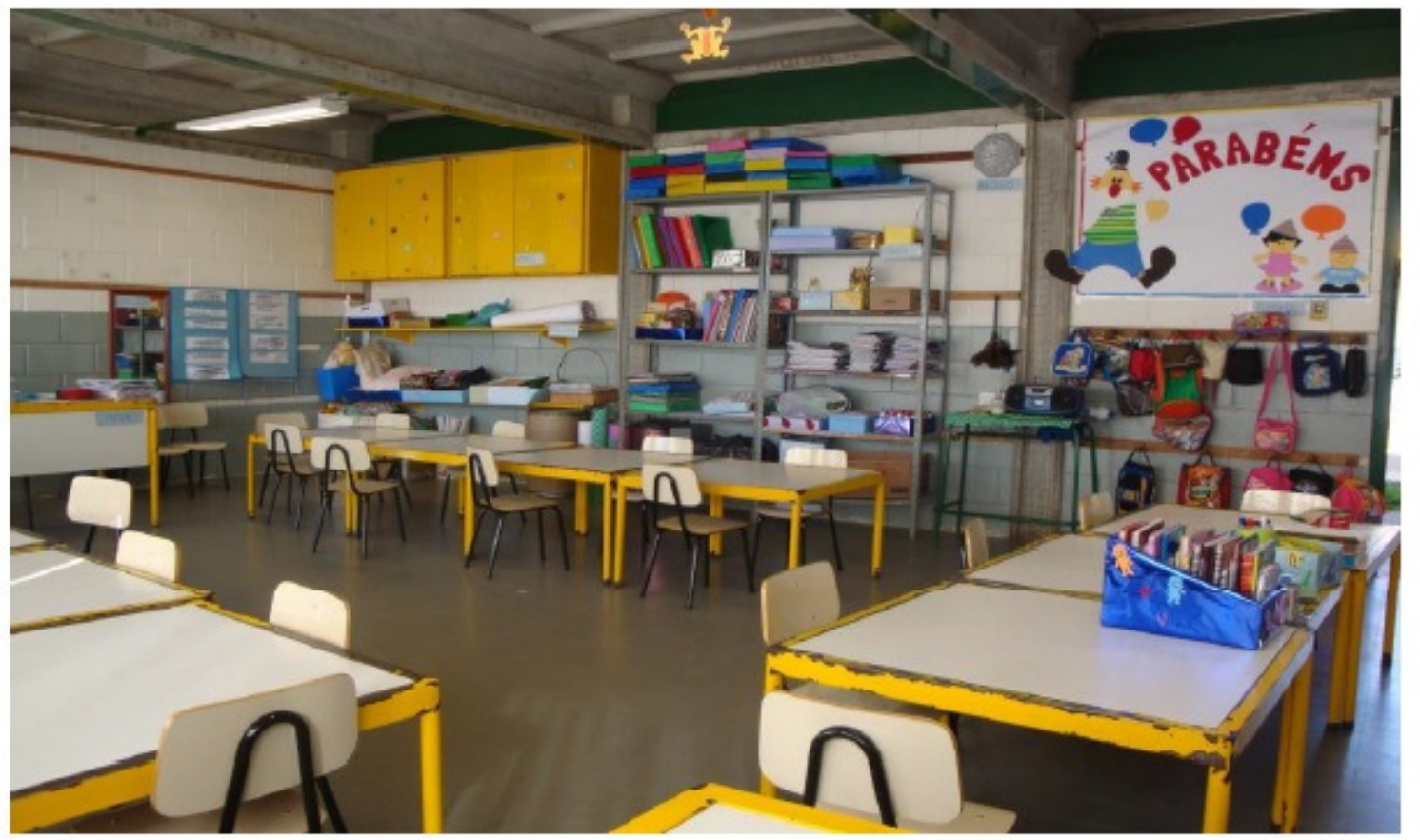

Figura 12. Organização em grupos em uma sala de aula de $1^{\circ}$ ano de escola municipal que atendia Educação Infantil e $1^{\circ}$ ciclo do Fundamental.

Fonte: Samways (2012), p. 77. 


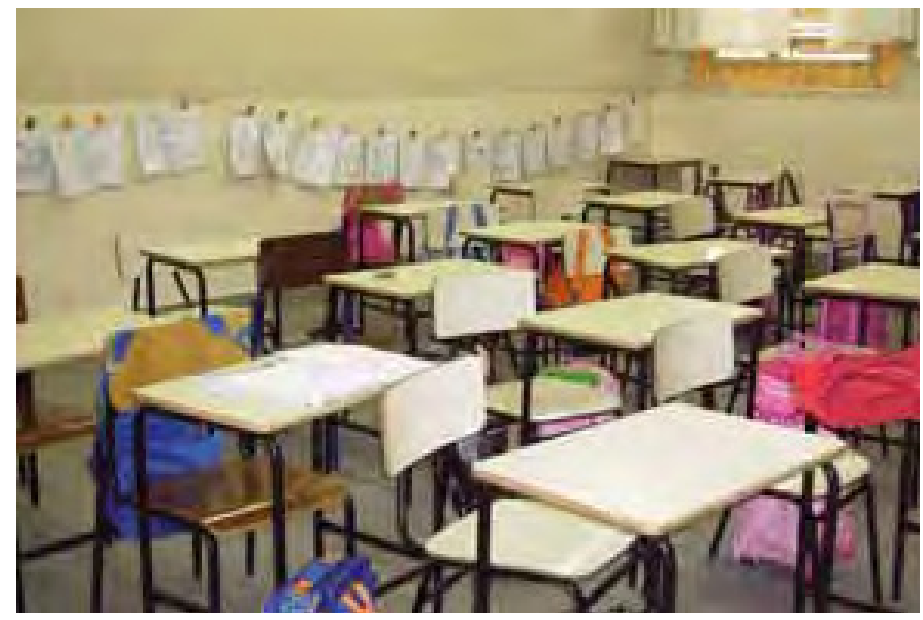

Figura 13. Sala de aula de primeiro ano.

Fonte: Raniro (2009), p. 92.

A sala de aula organizada em pequenos grupos (Figura 12) de duas ou três crianças que fazem suas atividades juntos "favorece interações entre elas e vem ao encontro das discussões atuais sobre a necessidade das crianças estarem juntas, confrontarem conhecimentos, aprenderem em parceria" (AGUIAR, 2012, p. 6). A pesquisa de Aguiar (2012), realizada em uma escola da rede municipal da região Sul do Brasil, é a única a relatar que a SME exigia que as escolas mantivessem essa configuração da sala de aula de $1^{\circ}$ ano do fundamental. Já as demais, quando retratam a realidade observada nas salas de aula, mostram salas com carteiras enfileiradas como ilustra a foto de Raniro (2009) (Figura 13). A pesquisadora também retrata esta realidade com o desenho de uma criança de seis anos sobre sua experiência escolar (Figura 14).
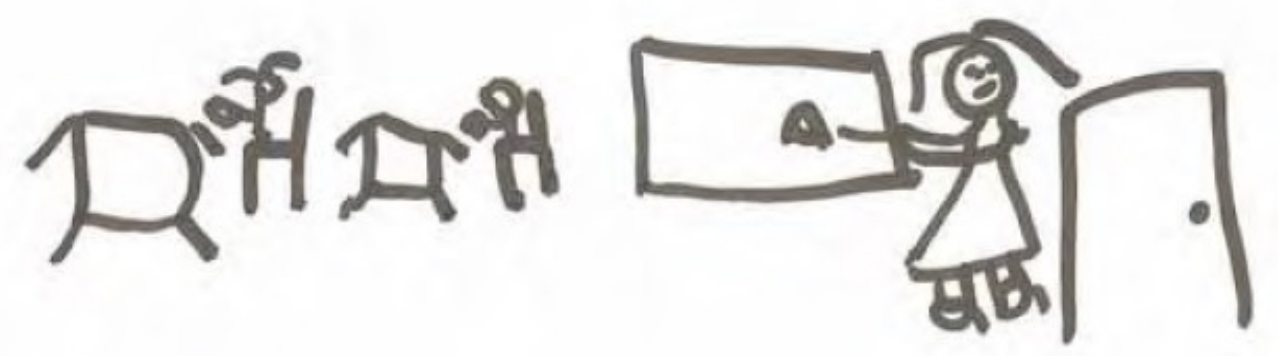

Figura 14. Desenho de criança de seis anos sobre sua experiência escolar. Fonte: Raniro (2009), p. 107. 
O desenho desta criança dispensa maiores explicações. Entende-se que, por si só, ele exprime o que é a vivência escolar para as atuais crianças de seis anos: permanecer sentados nas carteiras, enfileirados, fazendo a lição. Este desenho resume muito do que foi exposto até aqui, e também resultados que ainda serão discutidos, como o lúdico no cotidiano escolar e o currículo do primeiro ano do ensino fundamental.

A partir desses resultados, surge com maior força a inquietação: por que a opção não foi no sentido de tornar obrigatório o último ano da pré-escola? Apesar das escolas de Educação Infantil se mostrarem muito mais adequadas para atender às crianças de seis anos, escolheu-se por inserir as crianças de seis anos na etapa do Ensino Fundamental, deixando a cargo dos municípios onde alocar essas crianças (em escolas de Educação Infantil ou Ensino Fundamental). Considera-se que a pesquisa de Samways (2012) reforça o argumento de que o ensino fundamental de nove anos nasce de um interesse econômico. Como já discutido, a lei foi aprovada ainda no contexto do Fundef, fundo que só atendia o ensino fundamental, portanto o caminho mais fácil para se obter os recursos do Fundef passava pela inclusão dos alunos de seis anos no ensino fundamental.

A importância das mudanças e adequações da escola às necessidades das crianças de seis anos não diz somente ao cumprimento das orientações do MEC, mas sim à garantia dos direitos das crianças de seis anos: "um mínimo de qualidade por meio da garantia de seus direitos básicos" (CORREA, 2007, p. 11). Nesse sentido, como garantir o direito a brincadeira a essas crianças, considerando que nas escolas de Ensino Fundamental são raros os espaços que contemplam parques infantis, brinquedotecas, e em geral faltam materiais didáticos para as crianças pequenas? Correa (2007) questiona:

Considerando o já exposto quanto à estrutura e organização da maioria de nossas escolas de Ensino Fundamental, fica-nos a questão: em que medida esta escola conseguirá efetivar o direito à expressão, à aprendizagem e ao desenvolvimento por meio de múltiplas experiências? Crianças submetidas a quatro horas diárias de aula sentadas, apenas ouvindo a exposição de um professor, copiando "matéria" da lousa ou fazendo "exercícios" de repetição certamente não terão condições de alcançar um desenvolvimento satisfatório, menos ainda, integral (CORREA, 2007, p. 12)."

O documento "Ensino fundamental de nove anos: orientações para a inclusão da criança de seis anos de idade" (BRASIL, 2007c) explicita que os espaços educativos, os materiais didáticos, o mobiliário e os equipamentos precisam ser repensados para atender às crianças com essa nova faixa etária no ensino fundamental, bem como às crianças que já 
estavam nessa etapa de ensino com oito anos de duração (BRASIL, 2007c). No entanto, concorda-se com Costa (2009) de que este discurso não alerta os profissionais da educação da real importância destas modificações e adequações físicas, sem enfatizar que se trata de garantir os direitos das crianças.

\footnotetext{
Embora o documento aponte para a necessidade de adequação dos materiais, mobiliários e equipamentos às necessidades e condições físicas da criança, ele o indica como medida a ser repensada, discurso que ameniza a urgência dessa mudança, que deveria ser uma das medidas condicionantes para a realização do trabalho com as crianças entre seis a oito anos (COSTA, 2009, p. 111, grifo nosso).
}

Da mesma forma, se a intenção em inserir as crianças de seis anos no ensino fundamental era promover mudanças nessa etapa de ensino de forma a se tornar mais lúdica, deveria estar mais explícito nos documentos a importância do parque infantil e do acesso deste às demais crianças do fundamental, que não apenas as do $1^{\circ}$ ano. Como já comentado anteriormente, com base em Almeida (2011), a decisão sobre quem teria acesso ao parque ficou a cargo das escolas, e estas, por entender que a necessidade surge com o ingresso da criança de seis anos no fundamental, muitas vezes restringem o acesso ao parque a elas. Com isso, pouco se vê a preocupação quanto ao acesso a espaços lúdicos para as demais crianças do Ensino Fundamental, o que poderia ser um dos benefícios da lei aprovada. Também para a Educação Infantil pouca atenção foi dada, não havendo nenhuma alteração ou adequação dos espaços (CORREA, 2011).

\subsection{O referencial curricular do $1^{\circ}$ ano: conteúdos e práticas desenvolvidas com as crianças de seis anos.}

Neste tópico, visou-se apresentar os achados das pesquisas que compõem esta revisão acerca do novo currículo do ensino fundamental de nove anos, problematizando as questões decorridas da ampliação no que diz respeito à elaboração de um novo currículo, às práticas pedagógicas e aos conflitos vivenciados pelos professores neste contexto. Assim, buscou-se trazer à discussão os principais resultados das pesquisas analisadas, bem como os resultados que se destacaram de alguma forma das demais produções. 
Para tal, o presente tópico foi organizado de forma a contemplar todas as questões emergentes do material analisado, apresentados em subtópicos. Em um primeiro momento, será apresentado e discutido o que as pesquisas mostram sobre o currículo e as práticas pedagógicas que têm sido adotadas pelos docentes, escolas e municípios desde a ampliação do ensino fundamental para nove anos - questões que emergiram como principais no tratamento dos dados das pesquisas. O material analisado revela ainda outras importantes considerações sobre o currículo no ensino fundamental de nove anos: as contradições entre as orientações e a prática, os efeitos sobre as práticas educacionais na Educação Infantil, e a construção democrática de novo currículo como possibilidade de melhorias na educação - essas questões serão abordadas, na sequência, em diferentes subtópicos. Finalizando o tópico, serão apresentados e discutidos os resultados das pesquisas sobre as formas avaliativas desenvolvidas no primeiro ano.

\subsubsection{Estrutura curricular do primeiro ano do fundamental de nove anos: uma questão de} novas nomenclaturas.

Como discutido no Capítulo II, o Ministério da Educação traz algumas orientações sobre o trabalho a ser desenvolvido no primeiro ano do ensino fundamental, afirmando que "a ampliação do ensino fundamental para nove anos significa, também, uma possibilidade de qualificação do ensino e da aprendizagem da alfabetização e do letramento, pois a criança terá mais tempo para se apropriar desses conteúdos" (BRASIL, 2007c, p. 8). Dessa forma, o Ministério da Educação orienta para que a alfabetização seja iniciada no $1^{\circ}$ ano do ensino fundamental de nove anos, devendo ocorrer ao longo dos dois primeiros anos do ensino fundamental (BRASIL, 2009a).

Nos documentos oficiais "Ensino fundamental de nove anos: orientações gerais" (BRASIL, 2004a) e "Ensino fundamental de nove anos: orientações para a inclusão da criança de seis anos de idade" (BRASIL, 2007c), foi ressaltado que o ensino no primeiro ano não deve se reduzir à alfabetização, reafirmando "a importância de um trabalho pedagógico que assegure o estudo das diversas expressões e de todas as áreas do conhecimento, igualmente necessárias à formação do estudante do ensino fundamental" (BRASIL, 2007c, p. 8). Além disso, o Ministério da Educação pontua que o ensino fundamental de nove anos se constitui como oportunidade para modificar o currículo de todo o ensino fundamental em 
busca da almejada educação democrática, sugerindo que a reformulação do currículo não se restrinja aos primeiros anos do ensino fundamental, como se observa na citação a seguir:

[...] é importante salientar que a mudança na estrutura do ensino fundamental não deve se restringir a o que fazer exclusivamente nos primeiros anos: este é o momento para repensar todo o ensino fundamental - tanto os cinco anos iniciais quanto os quatro anos finais. [...] lembramos que os sistemas, neste momento, terão a oportunidade de rever currículos, conteúdos e práticas pedagógicas não somente para o primeiro ano, mas para todo o ensino fundamental (BRASIL, 2007c, p. 8).

Com relação ao referencial curricular e aos conteúdos ministrados no primeiro ano do ensino fundamental de nove anos, a maioria dos trabalhos analisados nesta revisão bibliográfica aponta para a ênfase dada à alfabetização, manutenção de práticas pedagógicas realizadas na antiga $1^{\mathrm{a}}$ série e alterações pouco significativas no currículo do $1^{\mathrm{o}}$ ano (ABDIAN e CIARDELLA, 2011; ABREU, 2009; ABREU, 2010; ALMEIDA, 2011; ALMEIDA, 2012; AMARAL, 2008; ANTUNES, 2010; ARAÚJO, 2008; ARELARO, JACOMINI e KLEIN, 2011; BARBOSA, 2009; BEZERRA, 2011; BONAMIGO, 2010; BRANDÃO, 2012; BUENO, 2010; CAPUCHINHO, 2007; CARNEIRO, 2006; CHAVES, 20012; CORREA, 2010; CORREA, 2011; COSTA, 2009; DANTAS, 2009; DELFIN, 2012; FONTES, 2009; FURTADO, 2009; GIL, 2012; HASHIMOTO, 2012; JACOMINI, ROSA e ALENCAR, 2012; KLEIN, 2011; LENCIONI, 2011; LIMA, 2011; MALTA, 2012; MARCONDES, 2012; MASCIOLI, 2012; MIRANDA, 2012; MORO, 2009; NOGUEIRA e CATANANTE, 2011; NOGUEIRA, 2011; OLIVEIRA, 2011; PANSINI e MARIN, 2011; PORTELLA e HICKEL, 2010; PURIM, 2010; RANIRO, 2009; ROCHA, 2012; SILVA e SCAFF, 2009; SILVA, 2008; SILVA, 2009; SOUZA, 2012; STURION, 2010; TASCA, 2010; TOSCANO e SAITO, 2009). A seguir, serão apresentadas algumas pesquisas que relatam estes dados e discutidos os seus resultados.

Arelaro, Jacomini e Klein (2011) indicam em seu estudo que nenhuma alteração significativa foi feita no currículo e tampouco no trabalho pedagógico nas redes municipais de Suzano (SP) e estaduais de São Paulo (SP). A partir das entrevistas e questionários com professores e gestores, as autoras constataram que o currículo do primeiro ano do ensino fundamental refletia uma adaptação simplista do antigo currículo da primeira série, contando apenas com pequenas adequações metodológicas para garantir momentos de brincadeiras. Uma das professoras entrevistadas, ao ser questionada se foram realizadas adaptações no 
currículo para trabalhar com as crianças de seis anos, responde negativamente, e acrescenta: "nos últimos anos há uma preocupação maior com deixá-los um pouco mais livres pra brincar, mas também não pode ser muito porque nós temos metas pra atingir. Na essência, o trabalho é o mesmo" (ARELARO, JACOMINI e KLEIN, 2011, p. 47).

Correa (2010) relata resultados semelhantes quanto ao currículo do primeiro ano. Sua pesquisa, desenvolvida em município do interior paulista, foi realizada por meio de análise documental federal e local, e de observações e entrevistas com professores e profissionais da Secretaria Municipal de Educação. Esta análise permitiu que a autora contatasse que o currículo elaborado para o $1^{\circ}$ ano era, em sua essência, igual ao da antiga $1^{\mathrm{a}}$ série, no qual o brincar não ocupou lugar de destaque. O Referencial Curricular elaborado na rede municipal para a implantação do ensino fundamental de nove anos foi organizado em "áreas" do conhecimento, a saber: língua e linguagem; raciocínio lógico-matemático; sócio-histórica e cultural; natureza, ambiente e próprio corpo; arte e movimento. O Quadro 8, elaborado por Correa (2010), mostra a estrutura curricular organizada para o ensino fundamental de nove anos, comparada à estrutura curricular adotada antes da ampliação do ensino fundamental.

Quadro 8: Estrutura Curricular da $1^{\mathrm{a}}$ série do ensino fundamental de oito anos e do $1^{\circ}$ ano do ensino fundamental de nove anos.

\begin{tabular}{|c|c|c|c|}
\hline $\begin{array}{l}\text { Estrutura curricular } \\
\text { EF de oito anos (até } \\
\text { 2006) }\end{array}$ & $\begin{array}{c}\text { Estrutura curricular } \\
\text { EF de nove anos (a partir de 2007) }\end{array}$ & $\begin{array}{c}\text { Aulas } \\
\text { semanais } \\
1^{a} \text { série }\end{array}$ & $\begin{array}{c}\text { Aulas } \\
\text { semanais } \\
1^{\circ} \text { ano }\end{array}$ \\
\hline Língua portuguesa & Língua e linguagem & 7 & 7 \\
\hline Matemática & Raciocínio lógico matemático & 7 & 7 \\
\hline $\begin{array}{l}\text { Ciências físicas e } \\
\text { biológicas }\end{array}$ & Natureza, ambiente e o próprio corpo & 2 & 2 \\
\hline História & \multirow[t]{2}{*}{ Sócio-histórica e cultural } & 2 & \multirow[b]{2}{*}{4} \\
\hline Geografia & & 2 & \\
\hline Arte & \multirow[t]{2}{*}{ Arte e movimento } & 2 & \multirow[b]{2}{*}{5} \\
\hline Educação Física & & 3 & \\
\hline
\end{tabular}

Fonte: Correa (2010), p. 9.

Ao observar as nomenclaturas e analisar a carga horária de cada uma dessas áreas, é possível concluir que de fato nenhuma alteração foi feita, se tratando apenas de novos nomes para algo que já existia. Além disso, é possível constatar uma predominância de conteúdos relacionados à alfabetização e à matemática (CORREA, 2010). Segundo Correa (2010), os 
dados encontrados no Quadro 8 foram retirados do Projeto Pedagógico da escola em que se realizou a pesquisa. Em entrevistas com os coordenadores da escola, estes afirmaram que o projeto segue as orientações da Secretaria Municipal de Educação, permitindo afirmar que o seu conteúdo expressa a realidade de toda a rede municipal da cidade investigada por Correa (2010).

Souza (2012) também buscou analisar a estrutura curricular adotada em duas escolas municipais de Dourados (MS) investigadas em sua pesquisa. Por meio de análise do Projeto Político Pedagógico, constatou no currículo do $1^{\mathrm{o}}$ ano a predominância do ensino da língua portuguesa, correspondendo à maior parte da carga horária no $1^{\circ}$ e $2^{\circ}$ ano. A Tabela 7 mostra a estrutura curricular e o número de aulas destinadas ao ensino de cada área do $1^{\circ}$ ao $5^{\circ}$ anos do ensino fundamental.

Tabela 7. Matriz curricular do $1^{\circ}$ ao $5^{\circ}$ ano do ensino fundamental.

\begin{tabular}{|l|c|c|c|c|c|}
\hline ESTRUTURA CURRICULAR & \multicolumn{5}{|c|}{ ANO E NÚMERO DE AULAS } \\
\hline LÍNGUA PORTUGUESA & $1^{\circ}$ & $2^{\circ}$ & $3^{\circ}$ & $4^{\circ}$ & $5^{\circ}$ \\
\hline MATEMÁTICA & 06 & 06 & 05 & 05 & 05 \\
\hline CIÊNCIAS & 04 & 04 & 05 & 05 & 05 \\
\hline GEOGRAFIA & 02 & 02 & 02 & 02 & 02 \\
\hline HISTÓRIA & 02 & 02 & 02 & 02 & 02 \\
\hline ARTES & 02 & 02 & 02 & 02 & 02 \\
\hline EDUCAÇÃO FÍSICA & 02 & 02 & 02 & 02 & 02 \\
\hline TOTAL - CARGA HORÁRIA & 20 & 20 & 20 & 20 & 20 \\
\hline SEMANAL & & & & & 02 \\
\hline CARGA HORÁRIA ANUAL & 800 & 800 & 800 & 800 & 800 \\
\hline
\end{tabular}

Fonte: Souza (2012), p. 111.

A partir desta tabela é possível observar uma grande semelhança da grade curricular do $1^{\mathrm{o}}$ ano para os demais anos do ensino fundamental, mudando apenas uma aula a mais de língua portuguesa e uma aula a menos de matemática. Ademais, observa-se que das 20 
horas/aula, 10 estão direcionadas ao ensino de Português e Matemática, enquanto as outras 10 estão divididas igualmente entre outras cinco áreas do conhecimento: Ciências, Geografia, História, Artes e Educação Física.

Oliveira (2011) teve como foco em seu estudo analisar a formação continuada e o trabalho pedagógico realizados por professores de $1^{\mathrm{o}}$ ano da rede municipal na cidade de Marília (SP). Sua pesquisa contou com a aplicação de questionários com 47 professores de $1^{\circ}$ ano e 9 coordenadores pedagógicos, além de entrevistas com quatro professores e um gestor da Secretaria Municipal de Educação. Ao discutir seus achados sobre trabalho pedagógico no $1^{\circ}$ ano, Oliveira (2011) mostra ter observado ênfase na alfabetização em detrimento do ensino dos demais conhecimentos: "as professoras têm como preocupação principal o desenvolvimento da criança em relação à linguagem escrita” (p. 91). Além disso, a autora mostra que, na visão das professoras, o ensino da leitura é uma forma de "instrumentalizar" as crianças para o ensino das demais áreas do conhecimento, como pode se observar na fala da professora a seguir:

No primeiro ano a gente visa à alfabetização. Então nosso objetivo final é a alfabetização. Acho que se a criança sair do primeiro ano sabendo, tendo a noção de matemática, de história, de geografia, mas saindo alfabetizada, sabendo bem, ela vai. Priorizo a alfabetização porque a criança sabendo ler e interpretar aquilo que ela está lendo, consigo desenvolver outras áreas. Como a criança irá fazer uma situação-problema se ela não sabe ler? Como ensinar para criança história e geografia se ela não souber ler? (OLIVEIRA, 2011, p. 89).

Segundo a autora, a análise dos dados permite inferir que as professoras não percebem a importância das outras áreas do conhecimento para o desenvolvimento da criança na linguagem escrita com sentido. Oliveira (2011) infere a partir de seus resultados, que as professoras parecem compreender que nas outras formas de expressão não existe um conteúdo.

Para a autora, colabora para o predomínio do ensino da linguagem escrita, em detrimento do ensino das demais áreas do conhecimento, o fato de o próprio professor "se sentir realizado" (p. 91) em seu trabalho de alfabetização. O depoimento de uma docente de primeiro ano mostra com clareza sua satisfação em ver os alunos alfabetizados:

Minha prioridade no trabalho é a alfabetização pelo prazer de ver as crianças lendo e escrevendo. Eu me sinto uma pecadora por não oferecer mais atividades que desenvolvam raciocínio lógico das crianças. Eu me dedico 
demais à alfabetização. Você já percebeu que eu só falo de alfabetização, alfabetização (risos). Mas eu sei que eu erro muito nessa parte, que eles precisam. Este ano estou tentando me policiar mais. Fico feliz a cada criança que alfabetizo, um sentimento inexplicável, como se fosse a primeira vez, como se fosse o meu filho, é uma sensação de realização, de que estou contribuindo para com a vida da criança, preparando-o para a vida, é maravilhoso, não tenho palavras (OLIVEIRA, 2011, p. 91).

Segundo Oliveira (2011), a fala das docentes indica que o ato de "alfabetizar" parece conceder a elas a oportunidade de alcance da essência de seu ofício, "provavelmente por ser nessa linguagem que percebe concretamente documentada a evolução da criança. Também por ser a linguagem, historicamente, reconhecida como função da escola ensinar" (p. 92). A priorização da alfabetização revela que há uma tendência de se colocar em primeiro plano a garantia de aprendizagem de determinados conteúdos, em geral os culturalmente mais valorizados (lógico-matemáticos, letramento, etc.) e, portanto, mais solicitados em avaliações tanto nacionais, quanto estaduais e municipais (OLIVEIRA, 2011).

Sobre o ensino das demais áreas do conhecimento, Raniro (2009) mostra que, apesar delas estarem contempladas no currículo, na prática aparecem em segundo plano. Sua pesquisa, realizada em uma escola de ensino fundamental da rede municipal de São Carlos (SP), envolveu entrevistas com três professoras de $1^{\circ}$ ano, 15 alunos de $1^{\circ}$ ano, e 15 pais/familiares destes alunos, além de observações em sala de aula. Ao analisar como ocorria o ensino de conteúdos de ciências, história e geografia na escola acompanhada, a autora constatou que estas ficavam em segundo plano em relação à alfabetização. Sobre isso a autora pondera:

Outras disciplinas como ciências, história, geografia, são contempladas também, mas já não são tão comuns às práticas das professoras. Estas trabalham com transportes, por exemplo, mas com a finalidade de que as crianças escrevam carro, ou ônibus. Essas disciplinas acabam aparecendo como aliadas à alfabetização ou alternativa para datas cívicas, campanhas de saúde (RANIRO, 2009, p. 119).

Com isso, observa-se que, mesmo nas aulas de ciências, história e geografia, o foco era a alfabetização das crianças (RANIRO, 2009). Como mostram os demais estudos, o que se observa na prática é a ausência de alterações significativas no currículo e ênfase na alfabetização em detrimento do ensino das demais áreas do conhecimento. 
3.3.2 Trabalho docente com as crianças de seis anos: falta de orientações e manutenção de práticas pedagógicas da antiga $1^{a}$ série.

Estes dados das pesquisas aqui resgatados assinalam que a reorganização do currículo, sugerida nos documentos oficiais do Ministério da Educação, não ocorreu na prática. Os estudos apontam ainda para a falta de orientações sobre o trabalho no $1^{\circ}$ ano, e insegurança dos professores quanto ao que deveria ser ensinado, e como ensinar (ALMEIDA, 2011; BEZERRA, 2011; BONAMIGO, 2010; CORREA, 2010; DANTAS, 2009; GORNI, 2007; HASHIMOTO, 2012; KLEIN, 2011; MIRANDA 2012; MORO, 2009; MOYA, 2009; NOGUEIRA e CATANANTE，2011; PANSINI e MARIN，2011; SAMWAYS，2012; SANT'ANNA e GUZZO, 2009; SILVA e SCAFF, 2009; THOMÉ, 2011; TOSCANO e SAITO, 2009; VARGAS, 2010).

O estudo de Thomé (2011) exemplifica esta situação, relatada de forma semelhante nos demais estudos. Sua pesquisa buscou investigar as dificuldades enfrentadas e aprendizados construídos por gestores e professores no ano de implantação do ensino fundamental de nove anos em um município do interior de São Paulo. Por meio de entrevista com a supervisora da Secretaria Municipal de educação e entrevistas com uma coordenadora pedagógica e uma professora de três diferentes escolas municipais, a pesquisadora constatou como principal dificuldade enfrentada a falta de orientações e insegurança das professoras quanto ao trabalho com o $1^{\circ}$ ano. A fala da supervisora evidencia esta dificuldade, observada também no discurso das professoras:

[...] a maior dificuldade está sendo no pedagógico, é, por exemplo: a, eu sei que a criança tem que brincar, mas quantas horas essa criança tem que brincar na semana? Eu sei que a brincadeira tem que ser direcionada, mas como é essa brincadeira direcionada? (THOMÉ, 2011, p. 62).

Estes dados enunciados pelas pesquisas ressaltam que as orientações do Ministério da Educação, a formação ofertada nos municípios e os espaços de discussões propiciados (quando existentes) foram insuficientes para sanar as dúvidas e preparar os profissionais para cumprir com as mudanças prenunciadas pelos documentos oficiais do ensino fundamental de nove anos.

Os estudos mostram que, diante da falta de orientações sobre a ação docente no ensino fundamental de nove anos, observam-se poucas alterações também no trabalho pedagógico 
desenvolvido pelos docentes de primeiro ano. Conforme foi afirmado no início deste tópico, grande parte das pesquisas analisadas indica a manutenção de práticas pedagógicas da antiga $1^{\mathrm{a}}$ série no primeiro ano do ensino fundamental de nove anos.

Costa (2009) realizou uma pesquisa na rede municipal de Goiânia através de observação participante de uma turma de primeiro ano de uma escola da rede municipal. Seu estudo buscou compreender o lugar que a criança de seis anos ocupa no contexto do ensino fundamental de nove anos. Através das observações a autora voltou sua atenção para as crianças, suas falas, e suas vivências.

A pesquisadora constatou a prevalência de atividades relacionadas à alfabetização, muito semelhantes às atividades pedagógicas utilizadas na antiga $1^{\mathrm{a}}$ série. A autora ilustra esta realidade, apresentando uma foto (Figura 15), registrada pela autora, do caderno de uma aluna, onde se vê uma atividade de caligrafia passada às crianças de seis anos.

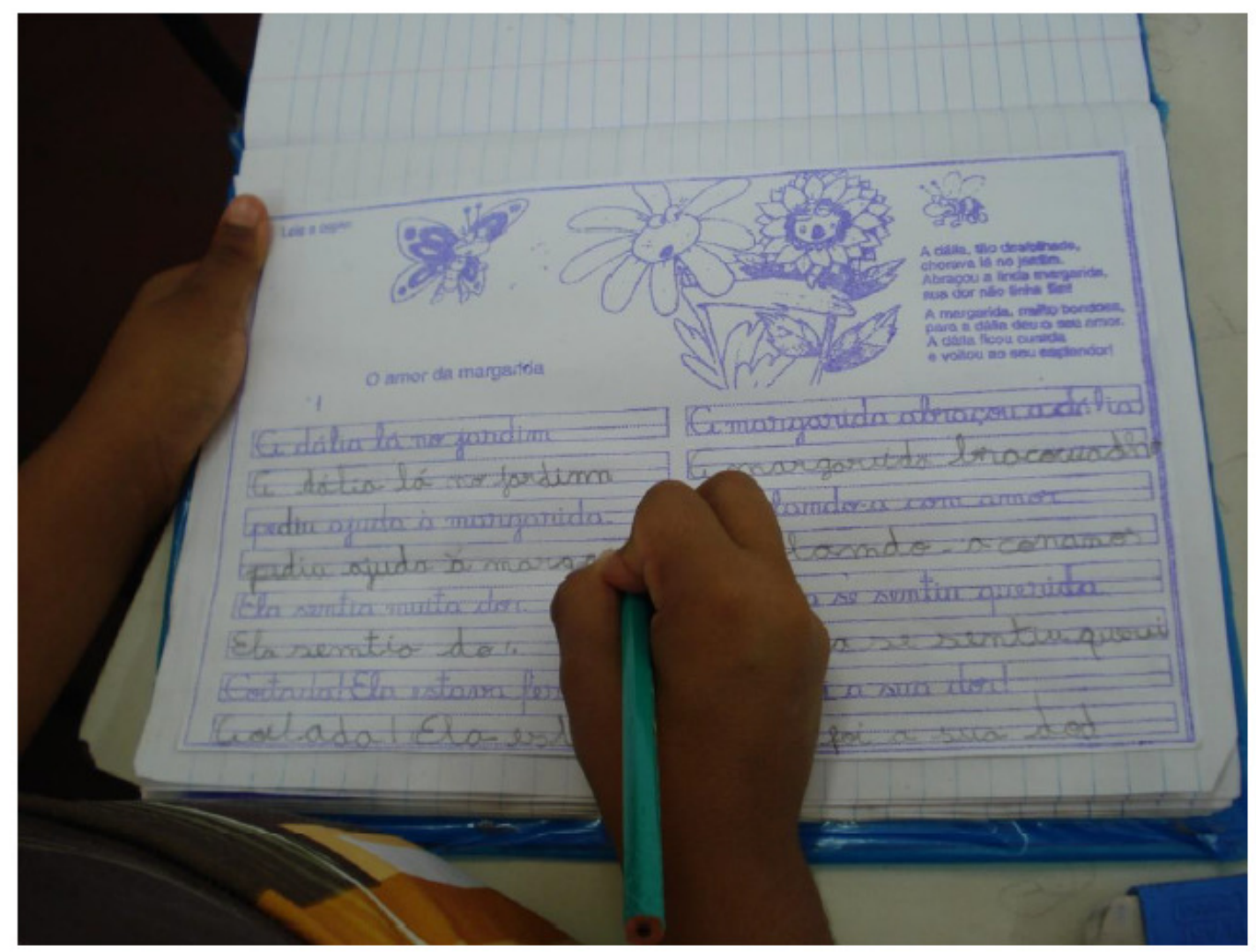

Figura 15. Atividade de caligrafia para crianças do $1^{\circ}$ ano do ensino fundamental. Fonte: Costa (2009), p. 141. 
Ao receber a atividade de caligrafia, uma das alunas demonstrou desagrado, e a pesquisadora buscou compreender o porquê, dando início ao diálogo abaixo:

Pesq.: [...] o que você acha dessa tarefa?

Diana: é ruim demais!!!

Pesq.: por quê?

Diana: porque tem que fazer isso aqui, esse aqui, ai! Difícil!!

Pesq.: já está até agoniada?

Diana: é, porque fazer cansa! (COSTA, 2009, p. 142-143).

A autora analisa que a criança, de forma crítica, julga a tarefa como sendo ruim, difícil, e cansativa. Por sua fala bastante expressiva, a criança parece não compreender porque precisa copiar o que já está escrito na folha (COSTA, 2009). A partir de seus resultados, Costa (2009) afirma que foi possível perceber que a retirada da criança de seis anos da Educação Infantil significou uma perda da oportunidade desta criança ser atendida "por uma proposta pensada e articulada no sentido de atendê-la em suas especificidades e de forma integral" (COSTA, 2009, p. 207).

Almeida (2012) apresenta alguns dos resultados encontrados em pesquisa realizada em 2010 em Tiradentes (MG), em que buscou compreender como as práticas alfabetizadoras estavam sendo realizadas com as crianças de seis anos no ensino fundamental. A pesquisa contou com observações de uma turma de $1^{\circ}$ ano de abril a dezembro, totalizando 47 dias observados. Analisando as práticas de leitura e escrita observadas, a autora constatou que foi bastante recorrente a prática de cópia de calendário e de pequenos textos, repetição de palavras soltas, e decodificação de sílabas. Segundo a autora,

A cópia do calendário se iniciava quando a professora registrava no quadro a saudação Boa tarde! e, logo em seguida, a data do dia por extenso. [...] Abaixo da data, eram registradas outras coisas que foram aumentando conforme o decorrer do ano. No começo, ela registrava só o alfabeto, em letras de forma maiúscula, e colocava cartões, com os numerais de zero a nove. Depois, ela passou a registrar também o nome da escola. Mais adiante, ampliou a sequência dos numerais e passou a registrá-los também no quadro. Depois, passou a escrever uma frase, envolvendo o nome da escola. Os alunos copiavam do quadro tudo que era anotado por ela. O tempo destinado a essa atividade girava em torno de 40 minutos, tempo necessário para que todos os alunos copiassem tudo (ALMEIDA, 2012, p. 7-8).

Além da cópia do calendário, eram frequentes atividades de cópia de pequenos textos, introduzidas no segundo semestre na rotina escolar das crianças. Em entrevistas com a professora, Almeida (2012) observou que esta concebia os exercícios de cópia como um 
caminho que poderia contribuir para a alfabetização das crianças. A fala da professora exprime sua compreensão sobre o trabalho de alfabetização:

A cópia do texto era mesmo aquela de... com a cópia do texto eles se... se evoluíam mais na escrita. Porque aquilo que você copia você memoriza mais. E a leitura era mesmo pra todos estarem... assim, a gente codificava, ia sílaba por sílaba, lendo junto, mesmo pra evoluir a leitura, na evolução da leitura mesmo. E pra que aqueles que não conseguiam ler sozinhos, com a minha ajuda e com a ajuda dos colegas, eles se habituariam a ler também. Muitos chegaram ao final do ano lendo, a maioria (ALMEIDA, 2012, p. 9).

Assim, observa-se também na pesquisa de Almeida (2012) que as práticas de alfabetização realizadas com o $1^{\mathrm{o}}$ ano mantêm-se as mesmas da antiga $1^{\mathrm{a}}$ série, sem qualquer modificação na metodologia de ensino. Para a autora, "a escola, ao desenvolver práticas como essas, tem tratado a linguagem escrita de modo abstrato e desconectado dos contextos sociais reais em que ela ocorre" (ALMEIDA, 2012, p. 13-14).

O ditado também foi uma atividade frequente no trabalho com o primeiro ano do ensino fundamental. Carneiro (2006) aborda essa questão com maior evidência em seu estudo, realizado em uma escola estadual de Belo Horizonte, por meio de observações em campo e entrevistas com a professora de primeiro ano, a diretora, a supervisora, e uma funcionária da Secretaria Estadual de Educação. A Figura 16 mostra um grupo de atividades de ditado feitas pelos alunos de primeiro ano.
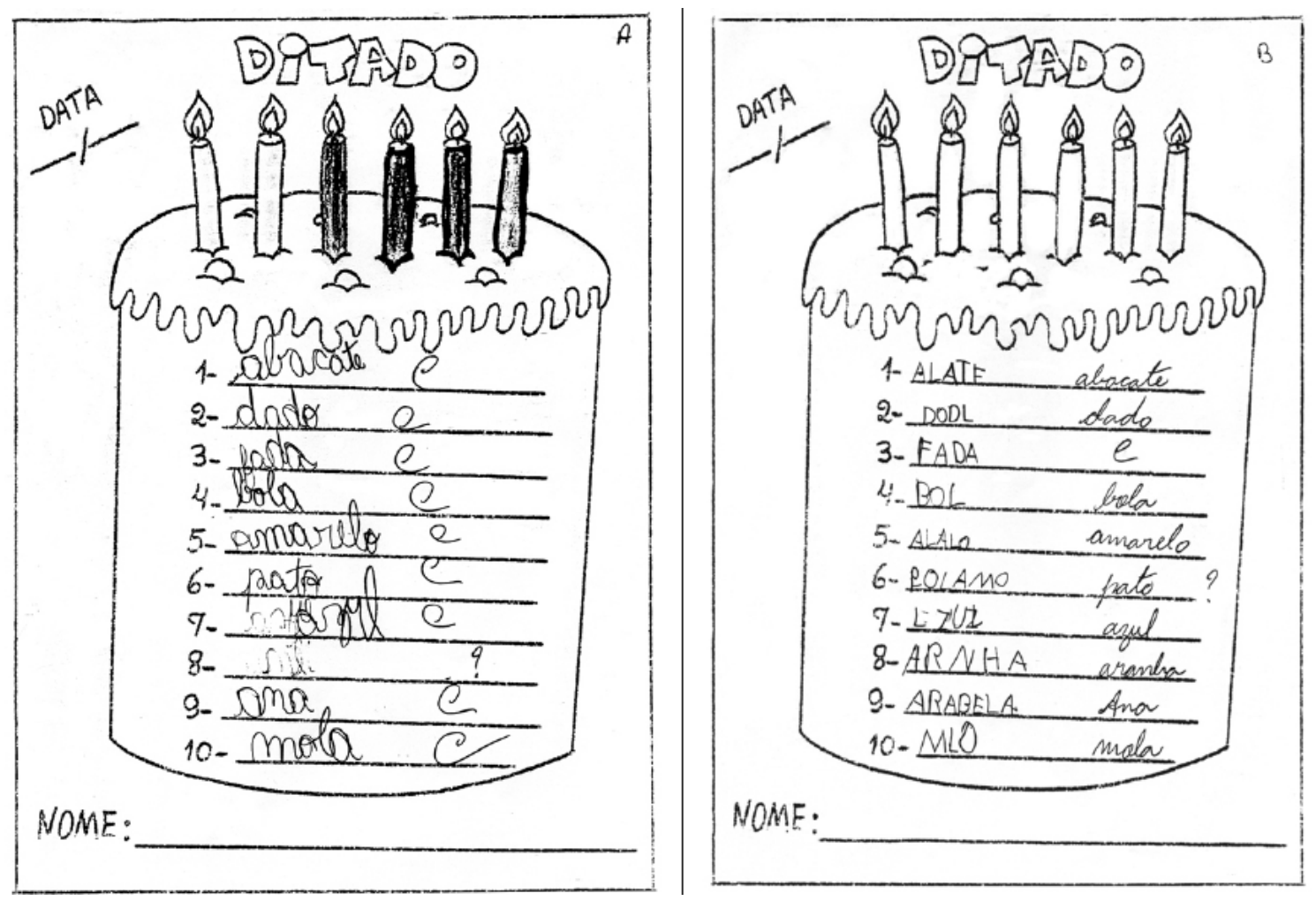


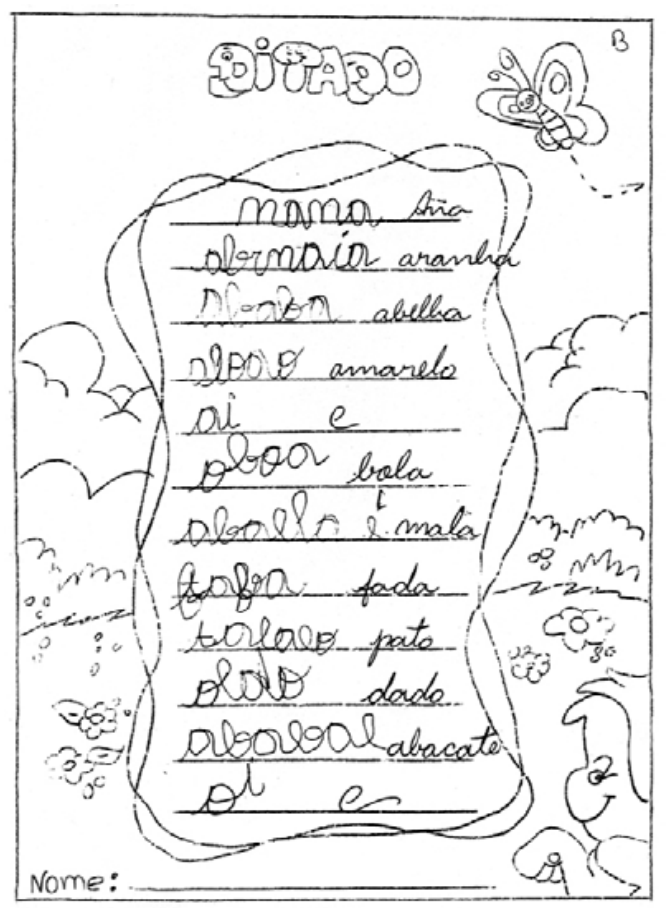

Figura 16. Atividade de ditado realizada por crianças de primeiro ano.

Fonte: Carneiro (2006), p. 182.

Para Carneiro (2006), o ditado é uma prática fortemente enraizada na escola no que refere ao trabalho de alfabetização. A autora pondera que "a utilização dessa estratégia com base em pressupostos associacionistas não contribui para a reflexão e restringe essa prática ao controle e verificação da escrita, funcionando apenas como estratégia de avaliação, e não como estratégia de ensino" (CARNEIRO, 2006, p. 184). Portanto, atividades pedagógicas que envolvam a repetição e associação de conteúdos pouco contribuem para a reflexão do sistema de escrita e de sua função comunicativa e social.

Zingarelli (2009) também observou em sua pesquisa, práticas de ensino descontextualizadas e bastante engessadas, sem flexibilidade para trabalhar com as demandas das crianças. A pesquisa envolveu observações em duas escolas da rede municipal e duas escolas privadas do município de Araraquara (SP). A autora discute que na rede municipal não havia orientações claras sobre o trabalho pedagógico com as crianças de $1^{\circ}$ ano, e que cada professor trabalhava da forma que acreditava ser mais produtivo. As práticas de ensino descontextualizadas e engessadas foram observadas nas escolas da rede municipal, como se observa no trecho abaixo de uma aula observada pela pesquisadora:

Professora Escola municipal I: B com A forma BA, B com E forma BE, B com I forma BI, B com O forma BO, B com U forma BU. Com a BA escrevemos BACIA. 
Aluno Escola municipal I, interrompendo a professora: Professora! Igual BANANA?

Professora Escola municipal I: Não, esta palavra não faz parte da lição de hoje! (Zingarelli, 2009, p. 130).

Observa-se que a alfabetização é concebida pela professora como decodificação de letras e sílabas, buscando ensinar as crianças a ler e escrever em atividades de 'juntar as letrinhas'. Além disso, ficou evidente a falta de flexibilidade de lidar com as demandas das crianças, e desvalorização da expressão do pensamento do aluno. Como questiona Zingarelli (2009), "apenas confirmar que a palavra começa com a mesma sílaba da palavra BACIA, traria algum empecilho para lição?” (p. 130). É evidente que não, pelo contrário, traria algum sentido ao conteúdo que estava sendo ensinado.

A pesquisa de Raniro (2009) também relata práticas bastante tradicionais no ensino da leitura e escrita. À semelhança do estudo de Almeida (2012), a pesquisadora também constatou neste estudo que a prática de cópia do cabeçalho era recorrente: "todo dia as professoras iniciam a lousa com o cabeçalho, que inclui o nome da escola e a data. Este é composto por nome da escola, seguido pelo nome do município, data e dia da semana" (RANIRO, 2009, p. 112). A Figura 17 mostra a organização da lousa com o cabeçalho, acrescido dos numerais de 0 a 50, prática iniciada no segundo semestre pelas professoras para o ensino da matemática. Também pode ser observada a prática de cópia de pequenos textos escritos na lousa (Figura 18).

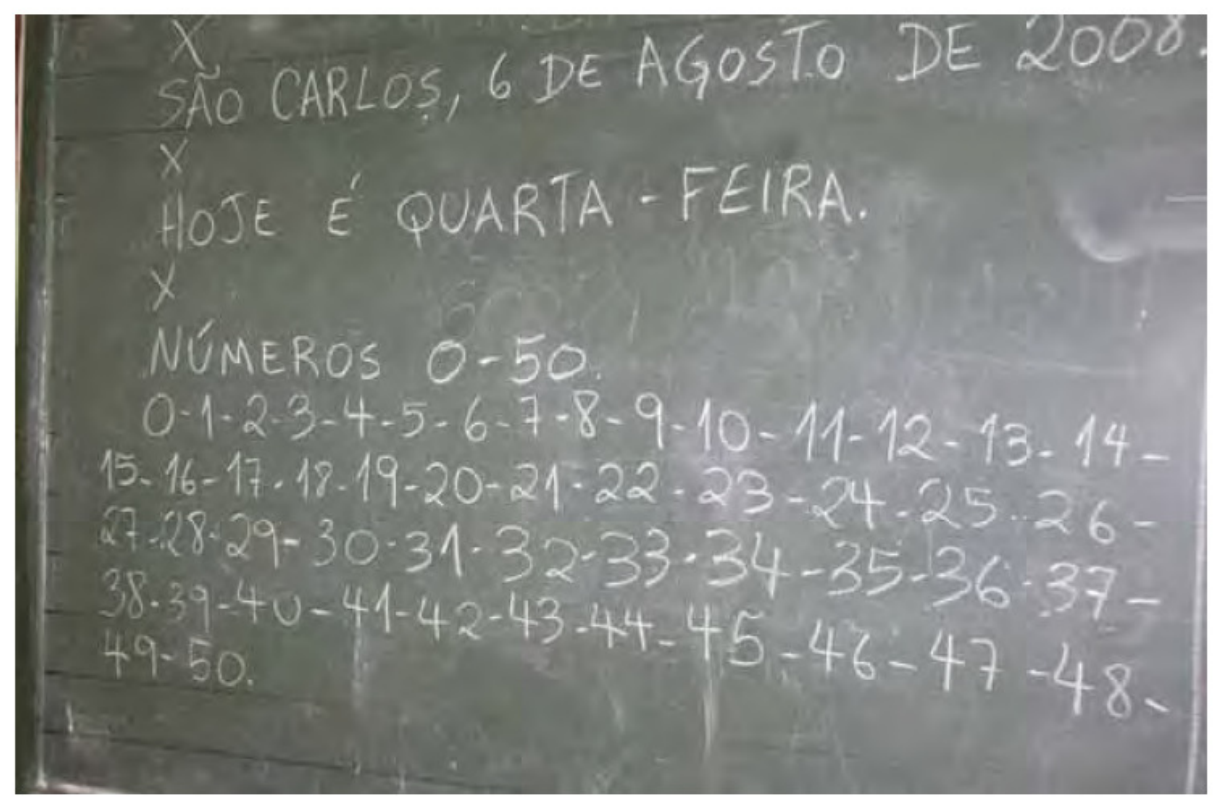

Figura 17. Organização da lousa para atividade de cópia do cabeçalho. Fonte: Raniro (2009), p. 119. 


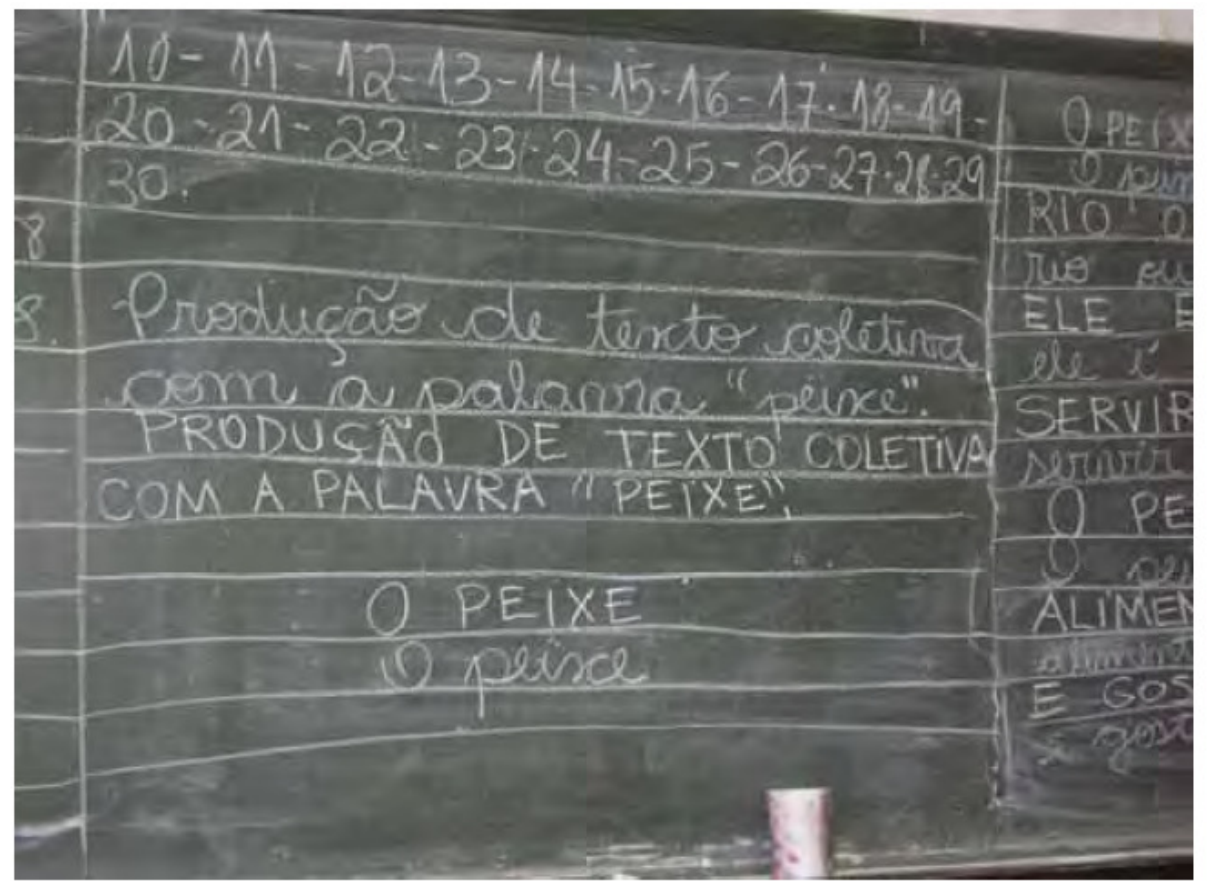

Figura 18. Organização da lousa para atividade de cópia de texto.

Fonte: Raniro (2009), p. 116.

Observa-se com as Figuras 17 e 18 a permanência de práticas tradicionais de ensino, comuns à antiga $1^{\mathrm{a}}$ série, também na escola pesquisada por Raniro (2009). Uma das crianças entrevistadas, quando questionada pela pesquisadora sobre o que a professora lhe ensina, cita a organização do calendário na lousa:

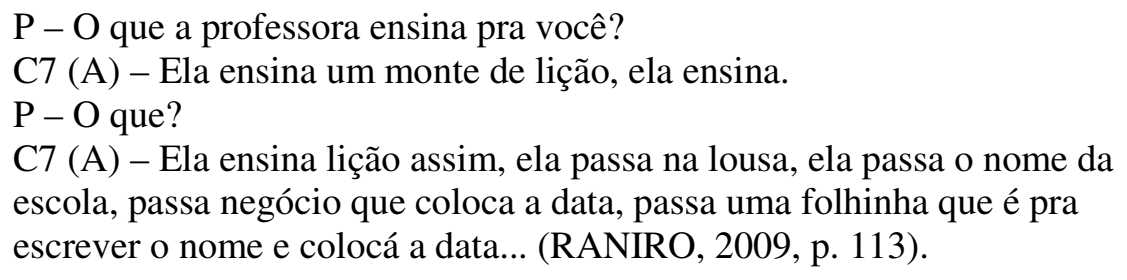

A fala desta criança parece refletir seu cotidiano escolar, entendendo como ensino as práticas formais de cópia do cabeçalho e outras atividades que a professora passa na "folhinha". Neste depoimento não se observa referência a elementos lúdicos, nem ao ensino contextualizado das demais áreas do conhecimento. O ensino é compreendido pela criança como algo sistematizado. Nos diálogos seguintes entre a pesquisadora e as crianças (C9 e C13), fica novamente evidente a ausência de vivências lúdicas e a compreensão de ensino como algo sistematizado: 
ensina... Ensina a lê.

$\mathrm{P}-\mathrm{E}$ fazer conta?

C9 (B) - A escrever...

$\mathrm{P}$ - Escrever. Joia. O que ce aprende então na escola?

C9 (B) - Eu aprendo a ler, a escrever (RANIRO, 2009, p. 118).

$\mathrm{P}-\mathrm{E}$ o quê que a professora ensina pra você (...)?

C13 (C) - A lê, a escrevê.

$\mathrm{P}-\mathrm{Que}$ mais?

C13 (C)- Só.

P - Só? A ler e a escrever? Ce gosta? Como que ela ensina a ler?

C13 (C) - Juntando as palavrinha. Ela fala pra juntar as palavrinha e, falando assim BA, pra falar BANANA, daí eu aprendo.

$\mathrm{P}$ - Legal... E que que ce aprende então aqui na escola?

C13 (C) - Há... Muitas coisas.

$\mathrm{P}-\mathrm{O}$ que?

C13 (C) - A lê, a escrever (RANIRO, 2009, p. 111).

O estudo de Brandão (2012) também mostra a manutenção de práticas tradicionais de alfabetização como o trabalho com as sílabas. Sua pesquisa, realizada em Porto Alegre, envolveu observação de uma turma de primeiro ano e entrevista com a professora da turma. A autora relata que a professora iniciou o processo de alfabetização ensinando as vogais, depois as consoantes, para então introduzir as sílabas. Em conjunto com os alunos, a professora estabelece um desenho ou símbolo que lembre cada sílaba trabalhada, conforme mostra a Figura 19.

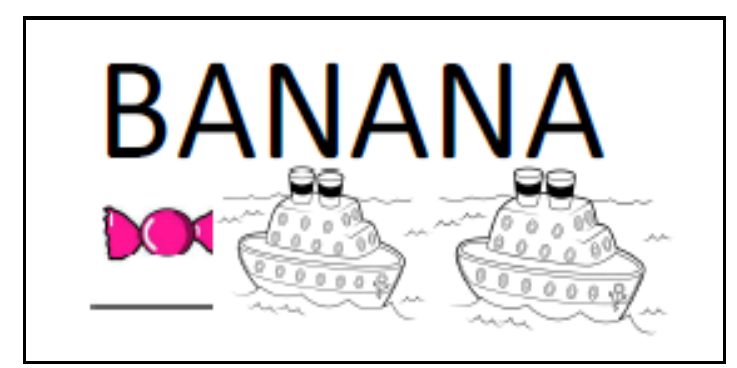

Figura 19. Atividade de associação desenho-sílaba proposta para alunos de $1^{\circ}$ ano. Fonte: Brandão (2012), p. 79.

Segundo Brandão (2012), a professora justificou a prática afirmando que os alunos memorizam o desenho e relembram a sílaba, para então formar as palavras.

Conforme afirma Britto (2005), é preciso ter claro que alfabetizar não significa formar a criança no domínio de uma técnica, mas sim inseri-la no mundo da escrita, "de modo que ela possa transitar pelos discursos da escrita, ter condições de operar criticamente com os 
modos de pensar e produzir da cultura escrita" (BRITTO, 2005, apud Oliveira, 2011, p. 9394).

No entanto, as práticas tradicionais de alfabetização observadas em grande parte das pesquisas analisadas nesta revisão, como a cópia de pequenos textos e palavras soltas, parecem não conferir sentido às práticas de leitura e escrita para as crianças. Abreu (2009) e Abreu (2010) mostram trechos de diálogos com as crianças de seis anos sobre a importância de ler e escrever:

Pesquisadora: E quando vocês aprenderem a ler, o que vocês vão fazer? Paulo: Muita coisa... Ler palavra, um bocado de coisa (ABREU, 2010, p. $67)$.

Ler e escrever é importante porque a gente aprende na escola e passa de ano. (Aluno da $1{ }^{\text {a }}$ Série)

É importante para nós passarmos para outra série. (Aluna da Série Introdutória)

Acho que é bom aprender ler e escrever, porque você pode aprender tudo que a tia ensina. (Aluna da $1^{\text {a }}$ Série)

(...) porque você tem que aprender pra poder passar de ano! (Aluno da $1^{\mathrm{a}}$ Série) (ABREU, 2009, p. 140).

A fala das crianças indica que sua compreensão da importância do ensino da leitura e escrita está mais relacionada às cobranças e à avaliação, sem nenhuma menção à importância social e comunicativa do nosso sistema de escrita, que vai muito além do "passar de ano".

A manutenção de práticas pedagógicas tradicionais da antiga $1^{\mathrm{a}}$ série indica que as concepções dos professores não foram alteradas com a implantação do ensino fundamental de nove anos. Apesar dos documentos oficiais conceberem a implantação da medida como "uma oportunidade preciosa para a práxis dos educadores" (BRASIL, 2004c), na prática as concepções e práticas de alfabetização se mantiveram as mesmas. Conforme afirmam Abdian e Ciardella (2011) a "atenção voltou-se para a preparação da criança e não para a preparação de uma nova concepção de criança, de educação e de escola fundamental” (p. 186).

Vale ressaltar, por fim, que não há uma única maneira de alfabetizar. Desse modo, entende-se que a adoção das práticas aqui apresentadas podem resultar na alfabetização dos alunos, porém, pouco contribuem para sua formação crítica quanto à leitura e escrita. Além disso, é importante destacar que a manutenção dessas práticas decorre de diferentes fatores, como deficiências na formação docente, as condições da oferta de ensino, e as cobranças sobre o trabalho docente focadas na alfabetização das crianças. 


\subsubsection{Contradições: orientações X cobranças.}

Alguns estudos ressaltam que também não houve mudanças quanto a hábitos típicos do ensino fundamental, como uma maior sistematização do ensino e uma disciplina rígida. A pesquisa desenvolvida por Malta (2012), cujo objetivo era analisar especialmente a questão curricular em meio a ampliação do ensino fundamental para nove anos, envolveu análise do currículo de duas escolas e entrevistas com seis professores de primeiro ano. Uma das professoras entrevistadas afirmou que um dos maiores problemas enfrentados na implantação foi a falta de estrutura da escola para se inserir o lúdico no cotidiano escolar e exigências de disciplina:

A professora critica a falta de estrutura para brincar e a transferência de hábitos do ensino fundamental para as crianças de seis anos como: fila, disciplina rígida, que são elementos fortemente presentes no cotidiano das crianças maiores e que também têm sido cobrados das crianças do primeiro ano (MALTA, 2012, p. 76).

Bonamigo (2010) também verificou a transferência de hábitos de disciplina característicos do ensino fundamental com as crianças de seis anos em sua pesquisa em 15 escolas de Várzea Paulista (SP). Apesar de não discutir muito a questão, a autora apresenta uma foto bastante ilustrativa (Figura 20), em que as crianças de seis anos transitam pela escola em formação de fila, mesmo após a aula no momento de ir para casa.

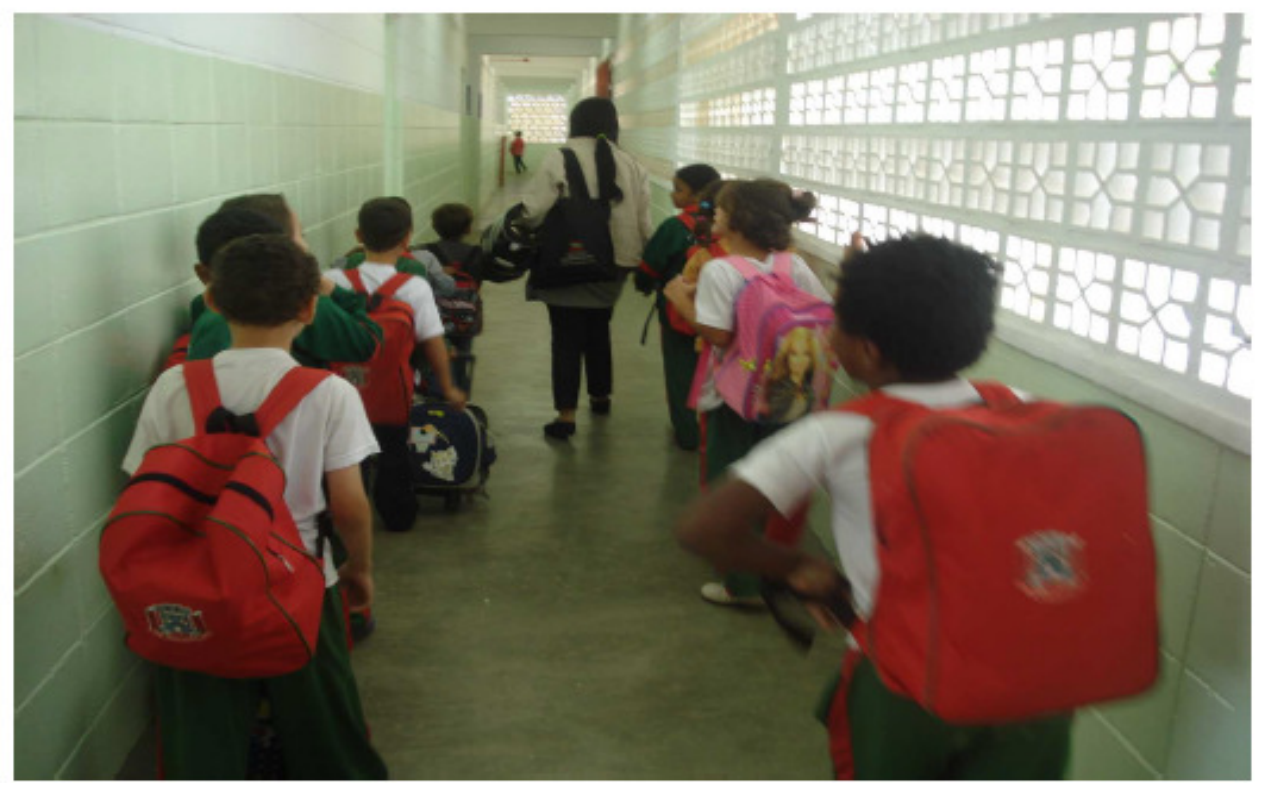

Figura 20: Crianças de seis anos indo para casa em fila.

Fonte: Bonamigo (2010), p. 155. 
Já na pesquisa de Raniro (2009), é apresentada a fala de uma professora que valida a disciplina rígida do ensino fundamental, pontuando que esta é necessária para que as crianças levem a sério o trabalho desenvolvido na escola.

Porque é escola e eles têm que levar a sério. Por mais que eles tenham seis anos, eles têm que começar a perceber que aquilo ali é uma coisa séria, que eles não vêm aqui pra brincar, que as atividades não são só brincadeiras. Que eles estão aprendendo uma coisa pra vida deles. (...) De manhã, eles não vem pra escola. Então eles podem muito bem brincar, ir com a mãe na loja. E na hora de aprender, tem que aprender (RANIRO, 2009, p. 141).

Outro elemento relevante da fala desta professora é a compreensão de brincadeira como incompatível com o processo ensino-aprendizagem. Borba (2007), no documento "Ensino fundamental de nove anos: orientações para a inclusão da criança de seis anos" (BRASIL, 2007c) do Ministério da Educação busca desconstruir esta visão e afirma sobre o brincar no ensino fundamental:

Seu lugar e seu tempo vão se restringindo à hora do recreio, assumindo contornos cada vez mais definidos e restritos em termos de horários, espaços e disciplina: não pode correr, pular, jogar bola etc [...]. Mas a brincadeira também é séria! E no trabalho muitas vezes brincamos e na brincadeira também trabalhamos (BORBA, 2007, p.35).

A pesquisa de Amaral (2008) também traz resultados que indicam sistematização do ensino e meta exigentes para o $1^{\circ}$ ano. Este estudo é bastante interessante por acompanhar a transição de Educação Infantil para Ensino Fundamental, ocorrido, de forma atípica, no meio do ano letivo. Segundo a pesquisadora, na transição da Educação Infantil para Ensino Fundamental as crianças não passaram por modificações do mobiliário nem estrutura da escola, que por atender a etapa da Educação Infantil já contava com parque e mobiliário adequado, e com a sala organizada de forma semelhante às de Educação Infantil. A grande mudança foi a organização do tempo e da rotina, com maior sistematização do ensino e do tempo. Professores e alunos afirmam que o tempo destinado às brincadeiras diminuiu, e os conteúdos são trabalhados de forma mais intensa "para dar conta da cobrança":

Não que antes eu não trabalhasse as letras e os números, trabalhava sim, mas de forma lúdica, conforme a curiosidade deles. Hoje existe um compromisso com a sistematização, preciso atingir os objetivos (AMARAL, 2008, p. 7374). 
A partir do depoimento desta professora infere-se que a questão dos objetivos e metas a cumprir pode ser um limitador no trabalho integral com as crianças de seis anos. Abreu (2009) descreve que as metas para o trabalho com o primeiro ano eram bastante exigentes. Através de contato com o material distribuído aos docentes em formação, a autora observou grande ênfase na alfabetização e metas exigentes no ensino da escrita, como o trabalho sistemático de produção de textos de gêneros diversos, com planejamento do texto de acordo com o tema central, objetivos, contexto de circulação, e vocabulário adequado ao contexto. A Figura 21 apresenta as capacidades na produção da escrita a serem trabalhadas nos três primeiros anos do ensino fundamental, em que "I" significa "introduzir", "T" significa "trabalhar sistematicamente", e "C" significa "consolidar" as capacidades (conforme explica legenda abaixo).

\begin{tabular}{|c|c|c|c|}
\hline CAPACIDADES & $1^{\circ}$ ano & $2^{\circ}$ ano & $3^{\circ}$ ano \\
\hline $\begin{array}{l}\text { Compreender e valorizar o uso da escrita, } \\
\text { com diferentes funçṓes, em diferentes gêneros. }\end{array}$ & $\mathrm{I} / \mathrm{T} / \mathrm{C}$ & $\mathrm{T} / \mathrm{C}$ & $\mathrm{T} / \mathrm{C}$ \\
\hline $\begin{array}{l}\text { Produzir textos escritos de gêneros diversos, adequados } \\
\text { aos objetivos, ao destinatário e ao contexto de circulaçắo: }\end{array}$ & $\mathrm{I} / \mathrm{T} / \mathrm{C}$ & $\mathrm{T} / \mathrm{C}$ & $\mathrm{T} / \mathrm{C}$ \\
\hline $\begin{array}{l}\text { (1) Dispor, ordenar e organizar o próprio texto de } \\
\text { acordo com as convençóes gráficas apropriadas; }\end{array}$ & I & 1 & T/C \\
\hline $\begin{array}{l}\text { (II) Escrever segundo o princípo alfabérico } \\
\text { e as regras ortográficas; }\end{array}$ & I & I & T/C \\
\hline $\begin{array}{l}\text { (iII) Planejar a escrita do texto considerando } \\
\text { o terna central e seus desdobramentos; }\end{array}$ & $\mathrm{I} / \mathrm{T} / \mathrm{C}$ & & T/C \\
\hline $\begin{array}{l}\text { (iv) Organizar os próprios textos segundo os } \\
\text { padróes de composiçăo usuais na sociedade }\end{array}$ & I/T/C & I/T/C & T/C \\
\hline $\begin{array}{l}\text { (v) Usar a variedade linguística própria à situaçáo } \\
\text { de produçáo e de circulaçáo, fazendo cscolhas } \\
\text { adequadas quanto ao vocabulário e a gramática; }\end{array}$ & I/T/C & I/T/C & T/C \\
\hline $\begin{array}{l}\text { (vi) Usar recursos expressivos, estilísticos e literários, } \\
\text { adequados ao gênero e aos objetivos do texto; }\end{array}$ & IIT/C & I/TiC & $\mathrm{T} / \mathrm{C}$ \\
\hline $\begin{array}{l}\text { (viI) Revisar e elaborar a própria escrita, segundo } \\
\text { critérios adequados aos objetivos, ao destinatário e } \\
\text { ao contexto de circulaçắo previstos. }\end{array}$ & I & $\mathrm{T}$ & $T / C$ \\
\hline
\end{tabular}


Na gradação dos tons de cinza apresentados nos quadros do volume 2, o tom mais claro significa que a "capacidade" deve ser introduzida ou retomada, caso já tenha sido objeto de ensino -aprendizagem em momentos anteriores. O tom médio significa que a capacidade deve ser trabalhada de maneira sistemática, com vista ao domínio pelos alunos e o tom mais escuro significa que a capacidade, já trabalhada sistematicamente, deve ser enfatizada de modo a assegurar sua consolidação. As letras inseridas nas quadrículas representam $\mathrm{I}=\mathrm{Introduzir}, \mathrm{R}=$ Retomar, $\mathrm{T}=$ Trabalhar sistematicamente e $\mathrm{C}=\mathrm{Consolidar}$.

Figura 21. Metas do ensino da escrita no $1^{\circ}, 2^{\circ}$ e $3^{\circ}$ anos do ensino fundamental. Fonte: Abreu (2009), p. 98.

Como já afirmado neste texto, o grande complicador de metas e objetivos tão específicos para o ensino da escrita é a recorrente compreensão de que não é possível trabalhar estas capacidades através do ensino das demais áreas do conhecimento e da ludicidade, dando espaço para o ensino sistematizado, com práticas descontextualizadas e sem sentido para as crianças, como a cópia e o ditado discutidos no subtópico anterior.

Moro (2009), em pesquisa realizada em Curitiba (PR) por meio de entrevistas com seis professoras de primeiro ano, aponta que elas vivenciam algumas tensões e impasses decorrentes das expectativas da cultura escolar, própria do ensino fundamental. Os depoimentos abaixo demonstram os conflitos vivenciados pelas professoras.

[...] eu senti que esse ano houve uma cobrança maior em relação a conteúdos. Então,... eu também tenho uma filha de cinco anos que saiu do Jardim II e foi para o primeiro ano sem fazer o... O antigo pré, né?! Aí, eu como mãe e como professora, eu sinto que estou... roubando a infância dessas crianças. Eu tava me sentindo uma mísera já... E tem a cobrança dos pais: "meu filho está no primeiro ano, quando você vai ensinar a ler e escrever?" (BEATRIZ).

Como eu te falei, eu trabalhei com a Educação Infantil, então eu sinto um certo remorso pelas crianças assim novinhas. As crianças poderiam estar aproveitando um pouquinho mais e não estão. E tendo que forçar elas a fazerem certas coisas, então é uma parte da infância delas que elas estão perdendo.[...] eles estão numa idade de brincar... (PAULA).

[...] as crianças se mexem, fazem barulho. Então aquilo começa agitar... aí tem aquela agitação e eles começam a ficar inquietos... (MARIA LUIZA). (MORO, 2009, p. 212-213).

De acordo a autora, os depoimentos destas professoras indicam que há na cultura do Ensino Fundamental um risco grande de se anularem as culturas da infância, "substituindo-as pelas atividades de estudo sistemático tipicamente escolares (cópia e escrita no caderno ou livro, resolução de problemas numéricos, em geral realizadas individualmente)" (MORO, 2009, p. 213). Assim, observa-se uma dicotomia entre as particularidades infantis e as 
exigências acadêmicas ou escolares, representadas principalmente pela sistematização da linguagem escrita, bastante valorizadas em nossa cultura.

Retomando a pesquisa de Bonamigo (2010), a autora disserta sobre currículo em seu trabalho de mestrado, e relata resultados importantes para esta discussão. A questão norteadora do trabalho é "qual é o currículo que vem sendo produzido para as crianças de seis anos?". Para responder essa questão, a autora analisou as narrativas de 15 professoras de $1^{\circ}$ ano de Várzea Paulista (SP). Dentre estas professoras, havia algumas que lecionaram na antiga $1^{\text {a }}$ série e outras que lecionaram na Educação Infantil com crianças de seis anos. Segundo Bonamigo (2010), foi possível perceber algumas diferenças nas práticas pedagógicas das professoras, de acordo com suas experiências prévias - enquanto uma professora que sempre lecionou para $1^{\mathrm{a}}$ série fala da centralidade na alfabetização, outra que lecionava na Educação Infantil fala da necessidade do lúdico em seu trabalho e de não ter uma rotina rígida com as crianças.

Apesar de notar o esforço das docentes em modificar sua prática pedagógica para atender às orientações, a pesquisadora constatou que as práticas desenvolvidas pelas professoras se mantinham praticamente as mesmas desenvolvidas em suas experiências anteriores. Bonamigo (2010) verificou também em sua pesquisa que o currículo desenvolvido no $1^{\circ}$ ano não atendia às necessidades e direitos da criança de seis anos.

Apesar do discurso da garantia do direito à infância permear as propostas colocadas em prática, a organização do trabalho e as atividades propostas mostram a infância negada - tempos e espaços pré determinados com participação mínima dos desejos das crianças (BONAMIGO, 2010, p. 154).

A pesquisadora caracteriza o currículo para as crianças de seis anos no Ensino Fundamental como um não-lugar, que "numa instabilidade de características relativas a ele, se apropria do lugar do fundamental como um apartamento alugado" (p. 151). Nesse sentido, apesar de serem crianças de seis anos, elas estão inseridas no contexto do Ensino Fundamental, caracterizado pelo ensino mais rígido e sistematizado do que na Educação Infantil:

Mesmo que brincadeiras, músicas, jogos, ludicidade, materiais concretos, parques e outras palavras que as professoras usam ao falar das crianças de seis anos façam total sentido nesse contexto, falar disso no Ensino Fundamental parece falar de algo que está descontextualizado (BONAMIGO, 2010, p. 152). 
Neste contexto, surgem situações como a de uma das professoras participantes da pesquisa de Bonamigo (2010), que contou que fecha a porta da sala de aula porque considera que as demais professoras irão recriminar seu trabalho com o primeiro ano por envolver mais atividades lúdicas que os demais anos.

Infelizmente, situações em que professores se sentem recriminados ao desenvolver trabalhos lúdicos não são exclusivas da realidade pesquisada por Bonamigo (2010). Na pesquisa de Abreu (2009) também é relatada essa situação. A professora de $1^{\circ}$ ano manifestou ao longo da entrevista que cotidianamente recebia reclamações de outros profissionais da escola (professores e profissionais da limpeza). As reclamações referiam-se ao barulho quando dava uma brincadeira, à sujeira do pátio quando deixava seus alunos desenharem no chão (amarelinha, jogo da velha, esquema corporal e outros) ou levava os alunos na terra/grama, e à sujeira da sala de aula quando fazia atividades com diferentes materiais (tintas, massas de modelar, preparação de receitas comestíveis) (ABREU, 2009).

Todas essas atividades são diferentes formas das crianças se apropriarem dos espaços e vivenciarem experiências lúdicas, sendo importantes que estejam contempladas no cotidiano escolar. A sua não valorização pelos demais profissionais da escola acabou gerando limitações para o trabalho pedagógico da professora, colocando-a em conflito, como se observa em sua fala:

Eu acho que tudo é muito contraditório você tem que dar autonomia à criança, mas é cobrado que você corte, discipline a criança demais, não pode sair da sala, não pode fazer barulho! (ABREU, 2009, p. 106).

Mais uma vez, vemos a importância da formação docente e tomadas de decisão envolver a participação dos demais professores do ensino fundamental para orientá-los quanto a nova proposta para esta etapa de ensino. Conforme afirma Abreu (2009), se faz necessário "repensar coletivamente as rotinas que são estabelecidas nos interiores das instituições escolares com vistas à reflexão sobre o quê, para quem e o como ensinar” (p. 106).

Assim, percebe-se que as cobranças existem tanto para a alfabetização das crianças de seis anos, quanto para discipliná-las. Ainda, é possível observar com os resultados das pesquisas desta revisão que as cobranças partem de órgãos públicos (por meio das avaliações e metas pré-estabelecidas), dos professores dos demais anos do ensino fundamental (que cobram disciplina), dos próprios professores de primeiro ano (que valorizam a alfabetização e 
disciplina), e também dos pais e familiares, que esperam que seus filhos sejam alfabetizados no $1^{\circ}$ ano.

Sobre a cobrança por parte dos pais, estudos como Almeida (2011), Rocha (2010), Toscano e Saito (2009), Portella e Hickel (2010) e Rosa, Jacomini e Alencar (2011), relatam em suas pesquisas a presença da expectativa e pressão dos pais para a alfabetização de seus filhos no $1^{\mathrm{o}}$ ano. Almeida (2011), por meio de entrevista com supervisora da Secretaria Municipal de Educação da cidade de São Paulo, verificou que os pais mantêm as expectativas do trabalho feito com a antiga $1^{a}$ série: "as famílias, muitas vezes, apresentam a concepção de que, já que a criança está na 'escola' (no contraponto ao 'prezinho'), é preciso ter 'caderno cheio"”. (ALMEIDA, 2011, p. 169-170).

Rocha (2010) buscou investigar a visão de pais/familiares sobre o ensino fundamental de nove anos e, para isso, entrevistou 58 pais/familiares de crianças de seis anos de cinco escolas localizadas em região de periferia. A pesquisa foi desenvolvida em 2006, primeiro ano de implantação do ensino fundamental de nove anos no município do interior paulista (nome não informado). Segundo a pesquisadora, os familiares se mostraram predominantemente favoráveis à ampliação do ensino fundamental, decorrente de expectativas de alfabetização das crianças. Assim, avaliaram de modo positivo atividades de leitura/escrita no primeiro ano, criticaram a baixa frequência das mesmas no cotidiano escolar e opuseram-se à existência de outras atividades no currículo, sobretudo às atividades lúdicas (ROCHA, 2010). A fala de uma das mães participantes da pesquisa mostra a crítica ao trabalho desenvolvido pela professora pela baixa frequência de atividades de leitura e escrita:

Aí teve o problema da lição também. Eu perguntava: "Paula, cadê a lição?". "Nós fez lição, mãe". "Paula, mas cadê a lição? A gente abre este caderno, não tem nada!!”. Eu falei pra ela assim: "ai, sua professora não está ensinando ninguém". Eu xinguei: "sua professora é burra!!". Mandei um bilhetão enorme para a professora. Eu queria saber. Aí a professora mandou outro bilhete, explicando o negócio da escola de 9 anos. Ai, meu deus. Ela falou que as crianças entravam agora com 6 anos, que era a escola de 9 anos, que tinha agora um projeto, que era mais devagar mesmo. Eu falei: "Então, peraí, é como se fosse uma creche?!? Porque, pra mim, isto aqui está igual a uma creche!! Parece um prezinho. Está aprendendo o que aprende numa creche, num prezinho. Era para aprender a escrever, a ler, todo aquele processo". (...) Aí, ela [a professora] ficou conversando comigo, tentando enfiar isso na minha cabeça (ROCHA, 2010, p. 492-493).

A partir da fala desta mãe e dos demais familiares entrevistados, a autora infere que, para os familiares, boas professoras são aquelas que investem de modo sistemático, rigoroso e 
em alta frequência na aprendizagem de determinados conteúdos, dentre os quais a alfabetização é vista como prioridade.

O estudo de Fontes (2009) também teve como participantes os pais e familiares de alunos do $1^{\mathrm{o}}$ ano, com objetivo de analisar os impactos da ampliação do ensino fundamental de nove anos sobre as expectativas e estratégias dos pais quanto à escolarização mais precoce das crianças. Realizado em Araraquara (SP), o estudo envolveu entrevistas com 56 pais/familiares de crianças de duas turmas de $1^{\circ}$ ano, de duas diferentes escolas da rede municipal. Segundo a autora, diante das expectativas das famílias para a escolarização das crianças de seis anos no ensino fundamental, foi possível constatar que os pais se mostravam favoráveis ao ingresso antecipado das crianças. Ao serem questionados sobre o acham que deve ser ensinado no $1^{\circ}$ ano com as crianças de seis anos, a maior parte das famílias afirmou que espera que os filhos sejam alfabetizados, como se observa no depoimento de quatro familiares transcritos a seguir:

Já dá pra aprender bastante coisa, palavras, alfabeto. Começar a aprender a ler.

Ler, escrever e contar.

Bem a alfabetização, tudo bem que as ciências tem que ter, corpo humano, mas ficar mais focado no Português e na Matemática.

Sair lendo, escrevendo bem. (FONTES, 2009, p. 103-104).

Assim, observa-se que a aprendizagem de leitura e escrita foi bastante valorizada pelos pais também no estudo de Fontes (2009). Apesar alguns pais defenderem que o $1^{\circ}$ ano fosse "mais infantilizado" ou "como se fosse uma pré-escola" (FONTES, 2009, p. 104), a maioria demonstrou expectativas de alfabetização no $1^{\circ}$ ano.

Toscano e Saito (2009) também observaram a presença de expectativas e pressão dos pais para a alfabetização as crianças de seis anos. Para os autores, neste contexto, a atuação de cada professor parece resultar de uma articulação de diferentes fatores que se influenciam mutuamente: os alunos, a pressão dos pais, os recursos disponíveis, as experiências anteriores e o contexto específico da escola (TOSCANO e SAITO, 2009).

A pesquisa traz interessantes achados sobre o movimento do mercado educacional no contexto do ensino fundamental de nove anos. Em seu estudo, os autores relatam que as escolas da rede pública não haviam ainda implantado o ensino fundamental de nove anos em Londrina e região em 2007 (ano da coleta de dados), o que os levou a fazer sua pesquisa em 
escolas privadas - algumas se adiantaram e já haviam implantado a mudança. Segundo os autores, diante da proposta de ampliação do ensino fundamental e reformulação do currículo, as empresas de produção de material didático "se agilizaram" no oferecimento de material didático para esse novo trabalho pedagógico escolar, ainda que num primeiro momento o material ofertado tivesse se mantido inalterado no seu conteúdo em relação ao antigo pré III (TOSCANO e SAITO, 2009).

$\mathrm{Na}$ ausência de diretrizes, orientações e eventos por parte de órgãos educacionais públicos as empresas que atuam no mercado educacional "ocuparam" o novo espaço oferecendo materiais didáticos e/ou cursos que pretendiam colaborar para o direcionamento das ações pedagógicas (TOSCANO e SAITO, 2009, p. 162).

Segundo os autores, também as escolas viram a ampliação do ensino fundamental como "possibilidade de oferta de um novo 'produto' na disputa pelo mercado educacional" (TOSCANO e SAITO, 2009, p. 162), e se adiantaram na oferta do mesmo. Diante deste contexto, as professoras se apoiavam em suas experiências anteriores e nos materiais específicos que tinham à disposição para tentar "corresponder às expectativas das respectivas instituições escolares, que tentavam oferecer ao seu público um novo 'produto', e também dos pais de seus alunos, que não só tinham expectativas, mas também faziam pressão pela alfabetização de seus filhos" (TOSCANO e SAITO, 2009, p. 163).

Buscando finalizar este subtópico, trazemos a fala de uma professora entrevistada por Moro (2009), que reflete as questões aqui abordadas: as contradições entre as orientações e a prática, as cobranças provenientes de diversas frentes, e a insegurança do professor em meio a estes conflitos e tensões.

[...] tem uma distância entre a invenção, a proposta e a realidade. A diferença é muito grande. [...] Então... esta coisa, do que os pais querem, do que a escola quer do que o contexto maior quer, você meio... não sabe onde vai chegar, você tem que meio... ir tentando acertar... meio por tentativas... por erros e acertos. [...] Quando você questiona, no começo do ano quando nós questionamos: "Nós vamos alfabetizar como se fosse uma primeira série das antigas?" Então, elas falavam: "depende, depende da tua turma". Sabe... então tudo depende, elas não chegam e dizem realmente, é pra fazer isto, é para fazer aquilo. [...] é uma coisa que você tem que ir meio deduzindo,... caminhando um caminho nebuloso (MORO, 2009, p. 248). 
3.3.4 Breves considerações sobre a questão da avaliação no ensino fundamental de nove anos.

Neste tópico será discutida a avaliação no primeiro ano do ensino fundamental em dois âmbitos: a avaliação escolar, elaborada pelas professoras, e a avaliação externa, padronizada, criada pelos órgãos públicos como um mecanismo para avaliar o ensino. Apesar da questão da avaliação ter sido um tema pouco frequente nos trabalhados analisados, os trabalhos que abordam esta temática trouxeram dados interessantes para esta discussão, que serão aqui apresentados e discutidos.

Raniro (2009) trata a questão da avaliação com maior atenção, descrevendo detalhadamente como ocorria a avaliação das professoras entrevistadas, que lecionavam para turmas de primeiro ano em uma escola da rede municipal de São Carlos (SP). Segundo a autora, as professoras avaliam os alunos mensalmente, de forma individual. Enquanto os demais alunos faziam uma atividade, uma criança por vez era solicitada a ir até a mesa da professora para fazer a avaliação, que também era denominada pelas professoras como sondagem, ou portfólio. Como afirma a pesquisadora, esta sondagem funcionava da seguinte forma:

a professora estabelece um campo semântico (por exemplo, festa junina) e solicita aos alunos que escrevam algumas palavras relacionadas a este campo (uma polissílaba, uma trissílaba, uma dissílaba, e uma monossílaba) e uma frase (também relacionada). Depois de escrever cada palavra ou a frase, o aluno tem que ler o que escreveu, apontando com o dedo, a leitura. Todas as palavras e a frase são pensadas previamente. $\mathrm{O}$ formato pode vir a ser alterado, caso a professora julgue pertinente; por exemplo, ao invés de pedir que a criança escreva palavras, solicitar que escreva frases (p. 127).

Assim, o objetivo com essa avaliação mensal era verificar o nível de escrita no qual a criança se encontrava no mês em vigência e no final do processo. A Figura 22 mostra a avaliação mensal realizada pelas professoras nos meses de abril e maio. 

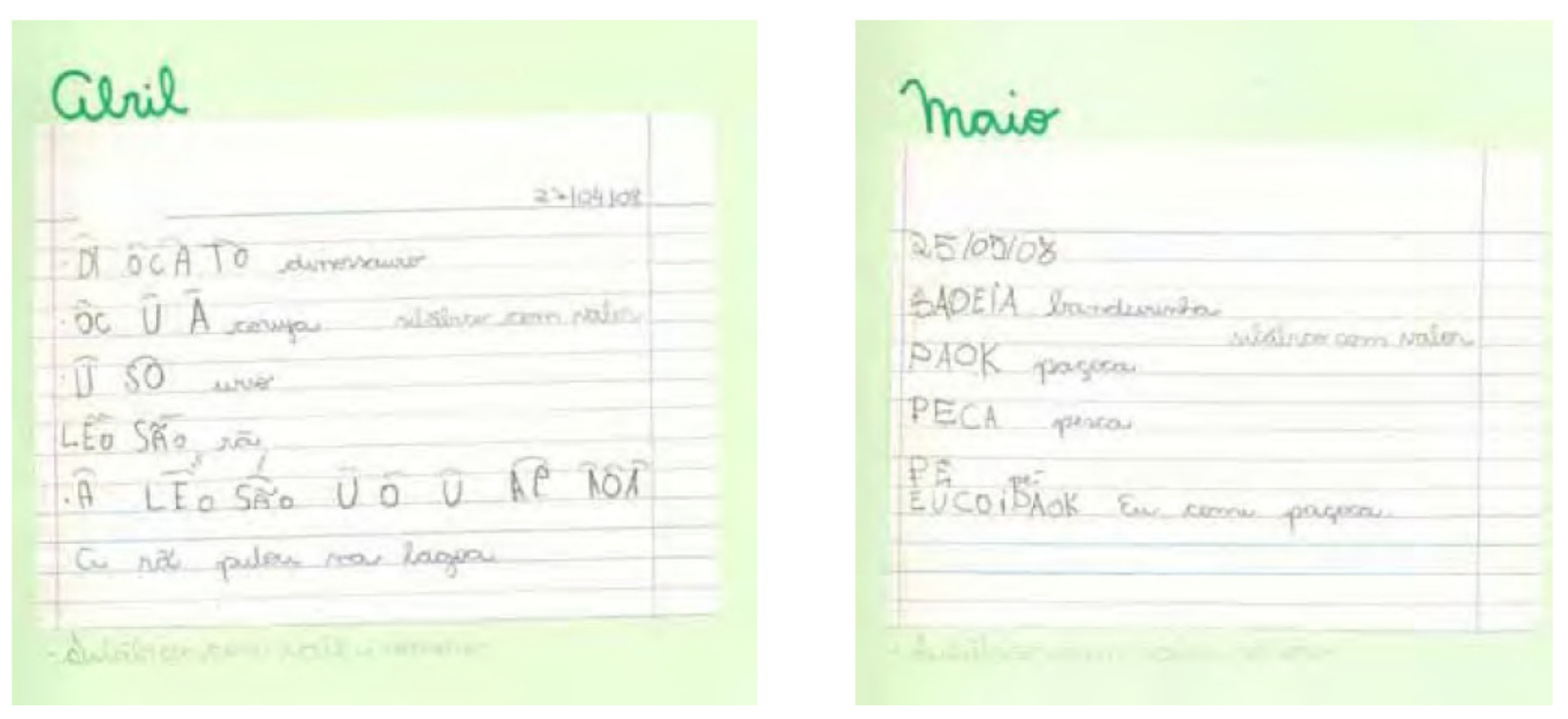

Figura 22. Exemplos de avaliação mensal realizada pelas professoras com as crianças de primeiro ano.

Fonte: Raniro (2009), p. 131.

Como se observa na Figura 22, as sondagens eram realizadas de acordo com os projetos temáticos desenvolvidos no mês, e envolviam (no primeiro semestre) a escrita de quatro palavras e uma pequena frase. Assim, em abril a temática escolhida foi "animais", e as palavras selecionadas foram "dinossauro", "coruja", "urso" e "rã". A frase foi: "A rã pulou na lagoa". Já em maio, a temática abordada foi "festa junina", e as palavras foram "bandeirinha", "paçoca", "pesca" e "pé” (de pé-de-moleque). A frase foi: "Eu comi paçoca".

Assim, observa-se que a avaliação mensal realizada por estas professoras era um trabalho processual de acompanhamento dos alunos. Para a autora, a periodicidade com a qual essas sondagens eram realizadas permitia ao professor ter clareza do processo de aprendizagem da leitura e da escrita de seus alunos, e com isso averiguar se ocorreu avanço, retrocesso ou estabilização.

No entanto, é importante destacar que esta forma de avaliação trata-se de um trabalho constante de acompanhamento dos alunos e exige domínio da teoria que embasa a prática. Como afirma Correa (2010), “vale ressaltar o quanto essas 'sondagens' se tornaram processos mecânicos, que, sem um conhecimento profundo sobre a própria teoria que embasa a prática, acaba se tornando, no mais das vezes, um instrumento de mera classificação dos alunos" (CORREA, 2010, p. 323).

A pesquisa de Costa (2009) mostra que, no contexto investigado, as crianças de primeiro ano faziam avaliações trimestrais, elaboradas pelas professoras para acompanhar o 
desenvolvimento dos alunos a pedido da coordenação da escola. Havia, também outra avaliação, de caráter quantitativo, elaborada por profissionais da Secretaria e aplicada em turmas escolhidas pela Secretaria para fazer uma avaliação por amostragem. Como afirma Costa (2009), "a escolha de uma sala para proceder a uma avaliação não representa a situação da escola, porque pode ser que a sala escolhida tenha sido a que teve maior número de problemas, ou a que foi melhor" (p. 123), o que pode enviesar os dados obtidos com este tipo de avaliação. A forma como esta avaliação ocorria era criticada pelos professores, como expressa a fala de uma das professoras entrevistadas:

A gente não pode nem ver a prova, só o professor na sala, a gente vê quando assim, vem com o envelope lacrado, parece aquela coisa de concurso, lacrado, entra, aplica, é uma questão de número mesmo, a escola comparada com o ano passado, qual foi o resultado do ano passado? 48\%? Qual foi o resultado desse ano? 50\% Ah então está melhorando (COSTA, 2009, p. 124).

A fala desta professora evidencia sua crítica à forma como ocorre a prova, com toda a seriedade de um "concurso", aplicada às crianças de seis anos. A Figura 23 mostra as crianças preparadas para iniciar esta avaliação.

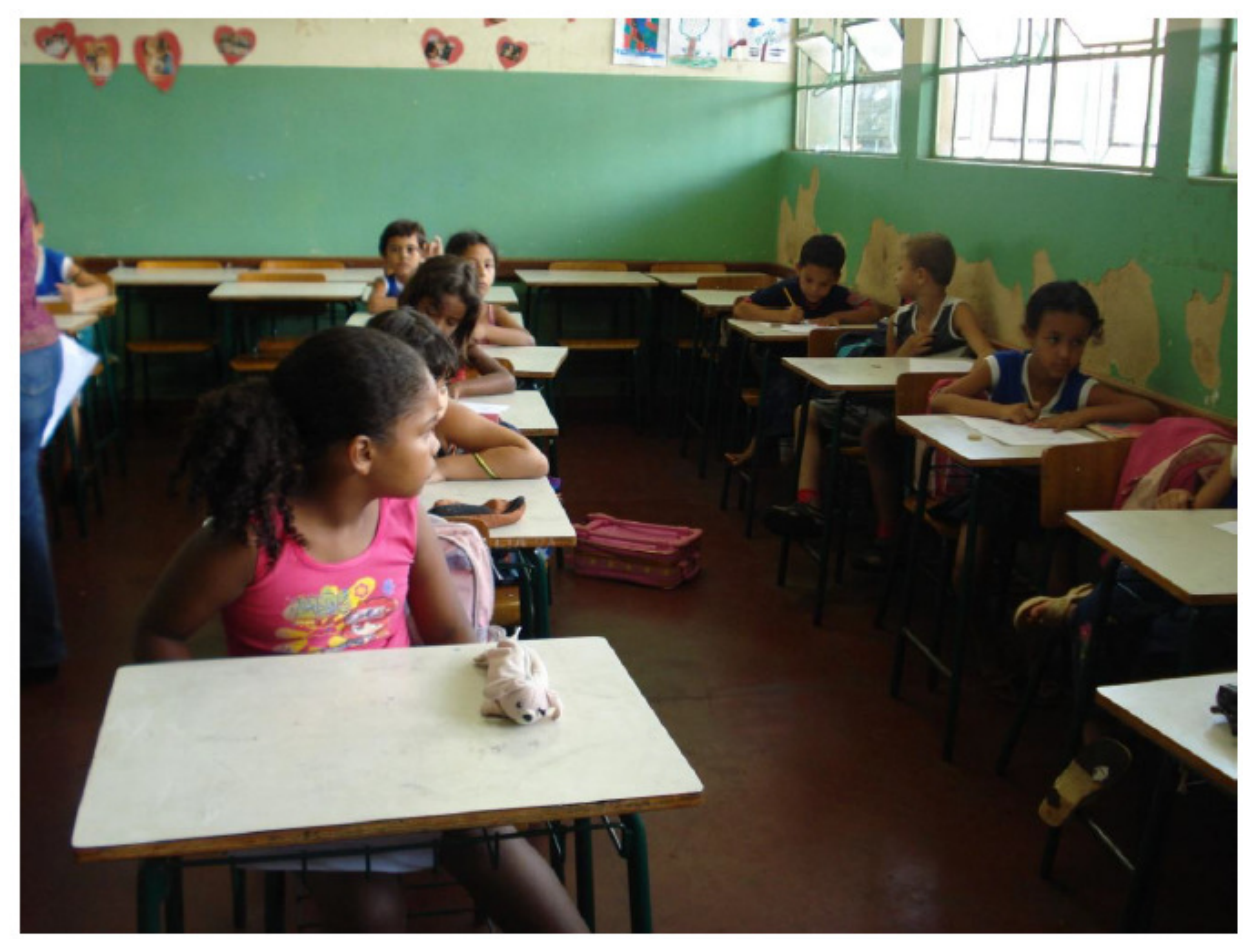

Figura 23. Crianças realizando avaliação externa.

Fonte: Costa (2009), p. 120. 
Esta avaliação, além de quantificar os resultados da escola, apresentava os resultados individuais de cada aluno. A pesquisadora mostra que estes resultados eram fixados na escola, como se observa na Figura 24.
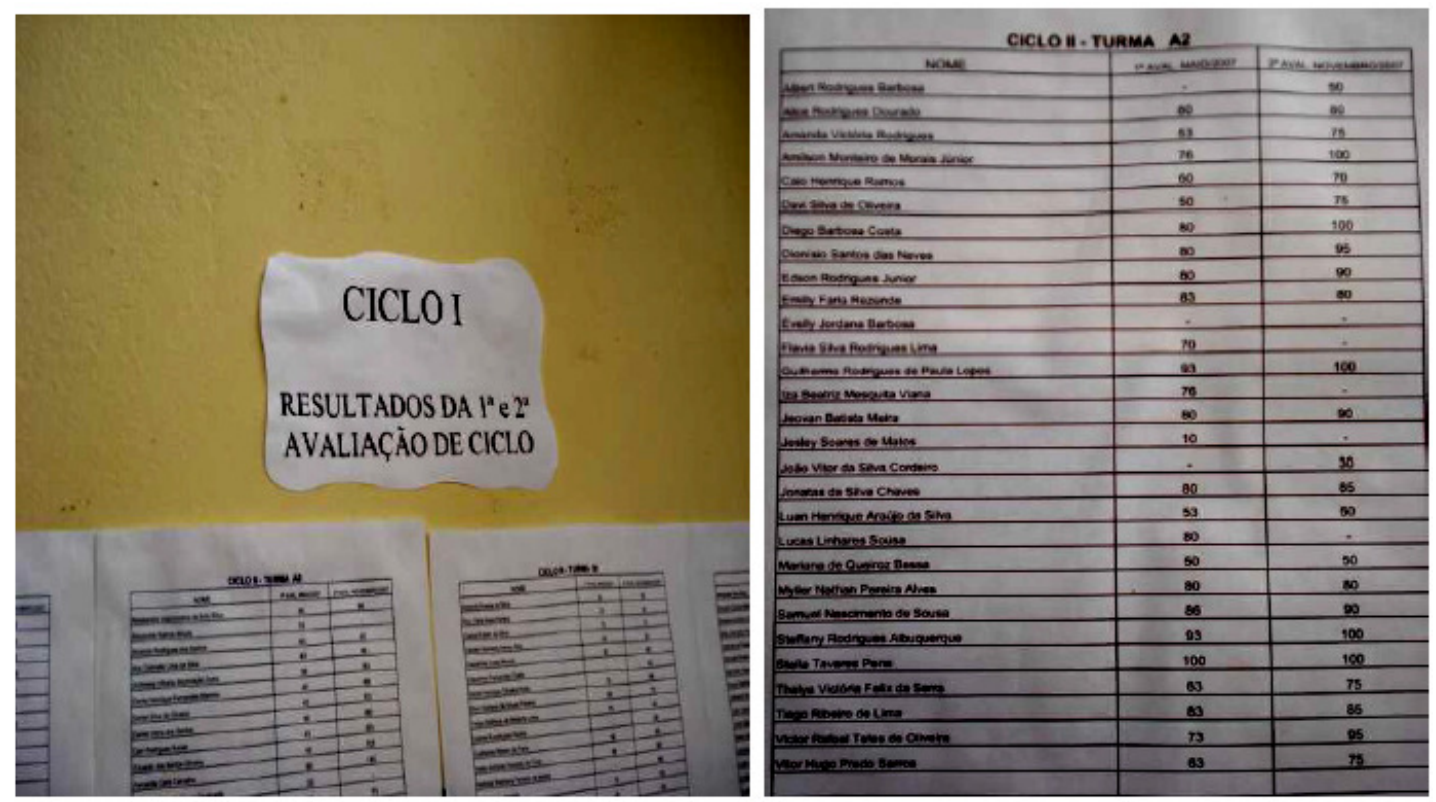

Figura 24. Mural de resultados das avaliações externas com as crianças de seis anos.

Fonte: Costa (2009), p. 123.

A prática observada na Figura 24 contribui para a responsabilização do aluno por seu desempenho escolar. Expor uma nota ou resultado de um teste é expor o aluno, e vai contra os direitos infantis estabelecidos pelo ECA - Estatuto da Criança e do Adolescente, como o direito à preservação da identidade. Esta prática pode gerar constrangimentos ao aluno e em nada contribui para o processo de ensino-aprendizagem.

Dessa forma, observa-se que neste contexto investigado por Costa (2009) não houve o rompimento com os modelos classificatórios de avaliação, que passaram a ser impostos também às crianças de seis anos. Uma professora entrevistada pela pesquisadora aponta que as avaliações acabam por responsabilizar o próprio aluno por seu mau desempenho:

Pois é, eu acho assim, outro nó da escola é a avaliação, não é dessa escola, do sistema educacional em si é a avaliação e eu acho que às vezes se torna mais fácil se avaliar o menino, você se afasta mais, você delega mais responsabilidades, né? Se eu dei uma prova e a maioria tirou três e uns dois tiraram nota mais acima, de quem é a responsabilidade? Da turma! Muito pouco ou raramente o profissional se curva diante disso e diz o problema pode estar em mim. Por que é a maioria, então eu acho assim eu acho que 
essa questão de colocar uma prova, uma nota, não sei qual é o objetivo da secretaria (COSTA, 2009, p. 121).

A fala desta professora exprime sua crítica em relação ao processo avaliativo realizado na escola e elaborado pela Secretaria Municipal de Educação. Para ela, é preciso rever as práticas de avaliação, rompendo com as práticas classificatórias de dar notas aos alunos. Se o objetivo com esta avaliação é apenas uma sondagem para dados da Secretaria Municipal de Educação, de fato, parece não haver sentido em quantificar o desempenho dos alunos e expor suas notas nos murais da escola. Dessa forma, acredita-se que

a avaliação descritiva, investigativa, diagnóstica, processual, contínua, dinâmica e qualitativa é suficiente para que haja a análise do processo de aprendizagem do aluno e pode indicar os problemas que precisam ser resolvidos, sendo assim a quantificação torna-se desnecessária (COSTA, 2009, p. 122).

Segundo a pesquisadora, apesar das divergências entre os professores sobre a necessidade de haver ou não provas específicas para conhecerem o nível de aprendizado dos alunos, todos foram unânimes em afirmar que a avaliação deve ter como objetivo a compreensão por parte do professor e da escola sobre como está o processo educativo, quais as dificuldades apresentadas e com base nessas avaliações repensar a escola.

Conforme afirma a autora, segundo os professores entrevistados o retorno desta avaliação elaborada pela SME surge em forma de cobranças:

eles têm dado a devolutiva pra escola e junto dessa devolutiva tem as cobranças, que os alunos não estão aprendendo que os professores precisam trabalhar mais com esses alunos, que precisa ser trabalhado também individualmente (COSTA, 2009, p. 124).

Assim, esta forma de avaliação, além de reforçar e disseminar as práticas classificatórias dos alunos e responsabilizá-los por seu desempenho, exerce uma pressão indireta sobre o professor, que muitas vezes acaba por direcionar seu trabalho com as crianças de seis anos ao ensino dos conteúdos e conhecimentos que são pedidos na avaliação.

Correa (2010), em pesquisa no interior de São Paulo, mostra que a Secretaria Municipal de Educação elaborou fichas de acompanhamento individual dos alunos e discute alguns problemas evidenciados com esta prática. Na percepção das professoras entrevistadas, essa ficha é muito extensa e exige um nível de detalhamento que, além de tomar tempo demais para o preenchimento, não condiz com a realidade do trabalho realizado. A fala de uma delas evidencia esta percepção: 
Agora, uma coisa assim, absuurrrda, é a ficha de avaliação! É uma coisa inviável. Todo mundo já deu sugestões pra sintetizar, porque aquilo é... Ela não é prática, nem pra nós nem para os pais! A impressão que eu tenho é que é um trabalho inútil, em vão, e isso dói, sabe, isso dói (CORREA, 2010, p. $322)$.

Segundo a autora, a ficha abordava cinco áreas do conhecimento, 17 tópicos, e 95 aspectos a serem observados no conjunto das áreas. Apesar disso, a autora verificou ao analisar o conteúdo da ficha que a alfabetização é privilegiada:

na área "língua e linguagem", além do detalhamento sobre diversas capacidades a serem observadas, há um quadro específico em que as professoras devem informar o "nível" de aprendizagem da escrita, classificando as crianças em pré-silábicos, silábicos, silábico-alfabéticos e alfabéticos, e o nível de aprendizagem da leitura (não reconhece letras e sílabas; reconhece letras e sílabas isoladamente; lê sílabas simples; lê sílabas compostas; lê textos sem entendimento; lê textos com entendimento) (CORREA, 2010, p. 323).

No entanto, a autora verificou que além das fichas de acompanhamento, a SME manteve o seu sistema de avaliação externa que existia antes do ensino fundamental de nove anos. Assim, a autora aponta para uma incoerência entre as orientações dadas aos professores, o conteúdo das fichas de acompanhamento, e o conteúdo solicitado nas provas de avaliação externa. O questionamento de uma das professoras entrevistadas evidencia esta incoerência:

Ela [a avaliação externa] tá mais para o tradicional do que para o construtivismo da ficha! Ela é uma avaliação praticamente tradicional. Eles dão 'problema' como dava antigamente! Então, quer que a gente modernize o trabalho, mas, o pedido na prova é uma conta!? (CORREA, 2010, p. 323).

Segundo a autora, embora não houvesse um ranqueamento explícito dos resultados da avaliação externa da SME, esta forma de avaliação contribui para a diferenciação entre as escolas, e para "a disseminação e o reforço da lógica segundo a qual a responsabilidade por aquilo que seria um “bom” resultado é do professor e do aluno” (CORREA, 2010, p. 324, grifo nosso). Além disso, conforme verificou a pesquisadora, em nenhum momento durante a realização da pesquisa (que ocorreu de 2008 a 2010) foram estabelecidos instrumentos para avaliar as condições de oferta do ensino e, mesmo tecendo algumas críticas, as professoras não relacionaram os resultados obtidos por suas turmas à falta dessas condições.

Na pesquisa de Moro (2009) os professores também mencionaram a ficha avaliativa elaborada pela SME de Curitiba (PR) para ser preenchida pelos professores para cada aluno. A autora verificou que, para os docentes, esta ficha exerce uma cobrança quanto aos 
conteúdos que devem trabalhar com as turmas de seis anos, como afirma uma das professoras entrevistadas:

[...] eu estou sentindo que há uma cobrança maior. Você vê pelos conteúdos que você tem que trabalhar, pela própria ficha de avaliação que você tem que preencher... tem a questão primeiro da oralidade, daí tem da leitura e da escrita, mas a representação da escrita no início é através de desenhos [...] agora no final do ano [...] Aparece até se a criança consegue ler pequenos textos (MORO, 2009, p. 234).

Segundo a autora, estas cobranças surgiam também com outras formas de avaliação externa, como a Provinha Brasil, que deve ser aplicada aos egressos do primeiro ano. A fala das professoras entrevistadas (professoras de turmas primeiro ano) evidencia o quanto a Provinha Brasil preocupa os professores e gestores:

[...] esse ano os meus alunos, os nossos alunos que eram do primeiro ano, [...] ano passado [...] fizeram a Provinha Brasil. Então... lógico que muitas coisas que tinham lá eles não sabiam fazer... [...] há uma grande preocupação assim, tanto da Secretaria Municipal da Educação quanto do Núcleo Regional de Educação, da própria escola, assim, que está tendo uma cobrança maior esse ano por conta disso. [...] aqui na escola a equipe administrativa e pedagógica... Fez com a gente uma avaliação sobre essa avaliação, [...] nós conversamos muito sobre isso. É... Depois nós tivemos um seminário, que eu participei também, promovido pela Secretaria Municipal de Educação, sobre como que foi esse ranking mesmo, das escolas, do desempenho. [...] O que é que faltou para os nossos alunos e o que deveria então... ser trabalhado mais, [...] e a gente até chegou à conclusão de que nossos alunos precisam ter mais contato com livros... (FERNANDA)

[...] eu fiquei sabendo que a nossa escola ficou em nível dois. Aí eu fui procurar saber se isso era bom ou se isso era ruim. Aí, parei para pensar que no ano que vem é essa turminha que eu estou que vai estar prestando essa Provinha. E foi uma coisa que me preocupou bastante. (BEATRIZ) (MORO, 2009, p. 234-235).

Dessa forma, observa-se que a Provinha Brasil, por estabelecer o ranqueamento das escolas, acaba influenciando e direcionando o trabalho docente. Para Klein (2011), essa influência não ocorre somente no trabalho do professor, mas também em toda a política educacional, que se baseia nos resultados destas avaliações externas. Em pesquisa realizada na rede municipal da capital paulista, a autora verificou nos documentos municipais emitidos pela SME que o objetivo estabelecido para a rede municipal era "assegurar um trabalho educacional voltado para a melhoria das condições de desenvolvimento dos alunos, bem como dos resultados de suas aprendizagens, medidos pelas 'Prova São Paulo', 'Prova Brasil' e 'IDEB'” (KLEIN, 2011, p. 104, grifo no original). Dessa forma, segundo a autora, 
pode-se afirmar que "as avaliações externas e seus resultados passaram a nortear a política educacional da rede municipal e exerceriam grande força na definição dos currículos e das práticas pedagógicas" (p. 104).

Portanto, observa-se que o sistema nacional de avaliação, de caráter classificatório e baseado no desempenho dos estudantes em testes padronizados, responsabiliza o aluno e o professor pelo resultado alcançado e não leva em conta o capital cultural das crianças e jovens bem como as condições da oferta de ensino. No entanto, cada vez mais vemos políticas públicas que são propostas com base nos resultados destas avaliações. O ensino é mais valorizado pelos seus resultados do que pelos processos, e os currículos escolares acabam sendo direcionados de acordo com os conteúdos dos testes nacionais.

Além disso, os resultados das avaliações externas muitas vezes não refletem a realidade observada nas escolas. Elaboradas de forma padronizada a todos os alunos, as avaliações externas desconsideram os projetos de cada escola e suas realidades particulares. Essa situação foi expressa na fala de uma professora de primeiro ano entrevistada por Lima (2011), em pesquisa realizada em Juiz de Fora com professores da rede municipal de ensino, transcrita a seguir:

[...] o fazer essas provas em si já é uma situação diferente do real da escola. O formato da prova é diferente, a aplicação muda, os conteúdos, os objetivos da avaliação... Por mais que a escola tente atenuar esse impacto, essa ansiedade, isso acaba interferindo nos resultados. Os alunos não estão acostumados em fazer provas com esse formato. Os textos, por exemplo, são grandes. As provas são grandes e cansativas. São muitas as interferências que podem influenciar os resultados (p. 150).

Portanto, observa-se que as avaliações externas pouco medem, de fato, sobre a aprendizagem dos alunos, por ser uma prova padronizada que muitas vezes não reflete a realidade das escolas, e pelos diversos fatores que podem influenciar em seus resultados, como por exemplo, a ansiedade das crianças no dia da prova.

A pesquisa de Abreu (2009) apresenta interessante situação em que se observa claramente como os processos avaliativos muitas vezes não refletem os conhecimentos da criança. Durante a realização de observação na escola, a mãe de uma criança do terceiro ano veio procurar a professora para conversar sobre uma prova que a professora havia dado aos alunos: 
É que eu queria conversar sobre essa prova com ela. Eu só não entendo o que acontece com esse menino. Veja só, nós temos um comércio e ele ajuda eu e o pai dele no caixa do mercado o dia todo. Ele recebe dinheiro, dá o troco para os fregueses, anota quanto de dinheiro entrou, quanto saiu, tudo direitinho. Aí chega na hora da prova ele não consegue ler os probleminhas, fazer as contas e colocar a resposta certa (ABREU, 2009, p. 95).

Dessa forma, situações como essas são claros indícios de que o processo de avaliação é algo bem mais complexo do que aplicar uma prova padronizada a todas as crianças.

Associada à questão da avaliação, encontra-se a questão da reprovação. Como discutido no Capítulo II do presente trabalho, os documentos do Ministério da Educação orientam para a não reprovação dos alunos no primeiro ano do ensino fundamental. Porém, como já discutido anteriormente, este índice tem aumentado cada vez mais, sendo possível questionar se as orientações do MEC estão sendo levadas em consideração na implementação do ensino fundamental de nove anos.

Dados da pesquisa desenvolvida por Araújo (2008) reforçam este argumento. Em pesquisa realizada com quatro professoras de primeiro ano da rede municipal de Juiz de Fora (MG), a pesquisadora verificou que o que mobilizava uma das professoras a modificar seu trabalho com as crianças de seis anos não eram as orientações do MEC, e sim as cobranças: dos pais dos alunos, do governo frente às avaliações externas, mas, acima de tudo, da outra escola que receberia seus alunos no segundo ano. A professora relatou: "me sinto pressionada a dar mais coisas, a alfabetizar, porque a escola do Estado está reprovando os alunos" (ARAÚJO, 2008, p. 84).

Segundo as professoras, esta escola era da rede estadual de ensino, e ao receber os alunos provindos da escola que lecionavam, avaliava o nível de alfabetização das crianças para, a partir disso, "definir quais crianças deveriam fazer novamente o primeiro ano e as que deveriam seguir para o $2^{\circ}$ ano" (ARAÚJO, 2008, p. 83). A pesquisadora verificou que essa era uma questão polêmica e que, segundo a escola, a Secretaria de Educação de Minas Gerais já estava tomando providências.

Como discutido anteriormente, as pesquisas analisadas mostram que com a ampliação do ensino fundamental as cobranças e exigências para as crianças de seis anos são maiores, uma vez que passaram a serem inseridas no modelo do ensino fundamental. A pesquisa de Zingarelli (2009), realizada em duas escolas privadas e duas municipais de Araraquara (SP), verificou que os alunos eram avaliados individualmente de forma processual, e que "os alunos que apresentam dificuldades contam com aulas de reforço escolar para sanar as dificuldades 
apresentadas" (p. 93). Assim, observa-se uma cobrança por bons desempenhos dos alunos, chegando ao ponto de implementar já para as crianças de seis anos a prática de aulas de reforço, responsabilizando o aluno por seu mau desempenho.

Antes de finalizar as considerações sobre a questão da avaliação, ressalta-se que este contexto de cobranças e exigências por melhores resultados impactam também no cotidiano escolar das crianças de primeiro ano. Inseridas em contexto de constante avaliação do seu desempenho, elas demonstram sentir ansiedade e medo.

As pesquisas de Costa (2009) e Abreu (2010) mostram que as crianças não gostam de errar. Segundo Costa (2009), em diversos momentos durante as observações, "várias crianças se mostravam angustiadas e com medo de errarem ou de não aprenderem a escrever" (p. 146). A autora cita uma cena de seu diário de campo:

Luna estava chorando, fui até ela e perguntei o porquê do choro. Ela disse que era porque não sabia fazer a tarefa. Mostrou-me a palavra "canetacaixa", eu lhe disse para mostrar para a professora e ela disse: "eu mostrei, tá errado e eu não sei como escrever! [...]

Luna estava angustiada e procurava a ajuda da professora, mas ela estava ocupada em ensinar a tarefa à outra criança (COSTA, 2009, p. 146).

A pesquisa de Abreu (2010) também mostra que as crianças não gostam de errar e se sentem tristes quando a professora aponta que as atividades não foram realizadas de forma satisfatória para ela. Uma das crianças participantes da pesquisa afirmou:

Inês: (...) a gente gosta mais sabe de quê? De vir pra brincar, porque tia disse que a gente não faz muito bem [as atividades em sala de aula], e a gente fica tão, tão triste...

$[\ldots]$

Inês: Tia diz: 'Faz mais! Tá errado aqui!' A gente apaga, não faz mais, joga o caderno pra lá porque a gente acha ruim (ABREU, 2010, p. 63-64).

Estas falas das crianças são importantes de serem ressaltadas na discussão sobre os processos avaliativos. Para Costa (2009), "a história da educação está marcada por um tipo de avaliação que consiste em um ritual que serve, na maioria das vezes, como forma de poder, de opressão e é causa de dor, medo, angústia e sofrimento para o aluno" (p. 123). Frente à demonstração de sentimentos de ansiedade, medo e tristeza das crianças, torna-se urgente e necessário rever os processos avaliativos e demais práticas que associam o aluno ao seu desempenho. 


\subsubsection{Breves considerações sobre os efeitos da ampliação do ensino fundamental sobre o} currículo e práticas pedagógicas da Educação Infantil.

A ampliação do ensino fundamental para nove anos e sua proposta de reelaboração de currículo para as crianças de seis anos acabam por exigir que o currículo dos demais anos do ensino fundamental e também da educação infantil sejam revistos para que o trabalho desenvolvido nestas etapas seja contínuo e integrado.

No entanto, Rosa (2011) e Correa (2011) apontam que pouca atenção tem sido dada à Educação Infantil com a implantação do ensino fundamental de nove anos. O estudo de Rosa (2011) teve por objetivo analisar as opções políticas e práticas que influenciaram a definição de gestão das políticas de educação infantil nos municípios, a partir da implantação do ensino fundamental de nove anos. O campo empírico da pesquisa compreendeu três municípios da região sul do Brasil: Frederico Westphalen (RS), Chapecó (SC) e Pato Branco (PR). Foi realizada pesquisa documental, envio de questionários com os secretários municipais de educação, e entrevistas com dirigentes municipais de educação e um profissional da educação infantil de cada município. A partir desta investigação, a autora afirma que foi possível perceber que "a preocupação tem recaído mais especificamente sobre o ensino fundamental, e com menor expressão sobre a educação infantil e seus velhos e novos dilemas" (ROSA, 2011, p. 126).

Conforme afirma a autora, o estudo verificou que, mesmo diante da implantação do ensino fundamental de nove anos, que altera e afeta também a educação infantil, não há uma política municipal de educação infantil com objetivos claros e normas específicas locais para atender a realidade educacional de cada um dos municípios estudados (ROSA, 2011). Segundo a autora, "prevalece o entendimento entre os municípios de que a alteração nas condições para a educação das crianças até 5 anos está mais diretamente relacionada a uma questão organizacional, demarcada basicamente pela alteração da faixa etária atendida" (ROSA, 2011, p. 126). Em outras palavras, verificou-se a compreensão de que a ampliação do ensino fundamental apenas alterou a organização da educação infantil quanto à faixa etária atendida.

O estudo de Correa (2011a) analisou o processo de ampliação do ensino fundamental e seus reflexos sobre a educação infantil com base em resultados de pesquisa realizada em duas escolas de ensino fundamental e em uma escola de educação infantil de um sistema municipal 
de ensino no interior do Estado de São Paulo. Os resultados indicaram que os professores da educação infantil ficaram à margem do processo de reorganização do ensino, tendo tomado conhecimento da ampliação do ensino fundamental para nove anos apenas ao final do primeiro ano de implantação, que ocorreu em 2007. Na educação infantil observou-se um aumento na preocupação em preparar as crianças para alfabetização:

Entre as turmas de crianças com 5 anos de idade, observamos a intensificação de lições de casa e sua correção em classe, com a professora registrando as "respostas" na lousa e as crianças refazendo em suas folhas xerocadas ou cadernos, numa clara reprodução da organização do trabalho com alunos do ensino fundamental (CORREA, 2011a, p. 113).

Segundo a autora, o estudo permitiu constatar que atividades como cópia de letras e números vêm ocorrendo de forma cada vez mais intensa, sob o argumento de que, com o ingresso das crianças de seis anos no ensino fundamental, uma preparação das crianças de cinco anos seria ainda mais necessária. A partir destes resultados, a autora analisa que "a ampliação do ensino fundamental no município, da forma como vem se realizando, tem se refletido negativamente sobre a organização pedagógica da educação infantil” (p.105).

Além de Correa (2011a), outros pesquisadores como Hashimoto (2012), Portella e Hickel (2010) e Zingarelli (2009) reportam este aumento na preocupação em preparar as crianças da Educação Infantil para a alfabetização. A pesquisa de Hashimoto (2012) buscou investigar em que medida os instrumentos legais ofereceram subsídios à mudança da criança de seis anos para o ensino fundamental, como essa mudança foi vivenciada por professores e gestores, e quais foram os encaminhamentos sugeridos para o trabalho com esse primeiro ano. Este trabalho ocorreu em um município que dista $100 \mathrm{~km}$ da cidade de São Paulo, em uma escola particular e quatro escolas municipais, com observações de campo e entrevistas com quatro professores de primeiro ano e três gestores escolares. Sobre a implantação do ensino fundamental de nove anos, uma gestora entrevistada revela que:

[...] na verdade, o nível 2 sentiu mais, porque essas crianças estão tendo que tomar contato com uma coisa que até então elas não tinham

[...] é mais pesado aí, no segundo semestre, eles estão tomando contato praticamente diário com a bendita letra cursiva, porque é cobrado isso no primeiro ano e antes não tinha (HASHIMOTO, 2012, p. 133).

Segundo Hashimoto (2012), o "nível 2" a que a gestora se refere em sua fala se tratava de uma nomenclatura da escola para o trabalho com as crianças de cinco anos. A partir desta fala é possível inferir que nesta escola houve uma maior preocupação em introduzir alguns conteúdos para as crianças da Educação Infantil para prepará-las para o que é cobrado no $1^{\circ}$ 
ano do ensino fundamental. Em outro momento, a mesma gestora afirma que para preparar a criança para que o $1^{\circ}$ não lhe seja "traumatizante", a escola introduziu a prática de enviar lição de casa também para as crianças da Educação Infantil:

[...] não adianta a gente querer massacrá-los e aí a escola terá uma coisa maçante. Porque é a idade em que eles vão se traumatizar ou não [...] Então nesse ano, a gente visou a essa necessidade, e vamos tentar fazer uma coisa nova, que é mandar lição pra casa, entendeu? Se vão dar certas as benditas tarefinhas de casa, não sei [...] Mas eu acho que é uma questão de eles se sentirem mais importantes, uma vez que um bem pequenininho está saindo com a tarefinha de casa [...] eu acho que é o caminho. Vamos aproveitar que eles gostam muito, que não têm resistência nenhuma de fazer a tarefa, então vamos aproveitar agora pra ver se a gente consegue caminhar cada vez melhor, né? (HASHIMOTO, 2012, p. 148).

Conforme esclarece Hashimoto (2012), o "infantil" a que se refere a gestora são as crianças de três anos de idade. Para a pesquisadora, seu discurso transparece uma intenção de introduzir para essas crianças as obrigações a que as crianças de seis anos são submetidas; é trazer o modelo do ensino fundamental para a educação infantil.

O estudo de Portella e Hickel (2010) aponta, ainda, que os pais também apresentam esta preocupação em preparar a criança da Educação Infantil para a alfabetização e o ensino fundamental. Visando tecer interlocuções teóricas sobre a Psicopedagogia em suas interfaces com Educação, as autoras buscaram conhecer a visão de psicopedagogas, inseridas no cotidiano escolar das redes privadas e públicas, sobre o ensino fundamental de nove anos, e para tal realizaram entrevistas com cinco profissionais de Porto Alegre (RS). Uma das psicopedagogas entrevistadas afirmou que, preocupados com o desempenho de seus filhos no primeiro ano, os pais cobram para que a alfabetização comece na Educação Infantil: "os pais (educação infantil) cobram dos professores trabalhos de alfabetização que prepare a criança para fazer uma primeira série com menos dificuldades" (PORTELLA e HICKEL, 2010, p. $382)$.

Jacomini, Rosa e Alencar (2012), em estudo que envolveu professores, gestores, alunos e familiares de Diadema (SP), afirmam que a maioria dos pais participantes da pesquisa "disse ter preferência por matricular os filhos no Ensino Fundamental, pois concebem a Educação Infantil como um espaço somente de brincadeira, que não traz benefícios ao desenvolvimento de seus filhos" (p. 236). Os autores afirmam ainda que esta visão dos pais e familiares, compartilhada por muitos professores, gestores e outros profissionais da educação, expressa uma valorização da aprendizagem da leitura e da escrita, 
que tem resultado em uma pressão para que as crianças sejam alfabetizadas cada vez mais cedo.

Sobre este movimento de aceleração da alfabetização, intensificado com a implantação do ensino fundamental de nove anos, Jacomini, Rosa e Alencar (2012) fazem uma importante ressalva:

Embora seja importante essa valorização da aprendizagem da leitura e da escrita, é importante destacar que essa pressão para que as crianças sejam alfabetizadas cada vez mais cedo, em detrimento dos espaços e tempos de brincar, pode significar um desrespeito à infância e aos direitos das crianças pequenas (p. 236-237).

Assim, o que se torna problemático não é a preocupação em preparar a criança da Educação Infantil para o trabalho de alfabetização, mas a forma com que se busca preparar estas crianças (CORREA, 2011). A atenção voltou-se para a preparação das crianças da Educação Infantil para as cobranças e exigências que existirão no ensino fundamental. Com isso, diminuem-se os espaços e tempos destinados ao brincar, ficando ameaçada a garantia das necessidades e dos direitos das crianças. Como afirma Correa (2011),

[...] a questão é o conteúdo que se tem tomado como referência para desenvolver aquilo que está sendo compreendido como preparação.

Na realidade, o que observamos é uma antecipação, no sentido de se "fazer antes do tempo", de atividades que mesmo no EF [ensino fundamental], quando as crianças aí ingressavam com 7 anos, já eram consideradas inadequadas" (CORREA, 2011, p. 114).

Diante dos resultados preconizados pelas pesquisas analisadas, observa-se, portanto, que pouco se alterou do modelo tradicional do ensino fundamental com a ampliação desta etapa para nove anos, e que cada vez mais elementos deste modelo têm sido trazidos para a Educação Infantil. Estas observações cabem também para as crianças de seis anos, que perderam a oportunidade de vivenciar os espaços e tempos da Educação Infantil, para ingressar no Ensino Fundamental.

3.3.6 Novo currículo, novas concepções e novas práticas: construções possíveis.

Neste tópico pretende-se expor dados das pesquisas analisadas nesta revisão que permitem inferir alguns caminhos e possibilidades para construir melhorias na qualidade da 
educação neste contexto do ensino fundamental de nove anos, a despeito de todos os problemas, tensões, conflitos e dificuldades aqui já relatadas.

Primeiramente, apresenta-se aqui a pesquisa de Vargas (2010), que mostra o relato de uma docente que modificou sua prática pedagógica, buscando abandonar práticas tradicionais de alfabetização que realizava. Esta pesquisa objetivou investigar as concepções construídas frente às infâncias e às práticas lúdicas, ao longo da trajetória de vida pessoal e profissional dos docentes, perante a ampliação do Ensino Fundamental. Para isso, foram realizadas entrevistas com três professoras de primeiro ano, em Santa Maria (RS). Segundo Vargas (2010), as três colaboradoras da pesquisa transformaram suas práticas perante a ampliação do Ensino Fundamental, especialmente no que diz respeito a inserção do lúdico, mesmo a escola não tendo transformado sua estrutura e organização.

Destaca-se, no entanto, o trabalho de uma das professoras, em que foram observadas mudanças que iam além da inserção do lúdico: mudanças de concepções e práticas pedagógicas. Conforme informa Vargas (2010), esta professora trabalhou com alfabetização ao longo de 13 anos desde o início de sua carreira. Depois disso, trabalhou com outras séries, e em 2008 começou a trabalhar com o primeiro ano do ensino fundamental de nove anos. Ao voltar a lecionar para os primeiros anos do ensino fundamental, a professora reelaborou suas práticas de ensino incorporando atividades lúdicas com os conhecimentos que tinha como alfabetizadora. Questionada se houve mudanças em seu trabalho pedagógico, a professora afirmou:

É totalmente diferente, porque como eu te disse, as outras primeiras séries eram bem tradicionais né, eram bem o "BE A BÁ", o encher linha, cartilhas, a gente trabalhava em cima de cartilhas. E esse ano não, eu trabalho com o momento, com o que acontece; surgiu uma palavra, vamos supor, tu já aproveita aquela palavra ali; já vai tirando as letrinhas, as sílabas, o que dá pra montar. Então é do que surge, e antes a gente começava pelo alfabeto "à risca" de "A", a "Z", e esse ano, eu pelo menos não trabalhei assim né. É conforme vai acontecendo as coisas (VARGAS, 2010, p. 156).

Assim, a professora apropriou-se de seus conhecimentos como alfabetizadora para abandonar práticas tradicionais e trabalhar conforme seu próprio planejamento. Neste movimento de reelaborar suas práticas pedagógicas, a professora buscou materiais e atividades diversificadas e criativas, por meio de material reciclável, de cantigas, de histórias (VARGAS, 2010). Vale ressaltar ainda algumas informações fornecidas pela autora: esta professora não havia passado por curso de formação no momento da pesquisa, e suas únicas 
orientações foram que utilizasse o lúdico e que não haveria retenção dos alunos que não estivessem alfabetizados.

O estudo de Silva (2011) investigou a prática pedagógica de uma professora de primeiro ano, através de observações em sala de aula e entrevistas com a professora, em uma escola privada do município de Lajeado (RS). Defensora da abordagem do planejamento emergente, a pesquisadora escolheu essa professora por saber de seu trabalho diferenciado do modelo tradicional com o intuito de conhecer sua prática pedagógica e planejamento. A professora tinha experiência como professora alfabetizadora e também como professora na Educação Infantil.

Este trabalho revela uma possibilidade de rompimento com as práticas de planejamento "engessado", que não dão sentido nem aos alunos nem aos professores (SILVA, 2011). Segundo a autora, a professora utilizava em sua prática elementos presentes na Educação Infantil, como a organização da sala de aula em grupos e espaços, bem como a organização do ensino em projetos, abordados de forma lúdica para se trabalhar os conteúdos planejados. Em sua prática, estavam presentes atividades como construção de maquetes, esculturas e jogos pelas próprias crianças, teatro, atividade de desidratação de folhas, contação de histórias pela professora e pelas crianças, recorte, dobradura, desenho, pintura, modelagem, escrita de relatórios, construção de cartazes, trabalho com motricidade. A Figura 25 mostra fotos tiradas por Silva (2011) em momentos de realização de algumas destas atividades. 

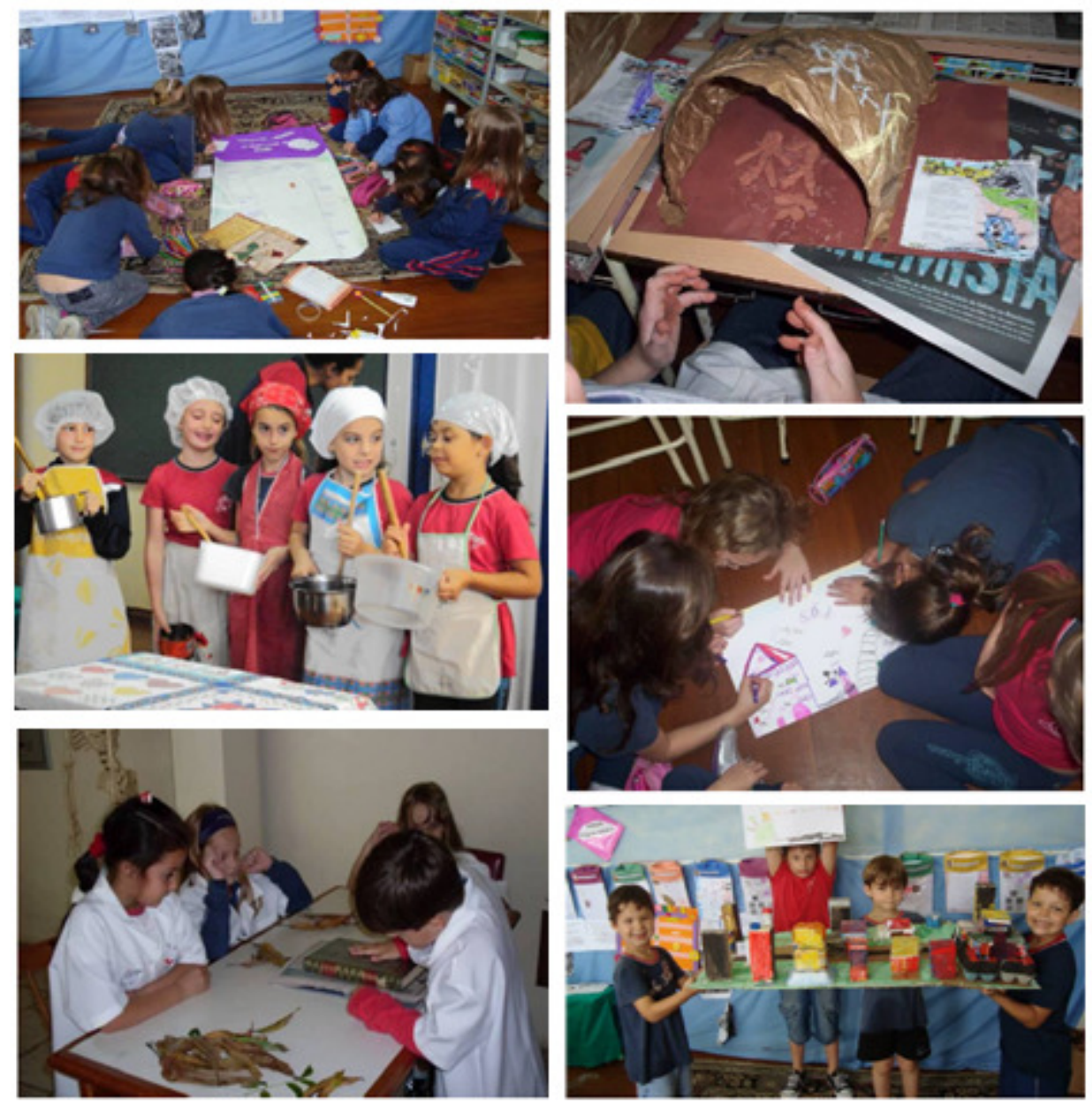

Figura 25. Turma de primeiro ano em diferentes atividades desenvolvidas por meio de projetos, descritos por Silva (2011).

Fonte: Silva (2011), pp. 148, 159, 163, 166, 169, 173.

A partir das fotos na Figura 25, é possível observar que as crianças têm diferentes vivências em seu cotidiano escolar, caracterizadas pela ludicidade e pela ampliação das possibilidades de expressão. Silva (2011) ressalta que o planejamento desta professora envolve também o ensino da leitura e da escrita, inseridos de forma contextualizada nos projetos e por meio de atividades como aquelas mostradas na Figura 25, garantindo às crianças um sentido a esta aprendizagem.

Segundo Silva (2011), na prática desta professora “o tempo é organizado, mas não regulado, em função do respeito ao ritmo de cada criança e das escolhas do grupo". Seu planejamento é realizado em conjunto com as crianças, sendo respaldado pela observação e escuta constante das crianças. Para a pesquisadora, a professora busca inovar a partir das sinalizações das crianças, construindo uma metodologia que leva em consideração os 
conhecimentos prévios das crianças, suas manifestações - falar, silenciar, brincar, olhar, e o universo da arte - cinema, literatura, arte, música, dança (SILVA, 2011).

Assim, os estudos de Vargas (2010) e Silva (2011) demonstram a importância da atuação do professor para a construção de novas práticas pedagógicas, quebrando com as práticas tradicionais que, retomando a fala de Correa (2011, p. 114), "mesmo no EF, quando as crianças aí ingressavam com 7 anos, já eram consideradas inadequadas".

Por fim, destaca-se a pesquisa realizada por Kishimoto, Pinazza, Morgado e Toyofuki (2011) na Escola de Aplicação da Faculdade de Educação da Universidade de São Paulo (Eafeusp), na capital paulista. A experiência vivida no Colégio de Aplicação se constitui uma situação diferenciada, mas Kishimoto et al. (2011) oferecem em seu artigo elementos importantes para discussão sobre a construção de um novo currículo e novas práticas de ensino. O estudo traz o relato de um trabalho colaborativo entre docentes da Escola de Aplicação e pesquisadores da Faculdade de Educação da Universidade de São Paulo (Feusp), visando à elaboração de um novo plano de ensino, delineado a partir de 2005, um ano antes da implantação do ensino fundamental de nove anos na Escola de Aplicação. Para esse propósito, foi buscado referencial teórico na literatura relacionada aos currículos e jogos e em duas produções do MEC, do final da década de 1990: Referencial Curricular Nacional para a Educação Infantil (RCNs) e Parâmetros Curriculares Nacionais para o Ensino Fundamental I (PCNs).

Segundo as autoras, o plano de ensino elaborado para o primeiro ano era fundamentado no lúdico e no letramento, permeados no trabalho do campo das linguagens, matemática e ciências naturais. Os conteúdos curriculares não foram fechados em disciplinas, mas desenvolvidos em "atividades relacionadas às linguagens integradas (artes visuais, música, teatro, literatura e expressão corporal) para que a criança possa ter contato com múltiplas referências culturais" (KISHIMOTO et al., 2011, p. 195). O Quadro 9 mostra como estavam organizadas essas atividades na rotina semanal do primeiro ano. 
Quadro 9: Rotina semanal do primeiro ano da Escola de Aplicação da Universidade de São Paulo.

\begin{tabular}{|c|c|c|c|c|c|}
\hline HORÁRIO & SEGUNDA & TERÇA & QUARTA & QUINTA & SEXTA \\
\hline $13 \mathrm{~h} 30-14 \nmid 00$ & $\begin{array}{l}\text { Rotina } \\
\text { Calendário } \\
\text { Chamada/ } \\
\text { Crachás } \\
\text { Lição de casa }\end{array}$ & $\begin{array}{l}\text { Rotina } \\
\text { Calendário } \\
\text { Chamadal } \\
\text { Crachás } \\
\text { Lição de casa }\end{array}$ & $\begin{array}{l}\text { Rotina } \\
\text { Calendário } \\
\text { Chamadal } \\
\text { Crachás } \\
\text { Lição de casa }\end{array}$ & $\begin{array}{l}\text { Rotina } \\
\text { Calendário } \\
\text { Chamada/ } \\
\text { Crachás } \\
\text { Lição de casa }\end{array}$ & $\begin{array}{l}\text { Rotina } \\
\text { Calendário } \\
\text { Chamada/ } \\
\text { Crachás } \\
\text { Liçä́o de casa }\end{array}$ \\
\hline $14 h 00-14 h 30$ & \multirow{2}{*}{$\begin{array}{l}\text { BIBLIOTECA } \\
\text {-Roda de } \\
\text { história } \\
\text {-Leitura } \\
\text { individual ou em } \\
\text { pequenos grupos } \\
\text {-Biblioteca } \\
\text { circulante }\end{array}$} & $\begin{array}{l}\text { CADERNO DE } \\
\text { PALAVRAS \& } \\
\text { HISTÓRIAS } \\
\text { (Leitura) }\end{array}$ & $\begin{array}{l}\text { RODA DE } \\
\text { HISTÓRIA }\end{array}$ & CANTORIA & \multirow[t]{2}{*}{ ARTE } \\
\hline $14 h 30-15 h 00$ & & $\begin{array}{l}\text { RODA DE } \\
\text { HISTÓRIA }\end{array}$ & $\begin{array}{l}\text { PASTA DE } \\
\text { LEITURA }\end{array}$ & HORTA & \\
\hline $15 \mathrm{~h} 00-15 \mathrm{~h} 30$ & RECREIO & RECREIO & RECREIO & RECREIO & RECREIO \\
\hline $15 \mathrm{~h} 30-16 \mathrm{~h} 00$ & $\begin{array}{l}\text { FOTOGRAFIA DA } \\
\text { PALAVRA } \\
\text { (Jogo) }\end{array}$ & \multirow[t]{2}{*}{ ARTE } & $\begin{array}{l}\text { VOCË SABIA? } \\
\text { Roda de novidades } \\
\text { e curiosidades }\end{array}$ & HORTA & $\begin{array}{l}\text { BIBLIOTECA } \\
\text { Roda de história } \\
\text { ou contadora } \\
\text { de história }\end{array}$ \\
\hline $16 \mathrm{~h} 00-16 \mathrm{~h} 30$ & \multirow{2}{*}{$\begin{array}{l}\text { EDUCAÇĀOO } \\
\text { FISICA }\end{array}$} & & \multirow{2}{*}{$\begin{array}{l}\text { EDUCAÇÃOO } \\
\text { FÍSICA }\end{array}$} & PARQUE & ESPAÇOS \\
\hline $16 \mathrm{~h} 30-17 \mathrm{~h} 00$ & & PARQUE & & \multirow[b]{2}{*}{ PROJETO } & \\
\hline $17 \mathrm{~h} 00-17 \mathrm{~h} 30$ & $\begin{array}{l}\text { HISTÓRIA } \\
\text { MALUCA } \\
\text { (Texto coletivo) }\end{array}$ & \multirow[t]{2}{*}{ PROJETO } & \multirow[t]{2}{*}{$\begin{array}{l}\text { JOGO } \\
\text { MATEMÁTICO }\end{array}$} & & $\begin{array}{l}\text { JOGO DE } \\
\text { ALFABETIZAÇÃO }\end{array}$ \\
\hline $17 \mathrm{~h} 30-18 \mathrm{~h}, 00$ & ESPAÇOS & & & $\begin{array}{l}\text { RODA DE } \\
\text { HISTÓRIA }\end{array}$ & LIEA \\
\hline
\end{tabular}

Fonte: Kishimoto et al. (2011), p. 196.

Assim, se observa no Quadro 9 que a rotina das crianças não é fragmentada em disciplinas como comumente são organizados os currículos do ensino fundamental, mas sim organizada em momentos destinados a diferentes atividades em que são trabalhados projetos interdisciplinares. Como afirmam as autoras, nesta organização "o letramento e a integração das linguagens aparecem em todos os momentos da rotina: em atividades na biblioteca, na roda de história, na cantoria, nos jogos, na produção de texto coletivo, no tempo e espaço das artes, do movimento, nos momentos para cantar, escrever e ler músicas" (KISHIMOTO et al., 2011, p. 196-197). Assim, a organização curricular elaborada nesta experiência da Escola de Aplicação diverge do modelo vigente de fragmentação do conhecimento em disciplinas, e 
"afasta-se da postura de 'exclusividade da alfabetização', criticada pela lei 11.274" (KISHIMOTO et al., 2011, p. 205).

O trabalho de Kishimoto et al. (2011) descreve cada um destes momentos que compõem a rotina da turma de primeiro ano, fornecendo ao leitor elementos para a compreensão dos objetivos e atividades que cada momento envolvia, e ainda, de como o lúdico e o letramento estavam permeados nos diferentes momentos da rotina semanal. Sobre o trabalho realizado no desenvolvimento da leitura e escrita, as autoras esclarecem: "não se trata de cópia e reprodução de palavras, mas as crianças criam textos, a partir das palavras-chave, utilizando histórias canônicas ou não canônicas, ou ainda experiências vividas", a partir de situações geradas por meio de jogos com palavras (KISHIMOTO et al., 2011, p. 201).

As autoras pontuam também a importância de que sejam garantidas condições para a realização deste trabalho diferenciado, envolvendo a aquisição de jogos e brinquedos, a existência de espaços diferenciados como o parque, a biblioteca, a horta, a adequação do espaço físico para o tamanho das crianças e para o trabalho coletivo (cadeiras no tamanho adequado, mesas em formato de trapézio), e a preparação do corpo docente para que estejam cientes da importância do lúdico para o desenvolvimento do letramento. Conforme afirmam as autoras, a implantação do ensino fundamental de nove anos na Escola de Aplicação da Universidade de São Paulo procurou atender a esses condicionantes realizando as mudanças necessárias. Segundo elas, a disponibilidade e adequação dos recursos pedagógicos foram essenciais para o sucesso da proposta. Assim, apontam que "em tempos em que se discute a qualidade da educação, é imprescindível que as políticas públicas considerem a infraestrutura e a proporção adulto/criança como variáveis fundamentais" (KISHIMOTO et al., 2011, p. 203).

Por fim, pelo exposto até o momento, observa-se que é urgente a necessidade de repensar as práticas no ensino fundamental, repensar os currículos, repensar todo o modelo vigente nesta etapa de ensino, embasando-se na perspectiva de uma alfabetização mais significativa, sem que a curiosidade das crianças seja reprimida, e que seja garantido o seu direito de brincar. Como afirma um gestor escolar entrevistado por Almeida (2011), repensar o ensino fundamental se faz urgente, "pois enquanto não houver uma discussão sobre a cultura da EMEF, não haverá uma mudança real, obrigando assim a criança ter que se adaptar e não a escola se adequar" (p. 176).

As pesquisas de Silva (2011), Vargas (2010) e Kishimoto (2011) mostram que não há nada de errado em alfabetizar as crianças, quando isso é realizado mediante propostas 
pedagógicas contextualizadas e organizadas visando às necessidades e características das crianças de seis anos. Assim, estas pesquisas se constituem em promissores relatos sobre caminhos a serem seguidos na desafiante busca por uma educação de qualidade e, particularmente, na busca pela superação dos problemas e conflitos advindos da implantação do ensino fundamental de nove anos.

Buscou-se neste tópico discutir sobre o que as pesquisas mostram sobre o currículo do ensino fundamental de nove anos, abordando especialmente o primeiro ano, por ser este o objeto de discussão da maior parte dos estudos analisados. Vale ressaltar que este foi um tema bastante abordado pelas pesquisas na área, que trouxeram muitas contribuições para a reflexão sobre o currículo. Sem a intenção de esgotar este debate, apresentaram-se aqui os principais resultados dos estudos analisados, detendo-se na discussão daqueles pontos mais diretamente relacionados aos objetivos específicos desta pesquisa.

\section{$3.4 \mathrm{O}$ brincar no $\mathbf{1}^{\mathbf{0}}$ ano do ensino fundamental de nove anos: "brincar, só depois de estudar e para quem se comportar".}

No presente tópico pretende-se discutir os resultados das pesquisas sobre o brincar no ensino fundamental de nove anos. Conforme já descrito e discutido nos tópicos anteriores, as pesquisas mostraram que as escolas têm adquirido brinquedos para as crianças de seis anos, mas houve dificuldades em criar ambientes lúdicos, como o parque infantil. Viu-se também que o trabalho de alfabetização no primeiro ano não incorporou o lúdico, sendo realizado com práticas pedagógicas dissociadas do brincar e do elemento prazeroso que caracteriza a ludicidade. Ainda, as pesquisas apontaram para o conflito vivenciado pelos docentes de primeiro ano: como tornar o brincar presente no cotidiano e 'dar conta' das cobranças sobre a alfabetização? Diante destas questões, buscou-se, neste tópico, aprofundar esta temática e apresentar ainda outros resultados das pesquisas analisadas sobre o brincar no ensino fundamental de nove anos.

Estudos como Aguiar (2012), Almeida (2011), Boeno (2011) Brandão (2012), Gil (2012), Heinig (2010), Portella e Hickel (2010), Raniro (2009) Souza (2012) e Vargas (2010) ressaltam a presença de iniciativas e preocupação por parte de professores e gestores em inserir o brincar na rotina das crianças de seis anos no ensino fundamental. 
Brandão (2012) mostra em seu estudo, realizado em um colégio estadual de Porto Alegre (RS), por meio de observações da rotina escolar de uma turma de primeiro ano e entrevista com a professora da turma, que apesar de ter sido observado foco na alfabetização, foi possível observar também constantes iniciativas da professora em inserir o brincar na rotina da turma. Segundo Brandão (2012), todos os dias constava no planejamento da aula um momento para brincadeiras, que ocorria no pátio ou em sala de aula. A professora também levava brinquedos para a aula, mesmo de sua casa, e outros ela própria confeccionava. Como exemplo, Brandão (2012) cita o dia em que a professora levou um teclado para realizar atividades lúdicas com música durante a aula.

Outra importante iniciativa da professora é o "momento da fama": um momento em que cada aluno, individualmente ou em grupo, tem a oportunidade de fazer uma apresentação do que sabe ou gosta de fazer, sendo as próprias crianças que escolhem o gênero e estilo do que desejam apresentar. Brandão (2012) relata um desses momentos da turma, no qual uma aluna muito tímida apresentou-se cantando uma música em inglês, e surpreendeu a todos os amigos. Segundo a autora, em conversa com as crianças estas relataram adorar o "momento da fama”, gostar de brincar no parque, e gostar de brincar de massinha. Brandão (2012) comenta, ainda, que quando brincavam no pátio era permitido às crianças que desenhassem com giz nos muros. Para a autora, isso permitia que as crianças se apropriassem dos espaços da escola: "tiveram a possibilidade de deixar suas marcas na escola, identificando-se como sujeitos partícipes daquele lugar" (BRANDÃO, 2012, p. 87).

O estudo de Vargas (2010), realizado por meio de entrevistas com três professoras de primeiro ano, demonstra por meio das falas destas professoras que elas se preocuparam em inserir o brincar no trabalho com as crianças de seis anos. Segundo elas, o trabalho com o primeiro ano mudou muito do trabalho realizado com a antiga primeira série, por envolver o lúdico no cotidiano escolar e também no processo ensino-aprendizagem. Em seus depoimentos, é possível observar que o brincar é valorizado por estas professoras:

Eu considero muito importante pra aprendizagem, acho que é muito mais fácil aprender dessa maneira, de uma forma mais prazerosa para a criança e eu acho que ela vai aprender muito mais e vai lembrar mais com aquela atividade do que de outras formas, como a memorização. (Entrevista Marta)

E nas atividades mais dirigidas também o tema parte da ludicidade. Sempre que eu posso, eu trabalho com o brincar, e as brincadeiras não dirigidas, de imaginação. E eu observo muito, tem aqueles que não querem brincar, que não se inserem no grupo, aí a gente tem que começar a partir do que eles gostam. (Entrevista Joze) 
Uma preocupação como professora, eu sempre tenho, assim: - vamos brincar, vamos jogar, vamos conciliar isso da melhor maneira possível com coisas, que a gente chama coisas "sérias", entre aspas, porque o brincar não deixa de ser sério. O brincar é sério, as brincadeiras, as crianças vão trocando, tudo isso e sério. $\mathrm{O}$ trabalho em grupo, tudo isso é aprendizagem. E a gente tem esse olhar as vezes: - ah, que agora é a hora da brincadeira e depois a hora de... (Entrevista Joze) (VARGAS, 2010, p. 167-168).

Segundo Vargas (2010), esta valorização do lúdico pelas professoras é o fator principal para que elas se empenhem em realizar mudanças em seu trabalho com as crianças de forma a cada vez mais tornar o lúdico presente em cada atividade, permeando todo o processo de ensino-aprendizagem. "Quando a preocupação com o lúdico está entrelaçada com a crença na melhor aprendizagem do aluno e o respeito à infância, certamente os professores se instigam mais para a utilização desta perspectiva" (VARGAS, 2010, p. 167).

Assim, observa-se que as pesquisas analisadas indicam, em princípio, que o lúdico ocorre em diferentes momentos no cotidiano escolar das crianças de primeiro ano do ensino fundamental. Entretanto, a maioria dos estudos analisados revela também que apesar do brincar ser observado na rotina das crianças de seis anos, este ainda é pouco valorizado, ocorrendo de forma restrita a determinados momentos, e dissociado do ensino (ABREU, 2010, AMARAL, 2008; ALMEIDA, 2011; ANTUNES, 2010; ARAÚJO, 2008; ARELARO, JACOMINI E KLEIN, 2011; BARBOSA, 2009; BONAMIGO, 2010, BUENO, 2010; CAPUCHINHO, 2007; CARNEIRO, 2006; CORREA, 2010; CORREA, 2011; COSTA, 2009; DELFIN, 2012; DORNELLES, 2011; FONTES, 2009; FURTADO, 2009; JACOMINI, ROSA E ALENCAR, 2012; KLEIN, 2011; MALTA 2012; MARCONDES, 2012; MAREGA, 2010; MASCIOLI, 2011; MIRANDA, 2012; MORENO, 2012; MORO, 2009; MOYA, 2009; NOGUEIRA, 2011; NOGUEIRA E CATANANTE, 2011; RANIRO, 2009; ROCHA, 2009; ROCHA, 2012; SAMWAYS, 2012; SILVA, 2008; TENREIRO, 2011, ZINGARELLI, 2009), como se discutirá a seguir.

A pesquisa realizada por Marcondes (2012), visando compreender quais as continuidades e descontinuidades presentes na organização e nas práticas pedagógicas no momento de transição da educação infantil para o ensino fundamental de nove anos, realizou observações em quatro escolas, sendo dois Centros de Educação e Recreação (CER) e duas escolas de ensino fundamental do interior de São Paulo, durante um semestre na EI e um ano letivo no EF, além de entrevistas com responsáveis e professores e crianças. A pesquisa relata grande descontinuidade da educação infantil para o ensino fundamental em relação aos espaços, postura do professor e vivências do lúdico. Conforme afirma a autora, no ensino 
fundamental foi observado menor tempo destinado às atividades lúdicas, incluindo também poucos espaços lúdicos que pudessem ser explorados. O brincar ficou restrito às aulas de Educação Física, ao recreio e aos momentos disponibilizados pelas docentes ao final da aula (MARCONDES, 2012).

A pesquisa de Costa (2009) envolveu observações e análise do Projeto Político Pedagógico de uma escola de ensino fundamental da rede municipal de Goiânia (GO), além de análise documental local e nacional. O estudo mostra que em nível documental a valorização do lúdico por meio de brincadeiras e jogos se apresentou de forma crescente nas propostas da Secretaria Municipal de Educação, e se mostrou presente no Projeto Político Pedagógico da escola. No entanto, conforme afirma a autora, estes documentos apresentam a ludicidade e a brincadeira somente vinculadas à disciplina de Educação Física. As observações realizadas pela pesquisadora permitiram constatar que, em conformidade com as orientações nos documentos oficiais, as atividades lúdicas ocorreram principalmente nas aulas de Educação Física, consistindo principalmente em brincadeiras, no pátio ou na quadra da escola. A Figura 26 mostra o registro fotográfico feito por Costa (2009) de momentos de brincadeiras dirigidas realizadas com as crianças de seis anos no pátio e na quadra, durante aulas de Educação Física.
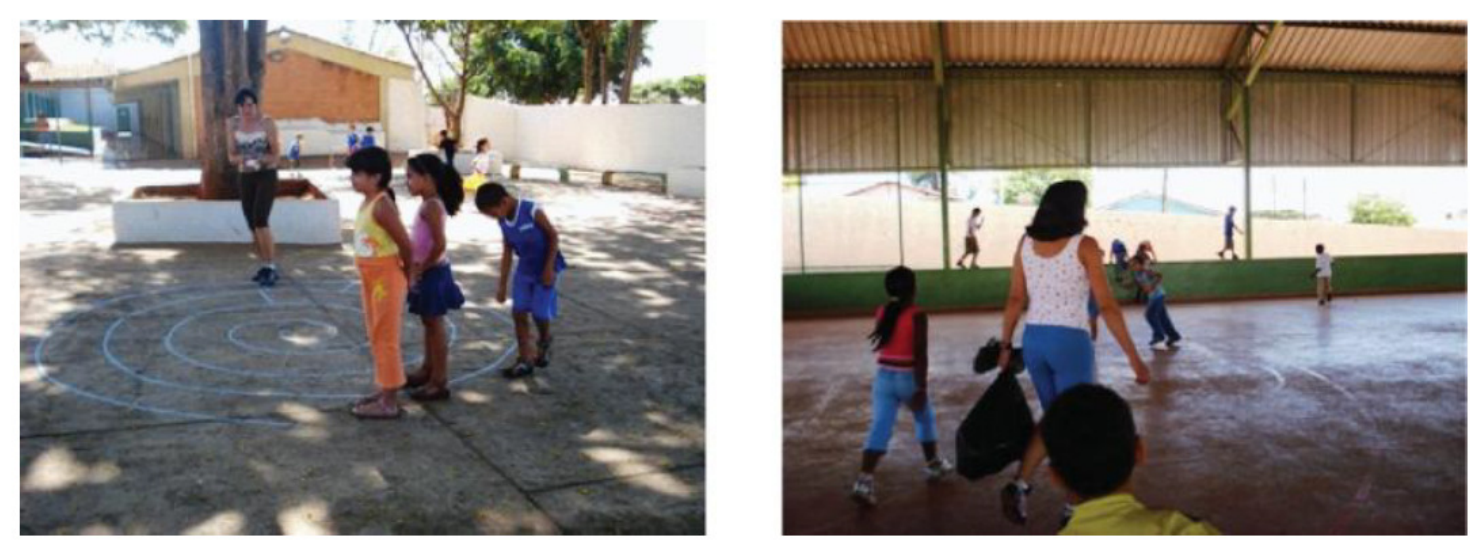

Figura 26. Brincadeiras dirigidas com as crianças de primeiro ano realizadas em aulas de Educação Física.

Fonte: Costa (2009), p. 174.

Os resultados encontrados por Marcondes (2012) e Costa (2009) são relatados também nos estudos de Jacomini, Rosa e Alencar (2012) e Correa (2010). A pesquisa desenvolvida por Jacomini et al. (2012) em Diadema envolveu observações do cotidiano escolar de uma turma de primeiro ano de uma escola municipal de Ensino Fundamental e outra turma de 
primeiro ano de uma escola de Educação Infantil. A partir das observações os autores perceberam que a escola de Ensino Fundamental contava com poucos espaços lúdicos e que o brincar acabava se limitando às aulas de educação física, por meio de brincadeiras dirigidas:

As observações na escola de Ensino Fundamental indicaram pouco espaço para as crianças brincarem. De acordo com as professoras, isso ocorria nas aulas de educação física, no entanto, eram brincadeiras dirigidas e não o brincar pelo brincar, que é o que as crianças gostam (JACOMINI, ROSA e ALENCAR, 2012, p. 236).

Este estudo traz ainda outras contribuições para a discussão do brincar no primeiro ano ao envolver observações de uma turma de primeiro ano atendida em uma escola de Educação Infantil, que não refletia a realidade observada na escola de Ensino Fundamental acompanhada na pesquisa. Os autores apontam que na escola de Educação Infantil foi observada maior frequência das brincadeiras e atividades lúdicas na rotina das crianças de primeiro ano. O relato de uma professora desta escola, obtido por meio de entrevista concedida às pesquisadoras, confirma a presença constante de atividades lúdicas na rotina do primeiro ano:

Todos os dias eles têm um espaço de 30 a 40 minutos que a gente desenvolve brincadeiras com eles, [...] duas vezes por semana eu trago no parque, uma vez por semana a gente vê um vídeo, uma vez por semana a gente faz brincadeira de corpo e movimento, que já são brincadeiras dirigidas e, uma vez por semana tem monta-monta ou a massinha, também em sala de aula (JACOMINI, ROSA e ALENCAR, p. 236).

Comparando-se os dados das observações nas duas escolas, os autores apontam que o atendimento às crianças de primeiro ano na escola de Educação Infantil se mostrou mais adequado às necessidades das crianças de seis anos, por esta oferecer infraestrutura para o brincar (parque, brinquedoteca) e uma rotina mais direcionada para as demandas das crianças de seis anos.

A pesquisa de Moro (2009) também relata ter observado poucos momentos destinados ao brincar no cotidiano escolar. Seu estudo apresenta resultados obtidos por meio de entrevistas com professoras de primeiro ano de três escolas de Curitiba (PR), visando conhecer e analisar a visão de professores sobre o ensino fundamental de nove anos. Segundo a pesquisadora, todas as escolas possuíam parque infantil, porém, o acesso das crianças do primeiro ano ao parque era limitado: "sobre o parque, todas as professoras entrevistadas referiram que seu uso no cotidiano educativo do $1^{\circ}$ ano estava estabelecido somente em um horário por semana, nas três escolas consideradas" (MORO, 2009, p. 218). Segundo as 
professoras, o parque era uma conquista recente da escola, que deveria ser mais aproveitado pelas crianças:

Nós temos o parque aqui, que é uma grande conquista, [...] eu estou há 13 anos nessa escola e no ano passado foi adquirido esse parque. Mas foi montado um horário para que todos os alunos da escola pudessem usar. Com isso, ... a turma do primeiro ano usa uma vez por semana... e ... eu acho muito pouco! (MORO, 2009, p. 218).

A professora aponta ainda outro problema da limitação do acesso das crianças ao parque:

Eu fiquei com o dia da sexta-feira, então... Parece uma coisa... Chega final de semana chove, aí as crianças ficam sem parque. Daí eles passam a semana toda me perguntando: "Professora, vai ter parque hoje? Quando que vai ter parque? É hoje o dia do parque?" (MORO, 2009, p. 218).

Segundo Moro (2009), esta limitação do parque a uma vez na semana foi justificada por uma das escolas como consequência desta atender um grande número de crianças. Um dado interessante é que, nesta escola, as demais crianças do ensino fundamental também usufruíam do parque uma vez por semana, permitindo que estas tivessem acesso a este espaço lúdico que é uma conquista recente nas escolas de ensino fundamental. As outras duas escolas investigadas não deram justificativas para o pouco uso do parque no planejamento semanal do primeiro ano.

Analisando-se as pesquisas, observou-se também que são comuns relatos de situações em que o momento destinado ao brincar acaba sendo ocupado com atividades em sala de aula destinadas à sistematização do ensino, como explicita Correa (2011a):

No cronograma de atividades semanais [...] observamos que estava prevista ao menos uma saída diária para o parque, mas, na prática, era muito comum que esse tempo fosse ocupado em sala, com aqueles exercícios [como cópia e pontilhado], uma vez que as crianças demoravam mais para completá-los (p. 113).

Assim, muitas vezes, apesar de haver um horário destinado ao parque, por exemplo, as crianças não poderiam desfrutar deste direito enquanto não terminassem as atividades propostas em sala de aula.

Também no estudo de Moro (2009), foi possível perceber a partir dos depoimentos das professoras que, apesar de haver uma preocupação entre elas em incluir o brincar e outras formas de expressão no cotidiano, estas não eram prioridades em seu planejamento: 
E às vezes eles mesmos vêm me cobrar: "Professora, você dá uma folha para desenhar!". Já fez alguns dias que passou e eu não percebi... [...] "Terminou a tarefinha, oh uma folha para você fazer um desenho livre". [...] "Ah professora eu estou cansada agora, minha mão está doendo", sabe? Daí eu tento me policiar, então eu vou fazer uma atividade mais lúdica (MORO, 2009, p. 222).

Para a pesquisadora, os depoimentos das professoras "dão a entender que as atividades são necessárias apenas porque as crianças gostam de realizá-las” (MORO, 2009, p. 220). Observa-se no relato acima que não há relação entre o desenho e a atividade exercida anteriormente, e que as atividades lúdicas são muitas vezes propostas nas "sobras" de tempo.

O estudo de Rocha (2009) aponta resultados semelhantes. Com o objetivo de analisar as condições oferecidas para a atividade lúdica nas escolas, a autora realizou observações participantes em oito turmas de primeiro ano, de cinco escolas municipais localizadas no interior de São Paulo. Segundo Rocha (2009), foi possível perceber que o brincar estava presente no cotidiano das oito turmas observadas. Em contrapartida, as observações também permitiram identificar que, na maior parte do período em que permaneceram nas escolas, as crianças estiveram ocupadas em atividades de leitura, escrita e matemática, sendo frequente o "deslocamento do brincar para as sobras de tempo" entre uma atividade e outra (ROCHA, 2009, p. 207).

Com isso, observamos que as pesquisas sobre o ensino fundamental de nove anos ressaltam que há uma preocupação em inserir o brincar no cotidiano escolar, especialmente das turmas de primeiro ano, mas que de forma geral este ainda é pouco valorizado, ocorrendo na maior parte das vezes dissociado do ensino e sendo deslocado para segundo plano. Como afirma Fontes (2009, p. 123), o que se observa é que "a ludicidade que perpassa toda a trajetória escolar da criança na educação infantil, desaparece ou se reduz apenas a alguns horários ou componentes curriculares em favor das atividades em torno da sistematização dos conhecimentos", sobretudo a leitura e escrita.

A análise dos resultados anunciados pelas pesquisas da revisão indicou, ainda, a convivência de diferentes usos para o brincar, surgindo no cotidiano escolar como:

- uma atividade de descanso entre uma atividade e outra (CORREA, 2010; CORREA, 2011; KLEIN, 2011; MOYA, 2009; MORO, 2009; ROCHA, 2009; ZINGARELLI, 2011); 
- um instrumento para sistematização do ensino (FONTES, 2009; KLEIN, 2011; MORO, 2009; RANIRO, 2009);

- um recurso disciplinador (ABREU, 2010; BARBOSA, 2009);

- um conteúdo a ser ensinado para as crianças (MAREGA, 2010).

Os estudos descritos a seguir indicam estes diferentes usos para o brincar no cotidiano escolar, em consonância com os demais estudos desta revisão que analisaram esta questão.

O estudo de Moya (2009) envolveu a realização de entrevistas com profissionais da educação de duas escolas da rede municipal de ensino de um município do Estado do Paraná, visando analisar o trabalho pedagógico realizado no primeiro ano do ensino fundamental, especialmente quanto aos conteúdos de ensino e à atividade lúdica. De acordo com o resultado apontado pelas entrevistas, a autora observou que o lúdico era utilizado no cotidiano escolar como descanso das atividades pedagógicas, ganhando espaço apenas quando as crianças estavam cansadas dos conteúdos de ensino. Questionadas sobre a importância do brincar, as professoras apontaram para seu uso como descanso:

Para descontrair as crianças, assim ela sente mais vontade de frequentar a escola. Elas gostam de brincar, não preciso chamar atenção para as brincadeiras, elas demonstram desempenho (MOYA, 2009, p. 152).

De forma semelhante, Correa (2011) observou que as brincadeiras eram, de modo geral, percebidas pelas docentes "como atividades livres que devem se desenvolver espontaneamente e em momentos tidos como de descanso entre uma lição/tarefa e outra" (p. 113).

O brincar é visto nas pesquisas também como recurso para o ensino de conteúdos, por meio de brincadeiras e jogos que visam ao ensino ou à sistematização de conteúdos. O estudo de Raniro (2009) aponta que o objetivo das professoras na utilização das brincadeiras e recursos lúdicos era direcionado para o trabalho da leitura e escrita com as crianças. As falas das professoras retratam os resultados apontados por Raniro (2009), em que PA e PC são professoras, e $\mathrm{P}$ é a pesquisadora:

PA - Eu trabalho com jogos, livros, atividades em folhas, caderno, recorte, colagem, música, poesia, conto, fábula, alfabeto móvel (...) Eu acho que funciona muito trabalhar com alfabeto móvel. (...) Formo duplas. Eu ponho, um em cada nível, por exemplo, um silábico com valor com um silábico sem valor, ou um silábico com valor com um silábico-alfabético. Então, um sempre sabendo mais do que o outro. Pra quê? Pra que isso surja a... Curiosidade e ter como discutir o que eles estão fazendo. (...) Então pra elas, 
o que? Isso aí é uma intervenção pra elas nunca ficarem acomodadas na mesma hipótese.

$\mathrm{P}$ - Então jogos você acha que é uma estratégia legal?

PC - Jogos, bingo de letras... Eles adoram e eu acho que dá um bom resultado também, eles pedem até hoje. Eu dei mais por conhecimento de letras mesmo (p. 122-123).

Assim, observa-se que o brincar é visto como oportunidade de que as crianças avancem na aprendizagem da leitura e escrita. Klein (2011) também observou em sua pesquisa o uso do brincar direcionado para o trabalho de alfabetização das crianças: "em sala de aula, momentos destinados à brincadeira contavam com jogos pedagógicos, como jogos de bingo e jogos de dominó envolvendo quantidades e sílabas, configurando a 'brincadeira didatizada"” (KLEIN, 2011, p. 189).

A pesquisa de Marega (2011), realizada em uma escola de ensino fundamental da rede municipal de Maringá, revela que na escola investigada o brincar foi tratado como um conteúdo a ser trabalhado com as crianças. A pesquisa retrata que o brincar apareceu na Proposta Curricular para o primeiro ano, contemplada no Projeto Político Pedagógico da escola, como um conteúdo do eixo "natureza e sociedade", ao lado de outros temas como "higiene", "alimentação", "meios de transporte", entre outros. A autora perguntou à coordenadora e à professora sobre como era realizado este trabalho do conteúdo "brincadeira", ao que elas responderam: "trabalhamos aqui as diversas brincadeiras infantis. Falamos sobre o estatuto da criança que assegura a elas o direito de brincar" (MAREGA, 2010, p. 93).

Nas pesquisas de Abreu (2010) e Barbosa (2009) foi possível observar o uso do brincar associado à disciplina, sendo utilizado pelos docentes como forma de recompensar ou não os comportamentos das crianças tidos como adequados.

Na pesquisa de Barbosa (2009), observou-se que a restrição do brincar era utilizada pelas professoras como método para disciplinar os alunos e obter sua atenção e para as atividades propostas em sala de aula. Assim, a restrição do momento de brincar surge como ameaça à indisciplina na fala das professoras:

Quem não ficar sentado quietinho fazendo as tarefas não vai sair para brincar no final da aula (Prof ${ }^{a}$ Margarida).

Continuem com esse comportamento, desobedientes, para ver quando que vocês vão ao parque. Nunca ouvi dizer que crianças teimosas saem para

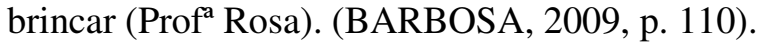


A pesquisa de Abreu (2010), realizada em uma escola municipal do interior de Pernambuco, por meio de entrevistas coletivas com crianças de seis anos, mostra que o acesso aos brinquedos também assumiu este caráter disciplinador. Segundo as crianças, só tem acesso aos brinquedos os alunos que "se comportam":

Pesquisadora: A professora dá os brinquedos?

Inês: A professora só dá os brinquedos se a pessoa ficar quieta (ABREU, 2010, p. 54).

Assim, como afirma Abreu (2010), o brinquedo assume a função de instrumento para a manutenção da disciplina. Para a pesquisadora, “o acesso aos brinquedos não deve [...] ser um prêmio aos alunos de conduta exemplar, mas um direito de cada criança, que the permite momentos de descanso e lazer" (p. 54). Além disso, a autora alerta também para a importância do uso do brincar aliado ao ensino: "Como objetos que despertam o interesse, eles podem ser utilizados como recurso para ajudá-las [as crianças] a aprender" (ABREU, 2010, p. 55).

Com isso, observa-se que o brincar está inserido no cotidiano escolar do primeiro ano com diversos usos e em variadas situações, surgindo como atividade direcionada ao ensino de conteúdos, como atividade de descanso, como instrumento regulador do agir das crianças, e até mesmo como um conteúdo a ser ensino, apontando para as crianças o seu direito de brincar, sem necessariamente garanti-lo. Neste contexto, pouco se observa o brincar como forma de expressão das crianças, e como forma destas explorarem e aprenderem sobre o mundo.

Aliado a isto, as pesquisas mostram ainda que os professores não participam das brincadeiras junto com os alunos. As pesquisas de Correa (2010), Correa (2011), Nogueira (2011) e Mascioli (2012) destacam este fato, apontando que durante as observações realizadas as professoras optavam na maior parte das vezes por apenas supervisionar a brincadeira: "a maioria das vezes em que brincaram em sala de aula, as crianças apenas fizeram jogos ou brincadeiras entre elas e sob a supervisão da professora, embora sem sua efetiva participação" (NOGUEIRA, 2011, p. 272). Mascioli (2012), em conversa com as crianças, percebeu que estas gostariam que houvesse maior participação e intervenções por parte da professora durante as brincadeiras vivenciadas. A fala das crianças citadas abaixo indica que, para elas, esta participação é importante, ao lembrar com prazer de uma situação em que isso ocorreu:

Lara: Outro dia a tia brincou com a gente no parque de gato mia. Foi muito legal. 
Augusto: Foi. Eu gostei quando ela deu duro ou mole.

Andréa: Eu também. E também quando ela brincou com a gente na casinha e tomou nosso cafezinho. Lembra Ana? (MASCIOLI, 2012, p. 196).

Diante destes resultados que ressaltam a pouca valorização do brincar por meio de seu tempo restrito e da não participação e intervenção dos professores nas brincadeiras, é possível questionar quais as concepções que embasam os diferentes usos do brincar no cotidiano escolar. Borba (2007) já apontava em seu artigo publicado no documento "Ensino fundamental de nove anos: orientações para a inclusão da criança de seis anos" (BRASIL, 2007), que "a brincadeira está entre as atividades frequentemente avaliadas por nós como tempo perdido" (p. 35).

Os resultados apresentados pelas pesquisas analisadas e aqui descritos demonstram que pouco mudou com relação a esta visão do brincar, sendo ainda visto na maior parte das vezes como dissociado do ensino. Como descreve Correa (2010), os docentes muitas vezes não sabem como proceder com as crianças de seis anos, e mesmo percebendo a necessidade que elas têm de brincar, contam com espaços e materiais restritos para sua inserção no cotidiano escolar. Além disso, com a falta de formação específica para o lúdico e a cobrança por resultados na alfabetização, os docentes não conseguem vislumbrar meios de garantir o direito à brincadeira sem prejuízos para a aprendizagem - assim, o brincar seria um impeditivo à aprendizagem, especialmente da escrita e da leitura (CORREA, 2010).

Como afirma Borba (2007), "essa visão é fruto da ideia de que a brincadeira é uma atividade oposta ao trabalho, sendo por isso menos importante, uma vez que não se vincula ao mundo produtivo, não gera resultados" (p. 35). Mesmo quando o uso do brincar surge associado ao ensino, surge como forma de sistematizar o ensino de conteúdos, como uma atividade dirigida, sem a mediação do docente, com vistas a memorização do conteúdo ensinado. Segundo Bonamigo (2010), neste contexto "apresenta-se uma incongruência [...] entre a espontaneidade, o jogo, e a organização do trabalho pedagógico" (p. 154). Conforme afirma Moro (2009), “devido a isso não ficam asseguradas as possibilidades para que o brincar [...] faça parte das práticas pedagógicas e educativas para as crianças nesse ano escolar" (p. 219).

Portanto, os resultados indicam que pouco mudou, com a implantação do ensino fundamental de nove anos, sobre a concepção do que é o brincar e sobre sua importância para as crianças. Contudo, observa-se que o brincar está mais presente no cotidiano escolar do ensino fundamental a partir de sua ampliação para nove anos. Isso permite inferir que esta 
maior presença do brincar no ensino fundamental ocorre em virtude das orientações, das cobranças, e das melhores condições - ainda que restritas e insuficientes - para inclusão do brincar, instigadas com a implantação do ensino fundamental de nove anos. Com isso, são as orientações presentes nos documentos oficiais do Ministério da Educação e as iniciativas das Secretarias Municipais de Educação com a implantação do ensino fundamental de nove anos que embasam a inserção do brincar no cotidiano escolar, e se refletem nas práticas docentes.

A pesquisa de Raniro (2009) é exemplo desta situação, em que a professora indica desconhecimento da importância do brincar, mas busca oferecer brinquedos às crianças para atender às orientações e exigências que recebe:

P - Eu já vi, por exemplo, você dando os brinquedos pra eles. (...) Se você desse aula no segundo ou terceiro ano você não utilizaria essa prática? PC - Não.

$\mathrm{P}$ - Você utiliza porque é um primeiro ano?

$\mathrm{PC}$ - Sim, porque quando começou o primeiro ano eles mandaram um monte de brinquedos, pro primeiro ano, porque primeiro ano tem que brincar (p. 120).

O depoimento desta professora revela que a inserção do brincar no ensino fundamental tem ocorrido para atender às orientações e exigências dos órgãos públicos, sem demonstrar uma real compreensão da importância do brincar no desenvolvimento das crianças e na garantia de seus direitos. O depoimento revela, ainda, que em virtude dos brinquedos terem sido enviados para o primeiro ano do ensino fundamental, a professora compreende que é apenas o primeiro ano que "tem que brincar".

Assim, vê-se claramente que apenas orientar e cobrar para a realização de um trabalho na perspectiva lúdica não garante que os professores poderão realizar um trabalho com qualidade nesta perspectiva. Como afirma Bonamigo (2010),

Apesar do discurso da garantia do direito à infância permear as propostas colocadas em prática, a organização do trabalho e as atividades propostas mostram a infância negada - tempos e espaços pré-determinados com participação mínima dos desejos das crianças (p. 154).

Assim, apesar do discurso dos documentos primarem pela garantia do direito das crianças ao brincar, a forma como este tem sido inserido no ensino indica que sua presença ainda é restrita e não se configura como forma de expressão das crianças, como "modo de ser e estar no mundo" (BORBA, 2007, p. 35). 
Para Vargas (2010) os docentes muitas vezes não possuem embasamento em sua formação para trabalhar com práticas que respeitem a infância e valorizem o lúdico. Com isso, "um trabalho na perspectiva lúdica é dificultado devido à defasagem na formação e na escolarização destas professoras, as quais foram frutos das práticas tradicionais e escassez de atividades lúdicas" (p 176-177). Para a autora, trabalhar numa perspectiva lúdica "requer muitos conhecimentos frente às necessidades infantis, à imaginação, à criatividade e à espontaneidade das crianças; muita paciência com as atividades que envolvem movimento, linguagem, expressões corporais e simbólicas" (VARGAS, 2010, p. 175-176) - requer, portanto, formação específica para este trabalho. Nesse sentido, vale ressaltar a importante colocação de Oliveira (2011):

Não basta, portanto, a inserção de brinquedos e brincadeiras para que o lúdico esteja garantido na escola, pois, nessa perspectiva, "[...] as ações podem continuar a ser transformadas em programas a serem cumpridos por um aluno que continua a ser fabricado" (MUNIZ 2005, 2006, apud OLIVEIRA 2011, p. 87).

Para Dornelles (2011), com a inclusão das crianças de seis anos no ensino fundamental o que se observa é a diminuição do tempo para brincar e se expressar, em comparação à vivencia destas mesmas crianças na Educação Infantil. Nesse sentido, a autora questiona:

Ter um tempo para brincar era garantido para as crianças de 0 a 6 anos, o que me leva a questionar: qual o efeito dessa pedagogização, dessa racionalidade que vem reduzindo o tempo para brincar e de ser criança de 6 anos? Que infância é essa que estamos produzindo? Isso é bom para quem? (p. 152).

Dessa forma, conclui-se sobre este aspecto que a política do ensino fundamental de nove anos, apesar de promover uma inclusão do brincar nesta etapa de ensino, representa para as crianças de seis anos uma diminuição do tempo do brincar e aumento das cobranças quanto à disciplina e à aprendizagem de conteúdos (como discutido no capítulo sobre o currículo no primeiro ano).

Assim, acredita-se que enquanto não houver mudanças nas concepções dos profissionais da educação sobre a importância do brincar de forma que este seja de fato valorizado e compreendido como essencial no desenvolvimento das crianças, as necessidades e direitos das crianças não serão atendidas e respeitadas. Para tal, faz-se necessário e urgente a formação docente para um trabalho que respeite os direitos da infância. 
Antes de finalizar esta discussão, é importante ressaltar aqui algumas pesquisas que, por meio de observações, conversas com as crianças ou análise de desenhos produzidos por elas, evidenciam a importância do brincar para as crianças de seis anos (ARELARO, JACOMINI e KLEIN, 2011; BARBOSA, 2009; CORREA, 2010; COSTA, 2009; JACOMINI, ROSA e ALENCAR, 2012; KLEIN, 2011; NOGUEIRA, 2011; RANIRO, 2009; SAMWAYS, 2012; SCHIMITZ, 2008; SILVA, 2010).

As pesquisas de Arelaro, Jacomini e Klein (2011), Barbosa (2009), Jacomini, Rosa e Alencar (2012) e Samways (2012) mostram que, a partir de conversas com as crianças, foi possível perceber que o brincar é a atividade que elas mais gostam na escola. Arelaro, Jacomini e Klein (2011) afirmam que as crianças entrevistadas mostraram-se ressentidas pela falta de brincadeiras e dos espaços (parques e brinquedotecas) característicos da Educação Infantil. Na pesquisa de Jacomini, Rosa e Alencar (2012), o brincar foi citado no depoimento das crianças como um elemento muito importante no cotidiano. Barbosa (2009) mostra depoimentos de alunos do primeiro ano de que brincadeiras, jogos, atividades no parque e na quadra são as preferidas das crianças:

As crianças, em sua maioria, ao serem questionadas sobre o que gostam mais na escola, responderam que é brincar. Como relatou um dos alunos:

Eu gosto de brincar no parque, jogar bola na quadra, brincar de casinha. (aluna Talita).

Outra criança disse ainda:

Eu gosto quando a professora leva no pátio para jogar boliche, brincar de corre cotia, eu ganho sempre, sabia. Há! Também gosto de pega pega. (Aluno Antonio) (BARBOSA, 2009, p. 109).

Samways (2012) reuniu as respostas dadas por 40 crianças de seis anos participantes da pesquisa sobre o que elas mais gostavam de fazer na escola, e percebeu que a maior parte delas citou o brincar, como se observa no esquema abaixo: 


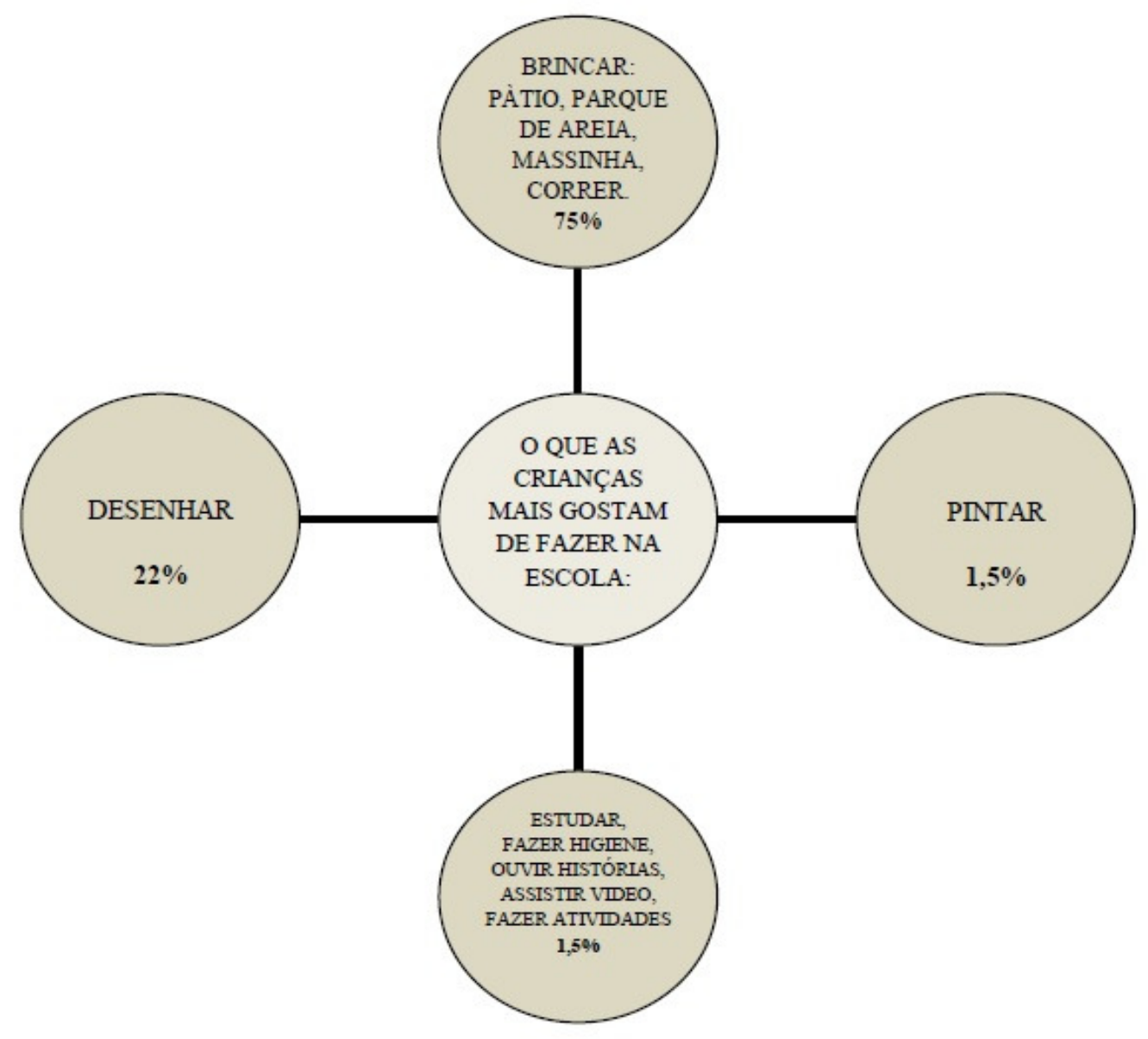

Figura 27. O que as crianças mais gostam de fazer na escola.

Fonte: Samways (2012), p. 106.

Com a Figura 27 pode-se observar que o brincar é citado pela maioria das crianças (75\%), em que foram registradas respostas como "brincar no pátio", "brincar na areia", "brincar no parque", "brincar de correr", "brincar de massinha", "brincar e desenhar" (SAMWAYS, 2012, p. 104). Outras respostas surgiram também, como "ouvir histórias" e “estudar e brincar" (SAMWAYS, 2012, p. 105).

As pesquisas de Schimitz (2008) e Raniro (2009) também ressaltam a importância do brincar para as crianças de seis anos, através de desenhos produzidos por elas. O estudo de Schimitz (2008), realizado em Santa Catarina por meio de observações de uma turma de Educação Infantil e uma de primeiro ano de Ensino fundamental, apresenta desenhos da escola feitos pelas crianças, em que é possível observar que as crianças da Educação Infantil representam a escola em desenhos mais coloridos do que as crianças de seis anos. Além disso, as crianças de seis anos representaram a sala de aula em sua organização em carteiras 
enfileiradas, com a professora à frente na lousa. Uma das crianças desenhou a si mesma em sala de aula, sentada na carteira, enquanto "sonhava" com o parque "lá fora":

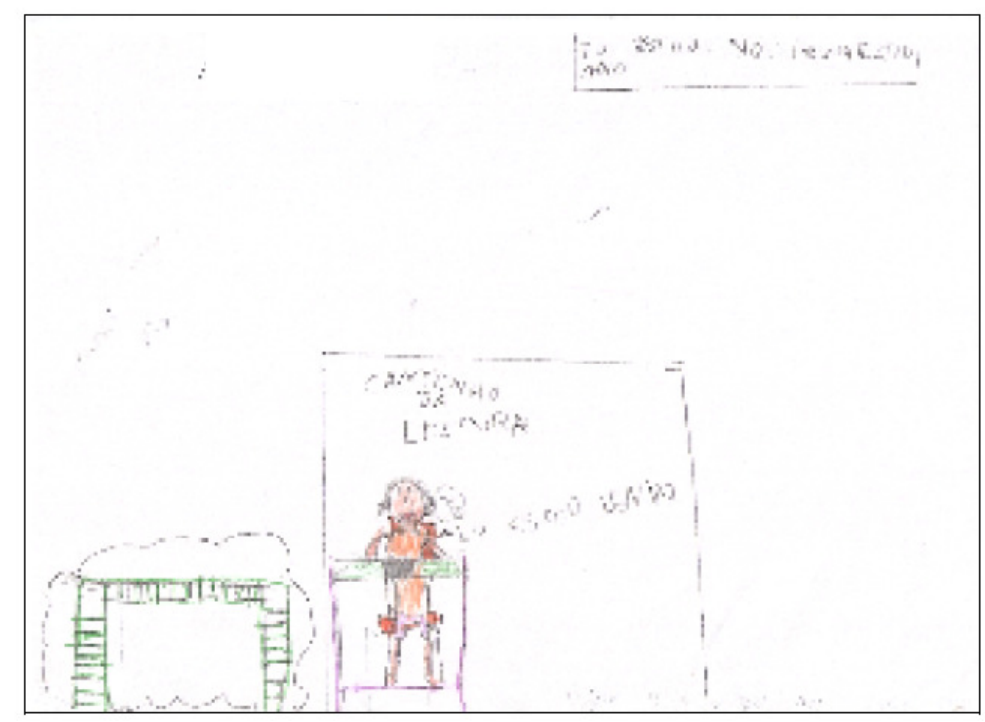

Figura 28. Desenho produzido por criança de seis anos em que ela se representa na sala de aula pensando no parque.

Fonte: Schmitz (2008), p. 72.

Este desenho é bastante representativo dos resultados sobre o brincar discutidos nesta revisão. Inserido em um cotidiano em que passa a maior parte realizando atividades em sala de aula, muitas vezes representadas por exercícios mecânicos e sem sentido para a criança, esta se vê desejosa por vivenciar outras experiências, outros espaços, em que participa de forma ativa, podendo se expressar e explorar o mundo à sua forma. $\mathrm{O}$ parque se constitui em um espaço onde a criança pode ter estas vivências, se configurando como um dos espaços que as crianças mais gostam nas escolas.

A pesquisa de Raniro (2009) mostra a importância da presença destes espaços na visão das crianças. Neste estudo, foi solicitado às crianças de primeiro ano que desenhassem a escola: uma escola de ensino fundamental da rede municipal de São Carlos (SP), que contava com parque e quadra para as crianças. Segundo a autora, das quinze crianças entrevistadas, seis representaram a quadra da escola nos desenhos e a maioria citou o parque e a quadra nas entrevistas. A Figura 29 mostra um dos desenhos produzidos pelas crianças, em que estão representados a quadra e o parque. 


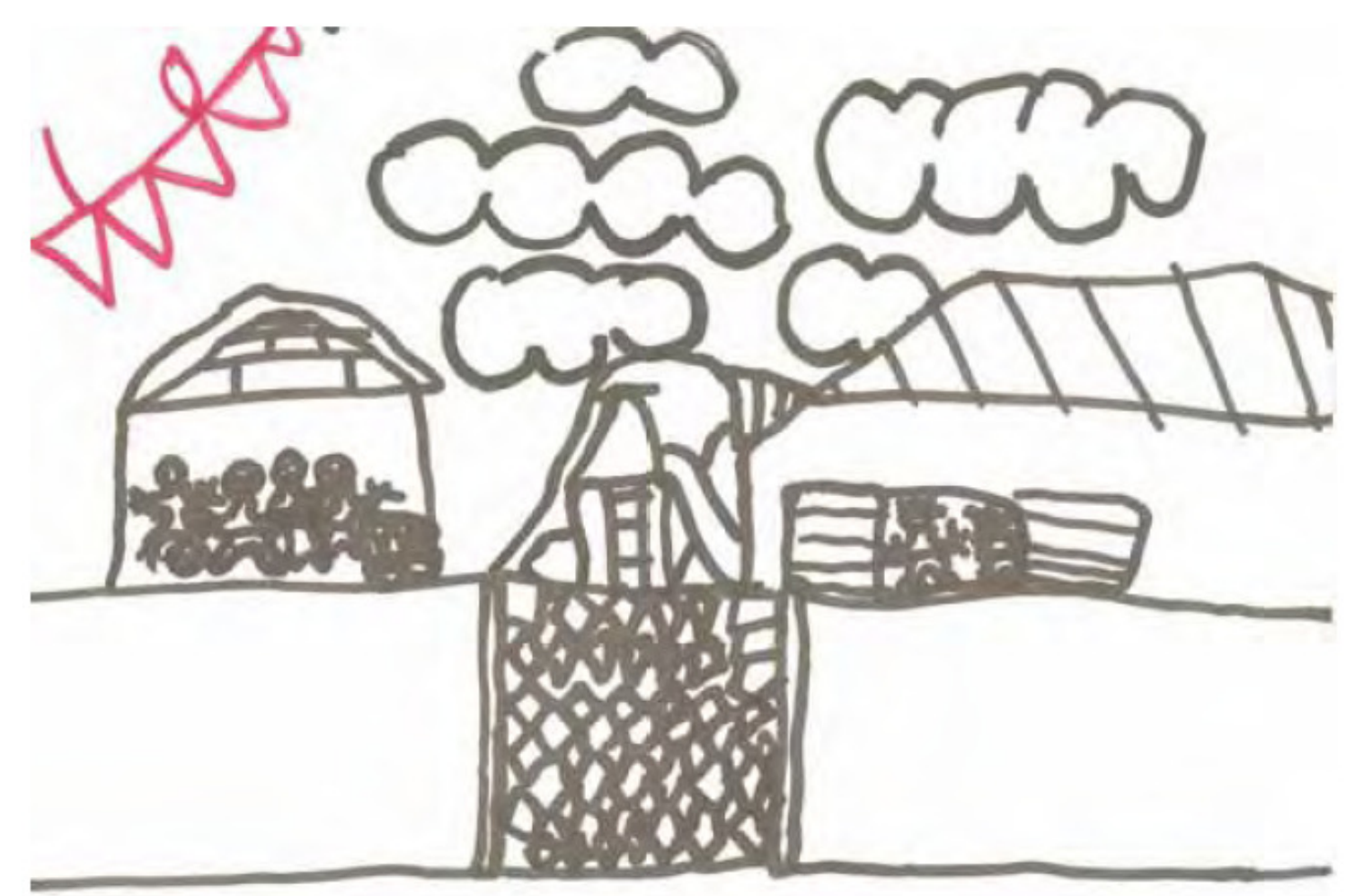

Figura 29. Desenho da escola produzido por criança de seis anos em que estão representados espaços como a quadra e o parque infantil.

Fonte: Raniro (2009), p. 87.

O desenho apresentado na Figura 29 representa, como afirma Raniro (2009), o espaço escolar da perspectiva de que a vê do lado de fora. É possível observar que o parque assume posição central no desenho, representado pelo escorregador. Ao lado esquerdo do parque, está representada a quadra, onde se encontram crianças brincando de bola (RANIRO, 2009). Observando que as crianças faziam questão de representar nos desenhos e citar nos depoimentos os espaços do parque e da quadra, Raniro (2009) afirma que "parece que estes são espaços, de fato, importantes para elas" (p. 86).

Como discutido anteriormente, é indispensável que as escolas contemplem diferentes espaços, de forma a proporcionar a garantia dos direitos das crianças à brincadeira em espaços diversificados, sendo o parque um importante espaço na garantia deste direito. Klein (2011), Silva (2010) e Samways (2012) também mostram em seus estudos que o parque e a quadra são espaços bastante valorizados pelas crianças. Segundo Klein (2011), o parque foi o ambiente mais citado pelas crianças para que uma escola seja considerada boa para elas. Samways (2012) relata uma situação em que, em um dia de chuva, as crianças não puderam ir ao parque, e "teve criança que pediu para ir ao parque mesmo com chuva" (p. 103). Silva 
(2010), em conversas com as crianças, observou que para elas os lugares mais interessantes da escola são o pátio, a quadra e o parque. Segundo a pesquisadora,

[...] elas falavam com entusiasmo desses lugares, revelando que neles podem se manifestar e ter mais autonomia em relação às decisões que devem tomar concernentes as suas vidas, diferentemente da sala de aula, que devem permanecer caladas e realizar as atividades propostas pela professora, como evidenciado na fala de Luiza (sete anos): "na sala a gente tem que ficar sentada o tempo todo, depois que a professora faz a chamada, a gente tem que fazer as atividades do quadro. Copia, copia, copia... É muito chato, a gente não pode nem brincar!" (SILVA, 2010, p. 196).

Assim, observa-se que espaços e vivências que possibilitem a criança se expressar e se manifestar são vistos como importantes pelas próprias crianças. Como revela a criança Luiza, citada por Silva (2010) no trecho acima, a sala de aula não representa para as crianças um destes espaços em que elas podem se manifestar.

Apesar da sala de aula não ser reconhecida pelas crianças como um espaço em que podem se manifestar, as pesquisas de Correa (2010), Costa (2009), Nogueira (2011), e Silva (2010) revelam que durante a permanência em sala de aula as crianças brincam, com ou sem uma organização intencional dos professores, e com ou sem a autorização destes.

Durante observações em uma escola de ensino fundamental em Goiânia (GO), Costa (2009) verificou que as crianças brincavam mesmo sem a autorização da professora, burlando em inúmeras situações a ordem vigente, para atender as suas necessidades de brincar. A Figura 30 mostra um dos alunos brincando durante a aula: 


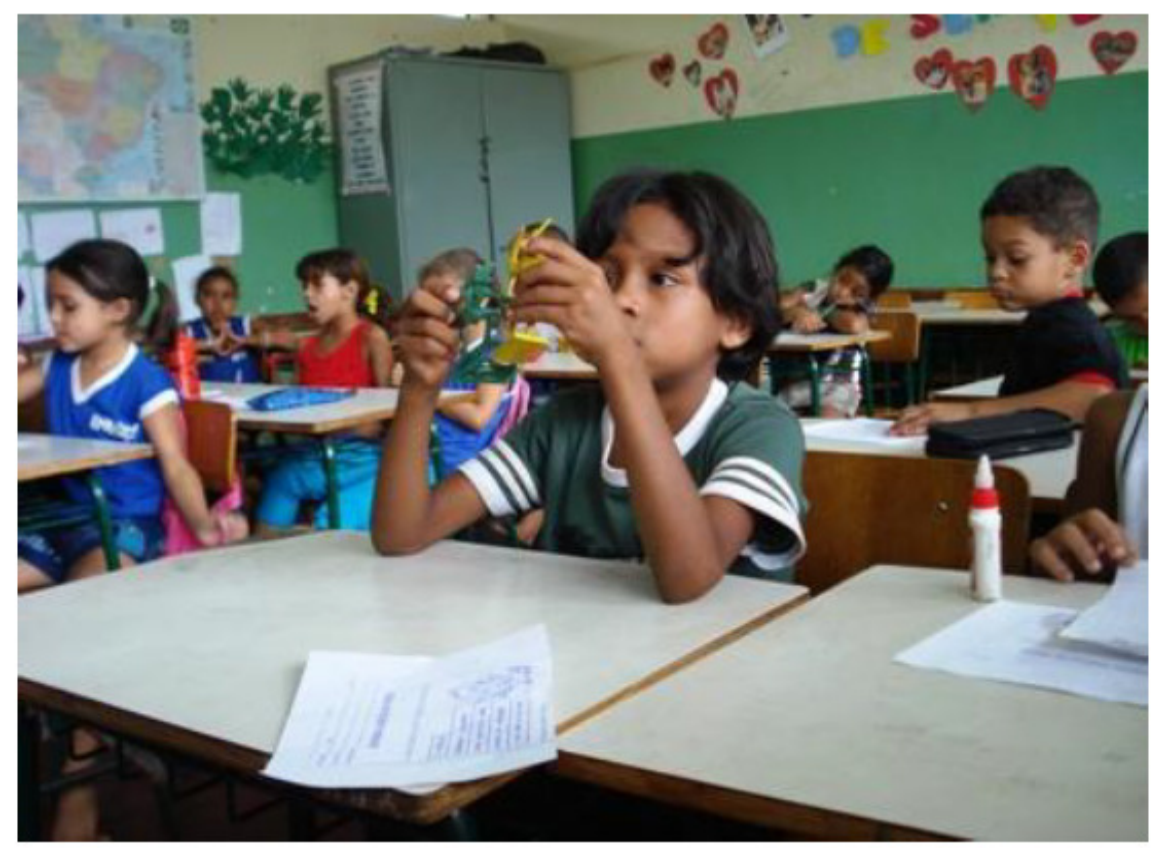

Figura 30. Criança brincando durante a aula.

Fonte: Costa (2009), p. 182.

Observa-se pela foto acima que a criança se mantém concentrada em sua brincadeira, enquanto a folha de atividade se encontra no canto da carteira, afastada de sua atenção. É possível observar ainda, ao fundo, crianças cujas expressões e posturas parecem indicar que estavam entediadas com a atividade proposta. Segundo Costa (2009), a professora repreendia os alunos que brincavam sem sua autorização, mas à menor desatenção da professora, o brinquedo voltava às mãos das crianças. Para a autora, "o confronto entre a vontade de brincar, que é característico da criança de seis anos de idade, e a obrigação com as tarefas escolares criava tensões e conflitos em diversos momentos" (COSTA, 2009, p. 183).

O estudo de Silva (2010) também observou crianças brincando em sala de aula sem a autorização da professora. Segundo a autora, o brincar é repreendido em sala de aula, e as crianças, em sua necessidade de brincar, brincam escondido embaixo da carteira, como mostra a Figura 31. 


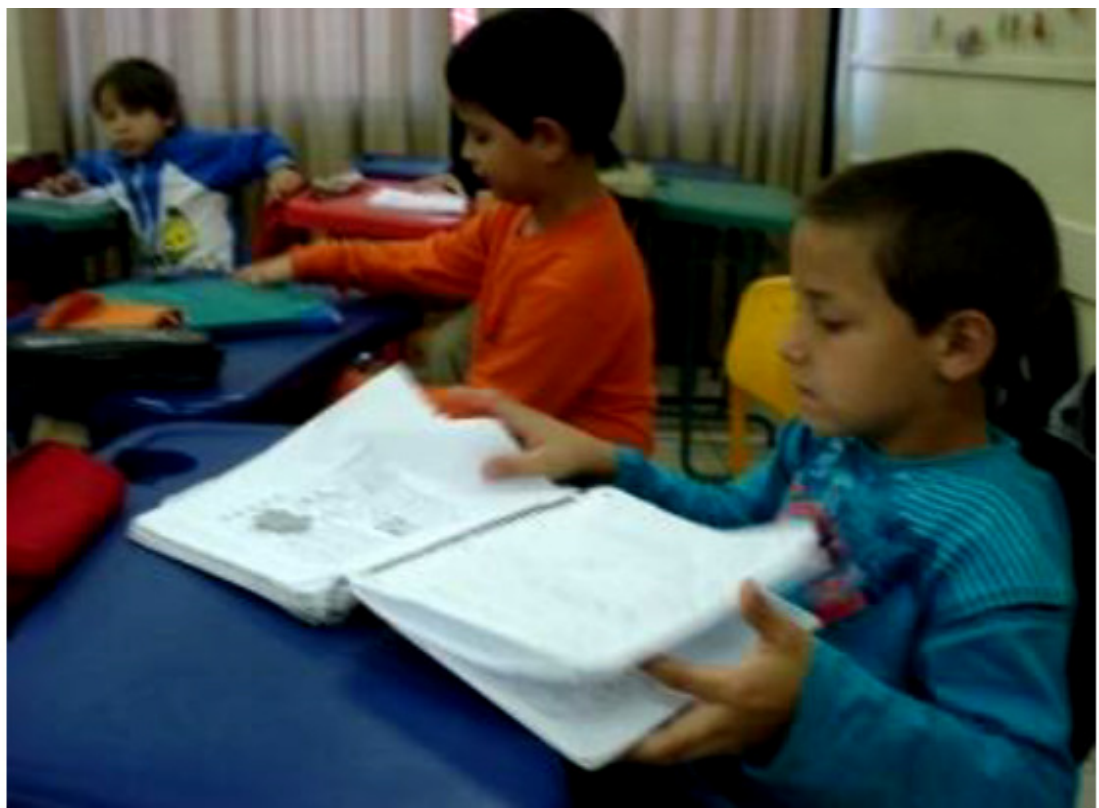

Figura 31. Criança brincando escondido embaixo da carteira.

Fonte: Silva (2010), p. 187.

$\mathrm{Na}$ figura acima é possível observar que o aluno de blusa alaranjada mantém sua atenção para a parte de baixo da carteira, onde estava brincando com um carrinho. Como afirma a Silva (2010), as crianças aproveitam os curtos momentos de "não vigilância da professora, para fazer aquilo que não lhe era permitido - brincar" (p. 189).

Nogueira (2011) também constatou que as crianças brincam em sala de aula mesmo sem autorização docente, e também apresenta registro fotográfico de momentos em que as crianças criam espaços para brincar em sala de aula, como é mostrado na Figura 32:
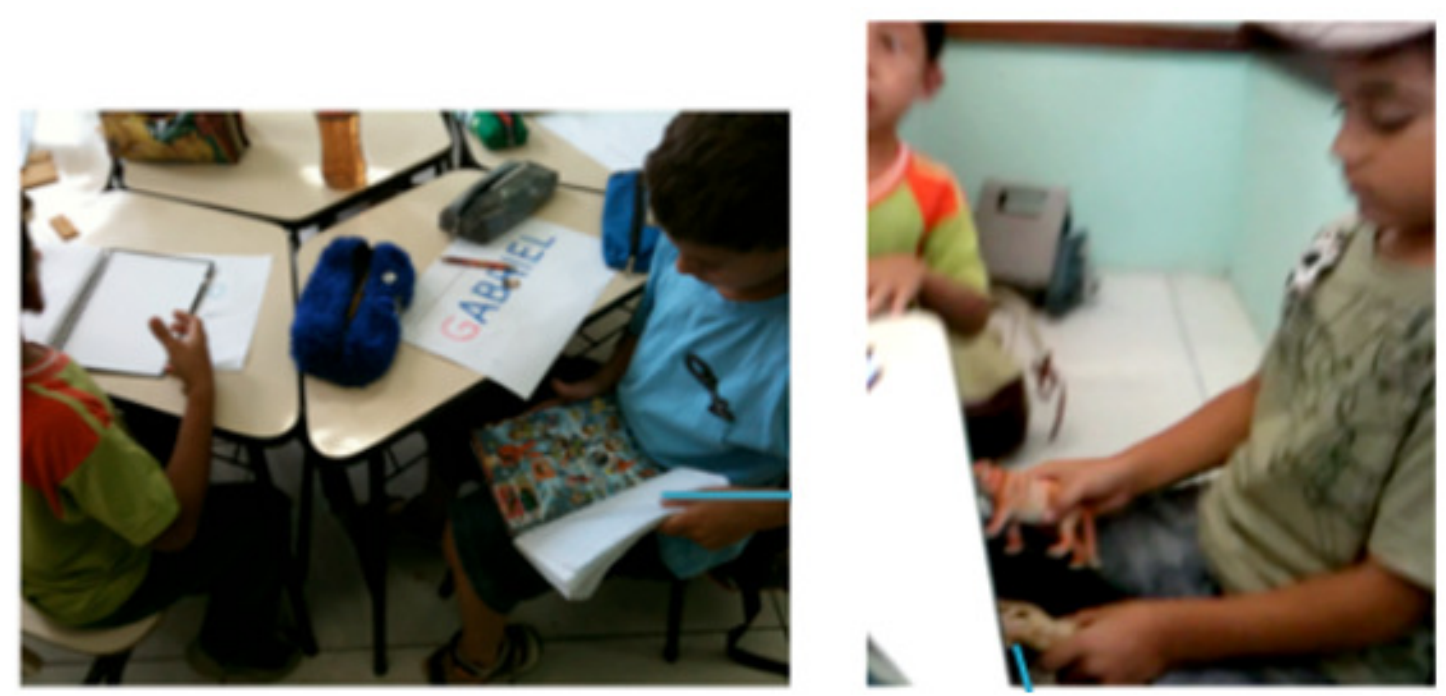

Figura 32. Crianças, em sala de aula, brincam escondido embaixo da carteira. Fonte: Nogueira (2011), p. 250. 
Na Figura 32 observam-se dois diferentes momentos capturados por Nogueira (2011) em que os alunos interagem com os brinquedos escondidos embaixo das carteiras: no primeiro, os alunos trocam figurinhas, e no segundo, um aluno brinca com miniaturas de animais. Para Nogueira (2011), a partir da interação com os brinquedos as crianças produzem uma situação à parte dos acontecimentos da aula. Assim, "situações como essas revelam que as crianças criam espaços para brincar, e quando esses não são oferecidos em algum momento específico da aula, elas ludibriam as regras de diversas formas" (NOGUEIRA, 2011, p. 249).

Portanto, depreende-se destas pesquisas que o brincar é de fato a forma das crianças vivenciarem e explorarem o mundo, sendo necessário que se faça presente no cotidiano escolar, em momentos e espaços destinados a estas vivências, assim como em sala de aula, permeando todo o processo ensino-aprendizagem. Como afirma Paro (2010), "a brincadeira e o lúdico não apenas são compatíveis com o ensino, mas também são necessários para que a aprendizagem se realize" (p. 67).

Ao analisar o que as pesquisas mostram sobre o brincar e o lúdico no primeiro ano do ensino fundamental de nove anos, foi possível observar uma maior consonância dos estudos quanto aos resultados. Como discutido anteriormente, as pesquisas indicam que, apesar de presente no cotidiano escolar, o brincar ainda é bastante restrito e pouco valorizado, prevalecendo sua compreensão como uma atividade sem fins educativos e para o desenvolvimento das crianças. Estes resultados parecem indicar que a política do ensino fundamental de nove anos, ao incluir as crianças de seis anos na estrutura do ensino fundamental, representa um risco à garantia dos direitos ao brincar e à infância.

Neste sentido, faz-se relevante ressaltar os dados das pesquisas que indicam a importância do brincar para as crianças de seis anos, na intenção de que todos os profissionais da educação "entendam que a construção do conhecimento para as crianças se dá a partir do brincar, o que torna a escola, também, um lugar alegre que possibilite que a infância seja vivida em sua plenitude por todos que estão nela" (BONAMIGO, p. 155). Portanto, são muitos os desafios que se configuram neste contexto para a plena garantia dos direitos das crianças à educação e ao brincar, e para tornar a escola este lugar alegre de vivência da infância em sua plenitude. 


\section{CONSIDERAÇÕES FINAIS}

Sem intenção de finalizar a discussão, serão realizadas aqui algumas reflexões possíveis diante do material aqui exposto. Assumindo as limitações existentes neste estudo, buscaremos, aqui, refletir sobre o que mostram os achados a partir das pesquisas sobre o ensino fundamental de nove anos e as contribuições e problemas gerados por esta política.

Com o objetivo de analisar o que as pesquisas mostram sobre a implantação do ensino fundamental de nove anos, o presente trabalho apresentou e analisou os principais aspectos apontados pelas pesquisas com relação à implantação do ensino fundamental de nove anos. Observou-se que o foco das pesquisas, de uma maneira geral, esteve centrado predominantemente no primeiro ano do ensino fundamental, ou seja, sobre o que aconteceu com as crianças de seis anos que ingressaram nesta etapa de ensino. Apesar de ser compreensível este enfoque devido à realocação dessas crianças para uma etapa de ensino com características e propósitos bastante diferentes da educação infantil, essa predominância também indica a carência de estudos que abordem como tem ocorrido a implantação do ensino fundamental de nove anos em uma perspectiva mais ampla.

Ao analisar os marcos políticos e legais no âmbito nacional e internacional que contextualizam a política do ensino fundamental de nove anos, foi possível observar que sua origem foi motivada essencialmente por interesses econômicos, com vistas a legitimar uma situação já praticada em vários entes federados, em que as crianças de seis anos eram matriculadas no ensino fundamental para que as redes de ensino pudessem usufruir os recursos financeiros do Fundef. Diante dos resultados apontados pelas pesquisas, verifica-se que as medidas do Ministério da Educação se mostraram insuficientes para o planejamento e orientação dos sistemas de ensino na implementação dessa política. As pesquisas ressaltam a falta de planejamento, de garantia das condições necessárias para a realização das mudanças, e de envolvimento e formação dos docentes como características marcantes neste processo de implantação do ensino fundamental de nove anos.

Os professores tiveram pouca participação na discussão sobre a ampliação do ensino fundamental, sendo na maior parte das vezes pegos de surpresa no momento da implantação dessa medida. Os cursos e espaços de formação propiciados não foram suficientes para orientar e sanar suas dúvidas, tampouco contemplaram a totalidade dos professores. As 
pesquisas evidenciaram que as condições do espaço físico das escolas não foram adequadas à inclusão das crianças de seis anos, e diversos problemas têm sido relatados nesse processo, como a falta de espaço e de financiamento para realizar as mudanças necessárias, em especial quanto à construção do parque infantil. Correa (2011) sintetiza de forma clara essa situação encontrada nos estudos analisados:

de modo geral, nossas políticas públicas têm priorizado os investimentos no ensino fundamental, sem aumentar de modo significativo o seu montante, ao mesmo tempo em que, na implantação de novas medidas, desconsideram a realidade da escola e não a preparam para as mudanças (p. 105).

Diante desses dados, o que se observa é que, como em muitas outras políticas públicas, primeiramente implanta-se a medida, para depois haver uma mobilização dos órgãos públicos para viabilizar sua implementação (MORO, 2009).

No rol das pesquisas analisadas, observou-se a predominância pela discussão do currículo, em particular da alfabetização e do letramento no ensino fundamental de nove anos. Aponta-se para a carência de estudos que abordam o ensino e a aprendizagem das demais áreas do conhecimento no primeiro ano do ensino fundamental.

Sobre o currículo, as pesquisas abordaram diferentes aspectos da questão, contribuindo para o enriquecimento do debate nesta temática. Elas mostraram a ausência de alterações significativas no currículo e a ênfase na alfabetização em detrimento do ensino das demais áreas do conhecimento. A manutenção de práticas pedagógicas tradicionais indica que as concepções dos professores não foram alteradas com a implantação do ensino fundamental de nove anos. Alguns estudos também revelaram que é recorrente nas escolas as exigências por disciplina e a vigilância por parte dos educadores em relação às crianças.

A análise apontou, ainda, que as formas avaliativas que têm sido adotadas no primeiro ano do ensino fundamental mantém um caráter classificatório. Isso aparece, principalmente, no que se refere às avaliações externas realizadas pelas secretarias de educação e nos testes nacionais, como a ANA e a Provinha Brasil, evidenciando as contradições entre a orientação dos documentos do Ministério da Educação e as avaliações que são realizadas pelos sistemas de ensino e pelo próprio MEC. Ainda se faz necessário o desenvolvimento de mais pesquisas acerca desta temática, que foi muito pouco abordada nas pesquisas, a fim de investigar as implicações das formas avaliativas empregadas no ensino fundamental na perspectiva de contribuir para a elaboração de alternativas que rompam com a lógica de associação do aluno ao seu desempenho nas avaliações. 
Frente ao desafio da incorporação das crianças de seis anos no ensino fundamental, observa-se que a atenção essencialmente voltou-se para a preparação da criança para as práticas enraizadas do ensino fundamental, e não para uma readequação e reestruturação dos currículos, das práticas e dos tempos e espaços escolares. Nesse sentido, percebe-se que

a proposta que se pretendia instituinte, manteve a instituição de determinadas concepções e práticas que gostaria de modificar, além de que, com a mudança de nomenclatura, muda-se a linguagem, mas não se mudam as práticas, não se produz novas significações (SILVA, 2012, p. 7).

Com relação ao brincar foi possível observar que não foram modificadas as concepções sobre sua importância para o aprendizado e desenvolvimento infantil. As pesquisas mostraram que, apesar de presente no cotidiano escolar, o brincar era pouco valorizado e aparecia restrito às sobras de tempo ou às aulas de Educação Física, prevalecendo sua compreensão como uma atividade sem fins educativos e que pouco contribui para o desenvolvimento das crianças. A partir da análise dos resultados das pesquisas foi possível observar a convivência de diferentes usos para o brincar, surgindo no cotidiano escolar como atividade de descanso, como instrumento para sistematização do ensino, como recurso disciplinador, ou mesmo como um conteúdo a ser ensinado para as crianças.

Os estudos mostraram, também, que o que as crianças mais gostam de fazer na escola é brincar, sendo o parque infantil e a quadra seus espaços prediletos. Algumas pesquisas apontaram que as crianças brincam, com ou sem o consentimento dos professores, criando espaços para satisfazer sua necessidade de brincar quando esses não the são oferecidos. Porém, muitas vezes o fazem escondido, com receio de serem repreendidos por brincar em sala de aula.

Com isso, as pesquisas indicam que a política do ensino fundamental de nove anos, apesar de promover uma inclusão do brincar nesta etapa de ensino, representa para as crianças de seis anos uma diminuição do tempo do brincar e um aumento das cobranças quanto à disciplina e à aprendizagem de conteúdos. Como afirma Moro (2009), "as crianças são as mesmas, mas o lugar que ocupam é que dita o que é permitido e esperado delas: brincar ou ser alfabetizadas, em um processo de dupla exclusão" (p. 215).

Para Arelaro, Jacomini e Klein (2011), a ênfase na alfabetização e a pouca valorização do lúdico podem ser compreendidas como 
um alerta acerca da tendência de nossa sociedade e, em certo sentido, das políticas educacionais exigirem de crianças, cuja principal demanda é o brincar, um esforço de adequação à disciplina dos tradicionais métodos da escola de ensino fundamental (ARELARO, JACOMINI e KLEIN, 2011, p. 48).

Portanto, a partir dos resultados encontrados na pesquisa avalia-se que a política do ensino fundamental de nove anos não representa uma efetiva ampliação de direitos, e da forma como vem ocorrendo até o momento, não se configura como uma medida que tenha beneficiado as crianças de seis anos de idade. Compreendendo o contexto em que surgiu a proposta, vê-se que se trata de uma política educacional motivada inicialmente pela demanda dos recursos do Fundef, que envolveu pouco planejamento e ausência de medidas para que houvesse melhorias na qualidade da educação e uma concreta ampliação de direitos.

Assim, observa-se que é urgente a necessidade de repensar as práticas no ensino fundamental, repensar os currículos, repensar todo o modelo vigente nesta etapa de ensino, embasando-se na perspectiva de um ensino mais significativo para as crianças e que seja garantido o seu direito de brincar. Contudo, é importante ressaltar que essas questões que estão colocadas para a escola não dizem respeito exclusivamente a ela. A escola, inserida nesse contexto de contradições desvelado pelas pesquisas, não pode ser pensada como algo à parte:

É tarefa da sociedade civil discuti-la, repensá-la e isso implica tomadas de consciência, processos de formação, políticas públicas sociais/educacionais que contribuam para garantir que crianças tenham seus direitos assegurados, vivam com dignidade e usufruam o patrimônio cultural construído ao longo do processo da humanidade. (AGUIAR, 2012, p. 5)

Em que pesem os limites da presente pesquisa, buscou-se contribuir para essa discussão apresentando as experiências e situações bem sucedidas relatadas por algumas pesquisas, que podem servir de referência, ou como um ponto de partida para novos caminhos a serem traçados na busca por uma educação de qualidade. Ademais, é importante ressaltar que ainda são poucas as pesquisas que relatam experiências positivas na implantação do ensino fundamental de nove anos, sendo necessárias novas investigações em contextos em que a implantação do ensino fundamental de nove anos envolva experiências bem sucedidas, ainda que parcialmente, para contribuir neste debate.

Em tempo, ressalta-se que as pesquisas analisadas pelo presente estudo se configuram como um universo a ser explorado, abrangendo diferentes enfoques, diferentes temáticas, 
diferentes concepções teóricas, diferentes participantes, contextos investigados com particularidades diferentes, e diferentes olhares dos pesquisadores na interpretação dos dados coletados. Dentro deste universo que se constituem as pesquisas há muitos dados interessantes e relevantes de serem analisados. Dado o objetivo desta pesquisa, foram focalizados os dados referentes à implantação do ensino fundamental de nove anos, não se aprofundando em importantes discussões adjacentes ao tema, como a infância no ensino fundamental e a transição da educação infantil para o ensino fundamental, agora com nove anos de duração. Assim, seria interessante que novas propostas de revisão se dedicassem a entretecer os resultados das pesquisas sobre estas outras temáticas. Além disso, atenta-se para a carência de pesquisas que buscam ouvir as crianças. Foram trazidas à discussão algumas pesquisas que se dedicaram a essa escuta, e considera-se que os dados por elas apontados são riquíssimos para a discussão do ensino fundamental de nove anos.

Por fim, diante do debate tecido até o momento, finaliza-se o presente trabalho incitando à reflexão a partir de uma tira de quadrinhos da série de Calvin e Haroldo, de autoria de Bill Watterson. Do ponto de vista de uma criança, acredita-se, esta tirinha expressa, de modo simples, conciso e interessante, a problemática das práticas pedagógicas tradicionais e do ensino descontextualizado, e alerta para a importância das brincadeiras e atividades lúdicas no desenvolvimento das crianças.
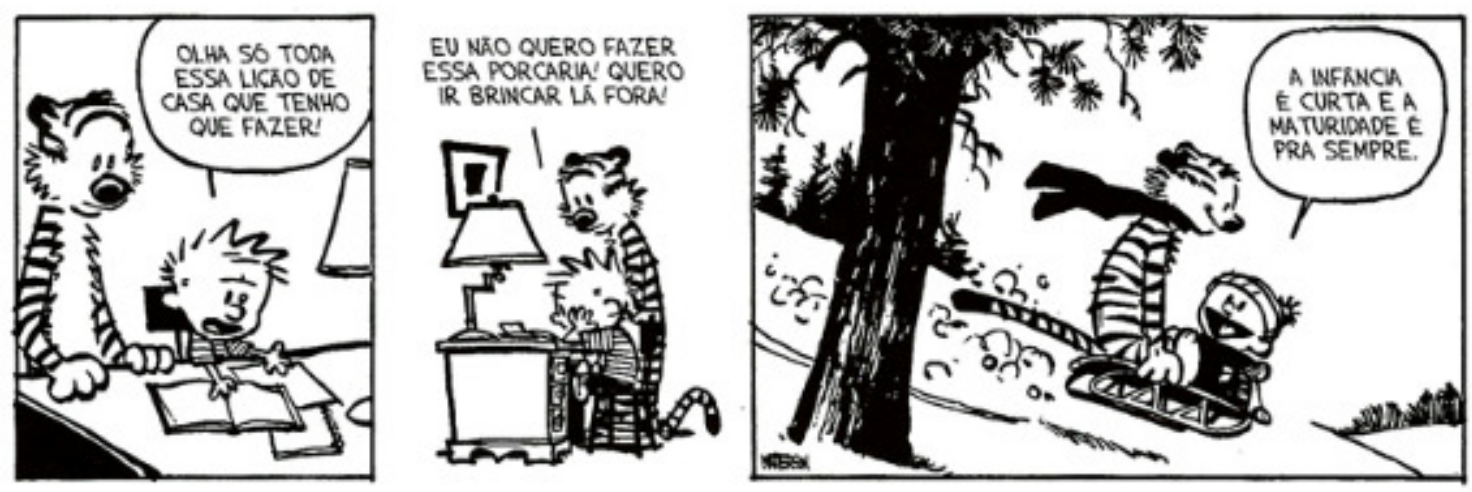

Fonte:www.facebook.com/DepositoDeTirinhas/photos/ 


\section{REFERÊNCIAS BIBLIOGRÁFICAS}

ABBIATI, A. S.; OLIVEIRA, C. Uma análise das manifestações do Conselho Nacional de Educação sobre a escola de nove anos. Revista de Educação PUC-Campinas, Campinas, v. 18, n. 1, p. 97-106, jan./abr., 2013.

ABDIAN, G. Z.; CIARDELLA, T. M. Ampliação do Ensino Fundamental para nove anos: entre as normatizações da política educacional, o movimento teórico e as representações sociais dos profissionais da escola pública. Práxis Educativa, Ponta Grossa, v.6, n.2, p. 177191, jul.-dez. 2011.

ABRAMOWICZ, A. Educação infantil e a escola fundamental de 9 anos. Olhar de Professor, Ponta Grossa, 9, mar. 2009. Disponível em: <http://www.revistas2.uepg.br/index.php/olhardeprofessor/article/view/1467/1112>.

ABREU, L. P. O ingresso no $1^{\circ}$ ano do ensino fundamental de nove anos: sentimentos revelados por crianças de uma escola pública. Dissertação (Mestrado em Educação). Pontifícia Universidade Católica de São Paulo - PUC-SP, São Paulo, 2010.

ABREU, M. M. O. Ensino fundamental de nove anos no município de Uberlândia: implicações no processo de alfabetização e letramento. Dissertação (Mestrado em Educação). Universidade Federal de Uberlândia, Uberlândia, 2009.

AGUIAR, M. A. L. A criança de seis anos e o ensino fundamental. In: Reunião Anual da ANPED, 35 ${ }^{a}$. 2012. Disponível em: http://www.anped.org.br. Acesso em 15 de outubro de 2011.

ALMEIDA, A. C. Ampliação da escolaridade obrigatória: alfabetização e letramento com crianças de seis anos no ensino fundamental. In: Reunião Anual da ANPED, 35 a 2012. Disponível em: http://www.anped.org.br. Acesso em 15 de outubro de 2011.

ALMEIDA, J. G. Ensino Fundamental de nove anos: ampliação da permanência e qualidade de ensino. EccoS - Revista Científica, São Paulo, n. 25, p. 159-179, jan./jun. 2011. Disponível em: <http://www.redalyc.org/articulo.oa?id=71521708010>.

ALVES, M. F.; ALVES, E. F. Gestão democrática na educação básica: políticas e formas de participação. Retratos da Escola, Brasília, v. 4, n. 7, p. 259-270, jul./dez. 2010. Disponível em: <http//www.esforce.org.br>.

AMARAL, A. C. T. O que é ser criança e viver a infância na escola: uma análise da transição da educação infantil para o ensino fundamental numa escola municipal de Curitiba. Dissertação (Mestrado em Educação). Universidade Federal do Paraná, Curitiba, 2008.

ANTUNES, J. Ensino fundamental de nove anos: em busca da legitimação no cotidiano escolar. Dissertação (Mestrado em Educação). Universidade Federal de Santa Maria, Santa Maria, 2010. 
ARAÚJO, R. C. B. F. Construindo sentidos para a inclusão das crianças de seis anos de idade no ensino fundamental de nove anos: um diálogo com professores. Dissertação (Mestrado em Educação). Universidade Federal de Juiz de Fora, Juiz de Fora, 2008.

ARELARO, L. R. G. O ensino fundamental no Brasil: avanços, perplexidades e tendências. Educação e Sociedade, Campinas, v. 26, n. 92, p. 1039-1066, 2005.

ARELARO, L. R. G.; JACOMINI, M. A.; KLEIN, S. B. O ensino fundamental de nove anos e o direito à educação. Educação e Pesquisa. São Paulo, v.37, n.1, pp. 35-51, jan./abr, 2011.

AZEVEDO, J. M. L. A educação como política pública. $3^{\text {a }}$ ed. Campinas: Autores associados. 2004.

BARBOSA, M. S. P. A implementação do $1^{\circ}$ ano no ensino fundamental de nove anos: estudo de uma experiência. Dissertação (Mestrado em Educação). Universidade Católica Dom Bosco, Campo Grande, 2009.

BERTINI, L. F.; CARAM, A.; CERMINARO, R. H. S.; REALI, A. M. M. R.; TANCREDI, R. M. S. P. Ampliação do ensino fundamental para nove anos: entre a teoria incompleta e a prática intempestiva. Educação em Revista, Marília, v.9, n.2, p.65-78, jul.-dez. 2008.

BEZERRA, D. R. S. Mudanças e continuidades da cultura da escola no contexto de implantação do Ensino Fundamental de Nove Anos. 2011. 162 p. Dissertação (Mestrado em Psicologia). Faculdade de Filosofia, Ciências e Letras de Ribeirão Preto, Universidade de São Paulo, Ribeirão Preto, 2011.

BOENO, R. M. Mudanças na forma de organização do ensino fundamental: um estudo no município de Dois Vizinhos - PR. Dissertação (Mestrado em Educação). Pontifícia Universidade Católica do Paraná - PUC-PR, Curitiba, 2011.

BONAMIGO, C.C. A inclusão da criança de seis anos no ensino fundamental: narrativas de práticas curriculares não instituídas. 2010. Dissertação (Mestrado em Educação) Universidade Estadual de Campinas, Campinas, 2010.

BORBA, A. M. O brincar como um modo de ser e estar no mundo. In: BRASIL. Ensino fundamental de nove anos: orientações para a inclusão da criança de seis anos de idade. $2^{\mathrm{a}}$ Ed. Brasília: Ministério da Educação, Secretaria de Educação Básica, 2007c.

BRANDÃO, M. O. M. Ensino fundamental de nove anos e possíveis implicações no processo de alfabetização: um estudo de caso. Dissertação (Mestrado em Educação). Pontifícia Universidade Católica do Rio Grande do Sul, Porto Alegre, 2012.

BRASIL. Constituição de 1934. Constituição da República dos Estados Unidos do Brasil. Rio de Janeiro: Assembleia Nacional Constituinte, 1934. Disponível em: $<$ http://www.planalto.gov.br>.

Constituição de 1937. Constituição dos Estados Unidos do Brasil. Rio de Janeiro: Presidência da República, 1937. Disponível em: <http://www.planalto.gov.br>. 
Constituição de 1946. Constituição dos Estados Unidos do Brasil. Rio de Janeiro: Assembleia Constituinte, 1946. Disponível em: <http://www.planalto.gov.br>.

Constituição de 1967. Constituição da República Federativa do Brasil. Brasília: Congresso Nacional, 1967. Disponível em: <http://www.planalto.gov.br>.

Lei $\mathbf{n}^{\circ} \mathbf{5 . 6 9 2}$, de 11 de agosto de 1971. Fixa as diretrizes e bases para o ensino de $1^{\mathbf{o}}$ e $2^{\circ}$ graus e dá outras providências. Brasília, 1971. Disponível em: $<$ http://www.planalto.gov.br>.

Constituição de 1988. Constituição da República Federativa do Brasil. Brasília: Senado Federal, 1988. Disponível em: < http://www.planalto.gov.br>.

Lei no . 8.069, de 13 de julho de 1990. Dispõe sobre o Estatuto da Criança e do Adolescente e dá outras providências. Brasília, 1990. Disponível em: <http://planalto.gov.br>.

Emenda Constitucional $\mathbf{n}^{\mathbf{0}}$ 14, de 12 de setembro de 1996. Modifica os arts. 34, 208, 211 e 212 da Constituição Federal e dá nova redação ao art. 60 do Ato das Disposições constitucionais Transitórias. Brasília, 1996a. Disponível em: <http://www.planalto.gov.br>.

Lei $\mathbf{n}^{\mathbf{0}}$. 9.394, de 20 de dezembro de 1996. Estabelece as diretrizes e bases da educação nacional. Brasília, 1996b. Disponível em: $<$ http://www4.planalto.gov.br/legislacao $>$.

Lei no. 9.424, de 24 de dezembro de 1996. Dispõe sobre o Fundo de Manutenção e Desenvolvimento do Ensino Fundamental e de Valorização do Magistério, na forma prevista no art. $60, \S 7^{\circ}$, do Ato das Disposições Constitucionais transitórias, e dá outras providências. Brasília, 1996c. Disponível em: <http://www4.planalto.gov.br/legislacao>.

Parecer CNE/CEB no 20/98, aprovado em 02 de dezembro de 1998. Consulta relativa ao ensino fundamental de nove anos. Brasília, Ministério da Educação/Secretaria de Educação Básica,1998. Disponível em: <portal.mec.gov.br>.

. Lei no . 10.172, de 9 de janeiro de 2001. Plano Nacional de Educação (PNE). Brasília, 2001. Disponível em: <http://portal.mec.gov.br/arquivos/pdf/pne.pdf>.

O ensino fundamental de nove anos: orientações gerais. Brasília: Ministério da Educação/Secretaria de Educação Básica, 2004a. Disponível em: <portal.mec.gov.br>.

Ampliação do ensino fundamental para nove anos: relatório do Programa. Brasília: Ministério da Educação/Secretaria de Educação Básica, 2004b. Disponível em: $<$ portal.mec.gov.br>.

Parecer CNE/CEB n ${ }^{\circ}$. 24/2004, aprovado em 15 de setembro de 2004. Estudos visando ao estabelecimento de normas nacionais para a ampliação do ensino fundamental para nove anos de duração. Brasília: CNE/CEB, 2004c. Disponível em: <portal.mec.gov.br>.

Câmara dos Deputados. Projeto de Lei $\mathbf{n}^{\mathbf{0}}$ 3.675, de 2004. Altera a redação dos art. $\overline{6^{\circ}}$, art. 29 , art. 30, inciso II, art. 32, caput, e art. 87, $\S 2^{\circ}$ e $\S 3^{\circ}$, inciso I, da Lei $n^{\circ} 9.394$, de 20 de dezembro de 1996, dispondo sobre a duração mínima de nove anos para o ensino 
fundamental, com matrícula obrigatória a partir dos seis anos de idade. Brasília, 2004d. Disponível em:

<http://www.mpba.mp.br/atuacao/infancia/leis/educacao/projeto_lei_3675_2004.pdf>.

Lei $\mathbf{n}^{\circ} . \mathbf{1 1 . 1 1 4}$, de 9 de maio de 2005. Altera os arts. $6^{\circ}, 30,32$ e 87 da Lei $n^{\circ} .9 .394$, de 20 de dezembro de 1996, com o objetivo de tornar obrigatório o início do ensino fundamental aos seis anos de idade. Brasília, 2005a. Disponível em:

$<$ http://www4.planalto.gov.br/legislacao $>$.

Parecer CNE/CEB n ${ }^{\circ}$. 06/2005, aprovado em 08 de junho de 2005. Reexame do Parecer CNE/CEB 24/2004, que visa o estabelecimento de normas nacionais para a ampliação do Ensino Fundamental para nove anos de duração. Brasília: CNE/CEB, 2005b. Disponível em: <portal.mec.gov.br>.

Resolução CNE/CEB no ${ }^{0}$ 3, de 3 de agosto de 2005. Define normas nacionais para a ampliação do Ensino Fundamental para nove anos de duração. Brasília: CNE/CEB, 2005c. Disponível em: <portal.mec.gov.br>.

Parecer CNE/CEB n ${ }^{\circ} \mathbf{~ 1 8 / 2 0 0 5}$, aprovado em 15 de setembro de 2005. Orientações para a matrícula das crianças de 6 (seis) anos de idade no Ensino Fundamental obrigatório, em atendimento à Lei $\mathrm{n}^{\circ} 11.114$, de 16 de maio de 2005, que altera os Arts. $6^{\circ}, 32$ e 87 da Lei $\mathrm{n}^{\circ}$ 9.394/1996. Brasília: CNE/CEB, 2005d. Disponível em: <portal.mec.gov.br>.

Lei $\mathbf{n}^{\mathbf{0}} \mathbf{. 1 1 . 2 7 4}$, de 6 de fevereiro de 2006. Altera a redação dos arts. 29, 30, 32 e 87 da Lei n .9 .394 de 20 de dezembro de 1996, dispondo sobre a duração de 9 (nove) anos para o ensino fundamental, com matrícula obrigatória a partir dos 6 (seis) anos de idade. Brasília, 2006a. Disponível em: <http://www4.planalto.gov.br/legislacao>.

Parecer CNE/CEB no 39/2006, aprovado em 08 de agosto 2006. Consulta sobre situações relativas à matrícula de crianças de seis anos no Ensino Fundamental. Brasília: CNE/CEB, 2006b. Disponível em: <portal.mec.gov.br>.

Emenda Constitucional $\mathbf{n}^{\mathbf{0}}$ 53, de 19 de dezembro de 2006. Dá nova redação aos arts. $7^{\circ}, 23,30,206,208,211$ e 212 da Constituição Federal e ao art. 60 do Ato das Disposições Constitucionais Transitórias. Brasília, 2006c. Disponível em: $<$ http://www.planalto.gov.br>.

Parecer CNE/CEB n $\mathbf{0 5} / \mathbf{2 0 0 7}$, aprovado em $1^{\text {o }}$ de fevereiro de 2007. Consulta com base nas Leis $n^{\circ} 11.114 / 2005$ e $n^{\circ} 11.274 / 2006$, que tratam do Ensino Fundamental de nove anos e da matrícula obrigatória de crianças de seis anos no Ensino Fundamental. Brasília: CNE/CEB, 2007a. Disponível em: <portal.mec.gov.br>.

Parecer CNE/CEB no 07/2007, aprovado em 19 de abril de 2007. Reexame do Parecer CNE/CEB n $n^{\circ} 5 / 2007$, que trata da consulta com base nas Leis $n^{\circ} 1.114 / 2005$ e $n^{\circ}$ 11.274/2006, que se referem ao Ensino Fundamental de nove anos e à matrícula obrigatória de crianças de seis anos no Ensino Fundamental. Brasília: CNE/CEB, 2007b. Disponível em: $<$ portal.mec.gov.br>.

Lei no 11.494, de 20 de junho de 2007. Regulamenta o Fundo de Manutenção e Desenvolvimento da Educação Básica e de Valorização dos Profissionais da Educação - 
FUNDEB, de que trata o art. 60 do Ato das Disposições Constitucionais Transitórias; altera a Lei $\mathrm{n}^{\mathrm{o}}$ 10.195, de 2001; revoga dispositivos das Leis $\mathrm{n}^{\mathrm{os}} 9.424$ de 1996, 10.880 de 2004, e 10.845 de 2004; e dá outras providências. Brasília, 2007d. Disponível em: $<\mathrm{http}: / /$ www4.planalto.gov.br/legislacao $>$.

Ensino fundamental de nove anos: orientações para a inclusão da criança de seis anos de idade. $2^{a}$ Ed. Brasília: Ministério da Educação, Secretaria de Educação Básica, 2007c. Disponível em: <portal.mec.gov.br>.

Ensino Fundamental de nove anos: perguntas mais frequentes e respostas da Secretaria de Educação Básica. Brasília: Ministério da Educação, Secretaria de Educação Básica, 2007d. Disponível em: <portal.mec.gov.br>.

Parecer CNE/CEB n⿳0 04/2008, aprovado em 20 de fevereiro de 2008. Orientação sobre os três anos iniciais do Ensino Fundamental de nove anos. Brasília: CNE/CEB, 2008. Disponível em: <portal.mec.gov.br>.

Acervos complementares: as áreas do conhecimento nos dois primeiros anos do Ensino Fundamental. Brasília: Ministério da Educação, Secretaria de Educação Básica, 2009a. Disponível em: <portal.mec.gov.br>.

A criança de 6 anos, a linguagem escrita e o ensino fundamental de nove anos: orientações para o trabalho com a linguagem escrita em turmas de crianças de seis anos de idade. Brasília: Ministério da Educação, Secretaria de Educação Básica, 2009b

Ensino fundamental de nove anos: passo a passo do processo de implantação. $2^{\mathrm{a}}$ Ed. Brasília: Ministério da Educação, Secretaria de Educação Básica, 2009c.

Emenda Constitucional no . 59, de 11 de novembro de 2009. Brasília, 2009d. Disponível em: <www.planalto.gov.br>.

Parecer CNE/CEB no 22/2009, aprovado em 09 de dezembro de 2009. Diretrizes Operacionais para a implantação do Ensino Fundamental de 9 (nove) anos. Brasília: CNE/CEB, 2009e. Disponível em: <portal.mec.gov.br>.

Resolução CNE/CEB no. 1, de 14 de janeiro de 2010. Define Diretrizes Operacionais para a implantação do Ensino Fundamental de 9 (nove) anos. Brasília: CNE/CEB, 2010a. Disponível em: <portal.mec.gov.br>.

Parecer CNE/CEB no 11/2010, aprovado em 07 de julho de 2010. Define Diretrizes Curriculares Nacionais para o Ensino Fundamental de 9 (nove) anos. Brasília: CNE/CEB, 2010b. Disponível em: <portal.mec.gov.br>.

Resolução CNE/CEB nº. 7, de 14 de dezembro de 2010. Fixa Diretrizes Curriculares Nacionais para o Ensino Fundamental de 9 (nove) anos. Brasília: CNE/CEB, 2010c. Disponível em: <portal.mec.gov.br>.

Lei $\mathbf{n}^{\mathbf{0}}$. 12.796, de 4 de abril de 2013. Altera a Lei $\mathrm{n}^{\mathrm{o}}$ 9.394, de 20 de dezembro de 1996, que estabelece as diretrizes e bases da educação nacional, para dispor sobre a formação dos profissionais da educação e dar outras providências. 
Brasília, 2013. Disponível em: <http://www4.planalto.gov.br/legislacao>.

BUENO, M. L. M. C. Ensino fundamental de nove anos: implementação e organização escolar em Dourados/MS. Dissertação (Mestrado em Educação). Universidade Federal da Grande Dourados - UFGD, Dourados/MS, 2010.

CAMPOS, M. M. O ensino fundamental de nove séries e as crianças de seis anos. Nuances: estudos sobre Educação. Presidente Prudente, SP, ano XIII, v. 14, n. 15, p. 19-27, jan./dez. 2007.

CAPUCHINHO, A. O. Significados e sentidos produzidos pelo professor sobre o Ensino Fundamental de nove anos. Dissertação (Mestrado em Educação: Psicologia da Educação). Pontifícia Universidade Católica de São Paulo, São Paulo, 2007.

CARNEIRO, F. H. P. Caminhos da alfebetização em Minas: um olhar etnográfico para o ciclo inicial de alfabetização. Dissertação (Mestrado em Educação). Universidade Federal de Minas Gerais, Belo Horizonte, 2006.

CHAVES, S. S. Implementação do ensino fundamental de nove anos em uma escola municipal de salvador: processo participativo ou força da lei?. Dissertação (Mestrado em Educação). Universidade Federal da Bahia, Salvador, 2012.

CORREA, B. C. Considerações sobre qualidade na educação infantil. Cadernos de Pesquisa, São Paulo, no. 119, p. 85-112, 2003.

Crianças aos seis anos no ensino fundamental: desafios à garantia de direitos. In: Reunião Anual da ANPED, 30a . 2007. Disponível em: http://www.anped.org.br. Acesso em 15 de outubro de 2011.

Ensino fundamental de nove anos: análise de uma experiência no interior do estado de São Paulo. In: Reunião Anual da ANPED, 33ª 2010. Disponível em: http://www.anped.org.br. Acesso em 15 de outubro de 2011.

Educação Infantil e ensino fundamental: desafios e desencontros na implantação de uma nova política. Educação e Pesquisa. São Paulo, v.37, n.1, jan./abr, 2011a.

Políticas de educação infantil no Brasil: ensaio sobre os desafios para a concretização de um direito. Jornal de Políticas Educacionais, nº 19, jan-jun 2011b.

CORRÊA, R. C. P. "Vamos brincar?": continuidades e rupturas nas práticas curriculares da educação infantil e dos anos iniciais do ensino fundamental. Dissertação (Mestrado em Educação). Universidade do Vale de Itajaí - UNIVALI, Itajaí (SC), 2011.

COSTA, S. S. Ensino Fundamental de nove anos em Goiânia: o lugar da criança de seis anos, concepções e fundamentos sobre sua educação. 2009. 250 f. Tese (Doutorado em Educação) - Faculdade de Educação, Universidade Federal de Goiás, Goiânia, 2009.

CORSINO, P. As crianças de seis anos e as áreas do conhecimento. In: BRASIL. Ensino fundamental de nove anos: orientações para a inclusão da criança de seis anos de idade. $2^{\mathrm{a}}$ Ed. Brasília: Ministério da Educação, Secretaria de Educação Básica, 2007c. 
CRAIDY, C. M.; BARBOSA, M. C. S. Ingresso obrigatório no ensino fundamental aos 6 anos: falsa solução para um falso problema. In: BARBOSA, M. C. S.; DELGADO, A. C. C. (Orgs). A Infância no Ensino Fundamental de 9 anos. Porto Alegre, RS: Penso, 2012.

CURY, C. R. J. A educação básica como direito. Cadernos de Pesquisa, v. 38, n. 134, p. 293-303, maio/ago. 2008.

DANTAS, A. G. Ensino fundamental de nove anos no Distrito Federal: reflexões sobre a inserção de crianças de seis anos no ensino público e a atuação docente. Dissertação (Mestrado em Processos de Desenvolvimento e Saúde). Universidade de Brasília - UNB, Brasília, 2009.

DELFIN, A. S. A inclusão de crianças de 6 anos no Ensino Fundamental: um estudo do brincar à luz das Políticas Públicas de Educação. Dissertação (Mestrado em Educação). Universidade Cidade de São Paulo, São Paulo, 2012.

DORNELLES, L. V. Os alfabetizados-desviantes ou sobre a educação dos 6 anos. Educação e Pesquisa, São Paulo, v.37, n.1, 220p. 141-155, jan./abr. 2011.

FERREIRA, V. L. A alfabetização e a implantação do ensino fundamental de nove anos no município de Jaguarão/RS. Dissertação (Mestrado em Educação). Universidade Federal de Pelotas, Pelotas (RS), 2011.

FLACH, S. F. O direito à educação e sua relação com a ampliação da escolaridade obrigatória no Brasil. Ensaio: Avaliação e Políticas Públicas em Educação, v. 17, n. 64, p. 495-520, 2009.

FONTES, V. L. A escola de 9 anos, características e impactos por meio de representações parentais: um estudo na rede municipal de ensino de Araraquara. Dissertação (Mestrado em Educação). Pontifícia Universidade Católica de São Paulo, São Paulo, 2009.

FURTADO, M. T. C. A infância no processo de reorganização curricular do ensino fundamental de nove anos na escola: um estudo de caso. 2009. Dissertação (Mestrado em Educação), Universidade do Vale de Itajaí - UNIVALI, Itajaí (SC), 2009.

GALVÃO, C. M.; SAWADA, N. O; TREVIZAN, M. A. Revisão sistemática: recurso que proporciona a incorporação das evidências na prática da enfermagem. Revista LatinoAmericana de Enfermagem, v.12, n.3, p. 549-556, 2004.

GARCIA, Y. N. B. F. Uma criança pequena em uma escola de grandes: sentimentos e emoções no ingresso do ensino fundamental de nove anos. Dissertação (Mestrado em Educação: Psicologia da Educação). Pontifícia Universidade Católica de São Paulo - PUCSP, São Paulo, 2012.

GIL, L. G. Implementação de Políticas Públicas: um estudo de caso sobre a ampliação do ensino fundamental para nove anos no município de São Bernardo do Campo. Dissertação (Mestrado em Educação). Universidade de São Paulo, São Paulo, 2012. 
GORNI, D. A. P. Ensino Fundamental de 9 anos: estamos preparados para implantá-lo?. Ensaio: Avaliação e Políticas Públicas em Educação, v. 15, n. 54, p. 67-80, 2007.

GOHN, M. G. M. Lutas e movimentos pela Educação no Brasil a partir de 1970. EccoS Revista Científica, São Paulo, v. 11, n. 1, p. 23-38., jan./jun. 2009,

GUIMARÃES, J. L.; PINTO, J. M. R. A Demanda pela educação infantil e os recursos disponíveis para seu financiamento. Em aberto, v. 18, n. 74, p. 12-105, jul. 2001.

HASHIMOTO, C. I. Ensino fundamental de nove anos: um novo caminho em velha estrada? Um velho caminho em nova estrada?. Tese (Doutorado). Pontifícia Universidade Católica de São Paulo, São Paulo, 2012.

HEINIG, O. L. O. M. Alfabetização e letramento no cenário escolar: compreensões de gestores educacionais. Perspectiva, Florianópolis, v. 28, n. 2, 509-540, jul./dez. 2010.

INSTITUTO Nacional de Estudos e Pesquisas Educacionais Anísio Teixeira (INEP). Censo escolar de 2011 - Resumo técnico. Brasília, 2011. Disponível em:

$<$ http://download.inep.gov.br/educacao_basica/censo_escolar/resumos_tecnicos/resumo_tecni co_censo_educacao_basica_2011.pdf>. Acesso em 9 de nov de 2012.

JACOMINI, M. A.; KLEIN, S. B. Qualidade da educação e Ensino Fundamental de nove anos: algumas reflexões. Revista @ mbienteeducação, São Paulo , v. 3, n. 1, p. 75- 92, jan./jun. 2010.

JACOMINI, M. A.; ROSA, C. O.; ALENCAR, F. W. F. Direito, qualidade e gestão da educação no ensino fundamental de nove anos na rede municipal de Diadema. Revista de Educação PUC-Campinas, Campinas, v. 17, n. 2, p 229-239, jul./dez. 2012.

KISHIMOTO, T. M.; PINAZZA, M. A.; MORGADO, R. F. C.; TOYOFUKI, K. R. Jogo e letramento: crianças de 6 anos no ensino fundamental. Educação e Pesquisa, São Paulo, v.37, n.1, p. 191-210, jan./abr. 2011.

KLEIN, S. B. Ensino fundamental de nove anos no município de São Paulo: um estudo de caso. Dissertação (Mestrado em Educação). Universidade de São Paulo, São Paulo, 2011.

KRAMER, S. As crianças de 0 a 6 anos nas políticas educacionais no Brasil: educação infantil e/é fundamental. Educação e Sociedade, Campinas, v. 27, n. 96, p.797-818, out. 2006.

KRAMER, S; NUNES, M. F. R; CORSINO, P. Infância e crianças de seis anos: desafios das transições na educação infantil e no ensino fundamental. Educação e Pesquisa, São Paulo, v. 37, n. 1, p. 69-85, jan./abr. 2011.

LEAL, M. P. S. L. Ensino Fundamental de 9 (nove) anos: a universalização do acesso, a permanência qualitativa na escola e as contradições do processo de implantação em São Luís. Dissertação (Mestrado em Educação). Universidade Federal do Maranhão, São Luís, 2011. 
LIMA, L. A. Ensino fundamental de nove anos: repercussões da lei $\mathrm{n}^{\mathrm{o}}$ 11.274/2006 na proposta curricular da rede municipal de ensino de Juiz de Fora. Dissertação (Mestrado em Educação). Universidade Federal de Juiz de Fora, Juiz de Fora, 2011.

LOUREIRO, C. C. O ensino fundamental de nove anos e o colégio de aplicação: da "prontidão" a emergência da infância. Dissertação (Mestrado em Educação). Universidade Federal de Santa Catarina, Florianópolis (SC), 2010.

MACHADO, V. L. C. A implantação do ensino fundamental de nove anos em escolas municipais de Campinas/SP: o olhar dos gestores. In: Reunião Anual da ANPED, $33^{\mathrm{a}}$. 2010. Disponível em: http://www.anped.org.br. Acesso em 15 de outubro de 2011.

MAIA, G. Z. A; CAMILLO, C. V. Ensino Fundamental de Nove Anos: um estudo da percepção das equipes de direção de escolas públicas de um município do Estado de São Paulo. Práxis Educativa, Ponta Grossa, v.4, n.2, p.149-157, jul.-dez. 2009.

MALTA, M. O ensino fundamental de nove anos: reflexões sobre o currículo e a prática pedagógica. Dissertação (Mestrado em Educação). Centro Universitário Moura Lacerda, Ribeirão Preto, 2012.

MARCELLO, F. A.; BUJES, M. I. E. A. Ampliação do ensino fundamental: a que demandas atende? A que regras obedece? A que racionalidades corresponde? Educação e Pesquisa, São Paulo, v. 37, n. 1, p. 53-68, jan/abr. 2011.

MARCONDES, K. H. B. Continuidades e descontinuidades na transição da Educação Infantil para o Ensino Fundamental no contexto de nove anos. Tese (Doutorado em Educação) - Universidade Estadual Paulista, Araraquara, 2012.

MASCIOLI, S. A. Z. Cotidiano escolar e infância: interfaces da educação infantil e do ensino fundamental nas vozes de seus protagonistas. Tese (Doutorado em Educação Escolar). Universidade Estadual Paulista, Araraquara, 2012.

MAREGA, M. A. P. A criança de seis anos na escola: transição da atividade lúdica para a atividade de estudo. Dissertação (Mestrado em Educação). Universidade Estadual de Maringá, Maringá (PR), 2010.

MIRANDA, A. P. A. D. Letramento e alfabetização: resgate do papel do professor no ato de aprender e ensinar. Dissertação (Mestrado em Educação). Universidade de São Paulo, São Paulo, 2012.

MORO, C. S. Ensino fundamental de 9 anos: o que dizem os professores do $1^{\circ}$ ano. Tese (Doutorado em Educação). Universidade Federal do Paraná, Curitiba, 2009.

MORAES, A. C. Ensino fundamental de nove anos: a docência em escolas da rede municipal de São Carlos. Tese (Doutorado em Educação). Universidade Federal de São Carlos, São Carlos, 2012.

MOTA, M. R. A. As crianças de seis anos no ensino fundamental de nove anos e o governamento da infância. Tese (Doutorado em Educação) - Universidade Federal do Rio Grande do Sul, Porto Alegre, 2010. 
MOTTA, D. J. L. Ampliação do ensino fundamental: compreendendo o fazer do professor. Dissertação (Mestrado em Psicologia). Universidade Estadual Paulista Júlio de Mesquita Filho - Unesp, Assis (SP), 2009.

MOYA, D. J. L. Criança de seis anos de idade no ensino fundamental: práticas e perspectivas. 2009. Dissertação (Mestrado em Educação) - Universidade Estadual de Maringá, Maringá.

NASCIMENTO, A. M. A infância na escola e na vida: uma relação fundamental. In: BRASIL. Ensino fundamental de nove anos: orientações para a inclusão da criança de seis anos de idade. $2^{a}$ Ed. Brasília: Ministério da Educação, Secretaria de Educação Básica, 2007c.

NOGUEIRA, G. M. A passagem da Educação Infantil para o $1^{\circ}$ ano no contexto do Ensino Fundamental de nove anos: um estudo sobre alfabetização, letramento e cultura lúdica. Tese (Doutorado em Educação). Universidade Federal de Pelotas, Pelotas, 2011.

NOGUEIRA, A. L. H.; CATANANTE. I. T. Trabalho docente e desenvolvimento das atividades simbólicas: considerações para o ensino fundamental de nove anos. Educação e Pesquisa, São Paulo, v.37, n.1, p. 175-190, jan./abr. 2011.

OLIVEIRA, D. L. A implantação do ensino fundamental de nove anos no estado do Paraná. 2009. Dissertação (Mestrado em Educação) - Universidade Estadual de Ponta Grossa, Ponta Grossa, 2009.

OLIVEIRA, D. R. A formação continuada de professores de primeiro ano do ensino fundamental de nove anos e os desafios ao trabalho pedagógico. Dissertação (Mestrado em Educação) - Universidade Estadual Paulista, Presidente Prudente, 2011.

OLIVEIRA, S. M. P. O ingresso no ensino fundamental com cinco anos: direito à escolarização ou negação do direito à infância?. Disponível em: <http://www.mprs.mp.br/infancia/doutrina/id694.htm>. S/d.

OLIVEIRA, R. F.; TEIXEIRA, B. B. Do FUNDEF ao FUNDEB: a qualidade ainda fora de pauta. Disponível em:

$<$ http://www.ufsj.edu.br/portal-repositorio/File/Vertentes/Rosimar\%20e\%20Beatriz.pdf>.

PANSINI, F.; MARIN, A. P. O ingresso de crianças de 6 anos no ensino fundamental: uma pesquisa em Rondônia. Educação e Pesquisa, v.37, n.1, pp. 87-103, 2011.

PARO, V.H. Educação como exercício do poder: crítica ao senso comum em educação. 2. ed. São Paulo: Cortez, 2010.

PEREIRA, L. H. P.; BONFIN, P. V. Brincar e aprender: um novo olhar para o lúdico no primeiro ano do Ensino Fundamental. Revista Educação, v. 34, n. 2, p 295-309, maio/ago 2009.

PINTO, J. M. R. . Um fundinho chamado “fundão”. In: DOURADO, L. F. (Org.).

Financiamento da educação básica. $1^{a}$ ed. Campinas: Autores Associados, v. 1, p. 85-98, 1999. 
PINTO, J. M. R. Os recursos para a educação no Brasil no contexto das finanças públicas. Brasília: Editora Plano, 2000.

PINTO, J. M. R. A política recente de fundos para o financiamento da educação e seus efeitos no pacto federativo. Educação e Sociedade, Campinas, v. 28, n. 100 - Especial, p. 877-897, out. 2007 Disponível em: <http://www.cedes.unicamp.br>

PINTO, J. M. R.; ALVES, T. Ampliação da obrigatoriedade na educação básica: como garantir o direito sem comprometer a qualidade? Retratos da Escola, Brasília, v. 4, n. 7, p. 211-229, jul./dez. 2010. Disponível em: <http//www.esforce.org.br>.

PINTO, J. M. R.; ALVES, T. O impacto financeiro da obrigatoriedade escolar no contexto do Fundeb. Educação e Realidade, Porto Alegre, v. 36, n. 2, p. 605-624, maio/ago. 2011. Disponível em: <http://seer.ufrgs.br/educacaoerealidade/article/view/15128>.

PURIM, R. F. Um ano mais cedo ou um ano a mais: representação social de curricular de professores alfabetizadores no ensino fundamental ampliado. 2009. Dissertação (Mestrado em Educação), Universidade Regional de Blumenau (FURB), Blumenau (SC), 2009.

RANIRO, C. Um retrato do primeiro ano do ensino fundamental: o que revelam crianças, pais e professoras. Dissertação (Mestrado em Educação Escolar). Faculdade de Ciências e Letras, Universidade Estadual Paulista, Araraquara, 2009.

ROCHA, M. S. P. M. L. A atividade lúdica, a criança de 6 anos e o ensino fundamental. Psicologia Escolar e Educacional, v. 13, n. 2, p. 203-212, dez. 2009.

"Parece um prezinho": famílias de classes populares e o novo ensino fundamental. Psicologia em estudo, v.15, n.3, pp. 487-496, 2010.

ROCHA, I. L. O Ensino Fundamental de nove anos no estado de Alagoas: um estudo da efetivação da política de implantação a partir da experiência do Município de Delmiro Gouveia - AL. Dissertação (Mestrado em Educação Brasileira). Universidade Federal de Alagoas, Maceió (AL), 2012.

ROSA, M. M. Políticas Municipais de Educação Infantil: desafios à gestão local a partir da implantação do ensino fundamental de nove anos. Dissertação (Mestrado em Educação). Universidade do Oeste de Santa Catarina, Joaçaba (SC), 2011.

ROSAR, M. F. F. Educação e movimentos sociais: avanços e recuos entre o século XX e o século XXI. Educação em Revista, Marília, v. 12, n. 2, p. 145-162, jul./dez 2011.

ROSEMBERG, F. A educação pré-escolar obrigatória: versão preliminar. In: Reunião Anual da Anped, 32a , 2009. Caxambu: ANPED, 2009. (Trabalho encomendado pelo Grupo de Trabalho Educação de Crianças de 0 a 6 anos).

ROSEMBERG, F. Educação infantil pós-FUNDEB: avanços e tensões. In: SOUZA, G. (Org.). Educar na Infância: perspectivas histórico-sociais. São Paulo: Contexto, 2010. 
SAMPAIO, R. F.; MANCINI, M. C. Estudos de revisão sistemática: um guia para síntese criteriosa da evidência científica. Revista brasileira de fisioterapia, vol.11, n.1, pp. 83-89, 2007.

SAMWAYS, A. M. Ensino fundamental de nove anos: dimensões políticas e pedagógicas. Dissertação (Mestrado em Educação). Universidade Estadual de Ponta Grossa, Ponta Grossa (PR), 2012.

SANT'ANNA, I. M.; GUZZO, R. S. L. A escola de nove anos e a atuação docente: análise de uma experiência na escola pública. Psicologia da Educação, São Paulo, 28, $1^{\circ}$ sem. de 2009, pp. 91-108.

SANTOS, L. L. Diretrizes curriculares nacionais para o ensino fundamental de 9 anos e o Plano Nacional de Educação: abrindo a discussão. Educação e sociedade. Campinas, SP, v.31, n. 112, p.833-850, set 2010. Disponível em:

$<$ http://www.scielo.br/pdf/es/v31n112/10.pdf>.

SANTOS, L. L. C. P.; VIEIRA, L. M. F. "Agora seu filho entra mais cedo na escola": a criança de seis anos no ensino fundamental de nove anos em Minas Gerais. Educação e Sociedade, v. 27, n. 96, p. 775-796, 2006.

SAVELI, E. L. Ensino fundamental de nove anos: bases legais de sua implantação. Práxis Educativa, v. 3, n. 1, p. 67-72, 2009.

SAVIANI, D. Da nova LDB ao FUNDEB: por uma outra política educacional. 4. ed. Campinas: Autores Associados, 2011.

SCALZITTI, C. M. K. Linguagem e infância: relações com o letramento. Dissertação (Mestrado). Universidade Federal do Mato Grosso, Cuiabá (MT), 2012.

SCHMITZ, L. L. Entre a educação infantil e o ensino fundamental: uma análise das vivências espaço-temporais das infâncias. Dissertação (Mestrado em Educação). Universidade Regional do Noroeste do Estado do Rio Grande do Sul, Ijuí (RS), 2008.

SILVA, A. A.; SCAFF, E. A. S. O ensino fundamental de nove anos como política de integração social: análises a partir de dois estados brasileiros. In: Reunião Anual da ANPED, 32a . 2009. Disponível em: http://www.anped.org.br. Acesso em 15 de outubro de 2011.

SILVA, D. D. Construção dos conteúdos para o primeiro ano do Ensino Fundamental de nove anos a partir de conhecimentos sobre a língua materna de professores em exercício e de propostas governamentais. Dissertação (Mestrado em Educação). Universidade Federal de São Carlos, São Carlos, 2008.

SILVA, J. S. O planejamento no enfoque emergente: uma experiência no $1^{\circ}$ ano do ensino fundamental de nove anos. Tese (Doutorado em Educação). Faculdade de Educação, Universidade Federal do Rio Grande do Sul, Porto Alegre, 2011. 
SILVA, P. A. A dimensão complexa das políticas públicas para a educação: o ensino fundamental de nove anos. Dissertação (Mestrado em Educação). Universidade de Brasília, Brasília, 2012.

SILVA, R. A implementação do ensino fundamental de nove anos e seus efeitos para a educação infantil: um estudo em municípios catarinenses. 2009. Dissertação (Mestrado em Educação). Universidade Federal de Santa Catarina, Florianópolis, 2009.

SILVA, T. F. A aprendizagem e a prática pedagógica no $1^{\circ}$ ano do ensino fundamental. Dissertação (Mestrado em Educação). Pontifícia Universidade Católica do Paraná - PUC-PR, Curitiba (PR), 2010.

SOUZA, K. R. A reorganização do ensino fundamental de nove anos a partir do projeto político pedagógico das escolas. Dissertação (Mestrado em Educação). Universidade Federal da Grande Dourados, Dourados (MS), 2012.

STURION, F. O ensino fundamental de nove anos: o que revelam professores em seus discursos. Dissertação (Mestrado em Educação). Universidade Metodista de Piracicaba UNIMEP, Piracicaba (SP), 2010.

TASCA, D. S. O. Alfabetizar, Letrar - Práticas alfabetizadoras no contexto da escola organizada em ciclos. Dissertação (Mestrado em Educação). Universidade Estadual de Campinas - UNICAMP, Campinas (SP), 2010.

TENREIRO, M.O.V. Ensino fundamental de nove anos: o impacto da política na escola. 2011. Tese (Doutorado em Educação). Pontifícia Universidade Católica de São Paulo, São Paulo, 2011.

THOMÉ, A. C. M. B. Ensino Fundamental de Nove Anos: dificuldades enfrentadas e aprendizados construídos por gestores e professores. Dissertação (Mestrado em Ciências). Universidade de São Paulo, Ribeirão Preto (SP), 2011.

TOLENTINO, M. A. H. Educação continuada e trabalho docente no bloco inicial de alfabetização: o caso de uma escola da rede pública do Distrito Federal. Dissertação (Mestrado em Educação). Universidade de Brasília - UNB, Brasília, 2007.

TOSCANO, C.; SAITO, H. T. I. A prática docente no $1^{\circ}$ ano do ensino fundamental e o ensino de ciências: um estudo de caso. Ciências \& Cognição, v. 14, n. 2, p. 147-165, 2009.

VARGAS, J. C. Professoras alfabetizadoras e o ensino fundamental de nove anos: concepções frente à infância e à ludicidade. 2010. Dissertação (Mestrado em Educação). Universidade Federal de Santa Maria, Santa Maria.

VIEIRA, L. C. O Ensino Fundamental de nove anos no Brasil: meandros políticopedagógicos de sua implementação. Revista Eletrônica Política e Gestão Educacional, n. 6, 2009. 
ANEXOS 


\title{
ANEXO 1 \\ LEI № 11.114, DE 16 DE MAIO DE 2005.
}

Mensagem de veto

Altera os arts. $6^{\circ}, 30,32$ e 87 da Lei $n^{\circ} 9.394$, de 20 de dezembro de 1996, com o objetivo de tornar obrigatório o início do ensino fundamental aos seis anos de idade.

\begin{abstract}
O PRESIDENTE DA REPÚBLICA Faço saber que o Congresso Nacional decreta e eu sanciono a seguinte Lei:
\end{abstract}

Art. $1^{\circ}$ Os arts. $6^{\circ}, 30,32$ e 87 da Lei $n^{\circ} 9.394$, de 20 de dezembro de 1996 , passam a vigorar com a seguinte redação:

"Art. $6^{\circ}$. É dever dos pais ou responsáveis efetuar a matrícula dos menores, a partir dos seis anos de idade, no ensino fundamental." (NR)

"Art. 30.

II - (VETADO)"

"Art. $32^{\circ}$. O ensino fundamental, com duração mínima de oito anos, obrigatório e gratuito na escola pública a partir dos seis anos, terá por objetivo a formação básica do cidadão mediante:

." (NR)

"Art. 87.

$\S 3^{0}$

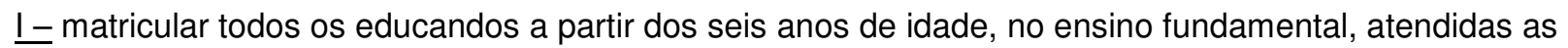
seguintes condições no âmbito de cada sistema de ensino:

a) plena observância das condições de oferta fixadas por esta Lei, no caso de todas as redes escolares;

b) atingimento de taxa líquida de escolarização de pelo menos 95\% (noventa e cinco por cento) da faixa etária de sete a catorze anos, no caso das redes escolares públicas; e

c) não redução média de recursos por aluno do ensino fundamental na respectiva rede pública, resultante da incorporação dos alunos de seis anos de idade;

." (NR)

Art. $2^{\circ}$ Esta Lei entra em vigor na data de sua publicação, com eficácia a partir do início do ano letivo subseqüente.

Brasília, 16 de maio de 2005; $184^{\circ}$ da Independência e $117^{\circ}$ da República.

LUIZ INÁCIO LULA DA SILVA

Tarso Genro

Álvaro Augusto Ribeiro Costa 


\section{ANEXO 2}

\section{LEI № 11.274, DE 6 DE FEVEREIRO DE 2006.}

Altera a redação dos arts. 29, 30,32 e 87 da Lei
Mensagem de veto
no.394, de 20 de dezembro de 1996, que
estabelece as diretrizes e bases da educação
nacional, dispondo sobre a duração de 9 (nove) anos
para o ensino fundamental, com matrícula obrigatória
a partir dos 6 (seis) anos de idade.

O PRESIDENTE DA REPÚBLICA Faço saber que o Congresso Nacional decreta e eu sanciono a seguinte Lei:

Art. $1^{\circ}$ (VETADO)

Art. $3^{\circ} \mathrm{O}$ art. 32 da Lei $n^{\circ} 9.394$, de 20 de dezembro de 1996, passa a vigorar com a seguinte redação:

"Art. 32. O ensino fundamental obrigatório, com duração de 9 (nove) anos, gratuito na escola pública, iniciando-se aos 6 (seis) anos de idade, terá por objetivo a formação básica do cidadão, mediante:

" (NR)

Art. $4^{\circ} \mathrm{O} \S 2^{\circ}$ e o inciso I do $\S 3^{\circ}$ do art. 87 da Lei $n^{\circ} 9.394$, de 20 de dezembro de 1996 , passam a vigorar com a seguinte redação:

"Art. 87

$\S 2^{\circ}$ O poder público deverá recensear os educandos no ensino fundamental, com especial atenção para o grupo de 6 (seis) a 14 (quatorze) anos de idade e de 15 (quinze) a 16 (dezesseis) anos de idade.

$\S 3^{\circ}$

I - matricular todos os educandos a partir dos 6 (seis) anos de idade no ensino fundamental;

a) (Revogado)

b) (Revogado)

c) (Revogado) .." (NR)

Art. $5^{\circ}$ Os Municípios, os Estados e o Distrito Federal terão prazo até 2010 para implementar a obrigatoriedade para o ensino fundamental disposto no art. $3^{\circ}$ desta Lei e a abrangência da pré-escola de que trata 0 art. $2^{\circ}$ desta Lei.

Art. $6^{\circ}$ Esta Lei entra em vigor na data de sua publicação.

Brasília, 6 de fevereiro de 2006; $185^{\circ}$ da Independência e $118^{\circ}$ da República.

LUIZ INÁCIO LULA DA SILVA

Márcio Thomaz Bastos

Fernando Haddad

Álvaro Augusto Ribeiro Costa 


\title{
ANEXO 3
}

\section{MENSAGEM № 65, DE 6 DE FEVEREIRO DE 2006.}

\author{
Senhor Presidente do Senado Federal,
}

Comunico a Vossa Excelência que, nos termos do $\S 1^{0}$ do art. 66 da Constituição, decidi vetar parcialmente, por inconstitucionalidade, o Projeto de Lei $n^{\circ}$ 144, de 2005 ( $n^{\circ}$ 3.675/04 na Câmara dos Deputados), que "Altera a redação dos arts. 29, 30, 32 e 87 da Lei no 9.394, de 20 de dezembro de 1996, que estabelece as diretrizes e bases da educação nacional, dispondo sobre a duração de 9 (nove) anos para o ensino fundamental, com matrícula obrigatória a partir dos 6 (seis) anos de idade".

Ouvida, a Advocacia-Geral da União, manifestou-se pelo veto aos seguintes dispositivos:

\section{Art. 29 da Lei $n^{\circ} 9.394$, de 1996, alterado pelo art. $1^{\circ}$ do projeto de lei}

"Art. 29. A educação infantil, primeira etapa da educação básica, tem como finalidade o desenvolvimento integral da criança até 5 (cinco) anos de idade, em seus aspectos físico, psicológico, intelectual e social, complementando a ação da família e da comunidade." (NR)

\section{Inciso II do art. 30 da Lei $n^{\circ} 9.394$, de 1996 , alterado pelo art. $2^{\circ}$ do projeto de lei}

"Art. 30.

II - pré-escolas, para crianças de 4 (quatro) e 5 (cinco) anos de idade." (NR)

\section{Razões do veto}

"De acordo com o art. 208, incisos I e IV, da Constituição, o dever do Estado com a educação será efetivado mediante a garantia de ensino fundamental obrigatório e gratuito, assegurada, inclusive, sua oferta gratuita para todos os que a ele não tiverem acesso na idade própria e atendimento em creche e pré-escola às crianças de zero a seis anos de idade. A previsão constitucional de atendimento em creches e pré-escolas está reproduzida no art. $4^{\circ}$ inciso IV, da Lei $n^{\circ} 9.394$, de 1996 , que não foi alterado no presente projeto de lei.

Em assim sendo, e tendo em vista que a educação infantil abrange as creches e pré-escolas, não há como aceitar as alterações sugeridas aos arts. 29 e 30 da Lei no 9.394 , de 1996 , constantes do art. $1^{\circ}$ e $2^{\circ}$ do projeto de lei, que destoam do dispositivo constitucional acima mencionado. Não há que se falar sequer em adequação à lei em vigor, porque 0 art. $4^{\circ}$ desta, acima referido, continuará com redação idêntica à constitucional."

Essas, Senhor Presidente, as razões que me levaram a vetar os dispositivos acima mencionados do projeto em causa, as quais ora submeto à elevada apreciação dos Senhores Membros do Congresso Nacional. 


\section{ANEXO 4}

\section{Relação dos trabalhos analisados na revisão de literatura.}

\section{TESES:}

\begin{tabular}{|l|l|c|}
\hline \multicolumn{1}{|c|}{ Título do trabalho } & \multicolumn{1}{|c|}{ Nome do autor } & Ano \\
\hline $\begin{array}{l}\text { Ensino fundamental de nove anos em Goiânia: o lugar da } \\
\text { criança de seis anos, concepções e fundamentos sobre sua } \\
\text { educação. }\end{array}$ & $\begin{array}{l}\text { Sônia Santana da Costa } \\
\text { (COSTA, S. S.) }\end{array}$ & 2009 \\
\hline $\begin{array}{l}\text { Ensino fundamental de nove anos: um novo caminho em velha } \\
\text { estrada? Um velho caminho em nova estrada? }\end{array}$ & $\begin{array}{l}\text { Cecília I. Hashimoto } \\
\text { (HASHIMOTO, C. I.) }\end{array}$ & 2012 \\
\hline $\begin{array}{l}\text { Continuidades e descontinuidades na transição da Educação } \\
\text { Infantil para o Ensino Fundamental no contexto de nove anos } \\
\text { de duração. }\end{array}$ & $\begin{array}{l}\text { Keila Hellen Barbato Marcondes } \\
\text { (MARCONDES, K. H. B) }\end{array}$ & 2012 \\
\hline $\begin{array}{l}\text { Cotidiano Escolar e Infância: interfaces da Educação Infantil e } \\
\text { do Ensino Fundamental nas vozes de seus protagonistas. }\end{array}$ & $\begin{array}{l}\text { Suselaine A. Zaniolo Mascioli } \\
\text { (MASCIOLI, S. A. Z.) }\end{array}$ & 2012 \\
\hline $\begin{array}{l}\text { Ensino fundamental de nove anos: a docência em escolas da } \\
\text { rede municipal de São Carlos. }\end{array}$ & $\begin{array}{l}\text { Alessandra Cardoso de Moraes } \\
\text { (MORAES, A. C.) }\end{array}$ & 2012 \\
\hline $\begin{array}{l}\text { A passagem da educação infantil para o 1 }{ }^{\circ} \text { ano no contexto do } \\
\text { ensino fundamental de nove anos: um estudo sobre } \\
\text { alfabetização, letramento e cultura lúdica. }\end{array}$ & $\begin{array}{l}\text { Gabriela Medeiros Nogueira } \\
\text { (NOGUEIRA, G. M.) }\end{array}$ & 2011 \\
\hline $\begin{array}{l}\text { O planejamento no enfoque emergente: uma experiência no 1 } \\
\text { ano do ensino fundamental de nove anos. }\end{array}$ & $\begin{array}{l}\text { Jacqueline Silva da Silva } \\
\text { (SILVA, J. S.) }\end{array}$ & $\begin{array}{l}\text { Maria Odete Vieira Tenreiro } \\
\text { (TENREIRO, M. O. V.) }\end{array}$ \\
\hline $\begin{array}{l}\text { Ensino fundamental de nove anos: o impacto da política na } \\
\text { escola. }\end{array}$ & 2011 \\
\hline
\end{tabular}

\section{DISSERTAÇÕES:}

\begin{tabular}{|l|l|c|}
\hline \multicolumn{1}{|c|}{ Título do trabalho } & \multicolumn{1}{c|}{ Nome do autor } & Ano \\
\hline $\begin{array}{l}\text { O ingresso no } 1^{\text {o }} \text { ano do ensino fundamental de nove anos: } \\
\text { sentimentos revelados por crianças de uma escola pública. }\end{array}$ & $\begin{array}{l}\text { Ludmila Passos Abreu } \\
\text { (ABREU, L. P.) }\end{array}$ & 2010 \\
\hline $\begin{array}{l}\text { Ensino fundamental de nove anos no município de } \\
\text { Uberlândia: implicações no processo de alfabetização e } \\
\text { letramento. }\end{array}$ & $\begin{array}{l}\text { Márcia Martins de Oliveira Abreu } \\
\text { (ABREU, M. M. O) }\end{array}$ & 2009 \\
\hline $\begin{array}{l}\text { O que é ser criança e viver a infância na escola: uma análise } \\
\text { da transição da educação infantil para o ensino fundamental } \\
\text { numa escola municipal de Curitiba. }\end{array}$ & $\begin{array}{l}\text { Arleandra Cristina Talin do Amaral } \\
\text { (AMARAL, A. C. T.) }\end{array}$ & 2008 \\
\hline $\begin{array}{l}\text { Ensino fundamental de nove anos: em busca da legitimação } \\
\text { no cotidiano escolar. }\end{array}$ & $\begin{array}{l}\text { Jucemara Antunes } \\
\text { (ANTUNES, J.) }\end{array}$ & 2010 \\
\hline $\begin{array}{l}\text { Construindo sentidos para a inclusão das crianças de seis } \\
\text { anos de idade no ensino fundamental de nove anos: um } \\
\text { diálogo com professores. }\end{array}$ & $\begin{array}{l}\text { Rita de Cássia Barros de Freitas } \\
\text { Araújo } \\
\text { (ARAÚJO, R. C. B. F.) }\end{array}$ & 2008 \\
\hline $\begin{array}{l}\text { A implementação do 1 } \text { ano no ensino fundamental de nove } \\
\text { anos: estudo de uma experiência. }\end{array}$ & $\begin{array}{l}\text { Mara Silvia Paes Barbosa } \\
\text { (BARBOSA, M. S. P.) }\end{array}$ & 2009 \\
\hline $\begin{array}{l}\text { Mudanças e continuidades da cultura da escola no contexto } \\
\text { de implantação do Ensino Fundamental de nove anos. }\end{array}$ & $\begin{array}{l}\text { Delma Rosa dos Santos Bezerra } \\
\text { (BEZERRA, D. R. S.) }\end{array}$ & 2011 \\
\hline
\end{tabular}




\begin{tabular}{|c|c|c|}
\hline $\begin{array}{l}\text { Mudanças na forma de organização do ensino fundamental: } \\
\text { um estudo no município de Dois Vizinhos - PR. }\end{array}$ & $\begin{array}{l}\text { Rosangela Maria Boeno } \\
\text { (BOENO, R. M.) }\end{array}$ & 2011 \\
\hline $\begin{array}{l}\text { A inclusão da criança de seis anos no ensino fundamental: } \\
\text { narrativas de práticas curriculares não instituídas. }\end{array}$ & $\begin{array}{l}\text { Celisa Carrara Bonamigo } \\
\text { (BONAMIGO, C. C.) }\end{array}$ & 2010 \\
\hline $\begin{array}{l}\text { Ensino fundamental de nove anos e possíveis implicações no } \\
\text { processo de alfabetização: um estudo de caso. }\end{array}$ & $\begin{array}{l}\text { Melissa de Oliveira Machado } \\
\text { Brandão } \\
\text { (BRANDÃO, M. O. M.) }\end{array}$ & 2012 \\
\hline $\begin{array}{l}\text { Ensino fundamental de nove anos: implementação e } \\
\text { organização escolar em Dourados/MS. }\end{array}$ & $\begin{array}{l}\text { Mara Lucinéia Marques Corrêa } \\
\text { Bueno } \\
\text { (BUENO, M. L. M. C.) }\end{array}$ & 2011 \\
\hline $\begin{array}{l}\text { Sentidos e significados produzidos pelo professor sobre o } \\
\text { ensino fundamental de nove anos. }\end{array}$ & $\begin{array}{l}\text { Alessandra de Oliveira Capuchinho } \\
\text { (CAPUCHINHO, A. O.) }\end{array}$ & 2008 \\
\hline $\begin{array}{l}\text { Caminhos da alfabetização em Minas Gerais: Um olhar } \\
\text { etnográfico para o ciclo inicial de alfabetização. }\end{array}$ & $\begin{array}{l}\text { Flávia Helena Pontes Carneiro } \\
\text { (CARNEIRO, F. H. P.) }\end{array}$ & 2006 \\
\hline $\begin{array}{l}\text { Implementação do Ensino Fundamental de Nove Anos em } \\
\text { uma Escola Municipal de Salvador: processo participativo ou } \\
\text { força da lei? }\end{array}$ & $\begin{array}{l}\text { Suellen da Silva Chaves } \\
\text { (CHAVES, S. S.) }\end{array}$ & 2012 \\
\hline $\begin{array}{l}\text { "Vamos brincar?": continuidades e rupturas nas práticas } \\
\text { curriculares da educação infantil e dos anos iniciais do ensino } \\
\text { fundamental. }\end{array}$ & $\begin{array}{l}\text { Renata Cleiton Piacesi Corrêa } \\
\text { (CORRÊA, R. C. P.) }\end{array}$ & 2011 \\
\hline $\begin{array}{l}\text { Ensino fundamental de nove anos no Distrito Federal: } \\
\text { reflexões sobre a inserção de crianças de seis anos no ensino } \\
\text { público e a atuação docente. }\end{array}$ & $\begin{array}{l}\text { Angélica Guedes Dantas } \\
\text { (DANTAS, A. G.) }\end{array}$ & 2009 \\
\hline $\begin{array}{l}\text { A inclusão de crianças de } 6 \text { anos no Ensino Fundamental: } \\
\text { Um estudo do brincar à luz das Políticas Públicas de } \\
\text { Educação. }\end{array}$ & $\begin{array}{l}\text { Andréa Soares Delfin } \\
\text { (DELFIN, A. S.) }\end{array}$ & 2012 \\
\hline $\begin{array}{l}\text { A alfabetização e a implantação do ensino fundamental de } \\
\text { nove anos no município de Jaguarão/RS. }\end{array}$ & $\begin{array}{l}\text { Darlise Nunes Ferreira } \\
\text { (FERREIRA, D. N.) }\end{array}$ & 2011 \\
\hline $\begin{array}{l}\text { A escola de } 9 \text { anos, características e impactos por meio de } \\
\text { representações parentais: um estudo da rede municipal de } \\
\text { ensino de Araraquara. }\end{array}$ & $\begin{array}{l}\text { Valéria Longobardo Fontes } \\
\text { (FONTES, V. L.) }\end{array}$ & 2009 \\
\hline $\begin{array}{l}\text { A infância no processo de reorganização curricular do ensino } \\
\text { fundamental de nove anos na escola: um estudo de caso. }\end{array}$ & $\begin{array}{l}\text { Mônica Teresinha Colsani Furtado } \\
\text { (FURTADO, M. T. C.) }\end{array}$ & 2009 \\
\hline $\begin{array}{l}\text { Uma criança pequena em uma escola de grandes: sentimentos } \\
\text { e emoções no ingresso do ensino fundamental de nove anos. }\end{array}$ & $\begin{array}{l}\text { Yuska Natasha Bezerra Felício } \\
\text { Garcia } \\
\text { (GARCIA, Y. N. B. F.) }\end{array}$ & 2012 \\
\hline $\begin{array}{l}\text { Implementação de Políticas Públicas: um estudo de caso } \\
\text { sobre a ampliação do ensino fundamental para nove anos no } \\
\text { município de São Bernardo do Campo. }\end{array}$ & $\begin{array}{l}\text { Lara Gonzalez Gil } \\
\text { (GIL, L. G.) }\end{array}$ & 2012 \\
\hline $\begin{array}{l}\text { Ensino fundamental de nove anos no município de São } \\
\text { Paulo: um estudo de caso. }\end{array}$ & $\begin{array}{l}\text { Sylvie Bonifacio Klein. } \\
\text { (KLEIN, S. B.) }\end{array}$ & 2011 \\
\hline $\begin{array}{l}\text { Ensino fundamental de } 9 \text { (nove) anos: a universalização do } \\
\text { acesso, a permanência qualitativa na escola e as contradições } \\
\text { do processo de implantação em São Luís }\end{array}$ & $\begin{array}{l}\text { Maria do Perpétuo Socorro Lima } \\
\text { Leal } \\
\text { (LEAL, M. P. S. L.) }\end{array}$ & 2011 \\
\hline $\begin{array}{l}\text { Formação de professores na implantação do ensino } \\
\text { fundamental de nove anos: a escola um espaço de diálogo? }\end{array}$ & $\begin{array}{l}\text { Maria do Carmo Jürgensen } \\
\text { Lencioni } \\
\text { (LENCIONI, M. C. J.) }\end{array}$ & 2012 \\
\hline $\begin{array}{l}\text { Ensino fundamental de nove anos: repercussões da lei }{ }^{\circ} \\
11.274 / 2006 \text { na proposta curricular da rede municipal de }\end{array}$ & $\begin{array}{l}\text { Lilian Aparecida Lima } \\
\text { (LIMA, L. A.) }\end{array}$ & 2011 \\
\hline
\end{tabular}




\begin{tabular}{|c|c|c|}
\hline ensino de Juiz de Fora. & & \\
\hline $\begin{array}{l}\text { O ensino fundamental de nove anos e o colégio de aplicação: } \\
\text { da "prontidão" a emergência da infância. }\end{array}$ & $\begin{array}{l}\text { Carla Cristiane Loureiro } \\
\text { (LOUREIRO, C. C.) }\end{array}$ & 2010 \\
\hline $\begin{array}{l}\text { O ensino fundamental de nove anos: reflexões sobre o } \\
\text { currículo e a prática pedagógica. }\end{array}$ & $\begin{array}{l}\text { Maísa Malta } \\
\text { (MALTA, M.) }\end{array}$ & 2012 \\
\hline $\begin{array}{l}\text { A criança de seis anos na escola: transição da atividade } \\
\text { lúdica para a atividade de estudo. }\end{array}$ & $\begin{array}{l}\text { Ágatha Marine Pontes Marega } \\
\text { (MAREGA, A. M. P.) }\end{array}$ & 2010 \\
\hline $\begin{array}{l}\text { Letramento e alfabetização: resgate do papel do professor no } \\
\text { ato de aprender e ensinar. }\end{array}$ & $\begin{array}{l}\text { Ana Paula Araujo Dini de Miranda } \\
\text { (MIRANDA, A. P. A. D. de) }\end{array}$ & 2012 \\
\hline $\begin{array}{l}\text { Ampliação do ensino fundamental: compreendendo o fazer } \\
\text { do professor. }\end{array}$ & $\begin{array}{l}\text { Carolina Caires Motta } \\
\text { (MOTTA, C. C.) }\end{array}$ & 2009 \\
\hline $\begin{array}{l}\text { A criança de seis anos de idade no ensino fundamental: } \\
\text { práticas e perspectivas. }\end{array}$ & $\begin{array}{l}\text { Doris de Jesus Lucas Moya } \\
\text { (MOYA, D. J. L.) }\end{array}$ & 2009 \\
\hline $\begin{array}{l}\text { A implantação do ensino fundamental de nove anos no } \\
\text { Estado do Paraná. }\end{array}$ & $\begin{array}{l}\text { Delvana Lúcia de Oliveira } \\
\text { (OLIVEIRA, D. L.) }\end{array}$ & 2009 \\
\hline $\begin{array}{l}\text { A formação continuada de professores de primeiro ano do } \\
\text { ensino fundamental de nove anos e os desafios ao trabalho } \\
\text { pedagógico. }\end{array}$ & $\begin{array}{l}\text { Daniele Ramos de Oliveira } \\
\text { (OLIVEIRA, D. R. de) }\end{array}$ & 2011 \\
\hline $\begin{array}{l}\text { Um ano mais cedo ou um ano a mais: representação social de } \\
\text { referencial curricular para os professores alfabetizadores no } \\
\text { ensino fundamental ampliado. }\end{array}$ & $\begin{array}{l}\text { Rosane Fronza Purim } \\
\text { (PURIM, R. F.) }\end{array}$ & 2010 \\
\hline $\begin{array}{l}\text { Um retrato do primeiro ano do ensino fundamental: o que } \\
\text { revelam crianças, pais e professoras. }\end{array}$ & $\begin{array}{l}\text { Caroline Raniro } \\
\text { (RANIRO, C.) }\end{array}$ & 2009 \\
\hline $\begin{array}{l}\text { O currículo do ciclo inicial de alfabetização de minas gerais: } \\
\text { inovação ou continuidade? - Uma análise da proposta } \\
\text { curricular do ciclo inicial de alfabetização da Rede Pública } \\
\text { Estadual de Minas Gerais }\end{array}$ & $\begin{array}{l}\text { Viviane Raquel Ribeiro } \\
\text { (RIBEIRO, V. R.) }\end{array}$ & 2008 \\
\hline $\begin{array}{l}\text { O Ensino Fundamental de nove anos no estado de Alagoas: } \\
\text { Um estudo da efetivação da política de implantação a partir } \\
\text { da experiência do Município de Delmiro Gouveia - AL. }\end{array}$ & $\begin{array}{l}\text { Idnelma Lima da Rocha } \\
\text { (ROCHA, I. L. da) }\end{array}$ & 2012 \\
\hline $\begin{array}{l}\text { Políticas municipais de educação infantil: desafios à gestão } \\
\text { local a partir da implantação do ensino fundamental de nove } \\
\text { anos }\end{array}$ & $\begin{array}{l}\text { Marcia Maria Rosa } \\
\text { (ROSA, M. M.) }\end{array}$ & 2011 \\
\hline $\begin{array}{l}\text { Ensino fundamental de nove anos: dimensões políticas e } \\
\text { pedagógicas. }\end{array}$ & $\begin{array}{l}\text { Andréia Manosso Samways } \\
\text { (SAMWAYS, A. M.) }\end{array}$ & 2012 \\
\hline Linguagem e infância: relações com o letramento. & $\begin{array}{l}\text { Carla Melissa Klock Scalzitti } \\
\text { (SCALZITTI, C. M. K.) }\end{array}$ & 2012 \\
\hline $\begin{array}{l}\text { Entre a educação infantil e o ensino fundamental: uma } \\
\text { análise das vivências espaço-temporais das infâncias. }\end{array}$ & $\begin{array}{l}\text { Lenir Luft Schmitz } \\
\text { (SCHMITZ, L. L.) }\end{array}$ & 2008 \\
\hline $\begin{array}{l}\text { Construção dos conteúdos para o primeiro ano do Ensino } \\
\text { Fundamental de nove anos a partir da base de conhecimento } \\
\text { sobre a língua materna de professoras em exercício e de } \\
\text { propostas governamentais. }\end{array}$ & $\begin{array}{l}\text { Danitza Dianderas da Silva } \\
\text { (SILVA, D. D.) }\end{array}$ & 2008 \\
\hline $\begin{array}{l}\text { A dimensão complexa das políticas públicas para a educação: } \\
\text { o ensino fundamental de nove anos. }\end{array}$ & $\begin{array}{l}\text { Paulo Alves da Silva } \\
\text { (SILVA, P. A.) }\end{array}$ & 2012 \\
\hline $\begin{array}{l}\text { A implementação do ensino fundamental de nove anos e seus } \\
\text { efeitos pára a educação infantil: um estudo em municípios } \\
\text { catarinenses. }\end{array}$ & $\begin{array}{l}\text { Rute da Silva } \\
\text { (SILVA, R.) }\end{array}$ & 2009 \\
\hline
\end{tabular}




\begin{tabular}{|l|l|c|}
\hline $\begin{array}{l}\text { A aprendizagem e a prática pedagógica no } 1^{\circ} \text { ano do ensino } \\
\text { fundamental. }\end{array}$ & $\begin{array}{l}\text { Thalita Folmann da Silva } \\
\text { (SILVA, T. F.) }\end{array}$ & 2010 \\
\hline $\begin{array}{l}\text { A reorganização do ensino fundamental de nove anos a partir } \\
\text { do projeto político pedagógico das escolas. }\end{array}$ & $\begin{array}{l}\text { Kellcia Rezende Souza } \\
\text { (SOUZA, K. R.) }\end{array}$ & 2012 \\
\hline $\begin{array}{l}\text { O ensino fundamental de nove anos: o que revelam } \\
\text { professores em seus discursos. }\end{array}$ & $\begin{array}{l}\text { Fernanda Sturion } \\
\text { (STURION, F.) }\end{array}$ & 2010 \\
\hline $\begin{array}{l}\text { Alfabetizar, Letrar - Práticas alfabetizadoras no contexto da } \\
\text { escola organizada em ciclos. }\end{array}$ & $\begin{array}{l}\text { Danieli Sebastiana Oliveira Tasca } \\
\text { (TASCA, D. S. O.) }\end{array}$ & 2010 \\
\hline $\begin{array}{l}\text { Ensino Fundamental de Nove Anos: dificuldades enfrentadas } \\
\text { e aprendizados construídos por gestores e professores. }\end{array}$ & $\begin{array}{l}\text { Andréa Cristine Mesquita } \\
\text { Bergamasco Thomé } \\
\text { (THOMÉ, A. C. M. B.) }\end{array}$ & 2011 \\
\hline $\begin{array}{l}\text { Educação continuada e trabalho docente no bloco inicial de } \\
\text { alfabetização: o caso de uma escola da rede pública do } \\
\text { Distrito Federal. }\end{array}$ & $\begin{array}{l}\text { Maria Antonia Honorio Tolentino } \\
\text { (TOLENTINO, M. A. H.) }\end{array}$ & 2007 \\
\hline $\begin{array}{l}\text { Professoras alfabetizadoras e o ensino fundamental de nove } \\
\text { anos: concepções frente à infância e à ludicidade. }\end{array}$ & $\begin{array}{l}\text { Jamily Charão Vargas } \\
\text { (VARGAS, J. C.) }\end{array}$ & 2010 \\
\hline $\begin{array}{l}\text { Ensino fundamental de 09 anos: implicações na formação do } \\
\text { professor para o atendimento à infância. }\end{array}$ & $\begin{array}{l}\text { Alexandra Tagata Zatti } \\
\text { (ZATTI, A. T.) }\end{array}$ & 2009 \\
\hline
\end{tabular}

ARTIGOS:

\begin{tabular}{|l|l|c|}
\hline \multicolumn{1}{|c|}{ Título do trabalho } & \multicolumn{1}{|c|}{ Nome do(s) autor(es) } & Ano \\
\hline $\begin{array}{l}\text { O ensino fundamental de nove anos e o direito à } \\
\text { educação }\end{array}$ & $\begin{array}{l}\text { ARELARO, Lisete Regina G.; } \\
\text { JACOMINI, Márcia Aparecida; } \\
\text { KLEIN, Sylvie Bonifácio. }\end{array}$ & 2011 \\
\hline $\begin{array}{l}\text { Ampliação do Ensino Fundamental para nove anos: entre } \\
\text { as normatizações da política educacional, o movimento } \\
\text { teórico e as representações sociais dos profissionais da } \\
\text { escola pública. }\end{array}$ & $\begin{array}{l}\text { ABDIAN, Graziela Zambão; } \\
\text { CIARDELLA, Thaís Monteiro; }\end{array}$ & 2011 \\
\hline $\begin{array}{l}\text { Ensino Fundamental de nove anos: ampliação da } \\
\text { permanência e qualidade de ensino }\end{array}$ & ALMEIDA, Julio Gomes & 2011 \\
\hline $\begin{array}{l}\text { Educação infantil e ensino fundamental: desafios e } \\
\text { desencontros na implantação de uma nova política }\end{array}$ & CORREA, Bianca Cristina & 2011 \\
\hline $\begin{array}{l}\text { Os alfabetizados-desviantes ou sobre a educação dos 6 } \\
\text { anos }\end{array}$ & DORNELLES, Leni Vieira & 2011 \\
\hline $\begin{array}{l}\text { Ensino Fundamental de 9 anos: estamos preparados para } \\
\text { implantá-lo? }\end{array}$ & GORNI, Doralice Aparecida Paranzini. \\
\hline $\begin{array}{l}\text { Alfabetização e letramento no cenário escolar: } \\
\text { compreensões de gestores educacionais }\end{array}$ & $\begin{array}{l}\text { HEINIG, Otilia Lizete de Oliveira } \\
\text { Martins }\end{array}$ & 2007 \\
\hline $\begin{array}{l}\text { Direito, qualidade e gestão da educação no ensino } \\
\text { fundamental de nove anos na rede municipal de Diadema }\end{array}$ & $\begin{array}{l}\text { JACOMINI, Márcia Aparecida; } \\
\text { ROSA, Carla de Oliveira; } \\
\text { ALENCAR, Felipe Willian Ferreira de. }\end{array}$ & 2012 \\
\hline $\begin{array}{l}\text { Jogo e letramento: crianças de } 6 \text { anos no ensino } \\
\text { fundamental }\end{array}$ & $\begin{array}{l}\text { KISHIMOTO, Tizuko Morchida; } \\
\text { PINAZZA, Mônica Appezzato; } \\
\text { MORGADO, Rosana de Fátima } \\
\text { Cardoso; } \\
\text { TOYOFUKI, Kamila Rumi. }\end{array}$ & 2011 \\
\hline
\end{tabular}




\begin{tabular}{|l|l|c|}
\hline $\begin{array}{l}\text { Ensino Fundamental de nove anos: um estudo da } \\
\text { percepção das equipes de direção de escolas públicas de } \\
\text { um município do Estado de São Paulo }\end{array}$ & $\begin{array}{l}\text { MAIA, Graziela Zambão Abdian; } \\
\text { CAMILLO, Cláudia Vieira. }\end{array}$ & 2009 \\
\hline $\begin{array}{l}\text { Ensino fundamental de 9 anos: o que dizem os } \\
\text { professores do 1o ano }\end{array}$ & MORO, Catarina de Souza. \\
\hline $\begin{array}{l}\text { Trabalho docente e desenvolvimento das atividades } \\
\text { simbólicas: considerações para o ensino fundamental de } \\
\text { nove anos }\end{array}$ & $\begin{array}{l}\text { NOGUEIRA, Ana Lúcia Horta; } \\
\text { CATANANTE, Ingrid Thais. }\end{array}$ & 2009 \\
\hline $\begin{array}{l}\text { Infância e crianças de } 6 \text { anos: desafios das transições na } \\
\text { educação infantil e no ensino fundamental }\end{array}$ & $\begin{array}{l}\text { PANSINI, Flávia; } \\
\text { MARIN, Aline Paula. }\end{array}$ & 2011 \\
\hline $\begin{array}{l}\text { A atividade lúdica, a criança de } 6 \text { anos e o ensino } \\
\text { fundamental }\end{array}$ & $\begin{array}{l}\text { ROCHA, Maria Silvia Pinto de Moura } \\
\text { Librandi da. }\end{array}$ & 2009 \\
\hline $\begin{array}{l}\text { "Parece um prezinho": famílias de classes populares e o } \\
\text { novo ensino fundamental }\end{array}$ & $\begin{array}{l}\text { ROCHA, Maria Silvia Pinto de Moura } \\
\text { Librandi da. }\end{array}$ & 2010 \\
\hline $\begin{array}{l}\text { A escola de nove anos e a atuação docente: análise de } \\
\text { uma experiência na escola pública. }\end{array}$ & $\begin{array}{l}\text { SANT'ANA, Izabella Mendes; } \\
\text { GUZZO, Raquel Souza Lobo. }\end{array}$ & 2009 \\
\hline $\begin{array}{l}\text { A prática docente no 1 } \text { ano do ensino fundamental e o } \\
\text { ensino de ciências: um estudo de caso. }\end{array}$ & $\begin{array}{l}\text { TOSCANO, Carlos; } \\
\text { SAITO, Heloisa Toshie Irie. }\end{array}$ & 2009 \\
\hline
\end{tabular}

\section{ARTIGOS DA ANPED:}

\begin{tabular}{|l|l|c|}
\hline \multicolumn{1}{|c|}{ Título do trabalho } & \multicolumn{1}{|c|}{ Nome do(s) autor(es) } & Ano \\
\hline A criança de seis anos e o ensino fundamental. & AGUIAR, Maria Aparecida Lapa de. & 2012 \\
\hline $\begin{array}{l}\text { Ampliação da escolaridade obrigatória: alfabetização e } \\
\text { letramento com crianças de seis anos no ensino } \\
\text { fundamental. }\end{array}$ & ALMEIDA, Ana Caroline de & 2012 \\
\hline $\begin{array}{l}\text { Ensino fundamental de nove anos: análise de uma } \\
\text { experiência no interior do estado de São Paulo. }\end{array}$ & CORREA, Bianca Cristina & 2010 \\
\hline $\begin{array}{l}\text { A implantação do ensino fundamental de nove anos em } \\
\text { escolas municipais de Campinas/SP: o olhar dos } \\
\text { gestores. }\end{array}$ & MACHADO, Vera Lúcia de Carvalho & 2010 \\
\hline $\begin{array}{l}\text { O ensino fundamental de nove anos como política de } \\
\text { integração social: análises a partir de dois estados } \\
\text { brasileiros. }\end{array}$ & $\begin{array}{l}\text { SILVA, Antonia Almeida; } \\
\text { SCAFF, Elisângela Alves da Silva }\end{array}$ & 2009 \\
\hline
\end{tabular}

\footnotetext{
${ }^{8}$ Este trabalho foi encontrado como artigo (resumo de tese) no levantamento da Capes, porém, optou-se pela busca online do trabalho completo para sua análise. Sendo assim, nas referências encontra-se a referência à tese completa, e não ao artigo.
} 
ANEXO 5

Roteiro de leitura preenchido com informações dos trabalhos analisados

\begin{tabular}{|c|c|c|c|c|}
\hline Autor; ano & Local de Coleta de dados & $\begin{array}{l}\text { Instrumentos de } \\
\text { coleta de dados }\end{array}$ & Participantes & Abrangência do estudo \\
\hline BEZERRA, D. R. S., 2011 & Estado de São Paulo & Obs+Entrev & Prof+Diretoria & 1 esc mun, 9 profs, 1 diretor, 1 coord. Pedg. \\
\hline COSTA, S. S., 2009 & Goiânia (GO) & Observação & ------------------ & $\begin{array}{l}1 \text { EMEF; entrev. c/ diretor, } 3 \text { coord. Pedag., } 3 \text { profs de 10 ano, } 2 \\
\text { servidores, } 2 \text { familiares, e entrev em grupo c/ } 48 \text { alunos de } 10 \text { ano. }\end{array}$ \\
\hline FURTADO, M. T. C, 2009. & Itajaí (SC) & Obs+Entrev & Professores & 14 profs entrevistados \\
\hline LEAL, M. S. P. L., 2011 & São Luís (MA) & Questionário & Prof+SME & $\begin{array}{l}4 \text { profs e outros 11, entre coordenadores, dirigente, formador de } \\
\text { professores, ex-superintendente da rede municipal }\end{array}$ \\
\hline LIMA, L. A., 2011 & Juiz de For a (MG) & Obs+Entrev & Prof+Dir & 6 escolas, entrev c/ 2 profs, 6 coord, 1 diretora e 1 vice-diretora \\
\hline PURIM, R. F., 2010 & Timbó (SC) & Obs+Quest & Prof+Dir & Rede Munic; Quest c/ 10 profs e 5 coord.; Obs do curso de formação \\
\hline SILVA, R., 2009 & $\begin{array}{l}\text { Joinvile, Palhoça, Indaial, } \\
\text { Bom Retiro, Rio fortuna, } \\
\text { Santo Amaro da Imperatriz, } \\
\text { Tubarão, Blumenau, } \\
\text { Florianópolis (todos em SC). }\end{array}$ & Quest+Entrev & SME/NRE & Quest enviado a nove SMEs \\
\hline TENREIRO, M. O. V., 2011 & Ponta Grossa (PR) & Entrevista & Prof+Dir & Entrev c/ diretor, pedagogo e 2 prof de cada escola, em 8 escolas \\
\hline CAPUCHINHO, A. O., 2007 & Grande SP & Quest+Entrev & Professores & Quest e entrev c/ 9 profs da rede municipal \\
\hline OLIVEIRA, D. L., 2009 & $\begin{array}{l}\text { Nove municípios diferentes } \\
\text { do Paraná }\end{array}$ & Entrevista & Outros & $\begin{array}{l}\text { Entrev c/ } 2 \text { técnicos da SEE, } 2 \text { conselheiros do CEE, presidente da } \\
\text { UNDIME, coord regional da SINEPE, presidente da Comissão de } \\
\text { Educação da Assembleia Legislativa e promotor. }\end{array}$ \\
\hline SAMWAYS, A. M., 2012 & Ponta Grossa (PR) & Obs+Quest & Prof+Dir & $\begin{array}{l}1 \text { escola privada, } 2 \text { EM (El e 10 ciclo de EF). Entrev c/ } 2 \text { diretores, } 4 \\
\text { pedagogos e } 5 \text { profs. }\end{array}$ \\
\hline BONAMIGO, C. C., 2010 & Várzea Paulista (SP) & Outros & Professores & Entrev c/ 15 profs, de 15 escolas diferentes da rede municipal. \\
\hline SILVA, D. D. , 2008 & São Carlos (SP) & Entrevista & Professores & $\begin{array}{l}\text { Entrev c/ } 10 \text { profs de rede privada e pública; depois realização de } \\
\text { grupo de discussão com outras } 5 \text { profs. }\end{array}$ \\
\hline MIRANDA, A. P. A. D., 2012 & $\begin{array}{l}\text { Osasco, Taboão da Serra e } \\
\text { São Paulo (todos de SP) }\end{array}$ & Questionário & Professores & Quest c/ 16 profs: 8 da rede pública e 8 da privada. \\
\hline FONTES, V. L., 2009 & Araraquara (SP) & Entrevista & Pais/familiares & Entrev c/ 56 pais de 2 turmas de $1^{\circ}$ ano de 2 escolas municipais \\
\hline ANTUNES, J., 2010 & Santa Maria (RS) & Entrevista & Prof+Dir & 2 escolas ( 1 estadual e 1 particular) \\
\hline BRANDÃO, M. O. M., 2012 & Porto Alegre (RS) & Obs+Entrev & Professores & $1 \mathrm{EEEF}, 1$ prof, obs de 1 turma de 10 ano \\
\hline DELFIN, A. S., 2012 & São Paulo capital & Obs+Quest & Professores & quest c/ 13 profs de escola part., obs de 1 turma de 10 ano \\
\hline HASHIMOTO, C. I. , 2012 & Interior de SP & Obs+Entrev & Prof+Dir & 4 EM e 1 particular, entrevista c/ 4 profs e 3 gestores \\
\hline KLEIN, S. B., 2011 & São Paulo capital & Obs+Entrev & Prof+Dir+Alunos+Pais & Obs em 1 turma de 10 ano, uma EM \\
\hline LENCIONI, M. C. J., 2012 & Limeira (SP) & Observação & ------------- & Obs do HTPC em 1 escola municipal \\
\hline
\end{tabular}




\begin{tabular}{|c|c|c|c|c|}
\hline MORAES, A. C. M., 2012 & São Carlos (SP) & Quest+Entrev & Prof+Dir & 5 coor pedag e 18 profs, de 5 diferentes escolas da rede municipal \\
\hline SILVA, J. S., 2011 & Lajeado (RS) & Obs+Entrev & Professores & Entrev c/ 1 prof de escola particular, obs com 1 turma de 1ㅇa. \\
\hline ABREU, M. M. O., 2009 & Uberlândia (MG) & Obs+Quest+Entrev & Outros & $\begin{array}{l}1 \text { EM, obs em } 3 \text { turmas: } 10,2^{\circ} \text { e } 30 \text { ano, entrev } \mathrm{c} / \text { os alunos, quest } \mathrm{c} / \\
3 \text { profs e com } 1 \text { agente do CEMEPE }\end{array}$ \\
\hline ARAÚJO, R. C. B. F., 2008 & Juiz de For a (MG) & Obs+Entrev & Professores & Entrev c/ 4 profs de 1ㅇa ano de 1 EMEF e 1 EMEI. \\
\hline ZINGARELLI, J. E. B., 2009 & Araraquara (SP) & Observação & --------------- & Obs em 2 escolas privadas e 2 da rede municipal \\
\hline BUENO, M. L. M. C., 2010 & Dourados (MS) & Entrevista & Dir+SME & 3 escolas municipais; entrev c/ 3 coord. Pedag. e 1 técnino da SME \\
\hline DANTAS, A. G., 2009 & Distrito Federal & Obs+Entrev & Professores & 2 escolas municipais; obs em 2 turmas de 10 ano e entrev $\mathrm{c} / 2$ profs \\
\hline CORRÊA, R. C. P., 2011 & Itajaí (SC) & Outros & --------------- & Registro das atividades dos alunos de 5 e 6 anos (El e EF) de 1escola. \\
\hline TASCA, D. S. O., 2010 & Campinas (SP) & Outros & Professores & Entrev c/ 4 profs da rede municipal \\
\hline CARNEIRO, F. H. P., 2006 & Belo Horizonte (MG) & Obs+Entrev & Prof+SME & Entrev c/ 1 prof, 1 superv, 1 diret, e 1 funcionária da SEE-MG \\
\hline BARBOSA, M. S., 2009 & Interior do estado de MS & Obs+Entrev & Prof+Dir+Alunos & 1 diretora, 2 profs e obs durante um ano em duas turmas de $1^{\circ}$ ano. \\
\hline TOLENTINO, M. A. H., 2007 & Distrito Federal & Obs+Entrev & Prof+Dir+SME & 2 profs, 2 coord pedag e 1 membro da Diretoria Regional de Ensino \\
\hline NOGUEIRA, G. M., 2011 & Pelotas (RS) & Obs+Entrev & Prof+Dir+SME+Alunos & $\begin{array}{l}\text { Analisou planejamento, diario de classe e caderno dos alunos de } 1 \\
\text { turma de pré-escola e } 1 \text { turma de } 10 \text { ano. Entrev c/: } 1 \text { membro da } \\
\text { SME, } 1 \text { coord pedag, } 5 \text { profs, e } 5 \text { crianças (em } 2 \text { entrev coletivas). }\end{array}$ \\
\hline MARCONDES, K. H. B., 2012 & Interior de SP & Obs+Entrev & Prof+Alunos+Pais & $\begin{array}{l}\text { Acompanhou transição de crianças da El p/ EF em } 4 \text { escolas ( } 2 \text { CER, } \\
1 \text { EMEF e } 1 \text { EEEF). Entrev c/ } 13 \text { crianças, } 13 \text { famílias, } 4 \text { profs de El e } 6 \\
\text { profs de EF. }\end{array}$ \\
\hline MASCIOLI, S. A. Z., 2012 & Araraquara (SP) & Obs+Entrev & Outros & $\begin{array}{l}\text { Obs em } 1 \text { CER e } 1 \text { EMEF. Entrev c/ 1diretor, } 2 \text { prof e a merendeira } \\
\text { na CER; e entrev c/ } 1 \text { diretor, 1coord pedag, } 3 \text { profs e } 1 \text { merendeira } \\
\text { na EMEF. }\end{array}$ \\
\hline RANIRO, C., 2009 & São Carlos (SP) & Obs+Entrev & Prof+Alunos+Pais & 3 profs de 10 ano de uma EMEF, 15 alunos e 15 pais. \\
\hline OLIVEIRA, D. R. de, 2011 & Marília (SP) & Quest+Entrev & Prof+Dir+SME & $\begin{array}{l}\text { Quest c/ } 47 \text { profs de 10 anos e } 9 \text { coord escolar; entrev c/ } 4 \text { profs e } 1 \\
\text { gestor da SME }\end{array}$ \\
\hline MOYA, D. J. L., 2009 & Estado do Paraná & Entrevista & Prof+Dir+SME & $\begin{array}{l}2 \text { membros da SME, } 2 \text { diretores, } 2 \text { coord. Pedag, e } 4 \text { profs de } 2 \\
\text { escolas municipais ( } 1 \text { prof de uma, } 3 \text { profs de outra) }\end{array}$ \\
\hline ROCHA, I. L. da, 2012 & Delmiro Gouveia (AL) & Entrevista & Prof+Pais & $\begin{array}{l}6 \text { profs de } 10 \text { ano, } 9 \text { mães de alunos do } 20 \text { ao } 50 \text { ano, em } 3 \text { escolas, } \\
\text { uma estadual e duas municipais }\end{array}$ \\
\hline VARGAS, J. C., 2010 & São Sepé (RS) & Entrevista & Professores & Entrev c/ 3 profs de 10 ano. \\
\hline SOUZA, K. R., 2012 & Dourados (MS) & Obs+Entrev & Prof+Dir+SME & 2 profs, 2 coord de 2 escolas municipais; e 2 técnicos da SME \\
\hline GIL, L. G., 2012 & São Bernardo (SP) & Obs+Entrev & Outros & $\begin{array}{l}\text { Entrev c/ Secretária da SME, entrev c/ } 2 \text { profs, } 1 \text { diretora, } 3 \\
\text { membros do conselho da escola, } 9 \text { pais e } 17 \text { alunos de } 1 \text { EM. }\end{array}$ \\
\hline ROSA, M. M., 2011 & $\begin{array}{l}\text { Frederico Westphalen, } \\
\text { Chapecó, Pato Branco (RS) }\end{array}$ & Quest+Entrev & Prof+SME & $\begin{array}{l}\text { Quest a SME dos } 3 \text { municípios; entrev c/ os dirigentes municipais e } 1 \\
\text { profissional da El. }\end{array}$ \\
\hline CHAVES, S. S., 2012 & Salvador (BA) & Entrevista & Prof+Dir+Pais & 1 diretora, 1 coord pedag, 1 prof, e 1 mãe do conselho eescolar \\
\hline MAREGA, A. M. P., 2010 & Maringá (PR) & Observação & - -------------- & 1 turma de 10 ano de 1 escola municipal \\
\hline ZATTI, A. T., 2009 & Chapecó (SC) & Observação & ------------------ & 1 escola \\
\hline
\end{tabular}




\begin{tabular}{|c|c|c|c|c|}
\hline AMARAL, A. C. T., 2008 & Curitiba (PR) & Observação & ------------------ & Obs de 1 turma de 10 ano de 1 EMEF. \\
\hline LOUREIRO, C. C., 2010 & Florianópolis (SC) & Obs+Quest & Prof+Dir & Diretores do Colégio de Aplicação e professoras estagiárias. \\
\hline MOTTA, C. C., 2009 & Assis (SP) & Obs+Entrev & Professores & 3 profs de 10 ano em uma escola de EMEIF (pré-escola e 1ㅇano) \\
\hline FERREIRA, D. N., 2011 & Jaguarão (RS) & Entrevista & Professores & 3 profs alfabetizadoras do EF8 e EF9. \\
\hline STURION, F., 2010 & Interior de SP & Entrevista & Prof+Dir & 4 supervisoras e 3 professoras de 2 escolas diferentes. \\
\hline SCHMITZ, L. L., 2008 & Estado de Santa Catarina & Observação & ------------------- & Obs. de uma turma de pré e de 10 ano de uma escola municipal \\
\hline ABREU, L. P., 2010 & Interior de Pernambuco & Outros & Alunos & 3 crianças de 1 o ano de uma escola municipal \\
\hline MALTA, M., 2012 & Interior de SP & Entrevista & Professores & 6 profs de 1 o ano de 2 escolas \\
\hline SILVA, P. A., 2012 & Brasília e Jaciara (MS) & Entrevista & SME/NRE & $\begin{array}{l}\text { Coordenadora-Geral do EF do ME e } 2 \text { secretários municipais de } \\
\text { Jaciara (MS), o atual e o anterior, e } 14 \text { profs. }\end{array}$ \\
\hline BOENO, R. M., 2011 & Dois Vizinhos (PR) & Entrevista & Prof+Dir+SME & $\begin{array}{l}5 \text { gestores da SME, } 2 \text { coord pedag. e } 10 \text { profs, sendo } 2 \text { de cada ano, } \\
\text { do } 1 \text { o ao } 5 \text { ㅇ. }\end{array}$ \\
\hline SILVA, T. F., 2010 & Curitiba (PR) & Obs+Quest+Entrev & Prof+Alunos & $\begin{array}{l}4 \text { profs: duas de uma escola privada, e duas de uma escola } \\
\text { municipal. Foram } 48 \mathrm{~h} \text { de obs, durante } 6 \text { meses. }\end{array}$ \\
\hline RIBEIRO, V. R., 2008 & Vespasiano (MG) & Questionário & Prof+Dir & 4 profs e 2 coord pedag da rede estadual \\
\hline GARCIA, Y. N. B. L. F., 2012 & Interior de SP & Obs+Entrev & Professores & Obs em 2 turmas de 10 ano, entrev c/ 4 profs de 1 escola municipal \\
\hline THOMÉ, A. C. M. B., 2011 & Interior de SP & Entrevista & Prof+Dir+SME & $\begin{array}{l}\text { Supervisora da SME, } 3 \text { coord pedag e } 3 \text { profs de } 1 \text { o ano de } 3 \text { escolas } \\
\text { municipais. }\end{array}$ \\
\hline SCALZITTI, C. M. K., 2012 & Rondonópolis (MG) & Obs+Entrev & Prof+Dir+Alunos & $\begin{array}{l}\text { Entrev com } 1 \text { coord pedag e } 1 \text { prof de } 1 \text { EMEI, estagiária de uma } \\
\text { brinquedoteca e idealizadora da creche. Obs de } 1 \text { turma de } 10 \text { ano } \\
\text { da prof entrevistada. }\end{array}$ \\
\hline $\begin{array}{l}\text { ARELARO, JACOMINI e KLEIN, } \\
2011\end{array}$ & São Paulo e Suzano (SP) & Quest+Entrev & Prof+Dir+Alunos+Pais & $\begin{array}{l}6 \text { escolas: } 2 \text { estaduais, } 3 \text { munic de SP e } 1 \text { munic de Suzano; entrev c/ } \\
57 \text { crianças, } 6 \text { gestores e } 4 \text { profs. Quest c/ } 46 \text { pais e } 59 \text { profs de } \\
\text { outros anos do EF. }\end{array}$ \\
\hline $\begin{array}{l}\text { NOGUEIRA e CATANANTE, } \\
2011\end{array}$ & Interior de SP & Entrevista & Professores & 6 professoras de 4 diferentes cidades \\
\hline PANSINI e MARIN, 2011 & Rolim de Moura (RO) & Entrevista & Prof+SME & $\begin{array}{l}8 \text { escolas estaduais; Entrev c/ } 1 \text { coord pedag da Secretaria Estadual } \\
\text { de Educação e entrev coletiva c/ } 44 \text { profs de 1으 a 30 ano. }\end{array}$ \\
\hline CORREA, B. C., 2011 & Interior de SP & Obs+Entrev & Prof+Dir+Pais & $\begin{array}{l}2 \text { EMEF e } 1 \text { EMEI; Entrev c/ } 9 \text { profs, } 3 \text { diretoras, } 1 \text { inspetor de aluno, } \\
6 \text { mães. }\end{array}$ \\
\hline ALMEIDA, J. G., 2011 & São Paulo & Obs+Quest & Dir+SME & 3 escolas munic. Quest c/ 3 gestores da escola e 3 da SME \\
\hline GORNI, D. A. P., 2007 & Interior do PR (8 cidades) & Entrevista & Prof+Dir+SME & $\begin{array}{l}\text { entrev c/ } 2 \text { responsáveis do NRE, } 8 \text { responsáveis de } 8 \mathrm{SME}, 12 \\
\text { diretores e } 12 \text { profs. }\end{array}$ \\
\hline ROCHA, M. S. P. M. L., 2010 & Interior de SP & Entrevista & Pais/familiares & Entrev c/ 58 pais de crianças de 8 turmas de $1^{\circ}$ ano de 5 escolas \\
\hline KISHIMOTO et al., 2011 & São Paulo capital & Obs+Entrev & Pais/familiares & $\begin{array}{l}\text { Acompanhou turmas de 10 ano de } 2006 \text { a 2010, entrev. c/ pais, } \\
\text { depoimentos de alunos e registros das profs; em } 1 \text { escola, a de } \\
\text { Aplicação da USP }\end{array}$ \\
\hline DORNELLES, L. V., 2011 & Porto Alegre (RS) & Observação & ----------------- & Uma turma de uma escola pública de periferia \\
\hline
\end{tabular}




\begin{tabular}{|c|c|c|c|c|}
\hline MORO, C. S., 2009 & Curitiba (PR) & Entrevista & Professores & 6 profs de 3 escolas distintas da rede municipal. \\
\hline ROCHA, M. S. P. M. L., 2009 & Interior de SP & Obs+Quest+Entrev & Prof+Pais & $\begin{array}{l}\text { Obs de } 8 \text { turmas de } 1 \text { o ano ( } 1 \text { x por semana) durante } 1 \text { ano (2006 - } \\
\text { ano de implantação), de } 5 \text { escolas municipais; Entrev c/ } 8 \text { prof das } \\
\text { turmas obs; e c/ } 58 \text { familiares desses alunos; Quest c/ } 10 \text { coord } \\
\text { pedag da El que parte das crianças obs fizeram em } 2005 \text {. }\end{array}$ \\
\hline MAIA e CAMILLO, 2009 & Marília (SP) & Entrevista & Diretoria & $\begin{array}{l}\text { diretores e vice diretores de } 6 \text { escolas munic: } 2 \text { creches, } 2 \text { EMEIs e } 2 \\
\text { EMEFs }\end{array}$ \\
\hline $\begin{array}{l}\text { JACOMINI, ROSA e ALENCAR, } \\
2012\end{array}$ & Diadema (SP) & Obs+Entrev & Outros & $\begin{array}{l}\text { Em } 1 \text { EMEF e 1EMEI, realizou entrev c/ } 43 \text { alunos de 10 ano, } 14 \text { pais, } \\
6 \text { profs, } 4 \text { gestores, } 2 \text { membros do conselho de escola, } 2 \\
\text { representantes da SME e } 1 \text { representante do Sindicato de } \\
\text { funcionários da prefeitura }\end{array}$ \\
\hline HEINIG, O. L. O. M., 2010 & 6 municípios de SC & Entrevista & SME/NRE & 6 gestores de 6 municípios \\
\hline ABDIAN e CIARDELLA, 2011 & Interior de SP & Entrevista & Diretoria & $\begin{array}{l}2 \text { diretores e } 2 \text { coord pedag de duas escolas, } 1 \text { municipal e outra } \\
\text { estadual }\end{array}$ \\
\hline SANT'ANA e GUZZO, 2009 & Interior de SP & Obs+Entrev & Professores & Obs em 1 escola pública, entrev c/ 10 profs desta escola \\
\hline TOSCANO E SAITO, 2009 & Maringá e Londrina (PR) & Entrevista & Professores & $\begin{array}{l}4 \text { profs de } 3 \text { escolas privadas, sendo } 2 \text { profs de Maringá e } 2 \text { profs de } \\
\text { Londrina }\end{array}$ \\
\hline SILVA e SCAFF, 2009 & Bahia e MS & Entrevista & Prof+Pais & Entrevistas (não fala qntos participantes) em dois estados \\
\hline MACHADO, V. L. C., 2010 & Campinas (SP) & Entrevista & Diretoria & 2 diretores e 2 coor pedag de 4 escolas da rede municipal. \\
\hline AGUIAR, M. A. L., 2012 & Região Sul & Obs+Entrev & Professores & $\begin{array}{l}\text { Obs em } 2 \text { turmas de } 10 \text { ano, entrev c/ as } 2 \text { profs dessas turmas da } \\
\text { rede municipal. Entrev c/ responsável técnico pedagogico da SME e } \\
\text { acompanhamento da formação continuada. }\end{array}$ \\
\hline ALMEIDA, A. C., 2012 & Tiradentes (MG) & Obs+Entrev & Professores & $\begin{array}{l}\text { Obs em } 1 \text { turma de } 10 \text { ano, de abril a dezembro de } 2010 \text {, } \\
\text { contabilizando } 47 \text { dias inteiros. }\end{array}$ \\
\hline CORREA, B. C., 2010 & Interior de SP & Obs+Entrev & Prof+Dir+SME+Alunos & $\begin{array}{l}\text { Obs em turma de pré e de 1ㅇan ano, entrev c/ com profs, gestores e } \\
\text { alunos }\end{array}$ \\
\hline
\end{tabular}

